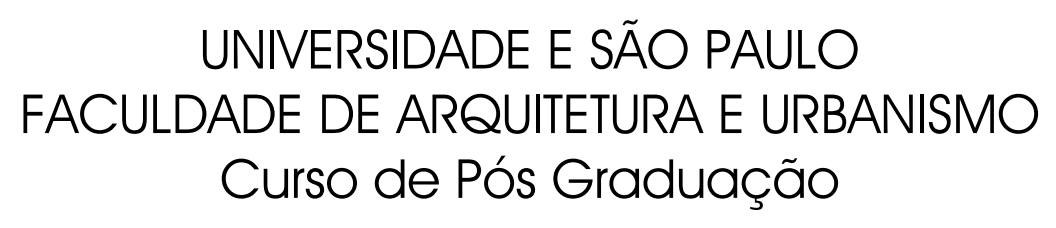

\title{
Uma Contribuição para a Avaliação da Qualidade no Dimensionamento dos Espaços da Habitação.
}

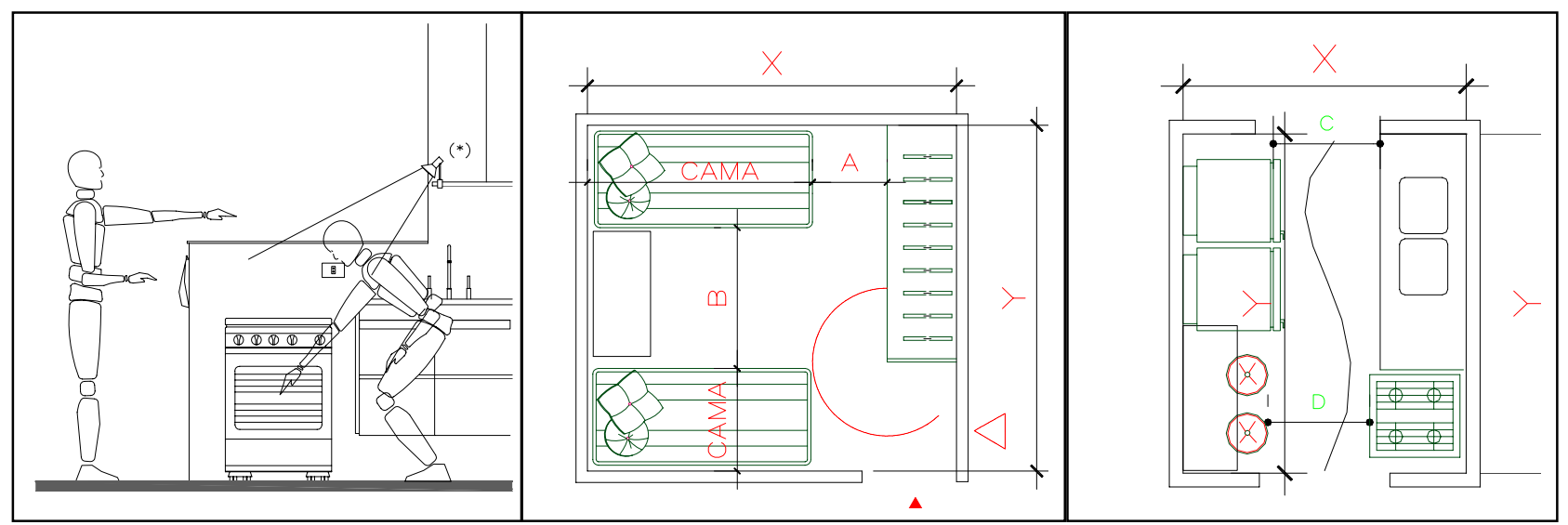

Claudia Maria Lavieri Lapetina

São Paulo 2007 


\section{UNIVERSIDADE E SÃO PAULO \\ FACULDADE DE ARQUITETURA E URBANISMO \\ Curso de Pós Graduação}

\section{Uma Contrilbuição para a Avaliação da Qualidade no Dimensionamento dos Espaços da Habitação.}

Claudia Maria Lavieri Lapetina

São Paulo

2007 
Claudia Maria Lavieri Lapetina

Uma Contribuição para a Avaliação da Qualidade no Dimensionamento dos Espaços da Habitação.

\author{
Dissertação de mestrado, \\ apresentada à Faculdade de \\ Arquitetura e Urbanismo da \\ Universidade de São Paulo, para \\ obtenção do grau de mestre. \\ Área de Concentração: \\ Tecnologia da Arquitetura \\ Orientador: Prof. Dr. Jose Jorge \\ Boueri.
}

São Paulo

2007 
AUTORIZO A REPRODUÇÃO E DIVULGAÇÃO TOTAL OU PARCIAL DESTE TRABALHO, POR QUALQUER MEIO CONVENCIONAL OU ELETRÔNICO,

PARA FINS DE ESTUDO E PESQUISA, DESDE QUE CITADA A FONTE.

ASSINATURA:

E-MAIL:claudia @lapetina.com.br

Lapetina, Claudia Maria Lavieri

L311c Uma contribuição para a avaliação da qualidade no dimensionamento dos espaços da habitação / Claudia Maria Lavieri Lapetina. - - São Paulo, 2007.

198 p. : il.

Dissertação (Mestrado - Área de Concentração : Tecnologia da Arquitetura ) - FAUUSP.

Orientador:José Jorge Boueri Filho.

1. Habitação (Dimensionamento) 2. Ergonomia I. Título 


\section{RESUMO}

LAPETINA, Claudia M. Lavieri, Uma Contribuição para a Avaliação da Qualidade no Dimensionamento dos Espaços da Habitação. 2007 198 folhas Dissertação (Mestrado) - Faculdade de Arquitetura e Urbanismo, Universidade de São Paulo, São Paulo, 2007.

A presente pesquisa teve por finalidade a avaliação da qualidade dimensional dos compartimentos que compõem as habitações através da análise do Uso, da Função e das Atividades desenvolvidas nestes ambientes. Inicialmente foram inventariados 216 apartamentos selecionados dentre os lançamentos imobiliários realizados no município de São Paulo, entre os anos de 2000 a 2005, universo estudado pelo "Inventário das Recomendações Dimensionais dos Espaços, Equipamentos e Mobiliário da Habitação" FAPESP 03/09.069-1, BOUERI J.J., (2004) ${ }^{1}$, do qual o autor foi colaborador com o detalhamento de todos os arranjos dos ambientes em trabalho programado "Pesquisa de Composição de Mobiliário e Equipamentos da Habitação" (2004). Posteriormente, foi realizado um aprofundamento nos apartamentos de quatro dormitórios, verificando o uso dos espaços em função das atividades ali exercidas no segundo trabalho programado do autor. Com base nesse aprofundamento, foram aplicados dois tipos de avaliação da Qualidade Habitacional, inicialmente o "Método de Avaliação da Qualidade Arquitetônica Habitacional" de PEDRO, João Branco (2003) nos quesitos relativos ao dimensionamento e posteriormente os "Índices

${ }^{1}$ O texto irá se referir a este trabalho como - Inventário BOUERI FAPESP-. 
Ergonômicos da Habitação", Prof. Dr. BOUERI, J.J. (2001)².Com base nos resultados obtidos na avaliação, a pesquisa buscou concluir com o tipo de qualidade dimensional existente nos apartamentos lançados no mercado imobiliário da cidade de São Paulo. A relevância do estudo criterioso do dimensionamento habitacional extrapola o âmbito do projeto arquitetônico devido à relação de interdependência com os preços dos apartamentos, principalmente nas grandes cidades, como é o caso de São Paulo. Este fator, associado ao custo da terra urbana, forma conjunto que compõe o valor de venda dos apartamentos.

Palavras Chave: habitação, qualidade habitacional, ergonomia, dimensionamento e mercado imobiliário.

${ }^{2}$ BOUERI, J.J. 2001 Apostila da AUT 5809 - Modelos de Dimensionamento dos Ambientes da Habitação - CPG FAU USP. 


\section{ABSTRACT}

LAPETINA, Claudia M. Lavieri. Contribution to the Quality Evaluation of the Habitation Spaces Sizing .198 pgs. Dissertation (Master Degree) Faculdade de Arquitetura e Urbanismo, Universidade de São Paulo, São Paulo, 2007.

The purpose of this research was to evaluate the dimensional quality of habitation compartments. Witch was accomplished by the analysis of Use, Function and Activities performed at these environments. Initially, 216 apartments were selected amongst the real state launchings in the São Paulo city, between the years of 2000 and 2005 were inventoried. Those units also belong to the "Inventory of the Dimensional Recommendations for Spaces, Equipment and Furniture at the Habitation" FAPESP 03/09.069-1, BOUERI J.J., (2004), having the rooms disposal (lay out's) already been studied in detail by the author. Afterwards, a deepening study on the four bedroom apartments was carried trough by the same author, verifying the space uses in function of the activities there developed. Based in this new study, two types of evaluation of dwelling quality were applied: at first "Evaluation Method of Architectural Dwelling Quality" PEDRO, João Branco (2003) in the sections of dimension and afterwards the "Ergonomic Rate of Dwelling", BOUERI (2001).Based of the gotten results the research was directed to the type of dimensional quality of the apartments launched in the real estate market in the city of São Paulo.The importance of the careful study of dimension in the dwellings went beyond the scope of the architectural project due to the interdependent relationship between the market price and the measure of the building, mainly in the great cities, as it is in São Paulo. This factor plus the price of urban soil, compound the market value of the apartments.

Key words: dwelling, dwelling's quality, ergonomics and real state. 
Agradecimentos

Eu agradeço inicialmente ao meu orientador, Prof. Dr. BOUERI , J.J. que me acolheu em seu grupo de pesquisa e com muita paciência me conduziu na execução deste trabalho, unindo a minha experiência profissional a busca pelo conhecimento científico.

Agradeço ao Prof. Dr. Silvio Sawaya por me devolver a poesia da profissão que estava adormecida dentro de mim.

Ao Arquiteto Dr. João Branco Pedro, pela atenção e apoio no processo de definição do objeto de estudo e pela orientação.

Agradeço muito ao grupo de pesquisa que não deixou de me estimular nos momentos difíceis:

Alexandre Kenchian

André Luiz Souza Barbosa

João Alberto Canteiro

Marcelo Mendonça

Maria Valéria Affonso Lopes

Agradeço a Prof. Sonia Kinjo Sampaio pela ajuda e revisão desta pesquisa. 
Dedicatória

Dedico este trabalho a minha família,

aos meus pais

Claudia Luiz Lavieri e

Amélia Wilma Caporal Lavieri (i.m.)

...mãe tenho certeza que ficaria muito feliz em poder acompanhar mais esta etapa da minha vida em busca

pelo conhecimento.

ao meu marido Danilo Jose Quito e meus filhos

Daniela Lavieri Lapetina, Bruno Lavieri Lapetina que partilham comigo a experiência de viver em família. 
De onde nasce e como se organiza no espírito humano esta necessidade ou esta vontade de "espacejar" é uma questão outra e bem mais complexa. Mas seja qual for o impulso inicial, não há dúvida de que mediante esse processo o homem reconhece e define uma relação entre si mesmo e o mundo, delimita uma "zona de experiência" dentro da qual a própria personalidade é, de todo modo "ativa". Na dimensão ou na forma (...) o homem desenha o limite do seu próprio agir, o prazo de validade da sua própria experiência.

Giulino Carlo Argan ,2001, pag. 82 Projeto e Destino, 


\section{Sumário}

Introdução

\section{Estrutura da Dissertação}

\section{Capítulo I}

A Evolução das Plantas das Habitações

PARTE I - A Dimensão nas Habitações uma Visão Global.

1. A Casa Pré Urbana.

1.1.Habitações Temporárias Transitórias.

1.2. Habitações Temporárias Regulares e Irregulares.

1.2.1. Inuit Igloo- Iglu dos Esquimós.

1.2.2. Maloca dos Cubeo e Erigbaagtsa - Amazonia.

1.3. Habitações Semi-Permanentes.

1.3.1. Mesakin Quisar Cluster.

1.3.1. Pueblos.

1.4. Habitações Permanentes.

1.4.1. Cavernas Chinesas.

2. A Casa das Civilizações da Antiguidade.

2.1. Mesopotâmia - Sumérios.

2.1.1.Casa 2 período de Lars na cidade de UR.

2.2. Egito.

2.2.1. Casa "Del El Medina".

2.2.2. Casa Dupla "Khaun".

2.3. Monjejo Daro India 3250 a 2750 a .C.

\subsubsection{Casa 54}

2.3.2. Casa 8.

2.4. A Casa Urbana da Babilônia e Assíria - 687 A 637 a .C.

2.4.1. Red House

2.5. As Casas Gregas e Romanas

2.5.1.Grécia - Helênica e Helenística

2.5.1.1. A Casa de Muitas Cores

2.6. Roma

2.7. A Tradicional Casa Islâmica

2.8. A Tradicional Casa Hindu

2.9. A Tradicional Casa Urbana Chinesa

2.10. A Tradicional Casa Urbana Japonesa 
3. Casas Ocidentais da Era Moderna

3.1.Idade Média

3.1.1. Alta Idade Média- Habitações Típicas

3.1.1.1.Habitações Tipo Torre

3.1.2. Baixa Idade Média

3.1.3.Final Da Idade Média

3.2. Renascimento

3.2.1. As Praças Residenciais

3.2.1.1. Casa na Queen's Square. (1727)

3.3. A Casa de Cidade

3.3.1. Cadogan Square $n^{\circ} 68$ arquiteto Norman Shaw

3.4. Séc XIX - Industrialismo

3.4.1. Tenement Buildings - "Modelo de Casa para Famílias" - 1780

3.4.2. "Bylaws Model's "-Nottingham-1879

3.4.3. As Vilas Suburbanas

3.4.4. Apartamentos em Paris

3.4.5. Apartamentos em Londres 1853

3.5. Residências entre duas Guerras Mundiais

3.5.1.Cidades Jardim

3.5.1.1. Hampstead

3.5.1.2. Letchworth

3.5.2. Estados Unidos

3.5.3. Índia - O Bangalô

3.5.4.França

3.5.5. Alemanha

3.5.6. América Latina

3.6. Século XX - De 1950 A 2000

3.6.1. Casa Suburbana Americana

3.6.2. Casa Pátio ou Casa Jardim

3.6.3.Casa Urbana Geminada

3.6.4. Edifício Alto de Apartamentos

3.6.5. Edifício De Apartamentos Populares

3.6.6. Edifício Residencial Isolado

3.6.7. Edifício Misto

3.6.8. Habitação Coletiva - Condomínios

3.6.9. Edifício Convertido em Residência - loft's

3.6.10. NOVO URBANISMO 
PARTE II A Dimensão nas Habitações Paulistas.

1.Tempos de Colônia

1.1.Conjunto de Características que influenciaram na tipologia e na construção das primeiras casas.

1.2. Casas de Cidade.

1.3. Casas Rurais.

2.O Brasil do Século XIX, o Brasil Independente.

3. O Ecletismo e a Revolução Industrial.

3.1. A lluminação Artificial.

3.1.1 Industrialização de Alimentos como Modificadora de Dimensões.

4.Os Palacetes Paulistanos (1867 a 1918)

5. A Modernidade em são Paulo

5.1. A Queda do Café

6. A verticalização

6.1. Edifício Esther 1935

6.2. Edifício Sra. Germanie Buchard

6.3. Edifício Louveira 1946

6.4.Edifício Prudência 1944- 1948

6.5.Apartamento Wiliam Malluf - 1962

\section{Capítulo II}

\section{Qualidade Habitacional}

1. Embasamento Teórico.

2. Autores Qualidade Habitacional referenciados por PEDRO, J. B.. Método de Análise de Projetos, proposto por Alexandre Klein.

Método de Racionalização de soluções da Habitação proposto por Nuno Portas e A .Costa. Método QUALITEL.

Método SEL.

Método Dluhousen.

3. O Método de PEDRO, João Branco.

3.1. O Programa de Qualidade Residencial

3.1.1. A Definição do Programa 

a. Identificação e Classificação dos Usuários
b. Classificação dos Espaços Habitacionais
c. Classificação de Funções de Uso
d. Tipologias

3.1.2. Exigências de Qualidade

a .Formulação da Qualidade

b. Definição dos Níveis de Qualidade

c . Condições do Meio de uma Área Residencial

d . Fontes para a Definição de Exigências de Qualidade

3.1.3. Modelos de Composição dos Ambientes

3.2. O Método de Avaliação da Qualidade Residencial

3.2.1. Processo de Apoio a Decisão
a . Fase de Formulação
b . Fase de Avaliação

3.2.2. Método de Avaliação por Multicritério
a . Arvore de Pontos de Vista
b. Pontos de Vista Elementares
c. Descritores
d. Critérios de Avaliação
e. Critérios de Ponderação

3. 2.3. Método para Obtenção de Síntese
a . Método aditivo simples
b. Forma de apresentação dos resultados
c. Análise dos resultados

4. Qualidade do Dimensionamento nos Ambientes da Habitação segundo Prof. Dr. BOUERI,J.J.

4.1. Antropometria para a Arquitetura Habitacional, Dissertação de Mestrado FAU USP, 1985.

4.2. Antropometria Fator de Dimensionamento da Habitação.

4.3.Índices de Avaliação Ergonômica do Dimensionamento da Habitação.

\subsection{Espaços de Atividades}

5. Síntese do Capítulo

\section{Capítulo III}

Aplicação de Métodos de Qualidade Residencial em Empreendimentos do Mercado Imobiliário

1. Etapas para a Aplicação do Método de Qualidade Residencial de PEDRO, J.B.

1.1.Definição do Problema 
1.2. Identificação dos atores

1.3. Aferição dos Objetivos

1.4. Identificação das soluções

1.5. Aferição dos critérios de Avaliação

1.6. Verificação dos Critérios de Ponderação

1.7. Avaliação dos Pontos de Vista Elementares

1.8. Aplicação do Método de Síntese dos Resultados

1.9. Análise dos Resultados

2. A Árvore dos Pontos de Vista a ser Utilizada

2.1. Exigências de Uso

2.1.1. Capacidade

2.1.1.1. Definição dos Programas de Ambientes

2.1.1.1.1.Elementos de Avaliação Programa de Ambientes

2.1.1.1.2. Critérios de Avaliação dos Programas de Ambientes

2.1.1.1.3.Resultados Obtidos na Avaliação dos Programas de Ambientes

2.1.1.1.4.Análise dos Resultados dos Programas de Ambientes

2.1.1.2. Definição dos Programas de Mobiliário e Equipamentos Mínimos por Tipologia

2.1.1.2.1.Elementos de Avaliação dos Programas de Mobiliário e Equipamentos

2.1.1.2.2. Critérios de Avaliação dos Programas de Mobiliário e Equipamentos

2.1.1.2.3.Resultados Obtidos na Avaliação dos Programas de Mobiliário e Equipamentos

2.1.1.2.4. Análise dos resultados obtidos

2.1.2 Espaciosidade

2.1.2.1.Dimensão Útil

2.1.2.1.1.Elementos de Avaliação para Dimensão Útil Varandas

2.1.2.1.2. Critérios de Avaliação para Dimensão Útil Varandas

2.1.2.1.3.Resultados Obtidos na Avaliação da Dimensão Útil

2.1.2.2. Área útil

2.1.2.2.1.Elementos de Avaliação para Área Útil

2.1.2.2.2. Critérios de Avaliação Área Útil

2.1.2.2.3. Resultados Obtidos na Avaliação da Área Útil

2.1.2.3. Resultados Obtidos para Espaciosidade

2.1.2.4. Análise dos Resultados Obtidos na Avaliação da Espaciosidade

2.1.3. Funcionalidade

2.1.3.1. Elementos de Avaliação da Funcionalidade

2.1.3.2. Critério de Avaliação para Funcionalidade

2.1.3.2. Resultados Obtidos para Funcionalidade

2.1.3.4. Análise dos resultados Obtidos na Avaliação da Funcionalidade 
3. Aplicação do Método de Síntese dos Resultados

3.1.Tabelas dos Valores de Desempenho

3.2. Gráfico Comparativo Global

3.3. Análise dos resultados

3.3.1.A variação do valor de desempenho global em função da área privativa, dentro da adequação espaço funcional.

3.3.2. Variação do valor de desempenho global em função dos demais pontos de vista.

4.Qualidade dos Ambientes da Habitação segundo Prof. Dr. BOUERI (2001) Avaliação dos Índices Ergonômicos

5.Síntese do Capitulo

IV. Considerações Finais

Referências Bibliográficas

Glossário

Anexos 


\section{Lista de Figuras e Imagens}

As figuras e imagens estão numeradas por capítulos, Exemplo Fig. I 03.... 05 é a figura 3 do Capítulo I que está na página 05.

\section{Introdução}

Fig. 01 llustração Espaço de atividade

\section{Capitulo I}

Fig. I 01 Exemplo de Habitação Temporária AFRICAN BUSHMEN SKERM 04

Fig. I 02 Habitação Temporária BAMBUTI PYGMY HUT 04

Fig. I 03 Habitação Temporária BAMBUTI PYGMY HUT 04

Fig. I 04 Elevação,Corte Longitudinal e Planta INUIT IGLOO 05

Fig. I 05 Imagens INUIT IGLOO 06

Fig. I 06 Elevação e Planta -CUBEO MALOCA 06

Fig. I 07 Planta MESAKIN QUISAR CLUSTER 08

Fig. I 08 Imagem Ilustrativa MESAKIN QUISAR CLUSTER 08

Fig. I 09 Implantação e Vista PUEBLOS 08

Fig. I 10 Caverna Chinesa Vista $\quad 10$

Fig. I 11 Cavernas Chinesas Planta 10

Fig. I 12 Mapa de localização dos exemplos $\quad 12$

Fig. I 13 Casa 3 LARSA 13

Fig. I 14 Casa DEIR EL MEDINA 1540-101aC $\quad 14$

Fig. I 15 Casa Dos Trabalhadores KAHUN 15

Fig. I 16 Casa Dos Trabalhadores KAHUN detalhe $\quad 15$

Fig. I 17 Imagem Ilustrativa- Saída de dejetos MONJERO DARO. 17

Fig. I 18 Casa 54 MONJERO DARO 17

Fig. I 19 Planta Casa 8 MOHENJO- DARO 18

Fig. I 20 Planta Red House Assur $\quad 19$

Fig. I 21 Cidade de Atenas $\quad 20$

Fig. I 22 Casa de Muitas Cores Olynthos Grécia 22

Fig. I 23 Imagem Tetos decorados Pompéia 23

Fig. I 24 Imagem Piso em mosaico Pompéia 23

Fig. I 25 Casa 6 e 7 Pompéia 24

Fig. I 26 Planta Casa Dar Sfar 26

Fig. I 27 JAISALMER $\quad 27$

Fig. I 28 Imagem Exemplo de janelas de Jaisalmer 27

Fig. I 29 Planta SIHEYUAN 28

Fig. I 30 e I31 Fotos Ilustrativas Casa Chinesa 29

Fig. I 32 Planta e Corte CASA MACHIYA, Kyoto 30

Fig. I 33 Schwäbisch Hall (Germânia) TURMANHAUS 34

Fig. I 34 Imagem Ilustrativa da Muralha de Drubrovinik 35 
Fig. I 35 Elevação e plantas da Casa típica da Placa 36

Fig. I 36 Fachada Place de Vosges (Place Royale) 40

Fig. I 37 Desenho ilustrativo da Place Royale 40

Fig. I 38 Foto llustrativa da Place Royale $\quad 41$

Fig. I 39 Planta Convent Garden $\quad 42$

Fig. I 40 Imagem Ilustrativa Convent Garden 42

Fig. I 41 Pav. Superior Casa Dupla - QUEEN'S SQUARE BATH 43

Fig. I 42 Pav. TérreoCasa Dupla na QUEEN'S SQUARE BATH 43

Fig. I 43 Imagem Ilustrativa de QUEN'S SQUARE EAST SIDE 43

Fig. I 44 Imagem Ilustrativa KING'S CIRCUS 44

Fig. I 45 CADOGAN SQUARE Londres $\quad 46$

Fig. I 46 Imagem llustrativa- CADOGAN SQUARE 48

Fig. I 47 Exemplo de Casa em Cidade em Nova York 49

Fig. I 48 WEAVER'S TENEMENTS 51

Fig. I 49 BIRMAMINGHAN COURTS 51

Fig. I 50 Bylaw Housing, Nottingham 52

Fig. I 51 Exemplo de Vila Suburbana - Inglaterra 53

Fig. I 52 Apartamento a rua Theodore de Banville 55

Fig. I 53 Apartamento a Victoria Street 56

Fig. I 54 Imagens Ilustrativas Welwyn Garden City 58

Fig. I 55 Cidade Jardim Hampstead 58

Fig. I 56 Cidade Jardim LENTCHWORTH 59

Fig. I 57 LENTCHWORTH Vista Interna e Planta 60

Fig. I 58 Imagem Ilustrativa Oak Park Home II 61

Fig. I 59 Oak Park Home Elevação Frontal 61

Fig. I 60 Planta Pav. Térreo Oak Park Home 62

Fig. I 61 Corte Bangalô Indiano $\quad 62$

Fig. I 62 Planta Bangalô Indiano 63

Fig. I 63 Maison Citroen 64

Fig. I 64 Casa Pátio Mies Van der Rohe 66

Fig. I 65 Planta Casa Pátio Jorn Utzon 67

Fig. 166 Plantas Casa Geminada I.M. Pei 68

Fig. I 67 Silver Towers -I.M. Pei And Associates Nova York 69

Fig. I 68 Plantas e Corte Price Tower, Bartlesville Oklahoma Frank Lloyd Wrigh 71

Fig. I 69 Planta Loft Alan Burchsboum Nova York $\quad 72$

Fig. I 70 Planta Casas Urbanas Paulistas, séc XVII e XVIII 77

Fig. I 71 Planta Fazenda do Tatu São Carlos -1850 78

Fig. I 72 Planta de distribuição linear da Casa Paulista Urbana 82

Fig. I 73 Planta Sítio do Calú - Embu Casa Paulista Rural 83

Fig. I 74 Planta Térreo- Palacete Barão de Piracicaba II 84 
Fig. I 75 Planta $1^{\circ}$ Pavimento- Palacete Barão de Piracicaba II 84

Fig. I 76 Detalhe Planta Sala de Jantar Palacete Barão de Piracicaba II 87

Fig. I 77 Planta 9 Pavimento Edifício Esther 90

Fig. I 78 Edifício Sra. Germanie Buchard Cobertura 91

Fig. I 79 Edifício Sra. Germanie Buchard Pavimento Tipo 92

Fig. I 80 Foto Edifício Louveira $\quad 92$

Fig. I 81 Planta apartamento tipo Edifício Louveira 93

Fig. I 82 Edifício Louveira Implantação e Compartimentos 93

Fig. I 83 Edifício Prudência Planta original $\quad 94$

Fig. I 84 Foto Edifício Prudência $\quad 94$

Fig. I 85 Apartamento William Malluf 95

\section{Capítulo II}

Fig. II 01 e 02- Ilustração das proporções do Corpo Humano -Dessen

www.ac-versailles.fr/pedagogi/artsplastiques/...17/01/2007.

Fig. II 03 -Modulor 1

http://www.architektur.tudarmstadt.de/powerhouse/db/248,id 15,s Papers.sp.fb15 17/01/2007.

Figura II 04 Desenhos e Fotos - Trabalho Programado do autor.

\section{Capítulo III}

Fig. III 01 Empreendimento 4 Nova Mooca T2

III 19

Fig. III 02 Empreendimento 5 Eco Vitta T2 finais 1, 2, 4 e $5 \quad$ III 19

Fig. III 03 Empreendimento 3 - T2 Eco Vitta -finais 3 e $6 \quad$ III 21

Fig. III 04 Empreendimento 166 T4 Arandu III 22

Fig. III 05 Empreendimento 5 - T3 City Park III 28

Fig. III 06 Empreendimento 2 - T3 Área privativa III 28

Fig. III 07 Empreendimento 1-T2 Desenho publicitário III 31

Fig. III 08 Empreendimento 1-T2 Desenho com os raios inscritos III 31

Fig. III 09 Empreendimento 1-T2 Desenho - ÀREA ÚTIL III 34

Fig. III 10 Desenho Funcionalidade Empreendimento 1- T2 -e Detalhe III 41

Fig. III 11 Desenho Funcionalidade Cozinha Empreendimento 2-T3 III 44

Fig. III 12 Cama de Casal Aplicações Dimensionais III 54

Fig. III 13 Arranjo de banheiro mais encontrado III 54

Fig. III 14 Bacia Aplicações Dimensionais III 54 


\section{Lista de Tabelas:}

\section{Capitulo I}

Tabelas

páginas

Tabela 01 MESAKIN QUISAR CLUSTER $\quad 07$

Tabela 02 CHINESE CAVE $\quad 10$

Tabela 03 Casa DEIR AL MEDINA 14

Tabela 4 Casa Dos Trabalhadores KAHUN 15

Tabela 5 Casa 54 MOHENJO DARO 16

Tabela 6 Casa 8 MOHENJO DARO 18

Tabela 7 - RED HOUSE Assur 19

Tabela 8 Casa de Muitas Cores 22

Tabela 9 Casa de DAR SFAR 25

Tabela 10 Casa de BEIJING 28

Tabela 11 TURMHAUS 33

Tabela 12 Típica CASA NA RUA PLACA 36

Tabela 13 CASA DUPLA Quen's Square $\quad 42$

Tabela 14 CADOGAN SQUARE No 68

Tabela 15 BIRMINGHAM: COURTS 52

Tabela 16 BYLAW HOUSING 52

Tabela 17 Vila Suburbana Londres $\quad 54$

Tabela 18 Apartamento a rua Theodore de Banville 56

Tabela 19 Cidade Jardim LENTCHWORTH 60

Tabela 20 Oak Park Home Frank Lloyd Wright 61

Tabela 21 Bangalô Indiano 63

Tabela 22 Casa Pátio Jorn Utzon $\quad 67$

Tabela 23 Casa Geminada I.M. PEI 68

Tabela 24 Prédio de Apartamentos Silver Tower $\quad 69$

Tabela 25 Casas Urbanas Paulistas $\quad 77$

Tabela 26 Fazenda do Tatu $\quad 79$

Tabela 27 Palacete Barão de Piracicaba II- Pav. Térreo 85 


\section{Capítulo II}

Quadro 1 Arvore de Classificação de Exig. de Qualidade Habitacional 11

Tabela 01 Área Útil da Habitação 25

Tabela 02 Área Útil do Ambiente 25

Tabela 03 Composição de Mobiliário e Equipamento 25

\section{Capítulo III}

Tabela 01 Programa de Ambientes T2 08

Tabela 02 Programa de Ambientes T3 09

Tabela 03 Programa de Ambientes T4 09

Tabela 04 Ponderação Programas de Ambientes 15

Tabela 05 Valor Desempenho Programa de Ambientes 15

Tabela 06 Resumo da Avaliação Programa de Ambientes T2 16

Tabela 07 Resumo da Avaliação Programa de ambientes T3 16

Tabela 08 Resumo da Avaliação Programas de Ambientes T4 17

Tabela 09 Programa de Mobiliário e Equipamentos para T2 20

Tabela 10 Programa de Mobiliário e Equipamentos para T3 21

Tabela 11 Programa de Mobiliário e Equipamentos para T4. 22

Tabela 12 Valor de Desempenho Prog. de Mob. e Equip. 25

Tabela 13 Resumo da Avaliação Mobiliário e Equipamentos T2 25

Tabela 14 Resumo da Avaliação Mobiliário e Equipamentos T3 25

Tabela 15 Resumo da Avaliação Mobiliário e Equipamentos T4 26

Tabela 16 Dimensão Útil T2 32

Tabela 17 Valor de Desempenho- Dimensão Útil 32

Tabela 18 Área útil Empreendimento 1 Home Flex Itaim T2 32

Tabela 19 Valor de Desempenho Área Útil 35

Tabela 20 Resumo da Avaliação Espaciosidade para T2 e T3 35

Tabela 21 Resumo da Avaliação da Espaciosidade para T4 36

Tabela 22 Ponderação Funcionalidade 41

Tabela 23 Valores de Desempenho Funcionalidade 41

Tabela 24 Funcionalidade apartamentos T2 41

Tabela 25 Funcionalidade T3 42

$\begin{array}{lll}\text { Tabela } 26 & \text { Funcionalidade T4 } 42 \text { e } 43\end{array}$

Tabela 27 Trecho da tabela de Valor Global de Desempenho Global 47

Tabela 28 Resumo Índices Ergonômicos T2 51

Tabela 29 Resumo Índices Ergonômicos T3 52

Tabela 30 Resumo Índices Ergonômicos T4 52 


\section{Lista de Gráficos}

\section{Capítulo III}

Gráfico 1 Critério adotado para a Avaliação de Programas 15

Gráfico 2 Variação dos Val. de Des. dos Prog.de Amb. por Tipologia 18

Gráfico 3 Variação dos Val. de Des. dos Prog. de Amb. por Área Privativa 18

Gráfico 4 Índice de módulos de Armários de roupas/ pessoa 23

Gráfico 5 Critério adotado para Avaliação Mobiliário e Equipamentos 25

Gráfico 6 Variação dos Val. De Dês. Dos Prog.de Mob. e Equip. x Área Privativa 27

Gráfico 7 Critério de Avaliação da Dimensão Útil das Varandas 30

Gráfico 8 Variação do Val. de Dês da Dim. Útil x Área Privativa 33

Gráfico 9 Critério de Avaliação da Área Útil da Varanda 34

Gráfico 10 Variaçao do Valor de Dês. Da Área útil x Área Privativa 37

Gráfico 11 Variação do Val. de Dês. da Func. x da Área Privativa 43

Gráfico 12 Comparativo Global Dos Valores de Desempenho 48 


\section{Abreviaturas}

ASBEA Associação Brasileira dos Escritórios de Arquitetura

LNEC Laboratório Nacional de Engenharia Civil

CEF Caixa Econômica Federal

FAU Faculdade de Arquitetura e Urbanismo

USP Universidade de São Paulo

FUPAM Fundação para Pesquisa Ambiental

Fig. $\quad$ Figura

FAPESP Fundação de Amparo a Pesquisa do estado de São Paulo.

Pág. Página.

IMAE Instituto Metropolitano de Altos Estudos das Faculdades Metropolitanas Unidas.

EUA Estados Unidos da América 


\section{Glossário}

Alpendre:

alpendre não é varanda, segundo LEMOS, alpendre é uma cobertura situada fora do perímetro das paredes mestras de uma construção

\section{Área de uso comum}

É a área que pode ser utilizada em comum por todos os proprietários do prédio ou condomínio, sendo livre o acesso e o uso, de forma comunitária, Por exemplo: portaria do prédio, áreas de lazer, corredores de circulação, escadas.Definidas pela LEI 4.591 DE 16/12/64 - Art. 32 E NBR-12.721

Área Privativa

É a área do imóvel da qual o proprietário tem total domínio. É composta pela superfície limitada da linha que contorna externamente as paredes das dependências (cobertas ou descobertas) de uso privativo e exclusivo de proprietário. Definidas pela

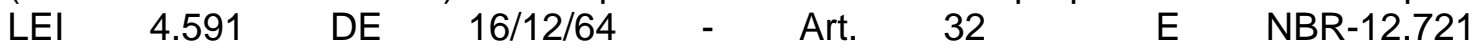
Fonte:http://www.lopes.com.br/site/glossarioimobiliario/glossario.asp

\section{Área Útil}

É a área individual. É a soma das áreas dos pisos do imóvel, sem contar as paredes, ou seja, restrita aos limites. Também é conhecida como área de vassoura. É a área mais importante no momento da compra do imóvel, devendo ser item a ser questionado durante a transação do negócio. Definidas pela LEI 4.591 DE 16/12/64 - Art. 32 E NBR-12.721.

\section{Fonte:http://www.lopes.com.br/site/glossarioimobiliario/glossario.asp}

\section{Área Computável}

É a área determinada pelos Planos Diretores e pelas leis de uso e ocupação do que se pode construir em determinada zona da cidade, e vende-se como privativa com algumas exceções como é o caso das varandas e varandas de serviço, limitadas até $10 \%$ da área de projeção (ocupação horizontal no lote).

A área construída computável também pode ser definida como a soma das áreas cobertas de todos os pavimentos de uma edificação, que são consideradas para o para o cálculo do coeficiente de aproveitamento, segundo Cláudio Bernardes em Plano Diretor Estratégico, e a atividade Imobiliária em São Paulo, página 27, para a editora Tula Melo - 2005.

A área computável é definida também como - parcela da área edificada considerada para efeito do calculo do coeficiente de aproveitamento pela 
LPUOS -Lei de Uso e Ocupação do Solo. Pág. 129 anexo 1 do Código de Obras e Edificações do Município de São Paulo por Block, Luiz Laurente.

\section{Top Imobiliário}

O "Top Imobiliário" é promovido pelo jornal O Estado de S. Paulo, em parceria com a Empresa Brasileira de Estudos de Patrimônio (Embraesp). A cada edição são homenageadas as empresas da Região Metropolitana de São Paulo que melhor se classificam no ranking preparado todos os anos pela Embraesp. 


\section{Introdução}

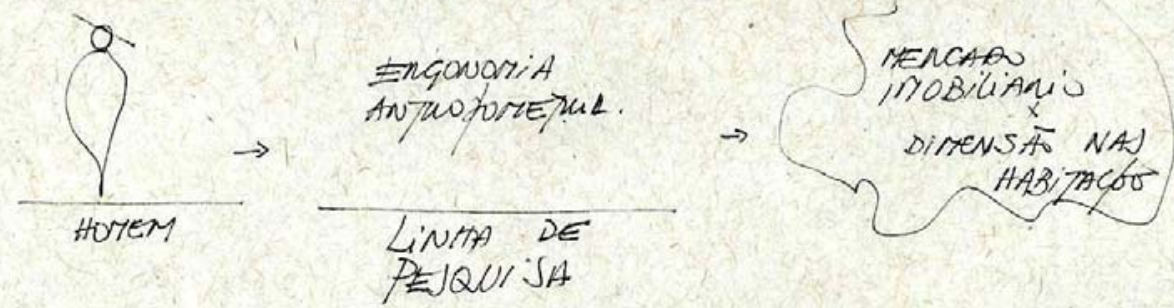




\title{
INTRODUÇÃO
}

\author{
Palavras-chave: Qualidade Habitacional, Ergonomia,
} Dimensionamento e Mercado Imobiliário.

"Desde as civilizações antigas, era a casa que demarcava a cidadania e a posição do indivíduo. Ao mesmo tempo, a moradia é o seu ponto de fixação, sua referência de estabilidade". ${ }^{1}$

O estudo da habitação sempre foi referencia de muitos trabalhos de pesquisa em vários campos da ciência, devido a sua importância dentro do ambiente construído e sua relação de interdependência com o homem, extrapolando os aspectos do espaço construído.

A relevância do estudo criterioso da dimensão dentro das habitações é um tema atual, e pode ser considerada uma necessidade. Principalmente nas grandes cidades, como é o caso de São Paulo, aonde o custo do metro quadrado da área construída e o custo da "terra urbana", associados às leis de uso e ocupação do solo, formam conjunto importante e limitador nas decisões projectuais.

O mercado imobiliário, utiliza como critério de avaliação de apartamentos a localização (valor da terra urbana) associada a área privativa expressa em $\mathrm{m}^{2}$, consequentemente a busca pelo maior e melhor

\footnotetext{
${ }^{1}$ CRITELLI, Dulce Mára, professora de filosofia da PUC SP, citação em artigo para o site da livraria Cultura - no 110, em agosto de 2003.
} 
aproveitamento do lote está invariavelmente relacionada às áreas e as dimensões dos compartimentos que compõe a unidade habitacional ${ }^{2}$.

A motivação deste trabalho teve início na pesquisa "Inventário das Recomendações Dimensionais dos Espaços, Equipamentos e Mobiliário das Habitações"3, por grupo de pesquisadores do qual o aluno faz parte, coordenados pelo prof. Dr. José Jorge Boueri, que estuda a qualidade dimensional, dentro da disciplina AUT 5807 -"Modelos de Dimensionamento dos Espaços da Habitação" na CPG FAU USP . Este trabalho inventariou os móveis, equipamentos e arranjos de apartamentos de 1 a 4 dormitórios lançados nos últimos 3 anos e publicados na revista "QUAL", na cidade de São Paulo, visando o desenvolver uma análise das dimensões propostas através do mobiliário e equipamentos sugeridos..

Os empreendimentos do mercado imobiliário foram utilizados na pesquisa, pois espelham os anseios das famílias, ou seja, até o mais simples destes desenhos publicitários de projetos de arquitetura, indica os equipamentos e mobiliário, constantes ou vislumbrados pelas pessoas no cotidiano da vida familiar.

No decorrer do trabalho de pesquisa, observamos diversas leituras que poderiam ser realizadas, de acordo com a variação de arranjos, dimensionamento, flexibilidade das plantas propostas e número de ambientes

\footnotetext{
${ }^{2}$ Vide anexo 10.

3 FAPESP 03/09.069-1, 2004 BOUERI J.J., Inventário das Recomendações Dimensionais dos Espaços, Equipamentos e Mobiliário, de agora em diante o texto irá utilizar apenas InventárioFAPESP, quando fizer referencia a esta pesquisa.

${ }^{4}$ Revista Qual, editora Abril - catálogo de vendas de imóveis.
} 
que sofrem variações relevantes de dimensões de acordo com a área privativa ${ }^{5}$ do imóvel.

Conceitualmente, os edifícios habitacionais são construídos para pessoas, para que se apoderem e ocupem os espaços ali gerados. Logo, as dimensões e os movimentos do corpo humano são determinantes da forma e do tamanho dos espaços, assim como na localização do mobiliário e dos equipamentos contidos nos apartamentos. Assim, a aplicação da antropometria e da ergonomia pode ser utilizada como um fator decisório no processo projectual do arquiteto para a definição das dimensões dos espaços edificados.

A pesquisa conclui com a aplicação do método de avaliação da qualidade habitacional no quesito "exigências de uso" de PEDRO,João Branco, pesquisador do Laboratório Nacional de Engenharia Civil em Portugal e uma avaliação dos mesmos apartamentos através dos índices ergonômicos do Prof. Dr. BOUERI, J.J..Esta aplicação foi realizada inicialmente em plantas de apartamentos de 4 dormitórios pertencentes ao conjunto de plantas do Inventário BOUERI FAPESP, após a conclusão destas, os orientadores sentiram necessidade de uma referencia em relação aos apartmantos de 3 e 2 dormitórios , para complementar a avaliação.

A dissertação foi estruturada conforme segue:

- A escolha do tema e do objeto de pesquisa,

- A justificativa da pesquisa e sua relevância acadêmica,

- Os objetivos da pesquisa a serem alcançados,

- Contribuições acadêmicas e práticas da pesquisa.

\footnotetext{
${ }^{5}$ área privativa - É a área do imóvel da qual o proprietário tem total domínio. É composta pela superfície limitada da linha que contorna externamente as paredes das dependências de uso
} 


\section{Objeto de Pesquisa}

O objeto de pesquisa deste trabalho foi a avaliação da qualidade do dimensionamento de apartamentos de 4 dormitórios pertencentes ao mercado imobiliário da cidade de São Paulo, com o recorte de faixa de área, entre $90,00 m^{2}$ a 140,00m² de 2001 a 2005. Após a conclusão desta avaliação sentiuse necessidade de uma comparação com apartamentos de 2 e 3 dormitórios, tendo sido abrangido também estas duas tipologias ao objeto de pesquisa.

\section{Justificativa da Pesquisa}

Considerando-se a importância do estudo da área construída habitacional na cidade de São Paulo, está sendo adotada uma citação do prof. Bruno Rudolfer ${ }^{6}$, para melhor compreensão do assunto abordado, ele considera :

"a questão da habitação primordialmente de ordem social e o habitar é um ajustamento cultural...

... a habitação constitui problema quando o desejado e o existente não coincidem....

A habitação desejada não pode ser mero produto da cogitação daqueles que a planejam, mas tem servir às peculiaridades sociais daqueles que vão nela residir ."

privativo e exclusivo do proprietário.

${ }^{6}$ Professor da Escola de Sociologia e Política, (2002, apud SAMPAIO, Maria Ruth Amaral de, pág. 15 , Promoção Privada da Habitação Econômica e a Arquitetura Moderna 1930-1940). 
Assim podem-se considerar dois tipos de valores pára ilustrar a citação acima:

- Valor simbólico como aquele dado à habitação desejada,- Ou o utilizado por Loureiro e Amorim - em "A Casa Ideal" - aonde o valor simbólico pertence aos não quantificáveis da habitação. È procedente, também, fazer uma analogia utilizando os atalhos dos arquétipos Jungianos, pois em um "mundo cada vez mais preocupado em comprar idéias e emoções embutidas nos produtos"8, a moradia é tratada como produto pelo mercado imobiliário criando um arquétipo, aonde a opção na hora da escolha depende menos da qualidade e mais do significado que ela carrega. Exemplificando, no quesito status, morar em um apartamento de 4 dormitórios tem um significado que vai além da compartimentação e da área útil da moradia.

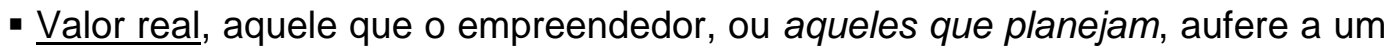
imóvel após a conclusão de todos os gastos para o lançamento a mercado de um empreendimento imobiliário, incluindo os próprios lucros. A saber, custo do lote urbano, custo de construção, investimentos em projetos, emolumentos ${ }^{9} \mathrm{e}$ gastos eventuais.

"Mudanças nesta estrutura de valores, acarretam mudanças no projeto, assim como no uso dos espaços e nos símbolo". ${ }^{10}$

Tendo-se em mente as considerações acima, a área construída é objeto de grande importância para os empreendedores e para os arquitetos

${ }^{7}$ LOUREIRO, Claudia e AMORIM, Luiz - professores da Universidade Federal de Pernambuco em artigo para o site Vitruvius .com.br - texto especial 281- A casa Ideal - fevereiro de 2005.

${ }^{8}$ Citação de Marinho, Luiz Alberto, sobre a publicação de MARK, Margareth e PEARSON, Carol The Hero And The Outlaw, site www.bluebus.com.br 31/03/2006.

${ }^{9}$ São considerados emolumentos as taxas pagas aos órgãos públicos.

${ }^{10}$ Passim 6. 
principalmente, quando buscam compatibilizar "O grau de satisfação das necessidades funcionais ou de conforto" ${ }^{11}$ com a realização de lucro que move o mercado imobiliário, respeitando ainda as limitações impostas pela legislação vigente, através do maior aproveitamento do lote urbano, expresso em número de unidades habitacionais e suas respectivas áreas privativas ${ }^{12}$.

As áreas privativas apresentam-se como conseqüência direta das áreas dos compartimentos que formam a unidade habitacional ou apartamento que é o objeto de estudo desta pesquisa. Assim sendo, a dimensão de uma cama e sua localização dentro do compartimento com o espaço envoltório - espaço de atividades $^{13}$ - são considerados elementos relevantes, pois poderão definir a área do compartimento que abrigará a cama.

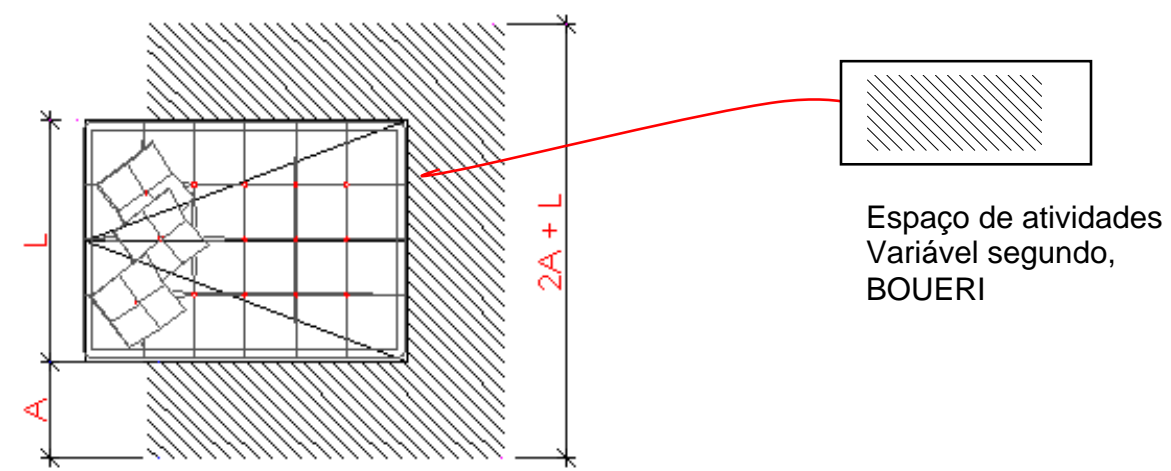

Fig. 1- Espaço de Atividades Fonte:ilustração autor

\footnotetext{
${ }^{11}$ PORTAS, Nuno-Definição e Evolução das Normas da Habitação,1966.

12 Passim 6.

${ }^{13}$ Boueri, J.J. 2004 "A Contribuição da Ergonomia na Formação do Arquiteto"- tese de Livre Docência CPG FAU USP.
} 
As habitações de classes mais abastadas são identificadas pela não superposição de atividades ${ }^{14}$ em um mesmo espaço, portanto os apartamentos de maior área, permitiram uma análise pormenorizada de cada uma atividades em ambientes do espaço habitacional.

\section{Objetivos da Pesquisa}

Os objetivos da pesquisa foram:

- Pesquisar e situar a qualidade dimensional nos apartamentos lançados no mercado imobiliário da cidade de São Paulo, inicialmente de 4 dormitórios dentro da faixa de área $90,00 \mathrm{~m}^{2}$ a $140,00 \mathrm{~m}^{2}$ (a faixa foi escolhida por PEDRO, J.B.,) e posteriormente incluindo também apartamentos de 3 e 2 dormitórios.

- Identificar através dos equipamentos e mobiliário indicados nas peças publicitárias, a existência ou indicação de novas atividades, dentro do espaço habitacional, provocadas pelo modo de vida da sociedade contemporânea, que venham a enriquecer o estudo dimensional habitacional.

- Saber como está sendo feita a apropriação do espaço através da utilização e disposição dos equipamentos, e mobiliário, agregando ou não qualidade no espaço habitacional.

- Saber até que ponto, o projeto prevê as variações de atividades em um mesmo ambiente (superposição de atividades).

- Verificar se a flexibilização de plantas quando prevista funciona como desindexadora do dimensionamento. 


\section{Contribuições Acadêmicas e Práticas da Pesquisa}

"A sociedade urbana contemporânea reflete hoje a complexidade de nossa era, sendo multifacetada e formada por uma diversidade de arranjos familiares..."15

Esta citação relacionada a complexidade do projeto habitacional, pode fundamentar o aprofundamento do ensino da ergonomia como instrumental orientador do dimensionamento de ambientes habitacionais.

A resposta acadêmica a sociedade além da formação no futuro profissional está qualidade do projeto arquitetônico e consequentemente na usabilidade do espaço doméstico .

A interdependência entre as condições de conforto e as variações dimensionais, formam conjunto de informações que representam material de trabalho da disciplina AUT 5809 - Modelos de Dimensionamento dos Espaços das Habitações, do Curso de Pós Graduação -FAU USP que tem como responsável, o orientador desta pesquisa BOUERI, J.J. , fornecendo dados relevantes para se projetar e analisar com mais consciência e conhecimento os espaços habitacionais .

\footnotetext{
${ }^{14}$ Lemos Carlos A.,1999, passim A Casa Paulista.

${ }^{15}$ Id. 7 , pag. 3
} 


\section{Processo de Desenvolvimento: Referências Teóricas e}

Metodológicas

Os métodos aplicados nesta pesquisa incluíram diferentes abordagens lógicas para o projeto de investigação, assim como a escolha de diferentes técnicas de pesquisa, quais sejam;

- Definição do objeto de estudo e sua relevância, em conjunto com os orientadores e grupo de pesquisa o que propiciou uma complementação no objeto de estudo no decorrer do trabalho.

- O início do processo investigativo se deu com pesquisa bibliográfica, inserindo o objeto de estudo em um contexto histórico e cultural. Com a contextualização do dimensionamento habitacional em uma linha histórica de leitura, dentro do cenário mundial e posteriormente na cidade de São Paulo, através de plantas em escala gráfica.

- Os fundamentos teóricos utilizados visaram identificar as técnicas e os modelos de dimensionamento dos espaços da habitação, o estudo das funções e atividades desenvolvidas dentro do espaço doméstico e demais trabalhos que compõe o capítulo II.

- Seleção de material gráfico para pesquisa, inclui:

1. Desenhos promocionais dos apartamentos, retirados do Inventário BOUERI FAPESP.

2. Plantas de apartamentos antigos pertencentes aos arquivos da biblioteca da FAU USP.

3. Plantas de apartamentos retiradas da bibliografia específica. 
Este material formou um conjunto de desenhos que inseridos em uma linha de tempo, proporcionam uma leitura do dimensionamento dos compartimentos da habitação paulistana. Enfim, definido o significado da amostra escolhida e delimitando a área de abrangência do estudo.

- A sistematização e análise de dados colhidos com a aplicação dos métodos de avaliação de qualidade habitacional, foi realizada através da leitura de tabelas e gráficos comparativos.

- A etapa final foi a aplicação do método de avaliação de qualidade habitacional, do Prof. BRANCO J. P.(2003) $)^{16}$, em apartamentos dentro da mesma faixa de área privativa, facilitando a contextualização do apartamento no mercado imobiliário da cidade de São Paulo .A avaliação de qualidade conclui com um comparativo dos "Índices Ergonômicos, BOUERI, (2001)".

A pesquisa partiu da visão histórica da apropriação física do homem ao espaço edificado, com a finalidade de habitar, discorreu sobre a importância da escolha de critérios adequados para o dimensionamento dos espaços habitacionais utilizando como instrumental a ergonomia e das dimensões do corpo humano, e concluiu com uma avaliação dimensional de alguns exemplos de empreendimentos habitacionais pertencentes ao mercado imobiliário da cidade de São Paulo., que utiliza a área privativa dos apartamentos, associada a localização do imóvel na cidade como conjunto indexador de preço ou de valor.

${ }^{16}$ Lnec 


\section{Quadro Resumo da Estrutura da Dissertação}

\section{Capitulo I}

\section{A Evolução da Plantas das Habitações}

Este capítulo é uma coletânea de dados resumidos em uma seleção de plantas habitacionais, situadas em uma linha cronológica de tempo, sobre as quais foram geradas tabelas de uso e função relacionadas às dimensões dos compartimentos.

O estudo do Uso / Função x Dimensão, dos ambientes habitacionais foi realizado através de desenhos com dimensões retiradas de plantas uma linha de tempo, com a finalidade identificar os ambientes através da função e uso dos mesmos, dentro de um contexto histórico da habitação paulista nos últimos 300 anos.

\footnotetext{
Capitulo II

Qualidade Habitacional

O capítulo II tem por finalidade fornecer um embasamento teórico para o estudo da qualidade habitacional, verificando como vem sendo considerada e avaliada a dimensão dentro deste contexto e sua importância para a qualidade do projeto arquitetônico residencial.

Os trabalhos teóricos realizados citados, deram sustentação aos métodos utilizados, os quais forneceram dados para a escolha dos itens a serem avaliados e suas implicações expressas nas ponderações e critérios escolhidos.

Para este capítulo e o capitulo III, o presente trabalho teve a co-orientação do arquiteto pesquisador português do LNEC, PEDRO,João Branco., devido a linha de pesquisa por ele adotada que possibilitou o desenvolvimento de trabalhos conjuntos das duas entidades de ensino (CPG-USP e LNEC), visando um intercâmbio de dados e pesquisas, através de uma visão globalizada, porém não aleatória, graças às proximidades culturais advindas do relacionamento histórico, Brasil - Portugal. Este capítulo tem como finalidade fornecer dados para a clara compreensão dos métodos utilizados.
} 


\section{Capitulo III}

\section{Aplicação de Métodos de Qualidade Residencial em}

\section{Empreendimentos do Mercado Imobiliário na Cidade de São Paulo}

Nesta etapa do trabalho são aplicados os métodos descritos acima. O de PEDRO (2003) dentro das Exigências de Uso (aonde são avaliados todos os elementos que influenciam nas dimensões dos compartimentos habitacionais), aonde os resultados constam de tabelas e gráficos que explicitam os resultados obtidos, concluindo com as avaliação dos resultados obtidos. Posteriormente são aplicados os Índices Ergonômicos de BOUERI (2001), para o mesmo universo de apartamentos.

\section{Considerações Finais}

As considerações finais contêm comparações entre as diversas tipologias estudadas quanto à suas qualidades e deficiências, focando principalmente a capacidade de suportar as atividades previstas para cada ambiente residencial. Fornecendo material que poderá ser utilizado por projetistas, por outros agentes envolvidos no processo construtivo habitacional, desde agentes financeiros, e ou promotores habitacionais, até por futuros usuários do imóvel, como instrumento auxiliador nos momentos de tomada de decisões. 


\section{Capítulo I}

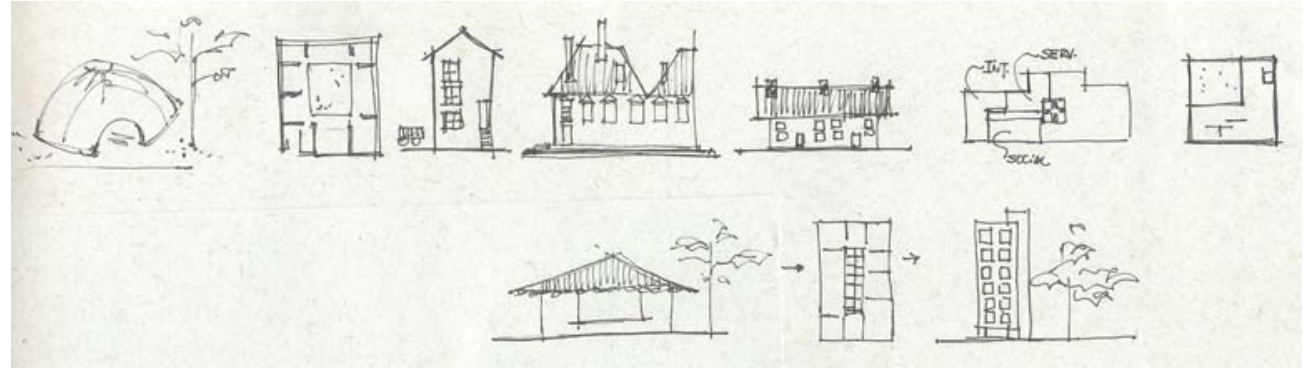




\section{Capítulo 1:}

\section{Evolução Histórica das Dimensões nas Plantas de Habitações.}

Este capítulo se destina ao estudo do espaço construído utilizado como moradia e suas dimensões em uma linha de tempo, em um período de aproximadamente 6000 anos. Os desenhos em escala gráfica das residências auxiliaram o estudo, possibilitando a comparação do dimensionamento dos ambientes ou espaços domésticos em várias épocas distintas.

A subdivisão deste capítulo é feita em duas partes e em ordem cronológica. Serão incluídos exemplos de casas, além dos apartamentos, fora e dentro do Brasil. Cabe salientar que o assunto não receberá um tratamento histórico, por não se tratar de um trabalho sobre história da arquitetura, mas sim sobre o homem e a sua apropriação do espaço para abrigo e moradia, tendo como ponto de partida o corpo humano e a "bolha envoltória", que segundo BOUERI ${ }^{1}$, surge como uma necessidade quando o homem se movimenta exercendo uma atividade.

Muitas construções foram identificadas como habitações pelos artefatos encontrados nas escavações ou mesmo nas ruínas das edificações. Assim, as plantas terão os usos e funções, estudados através dos objetos identificados pelos autores na primeira parte e pelo mobiliário desenhado nas plantas na segunda parte do capítulo.

A primeira parte é direcionada paras as habitações que deram origem aos apartamentos, iniciando com as habitações pré-urbanas, depois as habitações das civilizações da antiguidade, passando pelas habitações da idade média, e

\footnotetext{
${ }^{1}$ Pág. BOUERI,Jorge 1999 Antropometria Aplicada à Arquitetura e Urbanismo e Desenho Industrial, FAU USP.
} 
concluindo com a era moderna onde encontraremos um maior número de exemplos. Esta parte teve como base bibliográfica o livro de SCHOENAUER, Norbert W.W. 1981 -6,000 Years of Housing - Norton and Company- New York London (tradução do autor) - o texto só citará outros autores, ficando implícito que o conteúdo das informações é de autoria deste professor da escola canadense "McGill University Montreal, Quebec, Canadá". O mesmo é válido para as figuras. As tabelas são todas realizadas pelo autor, portanto a fonte não será citada em cada uma delas.

A segunda parte aborda exclusivamente as habitações paulistas, principalmente a transição dos moradores dos palacetes paulistanos da época do café para os apartamentos, focando da mesma forma o uso/função e dimensão os ambientes. 
1. Parte I

A Dimensão Das Habitações, Uma Visão Global

Independentemente da época de sua utilização, muitos tipos de construções, como as indígenas e dos esquimós, continuam existindo até hoje. Estas habitações refletem o tipo de vida de seus moradores, sua cultura e suas necessidades, descrevendo as várias formas em que o homem, na procura por alimento, demarca a natureza de suas habitações. Podem ser vistas também como uma resposta arquitetônica ao conjunto de fatores culturais, características ambientais e sócio-econômicas, fundamentando a teoria de que a similaridade destes conjuntos determina a similaridade nas formas das construções habitacionais, podendo ser exemplificadas como segue:

\section{A Casa Pré Urbana}

A tipologia da habitação é definida pelo fator tempo de ocupação pelo homem em espaço abrigado. Desse modo, as casas pré-urbanas podem ser divididas em seis tipos²:

Habitações Transitórias ou Efêmeras.

Habitações Temporárias Irregulares.

Habitações Temporárias Periódicas ou Regulares.

Habitações Sazonais.

Habitações Semipermanentes.

Habitações Permanentes

Nesta pesquisa serão apresentados três tipos de forma simplificada, a saber:

1. Habitações Temporárias

2. Habitações Semi-Permanentes

3. Habitações Permanentes

${ }^{2}$ Segundo SCHOENAUER, Norbert W.W. 1981 "6,000 Years of Housing" Norton and CompanyNew York - London (tradução do autor) - o texto de agora em diante citará esta fonte bibliográfica apenas SCHOENAUER. 
As Habitações Temporárias são aquelas utilizadas por um período

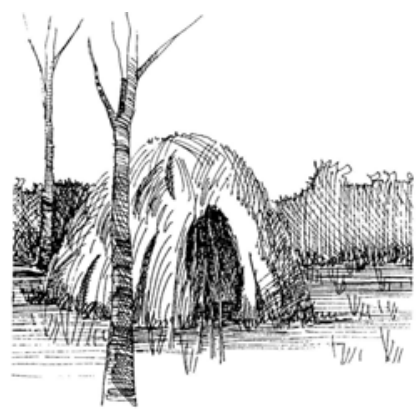

Fig.I 01-Exemplo de Habitação Temporária

AFRICAN BUSHMEN SKERM

Fonte| SCHOENAUER de tempo relativamente pequeno $\mathrm{e}$ quantificável, que poderá variar de 1 dia até 6 meses $^{3}$.

\subsection{Habitações Temporárias}

Transitórias

As habitações transitórias são pequenas, com estrutura em domo, não possuem janelas ou aberturas para a saída de fumaça, somente um vão de entrada, sem porta ou paredes verticais.

Os habitantes eram coletores e caçadores, caracterizando-se por andar em bandos ou sendo nômades. O estilo de vida representa uma cultura da Idade da Pedra Antiga que sobreviveu até hoje, a partir de 8.000 a.C. Este tipo de habitação é encarado com algo bem distante da nossa época, porém, existe até hoje.A figura 03 apresenta uma área de $5,00 \mathrm{~m}^{2} \mathrm{com}$ a função de guarda de objetos e abrigo.

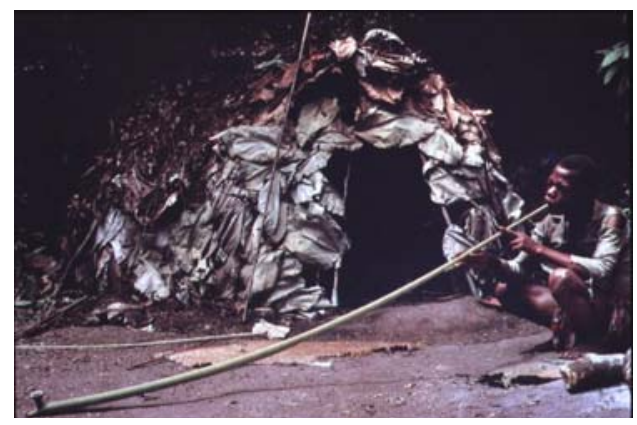

Fig.I 02-Habitação do Temporária BAMBUTI PYGMY HUT

Fonte-http://www.arch.mcgill.ca/prof/schoenauer

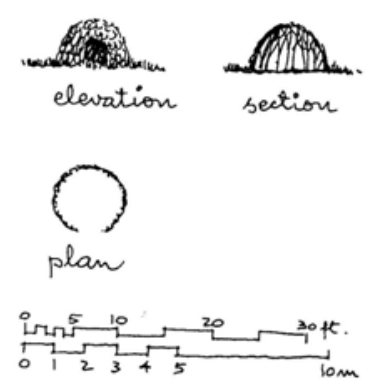

Fig.I 03-Habitação do Temporária BAMBUTI PYGMY HUT Fonte: SCHOENAUER

${ }^{3}$ SCHOENAUER 1981, passim. 


\subsection{Habitações Temporárias Regulares e Irregulares}

Os habitantes são bandos ou tipos de sociedades cuja existência depende de caça mais elaborada ou de plantio básico. Essa pode ser considerada a etapa inicial do pastoreio e da agricultura rudimentar e sua característica é a utilização da forma circular, variando o material, que pode se constituir de madeira a blocos de gelo. Os ambientes são divididos por funções ou famílias.

Exemplos:

1.2.1. Inuit Igloo - Iglu dos Esquimós

Habitações compostas por módulos circulares em forma de domo ligados por túneis. As casas de neve eram para uma família e, em alguns territórios, podiam ser encontradas várias famílias no mesmo iglu , cabe salientar que o conceito de família é muito diferente do mundo ocidental, principalmente o papel feminino.

O iglu era constituído de ambientes para a guarda de

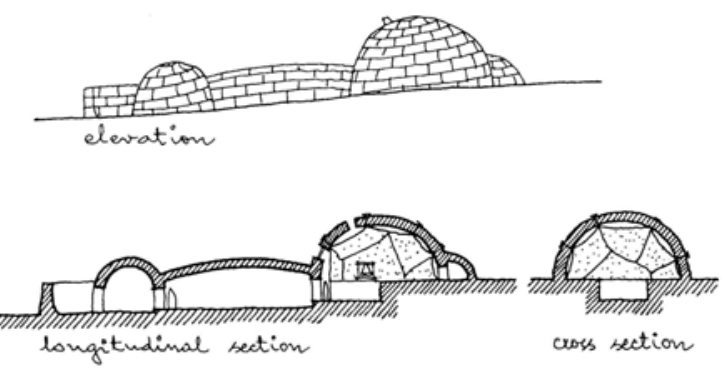
encontrado até hoje. O iglu da figura 4 tem aproximadamente $30,00 \mathrm{~m}^{2}$.

\section{USO/FUNÇÃO}

guarda de alimentos, descanso (dormir) e estar.

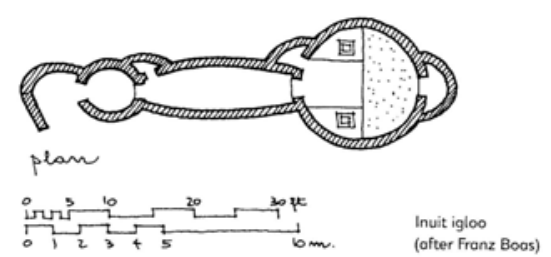

Fig.I 04- Elevação, Corte Longitudinal e Planta INUIT IGLOO Fonte: SCHOENAUER 

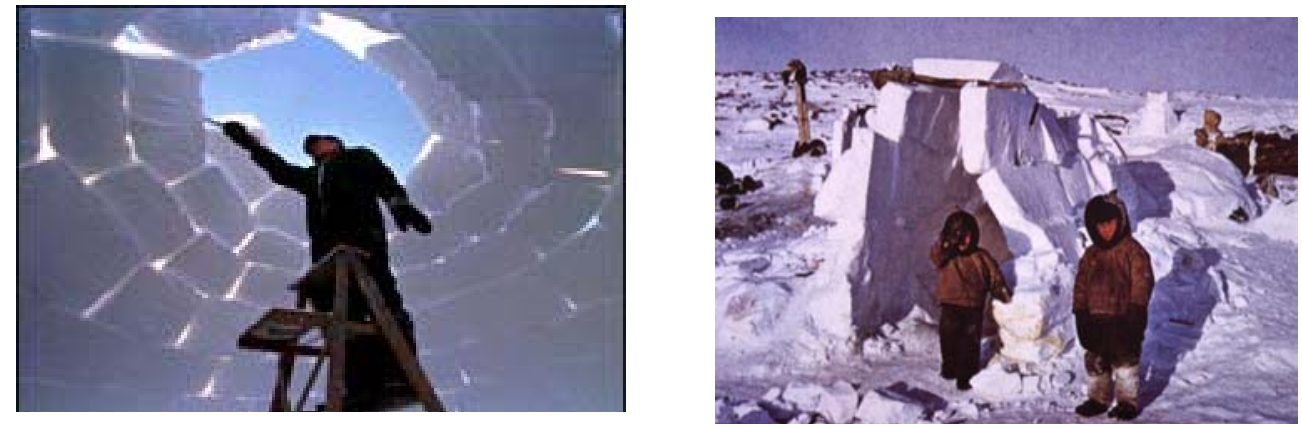

Fig.I 05- Imagens Ilustrativas INUIT IGLOO

Fonte http://www.hh.schule.de/ngb/ltb/ltb-02/lglubau.jpg http://www.msnbc.msn.com/id/3917289/ 15/02/2007

\subsubsection{Maloca dos Cubeo e Erigbaagtsa - Amazonia}

As Malocas são habitações comunitárias de forma oval; cobertura e paredes cobertas com babaçu; não tem janelas e as entradas são fechadas com espessos painéis de folhas. São habitadas por tribos que cultivavam, caçavam, pescavam, cortavam madeira e pegavam água. O ambiente é único, sendo que os pilares dividem o espaço de cada família; a parte central é reservada para cultos; o jantar é preparado em uma cozinha comum, o ambiente é utilizado como proteção, descanso e para alimentação, englobando área aproximada de $257,00 \mathrm{~m}^{2}$.para aproximadamente 6 famílias.

\section{USO/ FUNÇÃO}

- Cultos religiosos e sociais

- Prática da dança

- Proteção

- Dormir (dormitório)

- Alimentar (Alimentação).

Fig.I 06 Elevação e Planta CUBEO MALOCA

Fonte SCHOENAUER,com indicações do autor

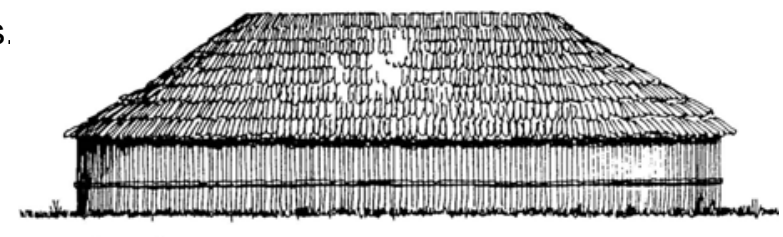
elevation

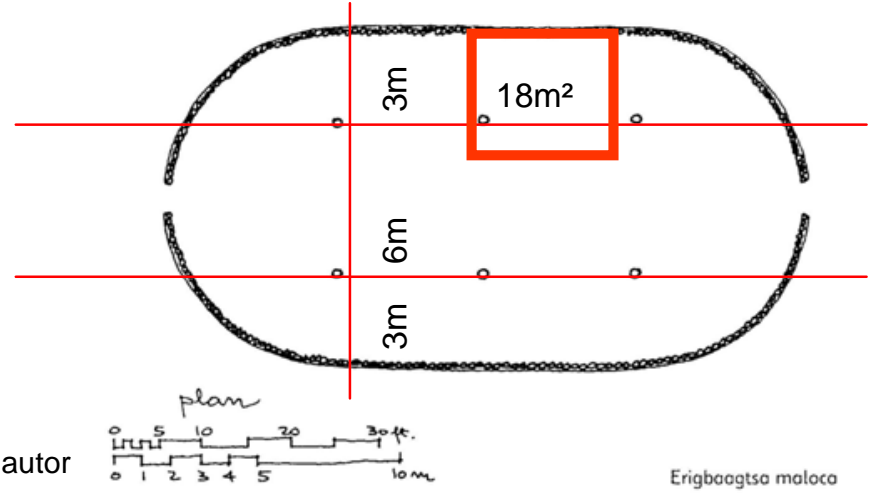




\subsection{Habitações Semi-Permanentes}

O segundo estágio em estudo inclui abrigos semi-permanentes e habitações de sociedades sedentárias. Estes agricultores têm que deixar suas terras quando estas estão exauridas, influenciando assim diretamente na tipologia de suas habitações. De acordo com o tipo de cultivo, o uso das moradias variava de poucos anos, podendo chegar até 15 anos. O material empregado nas construções foi se tornando mais durável, adquirindo elementos mais elaborados para atender às novas necessidades. Existe a necessidade de estocagem de grãos para períodos de entressafra.

\subsubsection{Mesakin Quisar Cluster}

É um povo que vive no Sudão em abrigos de formas circulares, cada unidade é formada por 5 ou 6 cabanas com telhados cônicos e paredes de adobe. Sobrevivem de atividades agrícolas como o cultivo de milho. A colheita é feita pela comunidade e é armazenada em uma das células da casa. A pecuária é de sobrevivência e uma curiosidade é o fato de as crianças dormirem na mesma célula dos porcos.

Tabela 1 - Mesakin Quisar Cluster

\begin{tabular}{l|c|c}
\hline \multicolumn{1}{c|}{ AMBIENTE } & USO/ FUNÇÃO & ÁREA $\left(\mathrm{m}^{2}\right)$ \\
\hline & Acesso/ Distribuição & \\
\hline PÁTIO INTERNO & Reuniões/Cozinhar/ & 45,00 \\
\hline & Preparo de Alimentos & \\
\hline CABANA DO CASAL & Repouso/Abrigo & 9,00 \\
\hline CABANA MILHO & Dormitório Meninas & 9,00 \\
\hline & Estocagem grãos & \\
\hline CABANA DEPÓSITO & Estocagem & 9,00 \\
\hline CABANA DE ANIMAIS & Estocagem & 9,00 \\
\hline
\end{tabular}




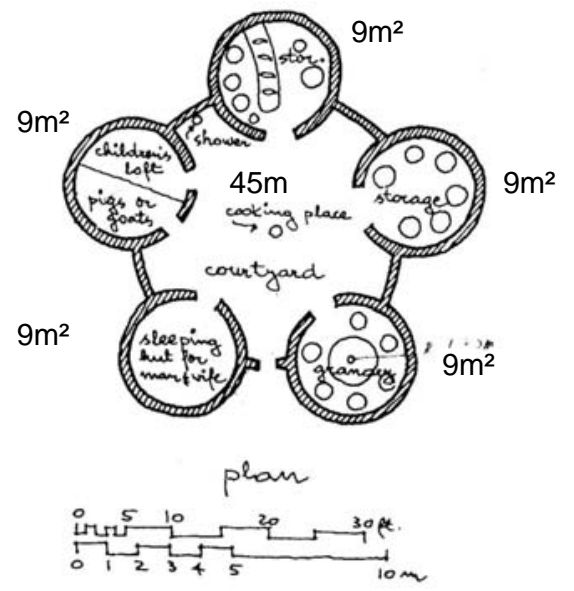

Fig. I 07 -Planta Mesakin Quisar Cluster

Fonte: SCHOENAUER

Com indicações do autor

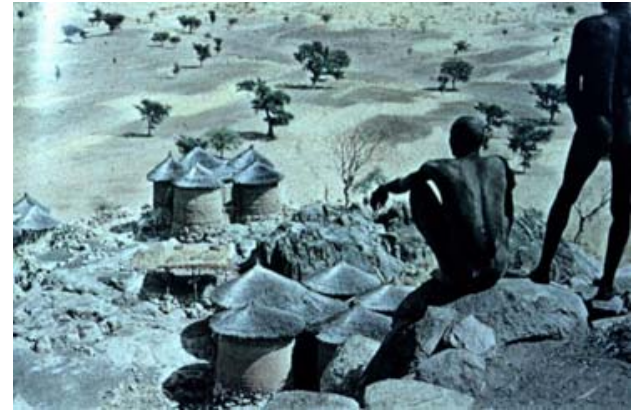

Fig.I 08 Imagens Ilustrativas Mesakin Quisar Cluster http://www.arch.mcgill.ca/prof/schoenauer/arc h528/lect03/b03.jpg

\subsubsection{Pueblos}

Os Pueblos são habitações semipermanentes coletivas de tribos indígenas localizadas nos platôs semidesertos do Arizona e do Novo México. As habitações são em terraços, com múltiplos pavimentos (de 3 a 5) e cumulativas na maioria das vezes. Elas vão agregando ambientes às habitações existentes e outras unidades habitacionais formando uma praça central. A sociedade é matriarcal. Vivem do plantio, em terras de difícil manuseio, utilizando o escoamento de um platô para outro. Até os dias de hoje alguns povos indígenas preferem seus arados rudimentares da época pré-colombiana.
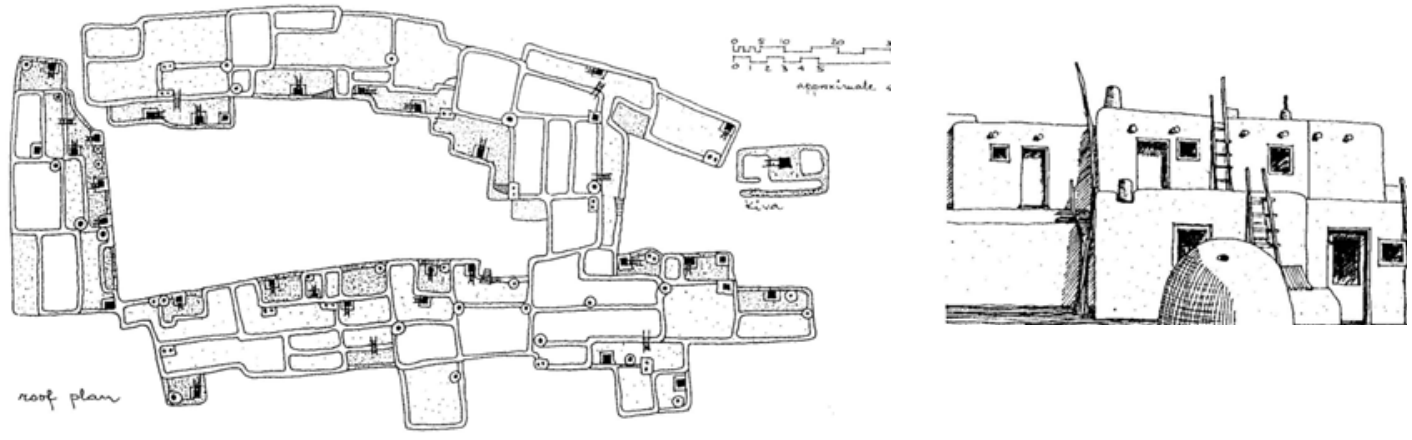

Fig. I 09 Implantação e Vista Pueblos

Fonte: SCHOENAUER 


\subsection{Habitações Permanentes}

O grupo das habitações permanentes é formado pelas habitações das sociedades com desenvolvimento agrícola mais avançado. Estas habitações podem ser usadas por muitas gerações. A unidade de organização social é a família.

Agricultura com produção de excedentes cria rotas para outros mercados. As conseqüências desta evolução poderão ser sentidas com o enfraquecimento dos laços de parentesco e na paisagem natural com a devastação das matas nativas e as erosões.

Existem várias tipologias de moradias permanentes, de cavernas a complexos de construções em fazendas. A tipologia das habitações vai variar de acordo com o clima, a topografia e a herança cultural, entre outros. Podem-se citar como características comuns:

- os materiais duráveis (madeira / pedra / alvenaria), elementos mais elaborados como portas, janelas e chaminés, A climatização visa o conforto e não só a sobrevivência, os ambientes são maiores e com usos definidos (repouso / estar/ preparo de alimentos). O uso de materiais característicos de uma determinada região resulta em construções típicas que, combinadas às necessidades climáticas, produzem desenhos específicos, criando diferentes tipologias de moradias permanentes em cada região.

\subsubsection{Chinese Cave}

Aproximadamente 40 milhões de chineses vivem em zonas rurais, descendentes de civilizações agrícolas da antiguidade. As habitações são cavernas com vários compartimentos voltadas para um átrio de 9x9m. Esta configuração visa proteger dos fortes ventos de invernos e garante temperatura mais agradável no verão, com alto padrão de conforto e higiene e possuem orientação solar. Existem 2 tipos diferentes dessas habitações: as nas escarpas das montanhas e as escavadas nos platôs. 


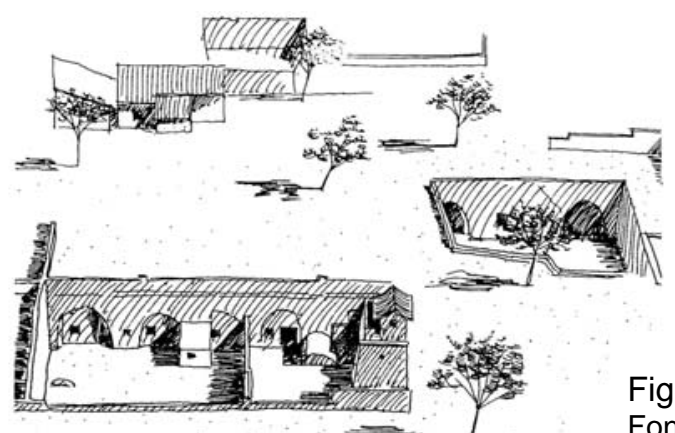

Fig.I 10 Cavernas Chinesas - Vista Fonte: SCHOENAUER

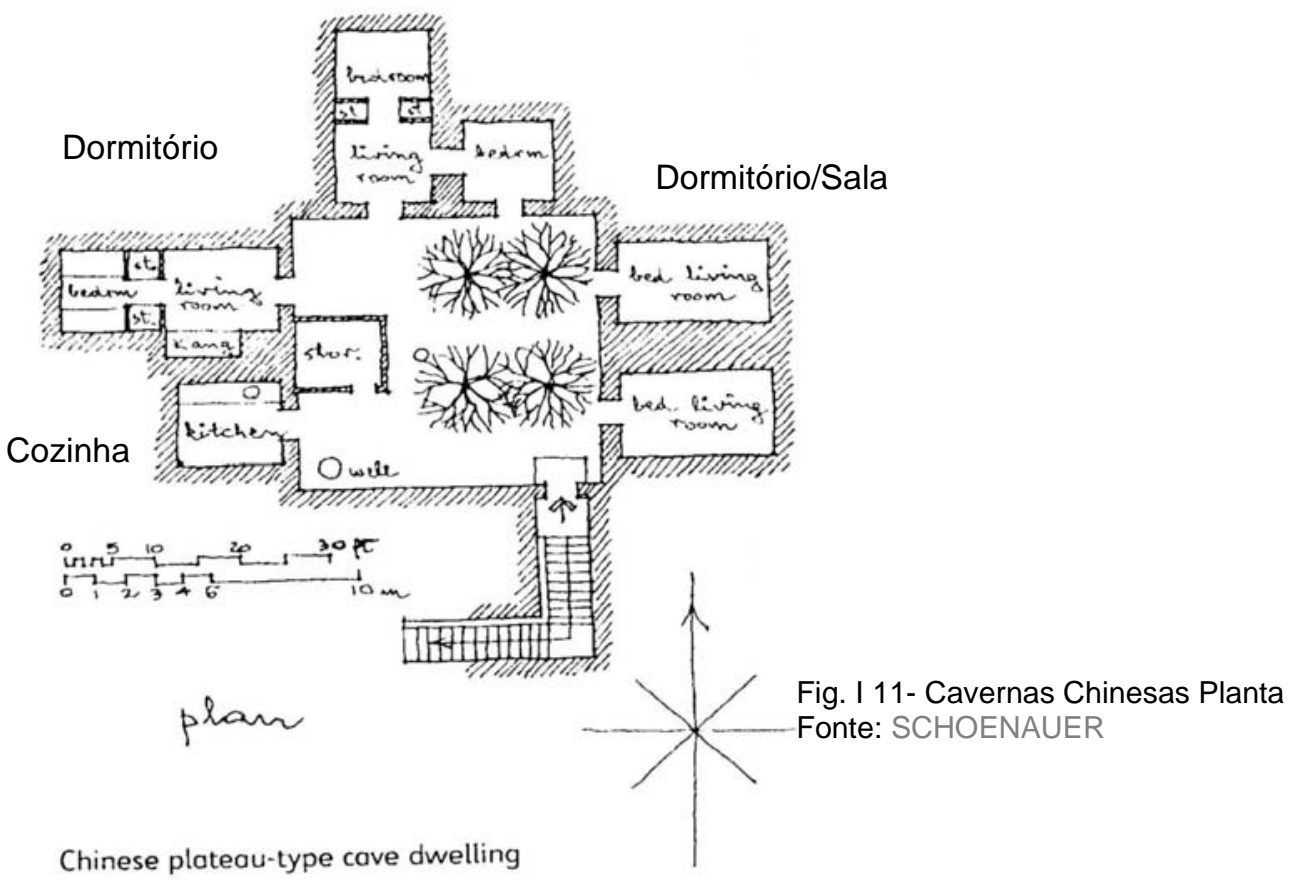

Tabela 2 - Chinese Cave

\begin{tabular}{l|c|c}
\hline \multicolumn{1}{c|}{ AMBIENTE } & USO/FUNÇÃO & ÁREA $\left(\mathrm{m}^{2}\right)$ \\
\hline $\begin{array}{c}\text { PÁTIO } \\
\text { DESCOBERTO }\end{array}$ & $\begin{array}{c}\text { Acesso/ } \\
\text { Reuniões } \\
\text { Estocagem }\end{array}$ & 45,00 \\
\hline DORMITÓRIOS & Repouso/Abrigo & 19,50 \\
\hline $\begin{array}{l}\text { DORMITÓRIOS / } \\
\text { SALA }\end{array}$ & Repouso/Estar & 16,50 \\
\hline COZINHA & Preparo de & 9,00 \\
\hline
\end{tabular}




\section{A Casa das Civilizações da Antiguidade}

A segunda parte deste capítulo, trata das civilizações da antiguidade como a da Mesopotâmia, da Babilônia, da Assíria, a civilização grega e romana, incluindo ainda as casas tradicionais Islâmica, Hindu e Chinesa, seguindo a ordem cronológica apresentada por SCHOENAUER ${ }^{4}$.

As casas urbanas da antiguidade apresentavam características parecidas. Os núcleos urbanos, onde estavam implantadas nasceram ao logo do vale de rios. São casas com uma tipologia conhecida como "Casa Pátio". Os ricos e pobres moravam lado a lado nestas cidades. A diferença entre as casas dos ricos e pobres está no tamanho, na dimensão.

A civilização helênica nos deixou uma excepcional concepção de casas, elas mantêm os pátios internos das casas gregas, porém, agora com pilares "Persytle". O tamanho das casas não é exagerado e o principal ambiente é a sala de jantar.

O império romano nos deixa exemplares residenciais importantes. A cidade de Pompéia e as obras de Vitruvius são um exemplo.Temos também as casas das classes menos favorecidas os "Insuales", tipos de cortiços, com até 5 andares, construções mal executadas e que chegavam a ruir matando seus moradores.

Os exemplos apresentados facilitam a compreensão do dimensionamento dos ambientes das casas. A palavra em inglês "spirit wall" (não será traduzida) utilizada pelo professor SCHOENAUER, identifica a parede oposta à porta de entrada, com a função de manter a privacidade e um significado simbólico de barrar os maus espíritos (daí a sua denominação), a repetição seguida deste termo se deve ao fato de existir esta preocupação em diversas culturas, com distancias geográficas significativas.

\footnotetext{
${ }^{4}$ SCHOENAUER,1981 passim.
} 

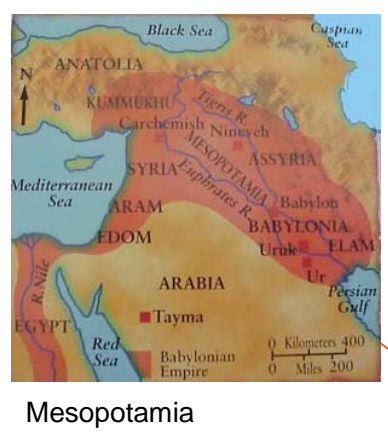

Babilônia, Assíria Egito
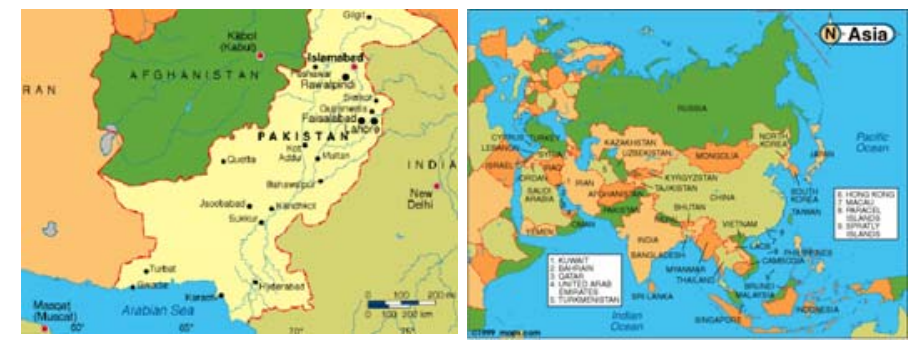

Índia - Mohenjo-Daro China e Japão

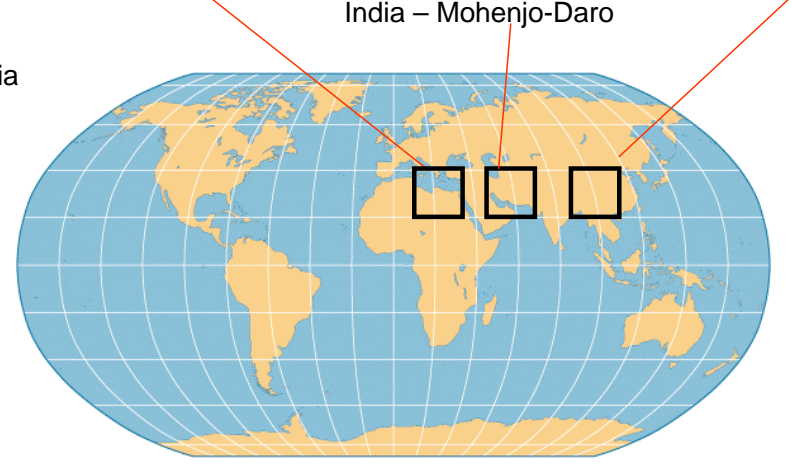

Fig.I 12-Mapa de localização dos exemplos Fonte-autor

\subsection{Mesopotâmia - Sumérios}

A terra entre os rios os vales férteis dos rios Eufrates e Tigre é que determinaram a localização destas civilizações urbanas, inicialmente a fertilidade do solo e posteriormente a navegabilidade dos rios, facilitando o comercio. Os Sumérios, civilização que data de 3500 a.C., era formada por várias cidades-estado (administradas pelo rei e pela casta de sacerdotes), com alto grau de organização social, sendo o primeiro povo a usar o ouro e prata como padrão de valor. A escrita cuneiforme foi desenvolvida e criada para organizar a contabilidade. O trabalho comunitário, as plantações irrigadas por canais e os vales férteis permitiram o excedente de produção agrícola, que por sua vez, viabilizou o abastecimento dos artesãos, dando início à formação de áreas urbanas. Os escritórios e oficinas de artesãos tinham uma tipologia similar às residências. As cidades sumérias mais importantes foram; Eridu, Uruk, Ur, Larsa e Nippur, porém a cidade de Ur (época áurea de 2474 a 2398 
a.C.) é a que nos traz mais informações sobre a forma física das habitações urbanas da Suméria, tida como a cidade de Abraão (profeta bíblico). Ocupava uma área de 89 hectares com 34.000 habitantes. A casa em Ur era aglutinante e formada por vários compartimentos em torno de um pátio central descoberto. A separação nítida do espaço para o público e para a família é uma característica marcante e o pátio interno descoberto é uma constante unindo todos os outros ambientes, tanto de moradia como de trabalho.

Os ambientes têm forma regular e o material empregado nas construções, por falta de disponibilidade de pedras, foi a alvenaria de tijolos de adobe.

O acesso às residências é feito por ruas estreitas, onde os ricos moram muitas vezes ao lado dos pobres, pois as casas eram todas voltadas para dentro, introspectivas. Os vestíbulos com as "spirit walls" sempre guardavam a privacidade dos moradores. O local de trabalho sempre era junto do local de moradia.O "Código de Hamurabi " foi feito nessa época, e no que diz respeito às construções, pode-se dar o seguinte exemplo:

"um arquiteto constrói uma casa para alguém, porém não a faz sólida, resultando daí que a casa venha a ruir e matar o proprietário, este arquiteto é passível de morte.Se ao desmoronar, ela mata o filho do proprietário, matar-se-á o filho deste arquiteto" 5 .

2.1.1.Casa 2 período de Lars na cidade de UR - de 1900 a 1800 a C.

Com área total de $228 \mathrm{~m}^{2}$, incluindo os pátios internos e tendo o maior ambiente com área de $15,00 \mathrm{~m}^{2}$ sem uso definido.

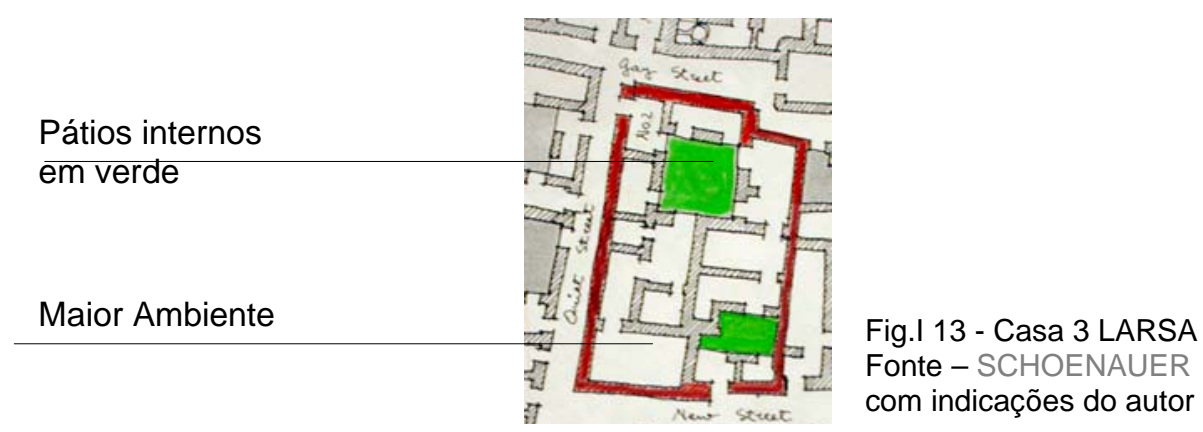

${ }^{5}$ AQUINO, R. \& Outros 1982 pág. 114 . História das Sociedades. das Comunidades Primitivas às Sociedades Medievais. Rio de Janeiro, Ao Livro Técnico S/A, 


\subsection{Egito}

No norte da África, no vale do rio Nilo, a civilização egípcia data de 5000 aC. a 3100 aC., época da unificação do Alto e do Baixo Egito. As principais construções eram os túmulos dos Faraós. As melhores informações sobre as residências dessa fase foram encontradas nas residências dos trabalhadores das construções destes túmulos. O antigo Egito se desenvolveu ao longo do Nilo. O controle da irrigação e a divisão de trabalho foram fatores que facilitaram a criação de centros urbanos. Contavam com a força de trabalho escravo. Realizavam trabalhos em cerâmica e metal e desenvolveram escrita própria. A planta da casa dos trabalhadores, apresentada como exemplo, é modular e com pátios internos, constituída por 2 andares. As casas eram geminadas com 2 ou 3 módulos dentro de um mesmo padrão, sugerindo uma hierarquia dos trabalhadores. No exemplo de "Deir Medina"(fig.I 14), o material empregado era (constituído por) blocos cerâmicos secos ao sol e a cobertura era feita com uma trama de folhas de palmeira recoberta de terra, onde se destacavam janelas junto ao teto.A técnica construtiva é diferente da usual entre os egípcios, que se destacaram por construções em pedra.

\subsubsection{A Casa Deir El Medina 1540-101aC}

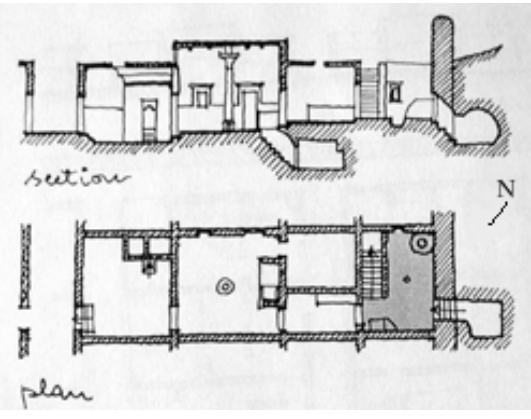

Tabela 3 Casa Deir El Medina Fonte: autor

\begin{tabular}{c|c|c}
\hline AMBIENTE & USO/FUNÇÃO & ÁREAS(m2) \\
\hline HALL/ ENTRADA & Acesso /Religoso & $4,00 \times 5,50$ \\
\hline HALL /PRINCIPAL & Estar/Distribuição & $5,00 \times 5,50$ \\
\hline DORMITÓRIO & Repouso/Dormir & $3,20 \times 2,50$ \\
\hline SUBSOLO & Não indicado & $1,50 \times 1,50$ \\
\hline
\end{tabular}

Fig.I 14 - Casa DEIR EL MEDINA 1540-101aC Fonte: SCHOENAUER 


\subsubsection{Casa Dupla Khaun}

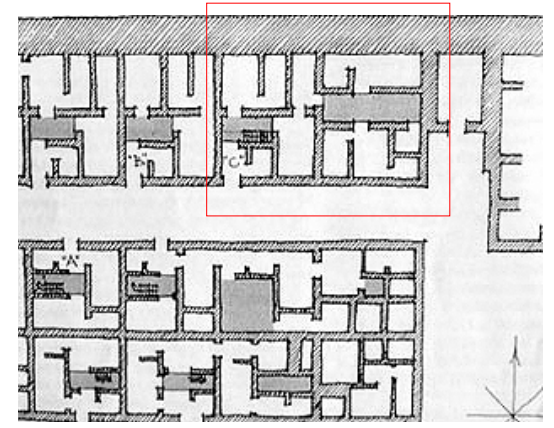

Fig.I 15 Casa Dos Trabalhadores KAHUN Fonte: SCHOENAUER

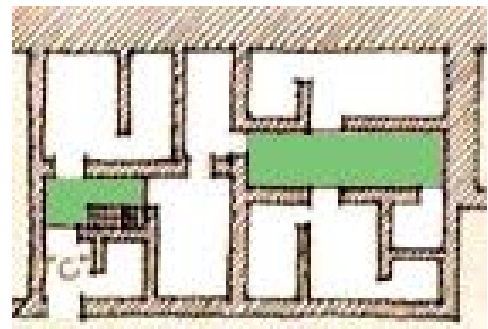

Fig. I 16 Casa C KAHUN

Fonte: SCHOENAUER

Com indicacões do autor

Tabela 4 Casa Dos Trabalhadores KAHUN Fonte: autor

\begin{tabular}{c|c|c}
\hline AMBIENTE & USO/FUNÇÃO & ÁREA $\left(\mathrm{m}^{2}\right)$ \\
\hline Vestibulo & Acesso & $2,00 \times 2,00=4,00$ \\
\hline $1^{\circ}$ ambiente & indefinido & $3,00 \times 4,00=12,00$ \\
\hline $\begin{array}{c}2 \text { Pátios } \\
\text { Internos }\end{array}$ & Circulação/Ventiação & $7,50 \times 2,00=15,00$ \\
\hline \multicolumn{2}{|c}{} \\
\hline
\end{tabular}




\subsection{Mohenjo - Daro Índia 3250 a 2750 Ac}

As escavações na cidade de Mohenjo - Daro, Índia às margens do rio Hindus, também nos trouxeram valiosas informações sobre a cultura Hindu e a vida urbana que desenvolveu. Cultivavam cereais, possuíam veículos com rodas puxados por animais, praticavam comércio com a Mesopotâmia após 2.800 a.C., possuíam um sistema de leis e um padrão de vida confortável. Domesticavam animais; búfalos, camelos, elefantes, galinhas, porcos e cães; não conheciam gatos e cavalos. Produziam cerâmicas e ferramentas, assim como utensílios domésticos de bronze e prata.

Encontraram-se vestígios de banheiros com sistema de drenagem para fossas e locais para retirada de lixo junto às portas de entrada. Muitas casas tinham seus próprios poços, feitos com blocos de tijolo cozido. Foram encontradas várias escadas que indicavam a existência de um segundo pavimento. As habitações também eram introspectivas: possuíam vestíbulos dotados de "spirit wall", com a função de separar o público do privado e dos demais compartimentos, voltados para um pátio interno descoberto, formando cidades de ruas estreitas.

\subsubsection{Casa 54 - Mohenjo Daro}

Um exemplo típico de uma casa urbana pequena de Monjero Daro é a casa 54 , com área total $=78,00 m^{2}$, o pátio interno tem a função de conexão entre os ambientes, além da ventilação e iluminação.

Tabela 5 Casa 54 Mohenjo DARO

\begin{tabular}{l|c|c}
\hline AMBIENTE & USO/ FUNÇÃO & ÁREA $\left(\mathrm{m}^{2}\right)$ \\
\hline VESTÍBULO EM L & Acesso/ Distribuição & $9,00 \times 1,20=10,80$ \\
\hline PÁTIO INTERNO & Reuniões/Cozinhar/ & $4,00 \times 4,00=16,00$ \\
\hline $1^{\circ}$ AMBIENTE & Descanso (est.) & $2,00 \times 3,00=6,00$ \\
\hline PAV. EM & Cozinhar ( est.) & Irregular $=8,81$ \\
\hline
\end{tabular}

\footnotetext{
${ }^{6}$ Termo utilizado por SCHOENAUER fazendo referencia a parede oposta a porta de entrada, que será repetido no texto sem tradução.

${ }^{7}$ (Est.) - uso estimado por SCHOENAUER
} 


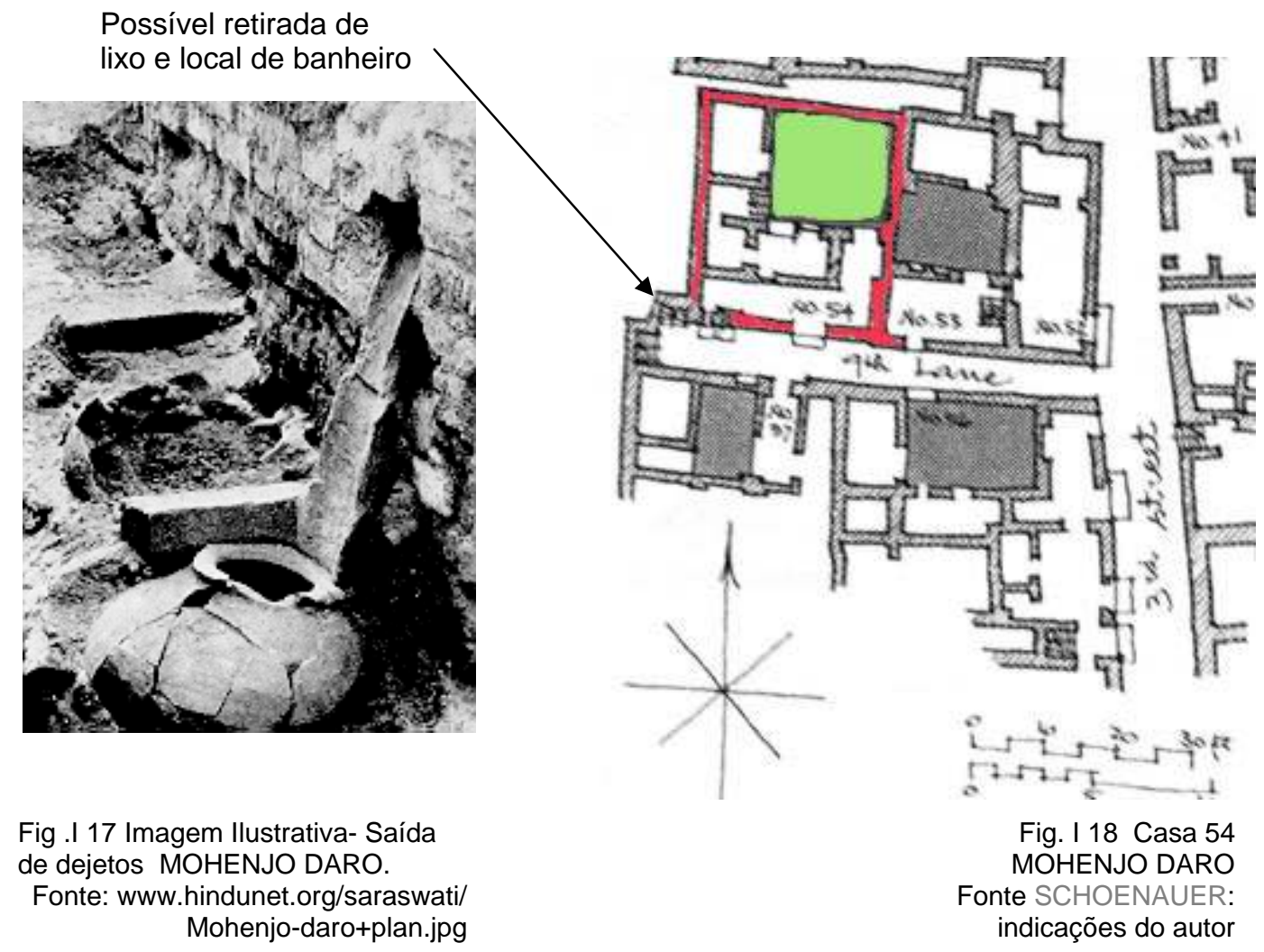

\subsubsection{Casa 8 - Mohenjo Daro}

Caracteriza-se também pela projeção irregular, com a indicação de mais de um pavimento (escada) e grande diversidade de ambientes. O vestíbulo é mais largo que a rua, possui um tipo de portaria, que faz às vezes da "spirit wall" (separando o público do privado) e conduz ao pátio interno, através de passagem estreita. $\mathrm{O}$ apartamento de hóspedes tem três ambientes e acesso independente direto do vestíbulo. Importante notar a zona que hoje chamamos de molhada, próxima ao poço com passagem para jarros junto ao banheiro. $\mathrm{O}$ piso do banheiro era pavimentado com tijolos, possuía uma abertura para o exterior, encontraram-se indícios de uma banheira e eram providos de canalização de esgoto. Existe também uma passagem do banheiro para a cozinha, possível passagem de água quente, segundo o autor. 
Tabela 6 Casa 8 MOHENJO DARO

\begin{tabular}{l|c|c}
\hline AMBIENTE & FUNÇÃO/ USO & ÁREA $\left(\mathrm{m}^{2}\right)$ \\
\hline \multirow{2}{*}{ VESTÍBULO EM L } & Transição Público/ Privado & \multirow{2}{*}{$9,00 \times 1,20=10,80$} \\
\cline { 2 - 2 } & Acesso & 80,00 \\
\hline PÁTIO EM L INTERNO & Distribuição/ Lazer & $4,00 \times 5,00=20,00$ \\
\hline MAIOR AMBIENTE & Estar /descanso/ privado & \multirow{2}{*}{ HANHEIRO } \\
\hline BANHe & $4,00 \times 3,50=18,00$ \\
\hline
\end{tabular}

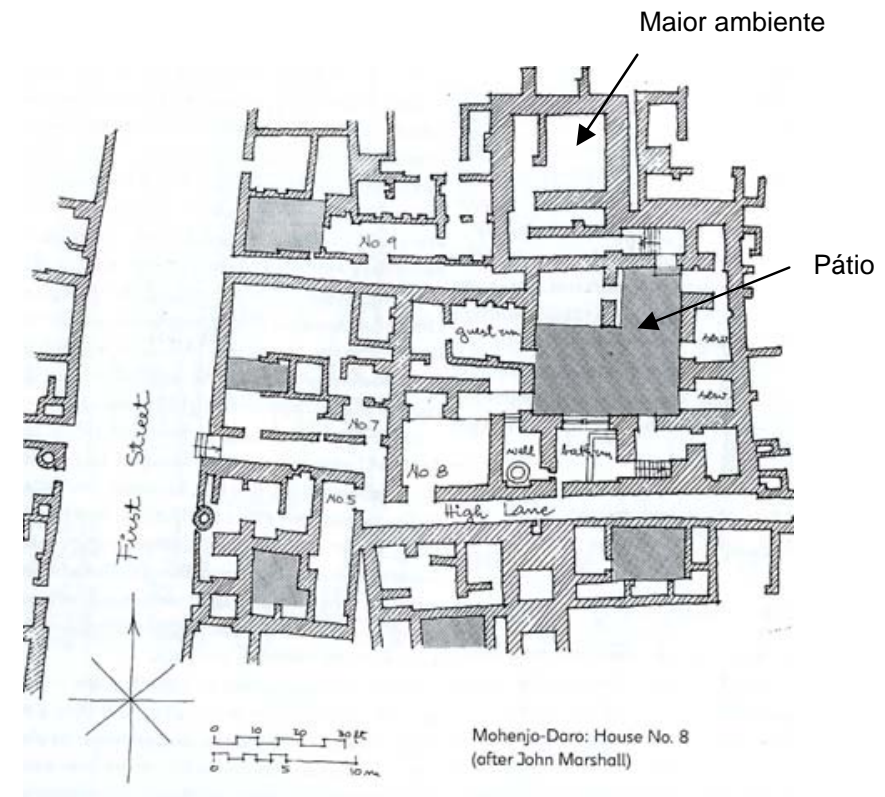

Fig. I 19 Planta Casa 8 MOHENJO- DARO

Fonte: SCHOENAUER, com indicações do autor

\subsection{A Casa Urbana Da Babilônia e Assíria 687 a 637aC}

O conjunto formado por 25 casas descobertas por Preusser (1954), em Assur, formavam um novo quarteirão, bem mais recente, porém guardavam as mesmas características das casas da Mesopotâmia.

\subsubsection{Red House das casas}

Um exemplo representativo deste período é a chamada "Red house" - a maior do conjunto, possuía dimensões avantajadas, forma irregular com dois pátios internos, inúmeros ambientes com forma retangular, entrada rodeada 
possivelmente por dormitórios de empregados domésticos, dois pátios internos descobertos e área íntima o mais longe possível da entrada.

Tabela 7 - Red House Assur

Fonte: autor

\begin{tabular}{l|c|c}
\hline \multirow{2}{*}{ AMBIENTE } & FUNÇÃO/ USO & \multirow{2}{*}{ ÁREA $\left(\mathrm{m}^{2}\right)$} \\
\hline \multirow{2}{*}{ Vestíbulo } & Transição Público/ Privado & \multirow{2}{*}{8,25} \\
\cline { 2 - 2 } & Acesso & \\
\hline Sala de Visitas & Receber / .A. Pública & 40,00 (total) \\
\hline Pátios Internos & Iluminação e Ventilação & 60,00 \\
\hline \multirow{2}{*}{ Cozinha } & Prep. de Alimentos/ & \multirow{2}{*}{15,00} \\
\cline { 2 - 2 } & Serviços & \multirow{2}{*}{34,00 (cada) } \\
\hline 2 salas de famíla & Estar / Privado & 8,00 ( cada) \\
\hline 3 dormitórios & Repouso / Privado & $22,00(4$ células cada) \\
\hline Banheiros & Higiene / Privado/trabalho & 56,00 (total) \\
\hline 4 escritórios & Trabalho /Público & \multirow{2}{*}{}
\end{tabular}

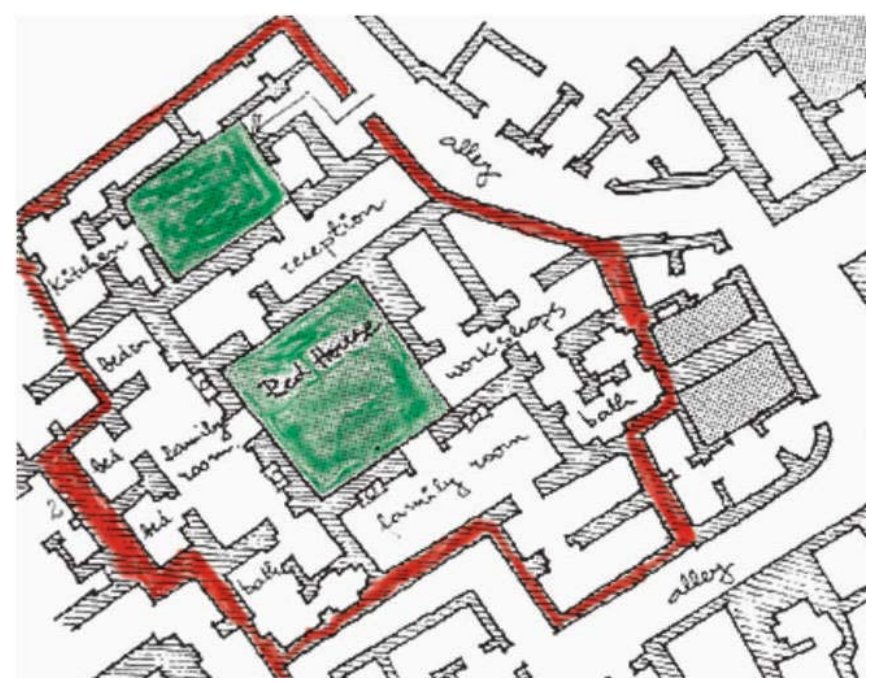

Fig. I 20 Planta Red House Assur

Fonte: SCHOENAUER, com indicações do autor 


\subsection{As Casas Gregas e Romanas}

\subsubsection{GRÉCIA - Helênica e Helenística}

O período clássico do desenvolvimento urbano na Grécia envolve o período de 900 a 600 a.C. A Fase considerada áurea em Atenas foi com Péricles de 443 a $429 a C$.

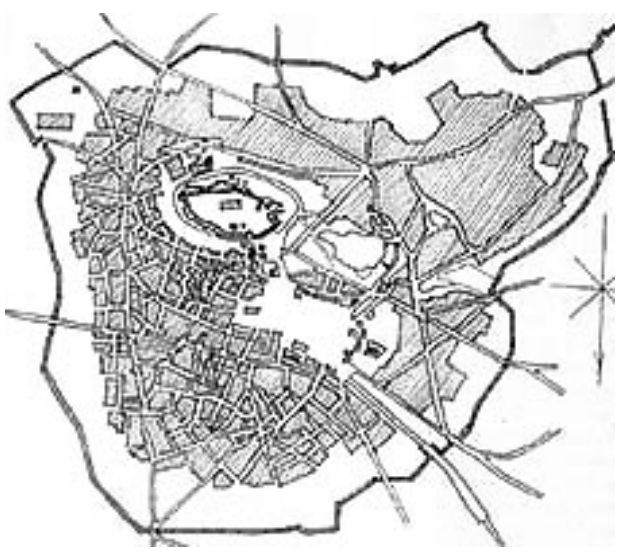

Fig. I 21 Cidade de Atenas Fonte: SCHOENAUER

A civilização helênica se desenvolveu junto com a Polis ${ }^{8}$ tendo o seu período próspero após a expulsão dos Persas. Criou uma sociedade urbana, entre os quais viviam filósofos e cientistas que nos deixaram entre os seus legados uma excepcional concepção de casas.

A composição social tinha características singulares: todo cidadão tinha a sua casa voltada para os pátios internos e dentro deste domínio as famílias viviam e trabalhavam; as mulheres eram totalmente segregadas, o que justificou a existência de compartimentos específicos dentro das casas (Ex."Oecus " quarto feminino ao lado da cozinha e do banheiro). É importante notar que as plantas destas casas já não possuem a parede de vedação nos vestíbulos de entrada, a "spirit wall".

\footnotetext{
${ }^{8}$ Poli - cidade pág. 1595 - 1999 FERREIRA, Aurélio B. de H. , séc. XXI Dicionário da Língua Portuguesa.
} 
Os costumes familiares peculiares influenciaram na distribuição e dimensão dos compartimentos, por exemplo: a comida era ou cozida em fogão aberto, as mesas eram montadas para as refeições e posteriormente desmontadas; comer sozinho era considerado barbaridade (notar a importância e conseqüente dimensão avantajada deste ambiente), as boas maneiras à mesa eram indicação de cultura. A família comia reunida quando não tinha visitas - quando um convidado masculino chegava, a mulher se retirava para um setor íntimo da casa.

As cidades tinham uma política de controle de crescimento, ecologicamente limitada pela capacidade de produção de alimentos. As cidades gregas, diferentemente das demais cidades das civilizações antigas não possuíam solos férteis nas margens dos rios.

As casas urbanas em geral eram pequenas e democraticamente simples, com um pavimento. Os pátios internos eram circundados por arcos "Peristyle", que eram itens marcantes na distribuição dos cômodos dessas residências, localizados na parte sul das casas, para que os principais quartos tivessem uma boa insolação, eram provedores de ar e luz, onde se desenvolviam muitas atividades ao ar livre com privacidade. Dada a importância desse compartimento, eram providos de altares para o deus Herkios - deus do "courtyard" (pátio interno descoberto). Os ambientes para o norte eram para as atividades noturnas e os ambientes para o sul eram para as atividades à luz do dia. Materiais utilizados: barro, tijolos e pedras. Possuíam pisos pavimentados com mosaicos, mármores ou tijolos, principalmente nas salas de jantar. Nos demais ambientes, o piso poderia ser de terra batida.

Exemplo:

2.6.1.1. Casa de Muitas Cores - data de 450 a 500 anos da nossa era, reflete bem a estrutura interna da família grega, especialmente na identificação e localização do "Oecus". 
Tabela 8- Casa de Muitas Cores Olynthos -Grécia

\begin{tabular}{l|c|c}
\hline AMBIENTE & FUNÇÃO/USO & ÁREA $\left(\mathrm{m}^{2}\right)$ \\
\hline Andorn & Estar(masculino)/ Receber & $2,50 \times 4,00=10,00$ \\
\hline Oecus & Estar(feminino)/ Receber & $4,80 \times 5,00=24,00$ \\
\hline Depósito & Estocagem & $4,50 \times 4,50=20,25$ \\
\hline Cozinha & Prep. de Alimentos & $2,50 \times 2,00=5,00$ \\
\hline 2 Dormitórios & Repouso/ & $4,50 \times 4,50=20,25$ \\
\hline Cisterna & Reservatório. de àgua & $3,50 \times 5,50=19,25$ \\
\hline
\end{tabular}

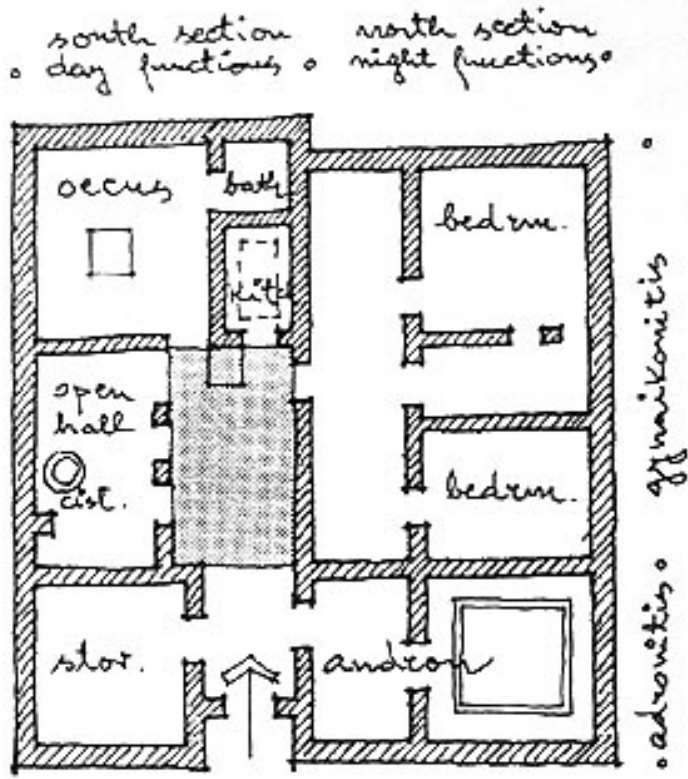

Fig. I 22- Casa de Muitas Cores Olynthos Grécia Fonte: SCHOENAUER

, com indicações do autor

O interior da casa só pode ser visto de dentro, refletindo as atividades do dia a dia e a estrutura familiar dos moradores.

O Oecus, quarto feminino ao lado da cozinha e do banheiro, o modo de vida influenciando na distribuição da habitação. A figura feminina é segregada.

A Cisterna também em espaço aberto e pode ser vista como um diferencial.

\subsubsection{ROMA}

O Império Romano nos deixa exemplares residenciais, principalmente nos trabalhos de Vitruvius e nas obras da cidade de Pompéia.

A civilização Romana foi construída sobre a cultura helênica. A casa romana "domus" era uma composição da casa etrusca com a helenística. O império Romano construiu muitas cidades e romanizou outras tantas. Com um padrão de eixos - cardo e decumanos fazendo ângulo de $90^{\circ}$ nas esquinas, 
onde ricos e pobres viviam lado a lado. A preferência era por casas orientais, de onde trouxeram a área pública separada da área privada e as alcovas alinhadas ao pátio descoberto; porém seus conceitos buscavam obras monumentais. As casas seguiam o padrão oriental em áreas urbanas altamente adensadas. O "Atrium" era das casas etruscas, o pátio das casas orientais, e o "Peristyle" - das casas helenísticas, com visão introspectiva e preferência por fachadas planas, interrompidas apenas pelas lojas. Normalmente com um pavimento e interior suntuosos, com pisos de mosaicos e mármores, paredes com afrescos e tetos com enfeites de ouro. Além do altar, os dois pátios eram adornados com fontes, estátuas, jarros, etc. A porta de entrada era sagrada e protegida por quatro deuses. As casas possuíam caixas de drenagem de a.p. impluvium abaixo do piso.

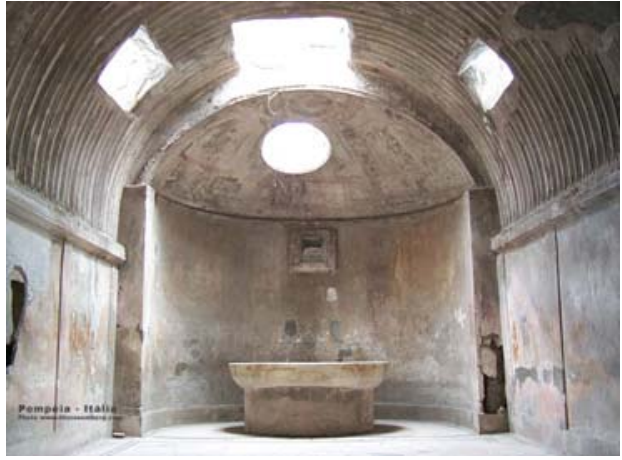

Fig. I 23- Tetos decorados Pompéia Fonte :autor

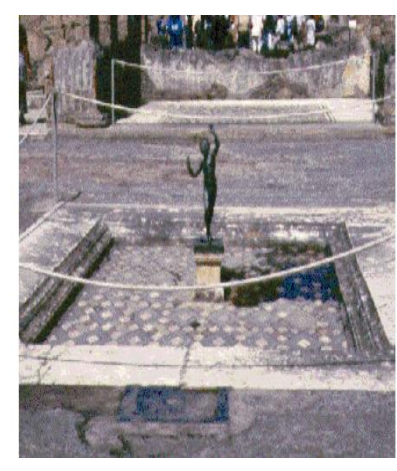

Fig. I 24- Piso em mosaico Pompéia Fonte: autor

Glossário dos ambientes das casas romanas:

- Hospítia - dormitório para hospedes

-Ergastuae - dormitório para escravos

- Alae - sala de visitas ou conversação

-Compluvium - beiral com calha em volta do átrio 
- Atrio - serve pra funções públicas

- Peristyle - era usado pela família - maior

- Culina - cozinha com despesas

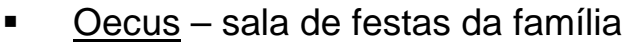

- $\quad$ Triclinium - sala de Jantar com divãs

- Tablinum -principal sala de recepção da casa

- Cubiculum - dormitórios em volta do peristyle

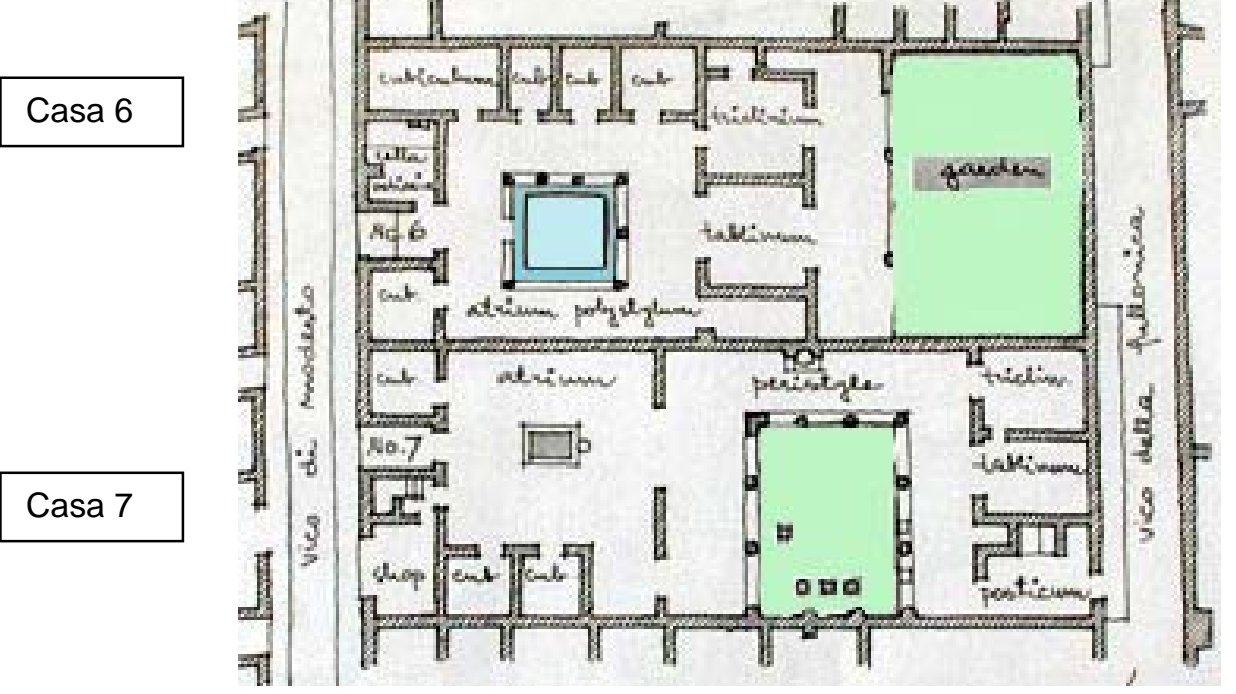

Fig. I 25-Casa 6 e 7 Pompéia

Fonte: SCHOENAUER

Com indicações do autor

área Casa $6=400,00 \mathrm{~m}^{2}$, sendo $100,00 \mathrm{~m} 2$ de jardim e $28,00 \mathrm{~m}^{2}$

no pátio descoberto - "Perisytlle".

área Casa $7=370,00 \mathrm{~m}^{2}$,

sendo $50,00 \mathrm{~m} 2$ de

Pátio descoberto 


\subsection{Tradicional Casa Islâmica}

A casa se desenvolve ao redor de um pátio descoberto da mesma forma que as citadas anteriormente. O espaço aberto no interior da casa wast- eddar, - possui uma fonte ou coletor de águas no seu centro; é rodeado por ambientes cuja cobertura é sustentada por pilares e arcos, os iwans, cada um deles com uma porta central. Estes cômodos são longos e estreitos, com aproximadamente $2,50 \mathrm{~m}$. As casas maiores são divididas em dois espaços: o salamlik (público) e o harem (setor privado, familiar da casa).

Iwan - a função desse ambiente é a recepção de pessoas: para negócios, pessoas da família ou mesmo amigos. No exemplo acima temos cinco Iwan's, dependendo da localização dos mesmos podem ser para público ou para a família. As áreas variam de 6 a $25 \mathrm{~m} 2$. As influências européias levaram a uma modernização do $4^{\circ}$ iwan, utilizado para recepções ou negócios.

Neste exemplo, a Dirka (Vestíbulo) faz as vezes das "Spirit Walls", vistas nas casas da antiguidade.

Exemplo: Cidade de Tunis - Século X ou XI

Casa Dar Sfar considerada idêntica às residências de Al Fusta no Egito.

Área construída total $=162,50 \mathrm{~m}^{2}$

Tabela 9- Casa de Dar Sfar

\begin{tabular}{l|c|l}
\hline AMBIENTE & FUNÇÃO/ USO & ÁREAS $\left(\mathrm{M}^{2}\right)$ \\
\hline DIRKA & Acesso & $2,50 \times 4,00=10,00$ \\
\hline RECEPÇÃO & Receber/ fazer negócios & $5,50 \times 4,80=26,40$ \\
\hline $1^{\circ}$ PÁTIO & Iluminação/Ventilação & $7,00 \times 7,00=49,00$ \\
\hline $1^{\circ}$ IWAN & Atividades Diárias & $2,50 \times 11,00=27,50$ \\
\hline $2^{\circ}$ IWAN & Serviços & $2,50 \times 11,50=28,75$ \\
\hline COZINHA & Preparo de Alimentos & $2,50 \times 2,00=5,00$ \\
\hline $3^{\circ}$ PATIO & Lazer homem / mulher & $3,00 \times 3,00=9,00$ \\
\hline
\end{tabular}




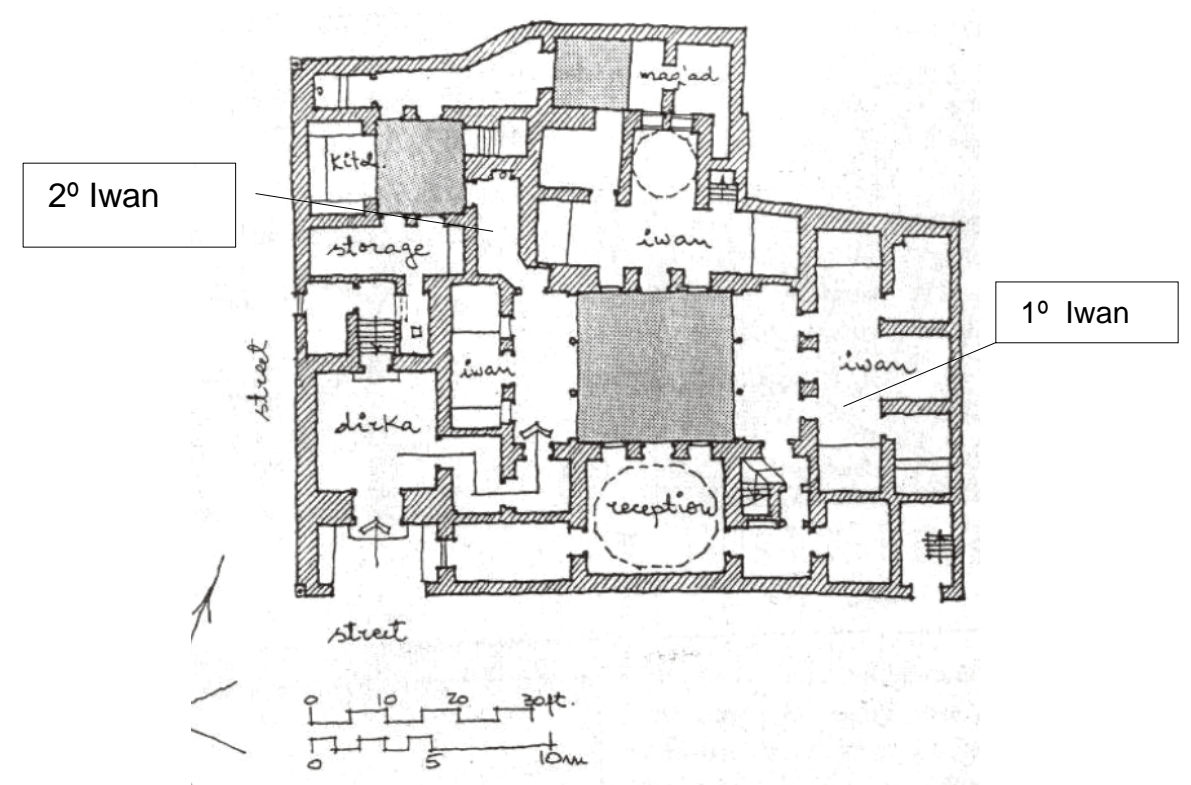

Fig. I 26-Planta Casa Dar Sfar Fonte SCHOENAUER Com anotações do autor

\subsection{A Tradicional Casa Hindu}

As cidades eram circundadas por muros, sendo subdivididas em MOHALLAS. As Mohallas são células como bairros onde se concentravam habitantes de igual origem, religião ou casta. Ricos e pobres moravam lado a lado diferenciando apenas o tamanho e o luxo das casas. A privacidade era preservada ao máximo, com a utilização de halls, paredes e outros aparatos para inibir transeuntes e visitantes. Os pisos superiores abrigavam os quartos e outros espaços destinados a tarefas variadas, com janelas e varandas. A cozinha era próxima do santuário da casa.

As casas tinham o pátio interno como principal característica, pátio esse que variava de tamanho de uma cidade para outra. 


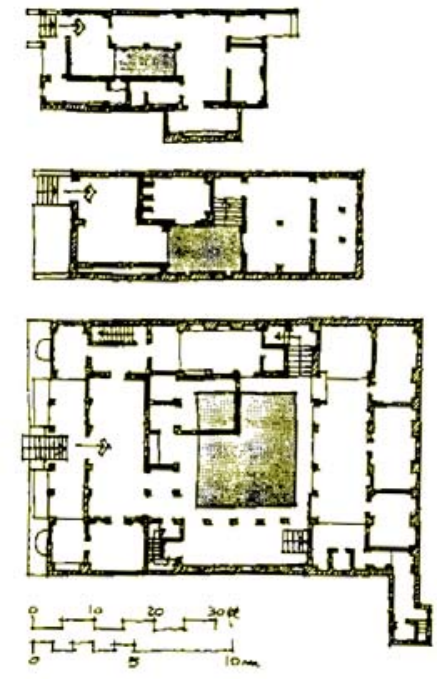

Fig. I 27 Jaisalmer

Fonte: SCHOENAUER

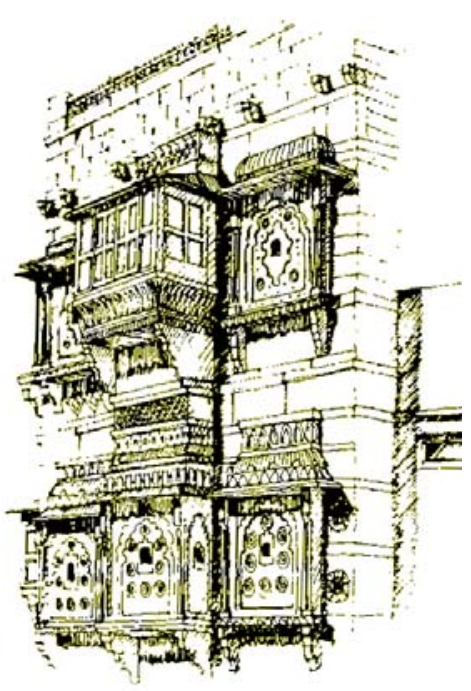

Fig I 28 -Exemplo de janelas de Jaisalmer Fonte::photos@bigshots. com.au

Os compartimentos não tinham uso específico, podendo ter um uso diurno e outro noturno. Outras cidades também apresentavam exemplos significativos, embora seguindo a mesma tipologia.

Desde os anos 1970, as autoridades hindus vêm promovendo um conceito de habitação social. Essa habitação, embora seja uma idéia atual, conserva vários conceitos das habitações tradicionais, inclusive com a presença do pátio interno. Trata-se de uma construção modular de quatro partes, cada parte com dois quartos de $24 \mathrm{~m}^{2}$ com uma varanda para cada família e que provê uma área de transição entre a rua e a casa e também uma área de serviço comunitária com dois sanitários e quatro lavanderias.

\subsection{A Tradicional Casa Urbana Chinesa}

$A$ área residencial das cidades é caracterizada pela monotonia, $A$ residência em si, consiste em quatro edifícios dispostos ao redor de um pátio, onde a ocupação e o uso se dão a partir do eixo norte - sul, de forma hierárquica. Existe um anteparo no hall de entrada que pode ser de tela ou 
parede, com o objetivo de inibir a visão direta para o interior da residência. As fachadas externas são monocromáticas. O uso tijolos e madeira pintados de vermelho é bastante comum.

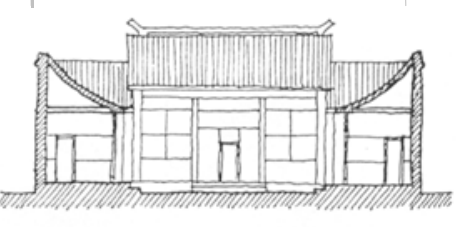

section

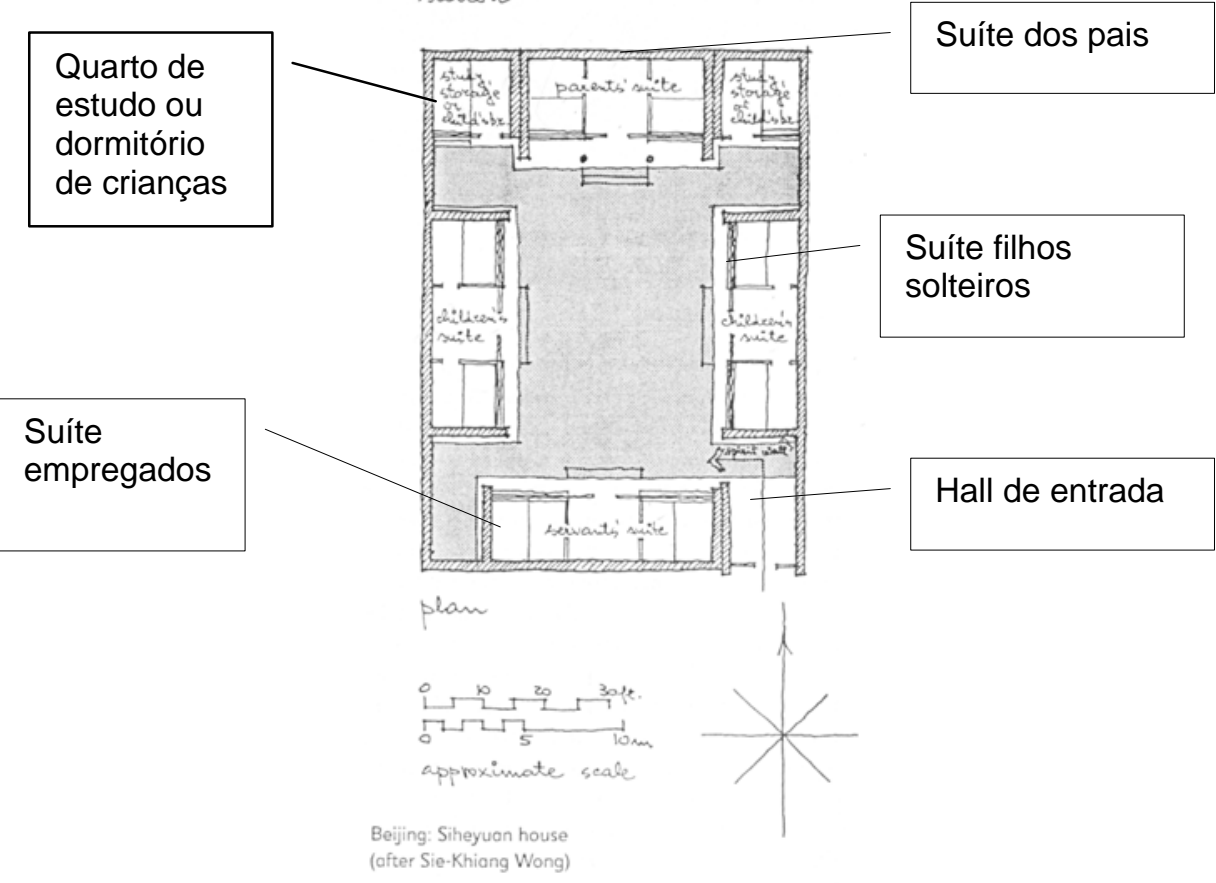

Fig I 29 -Planta Siheyuan Fonte SCHOENAUER

Tabela 10 Casa de Beijing Fonte: autor

\begin{tabular}{l|c|c}
\hline \multicolumn{1}{c|}{ AMBIENTE } & FUNÇÃO /USO & ÁREAS $\left(\mathrm{m}^{2}\right)$ \\
\hline SUITE PAIS & estar/dormir & 55,00 \\
\hline SUITE FIL.CASADOS & estar/dormir & 45,00 \\
\hline SUITE FIL. SOLTEIROS & estar/dormir & 45,00 \\
\hline ED. SUL & serviços & 50,00 \\
\hline ALAS NORTE & depósito/estudo & 20,00 \\
\hline PÁTIO & & 200,00 \\
\hline
\end{tabular}



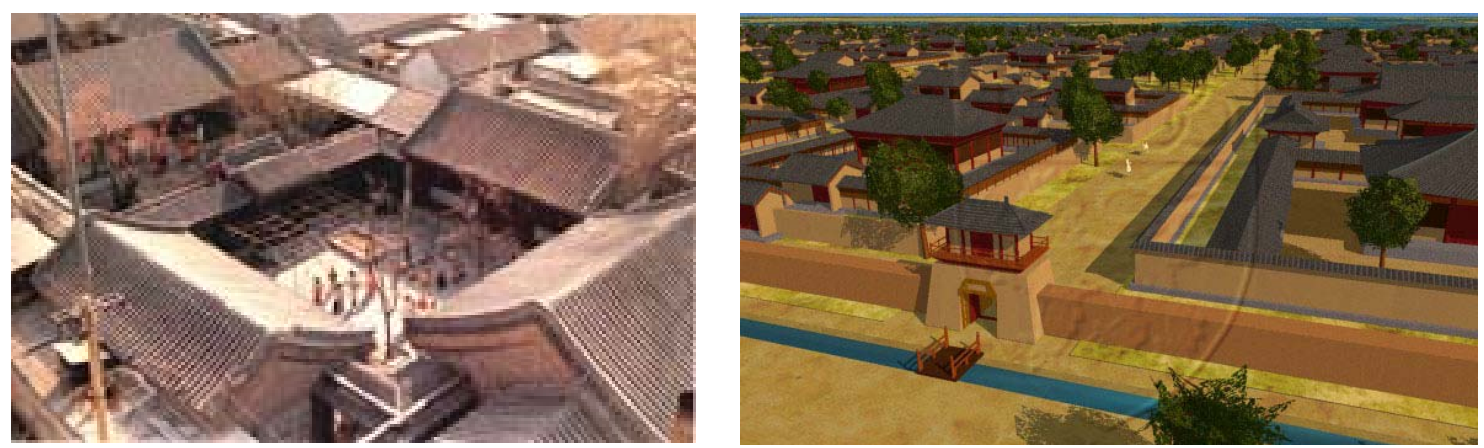

Fig. 30 e 31 Fotos Ilustrativas Casa Chinesa

Fonte:www.chinatoday.com.cn/English/ chinatours/beijinghutong.htm

Os edifícios de apartamentos surgiram a partir de 1949, com o objetivo de abrigar diversas famílias, podendo ser ou não funcionários de uma mesma empresa.

A política de governo foi preservar a harmonia e a integridade da velha Beijing e controlar a altura de construções novas. Os primeiros edifícios que surgiram foram construídos com áreas de 3,5 m2 por pessoa, com três ou quatro pavimentos, passando a ter oito andares e área de $20 \mathrm{~m} 2$ por pessoa em cidades novas e ricas como Shenzen.

\subsection{A Tradicional Casa Urbana Japonesa}

KYOTO serviu como residência da família imperial por mais de um milênio (794 - 1868). Posteriormente, a cidade foi dividida em dois blocos por uma avenida axial (chamada Suzaku), que vai desde a entrada do palácio até a parede da fortificação, criada na outra extremidade da cidade, ao sul. A cidade é subdividida em quadrados de aproximadamente $450 \mathrm{~m} 2$, cada quarteirão.

As fachadas das casas são voltadas para a rua, e sua tipologia é dividida em quatro classes sociais, durante o período feudal, que são: Samurais, Artesãos, Camponeses e Comerciantes. 
As habitações dos artesãos e camponeses ficam situadas em partes menos exclusivas da cidade, sendo construídas ao longo de um bloco de periferia, tendo a frente da residência para uma rua estreita, com um bloco aberto, de serviço central, às vezes utilizado para cultivo. Nessa época, a ostentação refletia falta de boas maneiras.

São casas-loja, com o objetivo de abrigar comerciantes e artesãos, construídas em madeira, quase sem mobília, apenas com amplos espaços para armários. A dimensão dos ambientes se dá a partir do tatame que é padronizado, e cada área segue a utilização de acordo com a cultura local. Por exemplo, o Zashiki (quarto mais formal) guarda os antepassados da família e o Tokonoma é adornado com um quadro e uma única flor em um vaso, utilizado para receber pessoas.

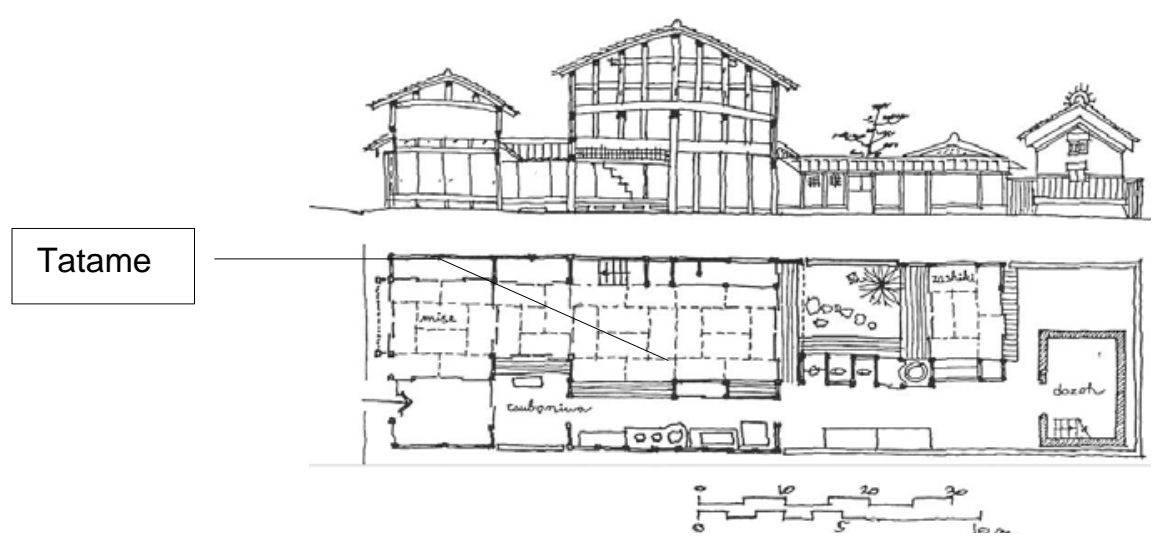

Fig.I 32 Planta e Corte Casa Machiya, Kyoto Fonte SCHOENAUER, com indicações do autor 


\section{As Casas Ocidentais da Era Moderna}

\subsection{Idade Média}

A parte 3 deste capítulo irá discorrer sobre como se comportou o dimensionamento nas casas a partir da Idade Média, as considerações sobre os aspectos políticos, econômicos e sociais serão brevemente listadas e tiveram como base o livro de SCHOUENAUER, 1981, como já citado.

A Idade Média foi estudada em duas fases, a Alta Idade Média e a Baixa Idade Média. A Alta Idade Média, a primeira fase, também chamada de Idade das Trevas, teve início com a desintegração do Império Romano e a invasão dos bárbaros.

Esses povos tinham a cultura bastante diversificada em relação à cultura romana, viviam da agropecuária de subsistência, da caça, de pilhagens e guerras, levando atraso às regiões invadidas. As principais áreas invadidas foram as cidades o que pressionou um grande êxodo para a zona rural. Em alguns lugares a população urbana desapareceu, por morte ou saiu em debandada.Mesmo na segunda fase da Idade Média, a partir do séc XIII, conhecida como Baixa Idade Média, quando a Europa estava no processo de reorganização, fenômenos como a Peste Negra (bubônica), contribuíram para desorganizar a vida urbana também.

O crescente ataque às cidades, logo após a queda do império romano fez com que a população evitasse este local para morar e ao mesmo tempo negasse as formas de moradia das casas gregas e romanas, sua forma intimista protagonizada pelos pátios internos as "spirit walls", a divisão das casas em 2 segmentos o feminino e masculino, as fachadas modestas e a mistura de classes sociais nos mesmos distritos das cidades, mesmo assim, a civilização urbana ocidental sofreu influencia das civilizações urbanas orientais.

Em uma época marcada por hostilidades a defesa era a principal preocupação, resultando na típica casa da Alta idade Média a casa torre. 
Outro tipo de casa da Alta Idade Média era a casa tipo espigão, construída em terrenos estreitos e profundos.

Os pátios internos continuaram a existir, principalmente na baixa Idade Média, porém com função diferente das casas da antiguidade, eram usados nas casas de comerciante para carga e descarga de mercadorias, enfim uma área de serviços e não mais área social "well of heaven" - poço do paraíso ${ }^{9}$ pois provia a casa de luz, ar e água de chuva.

\subsubsection{Alta Idade Média}

Sobre as ruínas romanas surgiram várias cidades européias. Os muros e portões destes eram uma defesa natural. No seu interior eram erguidas casas e igrejas. Anfiteatros de 25.000 lugares podiam ser transformados em cidades para 2.000 habitantes. Como as cidades de Toledo e Nimes.

Os burgos, fortificações de defesa contra os bárbaros, também foram núcleos de futuras cidades. Tinham grandes muros fortificados e um fosso ao seu redor. Uma torre central era erguida como ultimo abrigo em caso de ataque. Devido a essa proteção, artesãos, comerciantes e mercadores livres instalaram-se nos arredores dos burgos, formando uma extensão urbana e assim este também foi um ponto de partida para futuras cidades.

As cidades de Veneza e Dubrovnik foram fundadas por colonizadores que fugiram de suas cidades natais após ataque dos bárbaros e procuraram refúgio em locais quase inacessíveis, protegidos pela natureza.

Construída numa ilha para dificultar o acesso dos invasores, Dubrovnik, tinha uma proteção natural, transformou-se numa grande cidade portuária, ponto de encontro de várias culturas, tais como a árabe, cristã, eslava, latina, muçulmana.Por volta de 806 a cidade foi envolvida por muralhas de pedra o que garantiu a sua sobrevivência.

Uma das principais diferenças das casas européias das casas orientais é a relação com a privacidade já que nas casas orientais havia toda uma preocupação com a privacidade e religiosidade, daí a existência de um pátio

\footnotetext{
${ }^{9}$ Como era chamado na China o pátio interno, segundo SHOENAUER, 1981
} 
interno, esta preocupação não existente com as casas ocidentais moldadas a partir da idade média, com pouca influência da arquitetura romana, mas com influência da cultura e do cotidiano rural. Agora havia a preocupação de mostrar status e a existência de um pátio externo refletia essa condição.

Embora a tradição arquitetônica romana resistisse nas construções religiosas, as casas européias pós-romanas tinham uma concepção totalmente nova e muita dessas casas urbanas eram cópias das rurais, indicando relação entre atividades rurais e urbanas. Geralmente tinham dois pavimentos e um porão, não tinham corredores, no térreo havia um hall que servia de depósito ou como área de trabalho. Os quartos estavam no andar de cima.

\subsubsection{Habitações Tipo Torre}

Eram verdadeiras fortalezas, muito usadas na Itália e no noroeste da Europa. Essas torres, além de serem moradias, eram equipadas com vários aparatos de defesa como escadas e passadiços retráteis, portões, alçapões e varandas para que os moradores pudessem atirar flechas e pedras nos invasores.

Exemplo: Schwäbisch Hall : Turmhaus(Germânia)

Tabela 11- Turmhaus

Fonte Autor

Área Construída $=81,00 \mathrm{~m}^{2}$

\begin{tabular}{c|c|c}
\hline AMBIENTE & FUNÇÃO/ USO & $\operatorname{AREAS}\left(\mathrm{m}^{2}\right)$ \\
\hline SALA DA LAREIRA & Aquecer/ Estar & $4,00 \times 2,50=10,00$ \\
\hline DORMIT. (maior) & repouso & $4,50 \times 4,50=20,25$ \\
\hline DORMIT. ( menor) & repouso & $3,50 \times 3,50=12,25$ \\
\hline
\end{tabular}




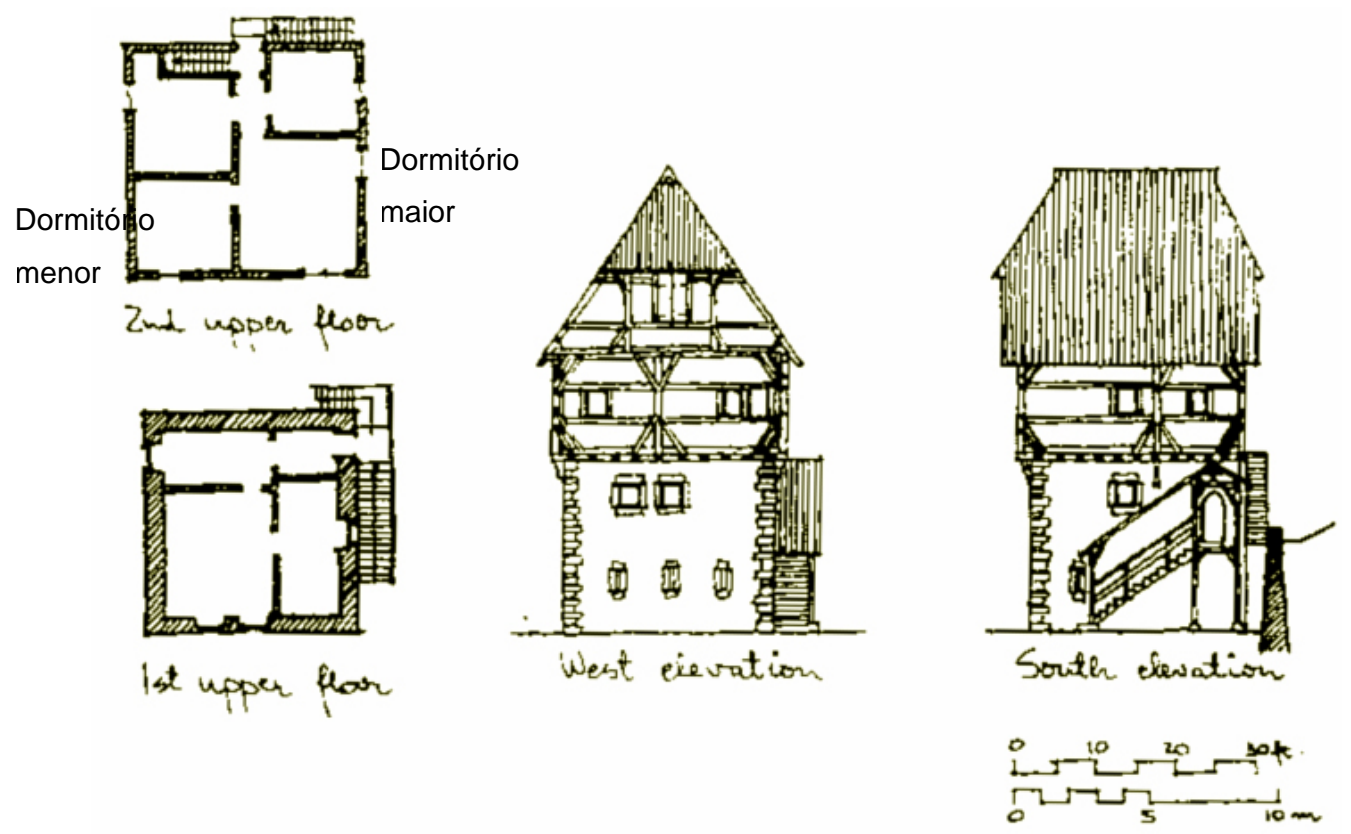

Fig. I 33 - Schwäbisch Hall (Germânia) TURMANHAUS Fonte SHOENAUER

A figura 33 mostra que nesta habitação não há corredores. No pavimento térreo o hall servia de depósito ou como área de trabalho. $\mathrm{O}$ primeiro pavimento possuía ambiente com lareira, não se identifica área de circulação, os ambientes são interligados entre si. Os dormitórios estavam no $3^{\circ}$ andar.

\subsubsection{Baixa Idade Média}

Com a melhoria da tecnologia da produção agrícola para a cultivo e o aproveitamento de madeiras, pântanos e terrenos baldios a agricultura deixou de ser apenas de subsistência. Esse desenvolvimento e aumento da população ocasionaram novamente à divisão do trabalho, o qual permitiu trocas, comércio e o desenvolvimento e o crescimento das cidades.

No mundo oriental e Grego-Romano, a urbanização estava invariavelmente acompanhada pelo trabalho escravo, mas a nova burguesia medieval, os comerciantes e artesãos, eram homens livres e privilegiados, estavam protegidos por leis, da prática do feudalismo. As muralhas eram fortificadas e outras instalações de defesa ainda eram necessárias. 
Muitas cidades da parte norte da Europa tinham um raio que raramente excedia $250 \mathrm{~m}$ e com área construída dentro de fortalezas fortificadas com menos de 20 hectares. A densidade da população das cidades estava em 48 pessoas por hectares, apesar da densidade dos setores residenciais poderem alcançar 500 a 740 pessoas por hectare. Exemplo: Nordlingen.

\subsubsection{Dubrovnik}

No final da Idade das Trevas Ragusa - hoje Dubrovnik, já era uma cidade significante e antes do fim do século XII os cidadãos desta cidade fizeram acordos comerciais com cidades outras cidades marítimas da Itália, proporcionando um crescimento natural do comércio pelo aumento da população dentro e fora da fortaleza.

Um pequeno subúrbio cresceu fora da fortaleza, predominantemente de colonização eslava. Esse subúrbio eslavo chamavase Dubrovnik. Placa era a principal rua de comércio de Dubrovnik.

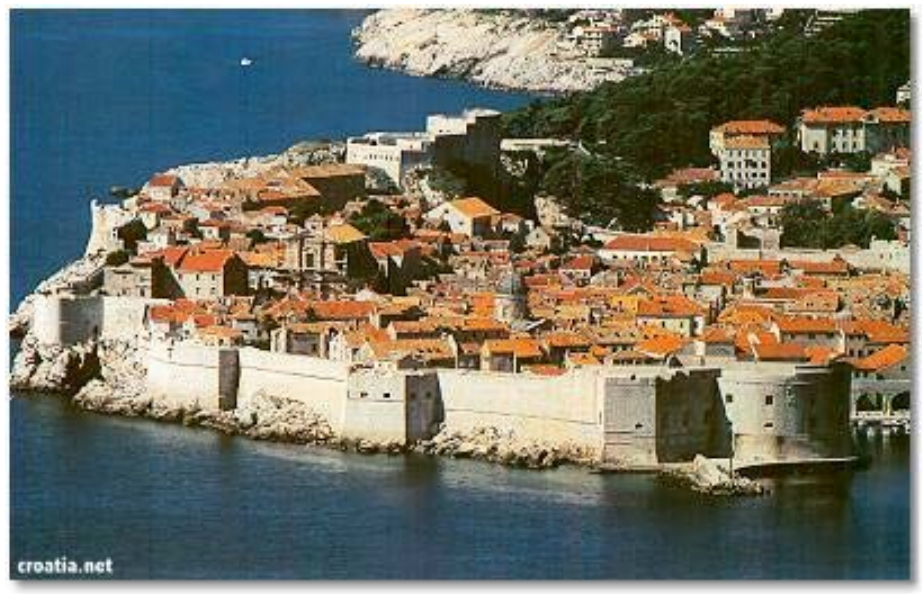

Fig.I 34 Imagem Ilustrativa da Muralha de Drubrovinik http://www.croatia.net/html/gallery6.html

A população de Dubrovnik estava dividida em três classes sociais: nobres, comunidade ou cidadão e camponeses. A maioria dos nobres de Dubrovnik era formada por comerciantes de Veneza.

Placa, a principal rua comercial,do lado norte. A largura típica das moradias urbanas era de $9 \mathrm{~m}$ e a altura delas era entre 10 e 12,8 m. As casas dos comerciantes possuíam 3 pavimentos , o primeiro era utilizado por loja 
continha recepção formal das pessoas que visitam a casa. O segundo andar era usado pela família, o qual tinha sala de jantar, sala de estar e quartos de dormir. Enquanto que o sótão continha a cozinha e o cômodo de armazenamento e às vezes o quarto dos criados.

Exemplo: Típica casa na área da Placa

Tabela 12 - Típica Casa na Rua Placa

Fonte: autor

\begin{tabular}{l|c|c}
\hline \multicolumn{1}{c|}{ AMBIENTE } & FUNÇÃO/ USO & ÁREA (m2) \\
\hline PISO TÉRREO: & Comercio & 125,00 (total) \\
\hline HALL & Acesso & 20,00 \\
\hline RECEPÇÃO & Recepcionar & 38,00 \\
\hline QUARTO 1 & Repouso & 20,00 \\
\hline QUARTO 2 & Repouso & 18,00 \\
\hline COZINHA & Preparo de alimentos & 12,00 \\
\hline
\end{tabular}

Área total construída $=375 \mathrm{~m}^{2}$

Área destinada a Habitação $=355 \mathrm{~m}^{2}$

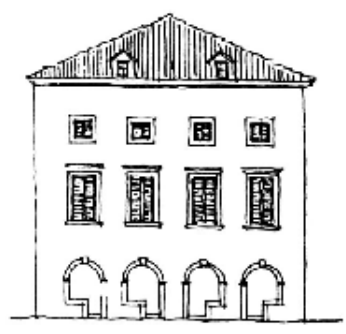

elevação frontal

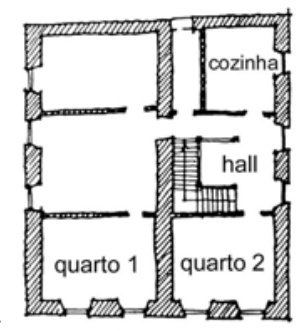

$2^{\circ}$ andar

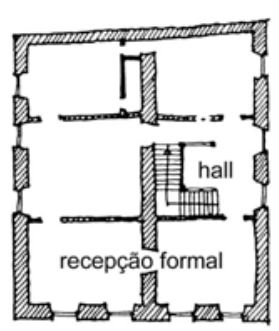

$1^{\circ}$ andar

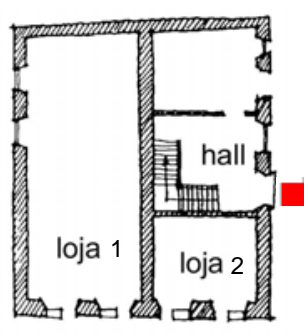

térreo

Fig. 35 -Elevação e plantas da Casa típica da Placa Fonte: SCHOENAUER

A cidade fortaleza, Dubrovnik, hoje com 16 hectares possui 5000 pessoas em 2000 moradias. O layout físico inclui muitas quadras, uma largura de rua principal (a mesma da Placa na época medieval) e rede de ruas e pista de pedestres.Dubrovnik tem aspecto único, mas é tipicamente mediterrânea, revela muita influência do oriente onde os comerciantes medievais buscavam riquezas. 


\subsubsection{Final da Idade Média}

Grande número de burgueses adquire sua casa própria, em função das regras e privilégios que beneficiavam somente o proprietário. A extensão da frente da casa indicava a riqueza do proprietário, principalmente quando se tratava de uma loja numa rua comercial, quanto maior, melhor os negócios, portanto eram nestes setores que os comerciantes escolhiam para morar. A atividade comercial era parte integrante da casa (atelier para um artista; loja para comerciantes). Os espaços residenciais e comerciais eram perfeitamente, compatíveis.

\subsection{Renascimento}

Entre 10001350 e durante a Idade Média, um número de cidades aumentou incrivelmente e calcula-se que no curso de quatro séculos (10001400) foram fundadas 2.500 cidades só na Alemanha. A população destas cidades também se multiplicou significativamente, chegavam a dobrar freqüentemente em menos que um século. O crescimento de população era especialmente impressionante na França, Inglaterra, e Itália.

A epidemia de Peste Negra que golpeou a Europa durante o século XIV teve um efeito catastrófico. Bloqueou o crescimento de cidades, matou quase a metade da população total, atingindo toda e qualquer família, sendo ela rural ou urbana, alfabetizada ou não, rica ou pobre. A utilização da pólvora (muito conhecida na Ásia) foi desenvolvida como um explosivo efetivo, e assim as paredes das fortalezas das cidades medievais ficaram inúteis.

O progresso e o custo de um novo sistema de fortalezas consumiu muitas riquezas. Com a exceção de cidades na Inglaterra que estavam relativamente protegidas de ataque por sua posição privilegiada em uma ilha, a maioria das cidades no continente europeu suportaria o fardo financeiro adicional de erguer novas linhas de defesa. Além disso, a expansão física destas cidades ficou mais difícil. Assim, muitas cidades superpovoadas, só poderiam ter expansão interna; conseqüentemente os edifícios cresceram para cima. 
A influência clássica nas artes e na literatura, durante o século XV acompanhada por um incremento intelectual, deu inicio a ciência da era moderna. Este movimento passou a ser conhecido como o Renascimento, este fato também pode ser visto no humanismo e urbanismo. Foram construídas poucas cidades novas durante o Renascimento exceto como fortificações ou residências magníficas, mas a atividade de edificar começou na reconstrução e extensão de cidades existentes.

Os princípios de planejamento urbano da época preconizavam, avenidas largas e ruas diretas com um focal no horizonte. Ruas medievais que estreitas e curvas agora recebem intervenção com a implantação de largas avenidas com traçado geométrico cruzando a antiga trama, mantendo sempre um visual ampliado e focado em algum ponto de interesse. A escala humana das cidades medievais desapareceu gradualmente e também foi trocada prontamente para uma escala monumental e impressionante.

Atração estética e ordem não eram somente responsáveis pela transformação, os veículos com rodas que entraram em uso geral durante o século XVI passaram a exigir padrões novos, especialmente para as ruas principais. Considerações militares estavam contribuindo para os fatores de mudança em dimensões de rua e padrões, não mencionando o desejo através de regras despóticas para eliminar qualquer lembrança física da colocação urbana medieval que refletiu o individualismo fortuito desfrutado pelos burgueses. Por exemplo, a sobrevivência de ruas estreitas medievais em Paris proveu a justificação para Napoleão III arrasar quarteirões inteiros e prover bulevares largos. Foram previstas avenidas como símbolos importantes na cidade pós-medieval. Nenhum outro exemplo ilustra melhor estes planos do que a disputa de Versalhes e Karlsruhe.

Ambiciosos planos de cortar avenidas por cidades medievais nem sempre tiveram sucesso. Por exemplo, o plano de Christopher Wren para Londres; que era trazer ordem na cidade depois do Grande Fogo de 1670 nunca foi realizado; foi anulado por hábitos mercantis tenazes e direitos de propriedade. Onde Wren falhou, o Barão Haussmann obteve sucesso em Paris. Ele construiu o Bulevar São Michel "rasgando o coração do "Quartier Latin" que 
tinha sido uma entidade quase autônoma desde a Idade Média"10 uma área cheia de vida e para qual não havia nenhuma justificação.

No período pós-medieval a vida na corte tinha uma influência crescente na cidade e em seus habitantes, especialmente da classe média. As pessoas não pensavam no palácio em termos de um único edifício com suas funções elegantes, mas sim no estilo palaciano de vida que era invejado por todos. A etiqueta da corte influenciou os modos de cidadãos ordinários, e a palavra "cortejar", ilustra até que ponto o comportamento elegante tinha penetrado no comportamento das pessoas.

Nas cidades a casa e o lugar de trabalho ficaram separados durante o Renascimento, uma separação que até então não teve nenhum precedente na evolução de alojamento urbano. Posteriormente a casa seria um lugar para entreter, comer, dormir, mas não onde a pessoa trabalhava para apoiar a família. Esta separação afetou moradores urbanos mais ricos primeiro, mas, como veremos atingiu todos os habitantes.

A tendência de separar a casa do lugar de negócio pareceu sem importância no princípio, mas teve repercussões profundas em desenvolvimento de cidade durante séculos subseqüentes. Eventualmente, mulheres perderam toque com negócios no mundo externo, e homens, em troca, perderam o toque com negócios domésticos. A unidade social básica, a família, sofreu uma mudança profunda. Na realidade, a separação de 'vida de casa' e 'vida de negócio' também afetou a vida além das paredes da casa.

As várias classes de cidadãos começaram a tomar conta de si mesmos. As famílias de classe-média se instalaram atrás das fachadas anônimas das casas de cidade que na coletividade, ou no seu conjunto, se assemelham a palácios reais.

"Se a pessoa não gozasse de condições financeiras para sustentar a vida familiar em um palácio, a próxima melhor coisa era viver em um setor de um conjunto de casas que pareciam um palácio. O individualismo medieval expresso nas casas pitorescas dos burgueses se tornou uma coisa do passado. Foi substituído entusiasmo por coletivismo 
impessoal que empregou a ordem clássica impressionante como uma colocação elegante para um tipo novo de vida familiar. ${ }^{11}$

Tanto na França como na Inglaterra a burguesia era uma classe ambiciosa descontentada com o absolutismo e em conflito constante. Foi este grupo que trouxe a vitória do livre comércio e terminou feudalismo.

\subsubsection{As Praças Residenciais}

No começo do século XVIII, o rei Henri IV de França planejou a mais nova Praça Residencial na França: o Place Royale. Este empreendimento foi um esforço para juntar às casas da aristocracia ao rei, e recriar o grande esplendor da corte no coração de Paris. Eram trinta e oito edifícios de três andares que se uniam ao nível do térreo por uma arcada. Henry IV previu esta Praça com o propósito de colocá-la como "a vida cosmopolita contrária a cidade confinada". O tratamento arquitetônico das fachadas destes edifícios era uniforme; elas foram construídas de alvenaria de tijolos vermelhos e pedras claras, e as janelas e portas foram organizadas simetricamente.

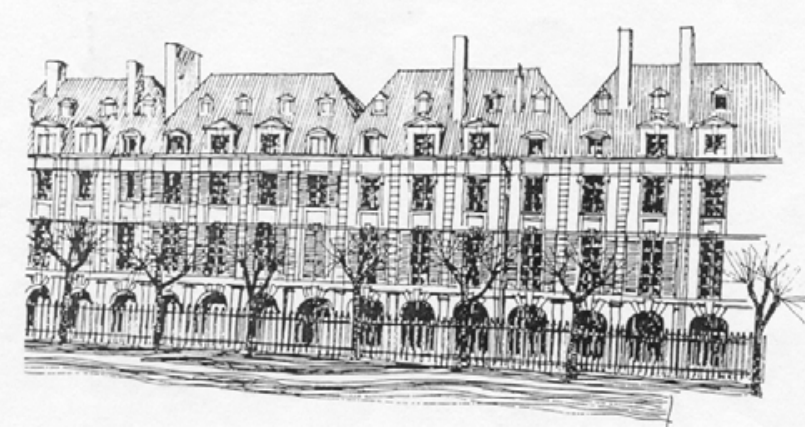

Fig. I 36-Fachada Place de Vosges (Place Royale) Fonte: SCHOENAUER

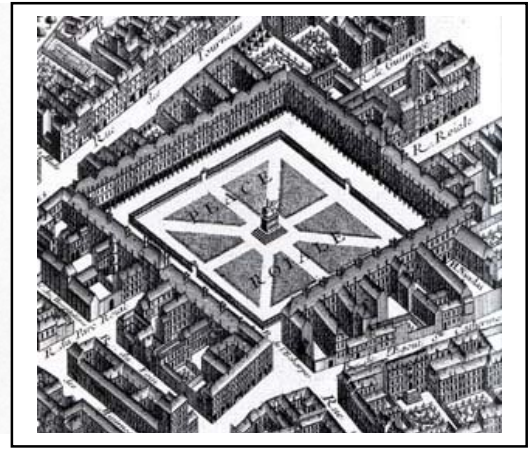

Fig. I 37 Desenho ilustrativo da Place Royale

Fonte:http://marais.evous.fr/marai s/patrimoine/place-des-

vosges/place-des-vosges.htm

${ }^{11}$ SCHOENAUER, 1981 pág. 269 (tradução do autor) 


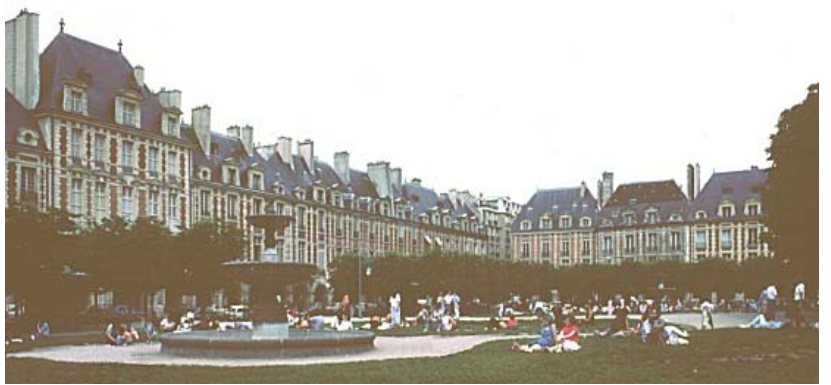

Fig.l 38 Foto llustrativa da Place Royale http://www.bluffton.edu/ sullivanm/vosges/vosges.html

O conceito de uma Praça Residencial era novo, logo foi adotado por outros aristocratas que assim se tornaram os primeiros especuladores imobiliários. O Duque de Vendôme, um nobre falido mas com algumas terras, burlou a legislação da época, com uma proposição sedutora de criar na terra dele um lugar monumental com uma estátua que glorificaria a monarquia. "Mansart", assim, as fachadas do Place Vendôme foram construídas. Antes desta construção os lotes atrás da fachada foram vendidos, dando inicio ao "Real State", ou seja, temos aqui o inicio da especulação imobiliária, segundo SCHOENAUER (1981).

O desenvolvimento de uma Praça Residencial em Londres foi introduzido pelo Conde de Bedford. Aproximadamente 2,8 hectares foram designados para um empreendimento de uma Praça Residencial, um grande retângulo central era cercado em dois de seus lados por arcadas de edifícios residenciais com uma fachada clássica que escondiam atrás de si casas de variavam na largura e profundidade. A Igreja permaneceu em um dos eixos axiais enquanto os jardins da casa de "Bedford" ficavam no outro eixo. Posteriormente esta praça central foi chamada de "Convent Garden", este empreendimento foi um sucesso instantâneo. 


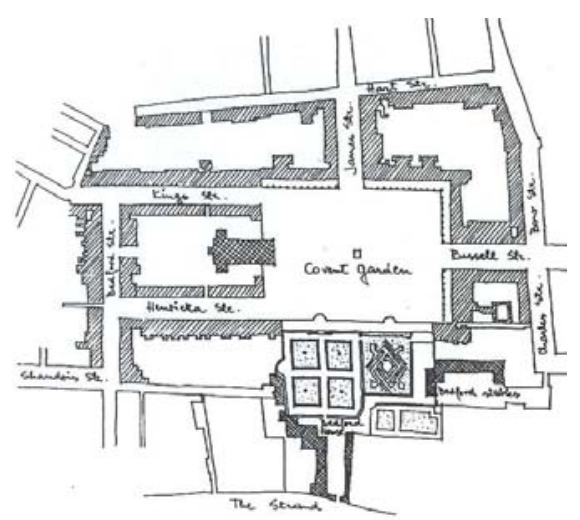

Fig. I 39-Planta Convent Garden Londres 1680-1685 Fonte : SHOENAUER

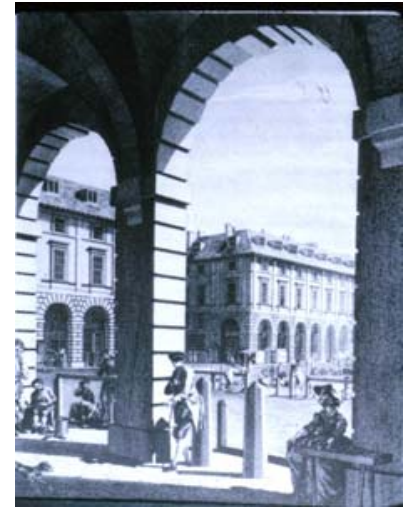

Fig.I 40 Imagem Ilustrativa Convent Garden http://intranet.arc.miami.edu/riohn/Spring20 00/New\%20slides/Jones\%20and\%20Wren \%20slides/Convent\%20Garden.jpg $05 / 05 / 2006$

Várias outras praças com esta tipologia foram sendo construídas em Londres no séc. XVII ${ }^{12}$ e logo se espalharam por outras cidades. $\mathrm{O}$ exemplo ocorrido na cidade de Bath foi de muito sucesso.Cidade conhecida por suas características terapêuticas desde a época romana, revive após estada da Rainha Anne (Queen Anne). Aproveitando esta "publicidade" o arquiteto John Wood the Elder, adquiriu uma carta de arrendamento por 99 anos de uma grande propriedade em Bath e empreendeu uma obra inédita, no local que resultou em inúmeras quadras residenciais, sendo a $1^{\text {a }}$ a Queen's Square (vide fig.41 e 42).

\subsubsection{Casa na Queen's Square. (1727)}

Tabela 13 -Casa Dupla Quen's Square Fonte autor

\begin{tabular}{l|c|c}
\hline \multicolumn{1}{c|}{ AMBIENTE } & FUNÇÃO/ USO & AREAS $\left(\mathrm{m}^{2}\right)$ \\
\hline HALL & Acesso/ principal & 9,00 \\
\hline SALA DE JANTAR & Refeições & 25,00 \\
\hline SALA DE ESTAR & Receber IVisitas & 25,00 \\
\hline DORMITÓRIOS C/ LAR. & Dormir/descanso & $5,00 \times 5,00=25,00$ \\
\hline JARDIM & Lazer & 65,00 \\
\hline S. DE VISITAS (2) & Estar da família & 35,00 \\
\hline QUARTO DE VERTIR & Troca de roupa & 12,00 \\
\hline
\end{tabular}

\footnotetext{
${ }^{12}$ SCHOENAUER, 1981, passim .
} 


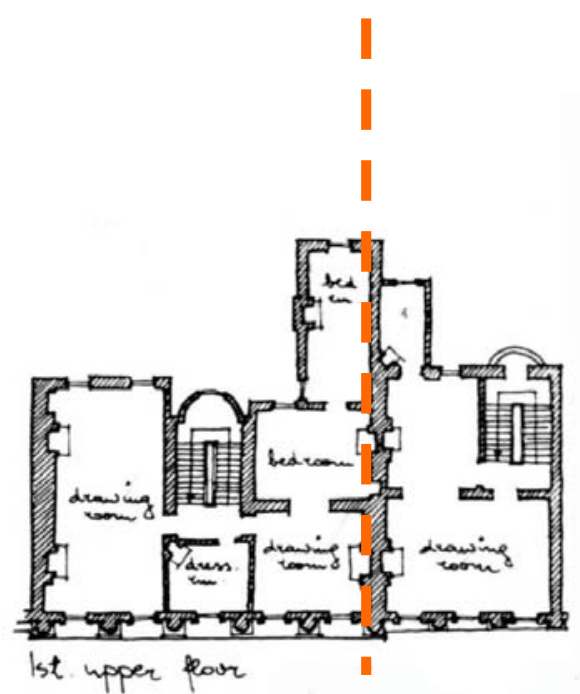

Área total construida da Casa dupla $=380,00 \mathrm{~m}^{2}$

Fig.l 41- Pav. Superior Casa Dupla - Queen's Square Bath - Inglaterra

Fonte: SCHOENAUER

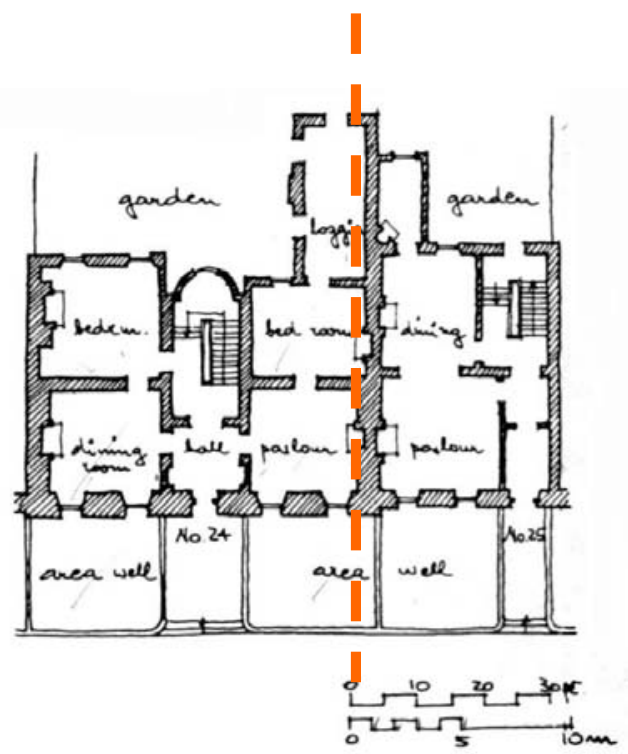

Área total construida da Casa simples $=220,20 \mathrm{~m}^{2}$

Fig.l 42 -Pav. Térreo Casa Dupla na Queen's Square Bath - Inglaterra Fonte: SCHOENAUER

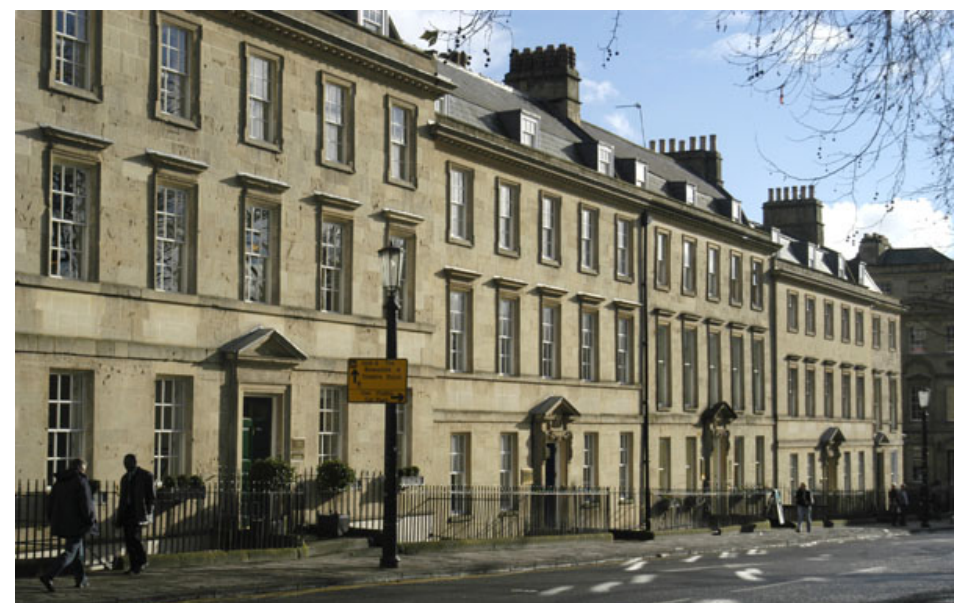

Fig.I 43 Imagem Ilustrativa de Quen's Square East Side http://www.bathmuseum.co.uk/buildings.htm

John Wood the Elder, continuou empreendendo e realizou a King's Circus (1754) na Gay Street (ou rua Gay), aonde desenhou fachadas côncavas ao invés de convexas, para casas de 3 pavimentos, lembrando as fachadas dos anfiteatros romanos. Apesar dos moradores destes grandes complexos, de vista 
e implantação magníficas não serem da realeza, estas edificações transmitiam um ar de nobreza.

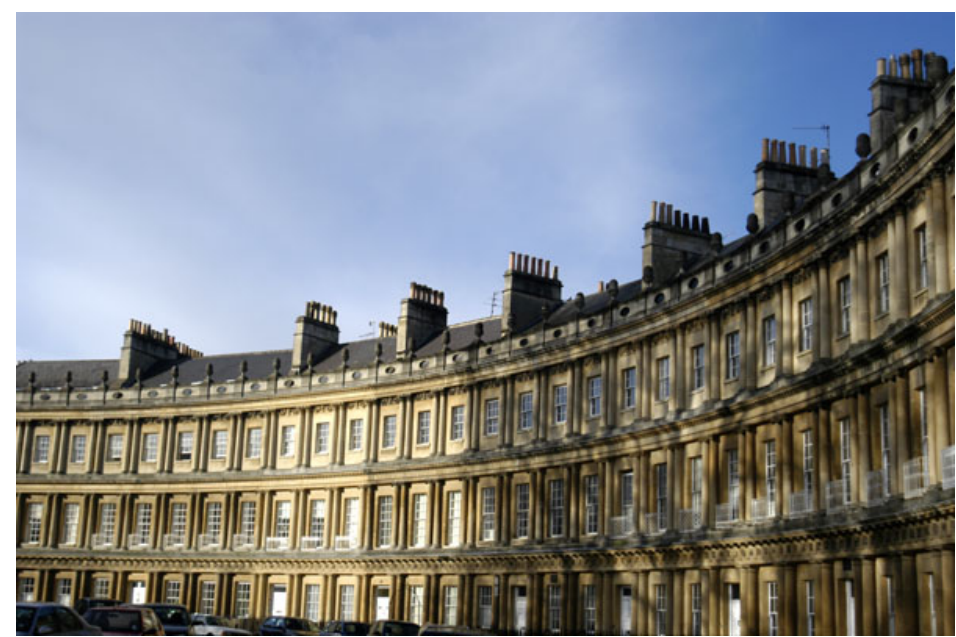

Fig.I 44 Imagem Ilustrativa King's Circus http://www.bathmuseum.co.uk/images/gallery/Roofline\%20of\%20Kin g\%27s\%20Circus.jpg 05/05/2006

Das várias Praças Residenciais em Londres durante o século XVIII, Bedford Square em Bloomsbury ilustra provavelmente uma das melhores Praças Residenciais. O desenho da Praça é atribuído ao arquiteto Thomas Leverton, mas sua execução foi deixada a vários construtores. Foram arrendados os quatro lados da Praça a construtores especulativos que ergueram filas quase uniformes de casas de cidade ao longo dos lotes. A terra foi arrendada durante noventa e nove anos, como em Bath, depois da expiração desta data a terra e os edifícios nela reverteram à propriedade de Bedford.

\subsection{A Casa de Cidade}

No ocidente a casa "privada" evoluiu como resultado da separação de vida privada e pública. A habitação se tornou separada de qualquer meio visível de renda. Assim, um tipo de edifício genérico entrou em existência para a classe média: a casa de cidade.

A casa de cidade teve suas raízes em habitações urbanas fixas medievais, porém, o comércio, parte intrínseca das casas das cidades medievais, foi eliminado. 
Gradualmente, com o desenvolvimento de Praças Residenciais e a construção em larga escala por especuladores imobiliários, transformou a casa de cidade em um produto, que na ocasião não foi considerada "real arquitetura". Não obstante, era um tipo de edifício refinado, e investidores prestaram atenção considerável a seu aspecto estético, por nenhuma outra razão que o de atrair o público. Os construtores de casas de cidade tinham que vender ou arrendar suas obras, eles tentaram satisfazer as idéias prevalecentes de beleza na época, tiveram que ter cuidado com o desenho e construir com materiais que eram aceitáveis pelo público.

A fachada de uma casa típica de Londres consistia em duas janelas salientes e uma porta de entrada. Entre a divisa com a rua e a edificação existia um poço com uma estreita escada de serviço.O pequeno desnível entre a calçada e o hall de entrada era vencido por uma ponte e alguns degraus. A seção dianteira da casa estava ocupada por uma sala de estar e o hall ; atrás , enquanto olhava-se o quintal, tínhamos a sala de jantar. Ambos espaços eram acessíveis pelo corredor com uma escadaria que era a comunicação vertical de toda a habitação. A sala de estar funcionava como hall de entrada, em alguns casos, para visitas de parentes ou amigos íntimos da família. A posição sala de jantar ao nível do térreo era determinada por conveniência, todos os quartos de serviço como também a cozinha ficavam situada no andar de baixo.

O segundo nível de uma casa de cidade típica londrina, era conhecido como o andar nobre,com um pé direito mais generoso, continha usualmente dois quartos além do corredor; um quarto largo usado predominantemente por homens ocupando a frente inteira da casa, enquanto na parte traseira um quarto estreito onde fumar não era permitido, designado para uso por mulheres. O terceiro nível continha o quarto dos donos da casa, como também os quartos das crianças, enquanto o sótão, iluminado por trapeiras, continha os quartos dos criados. Para a parte traseira da propriedade ficavam os estábulos e instalações relacionadas.

Detalhes exteriores e interiores como também as proporções de casas de cidade eram clássicas, mas a ornamentação era freqüentemente encontrada na fachada dianteira, limitando a entrada principal, como exemplificado nas casas de cidade na Praça de Bedford. 


\subsubsection{Cadogan Square $n^{\circ} 68$ arquiteto Norman Shaw}

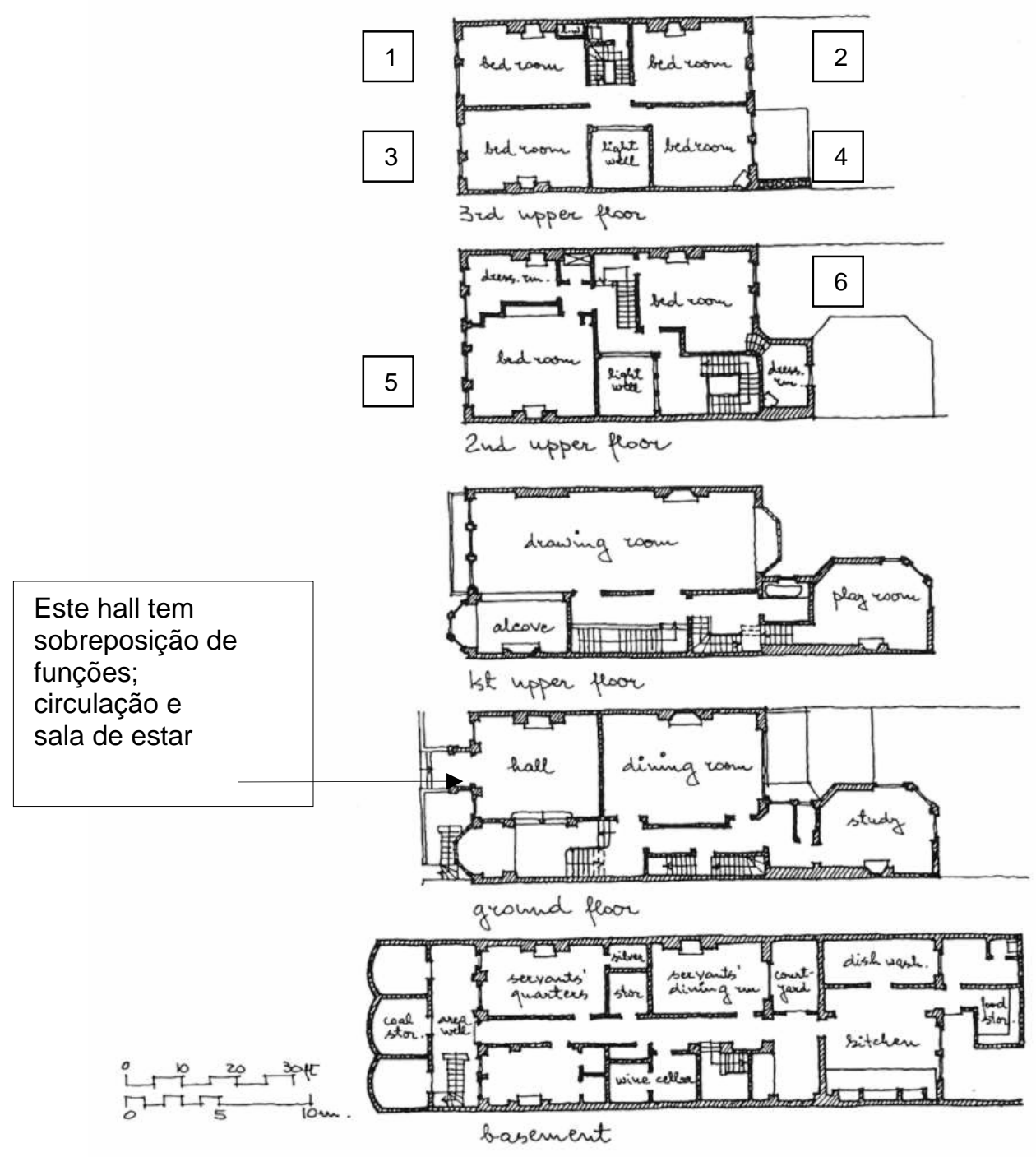

Área total construída $=962,40 \mathrm{~m}^{2}$

Fig. I 45 -Cadogan Square Londres

Fonte: SCHOENAUER 
Tabela - 14 Cadogan Square $n^{\circ} 68$ Fonte: autor

\begin{tabular}{|c|c|c|c|}
\hline & AMBIENTE & USO/ FUNÇÕES & ÁREA $\left(\mathrm{m}^{2}\right)$ \\
\hline \multirow[t]{3}{*}{$3^{\circ} \mathrm{Pavimento}$} & DORMITÓRIO 1E 3 & Repouso/dormir & $6.50 \times 4,50=29,25$ \\
\hline & DORMITÓRIO 2 & Repouso/dormir & $6,00 \times 4,50=27,00$ \\
\hline & DORMITÓRIO 4 & Repouso/dormir & $5,00 \times 4,50=22,50$ \\
\hline \multirow[t]{3}{*}{$2^{\circ}$ Pavimento } & QUARTO DE VESTIR 2 & Guarda e Troca de roupas & $4.40 \times 2.60=11,44$ \\
\hline & DORMITÓRIO 5 & Repouso/dormir & $6,50 \times 6,50=42,25$ \\
\hline & DORMITÓRIO 6 & Repouso/dormir & Irreg. $=29,25$ \\
\hline \multirow[t]{5}{*}{ 1Pavimento } & "DRAWING ROOM" & Estar/lazer/ receber íntimo & $15,00 \times 5,50=82,50$ \\
\hline & ALCOVA (C/ JANELA) & Decanso & Irreg. $=16,00$ \\
\hline & SALA DE JOGOS & Lazer & $6,00 \times 4,50=27,00$ \\
\hline & HALL ESCADARIA & Átrio / vestíbulo /circulação & $10,00 \times 3,00=30,00$ \\
\hline & BANHEIRO & higiene & $2,50 \times 2,00=5,00$ \\
\hline \multirow{4}{*}{$\begin{array}{l}\text { Pavimento } \\
\text { Térreo }\end{array}$} & HALL & Acesso/ estar formal & $6,00 \times 6,00=36,00$ \\
\hline & SALA DE JANTAR & Refeições & $8,50 \times 6,00=51,00$ \\
\hline & ESTÚDIO & Trabalho / estudo & $6,00 \times 4,50=27,00$ \\
\hline & CIRCULAÇÃO ESCADA & Interligação pavimentos & $14,00 \times 3,00=42,00$ \\
\hline \multirow[t]{3}{*}{ Subsolo } & COZINHA & Preparo de alimentos & $6,00 \times 6,00=36,00$ \\
\hline & DORMIT. EMP. & Repouso empregados & $6,50 \times 4,00=24,00$ \\
\hline & SALA DE JANTAR EMP. & Refeições & $6,00 \times 4,00=24,00$ \\
\hline
\end{tabular}

O subsolo ainda apresenta, deposito de lixo, adega, prataria, depósito, despensa e área para lavagem de louça entre outros não identificados.

Pode-se verificar o uso nos dias de hoje destes imóveis, com as dimensões atuais através de planta retirada de site de imóveis na Inglaterra, verificando a utilização deste espaço e como foi subdividido em apartamentos menores, porém, ainda na faixa de 170,00 a 180,00m² de área. 


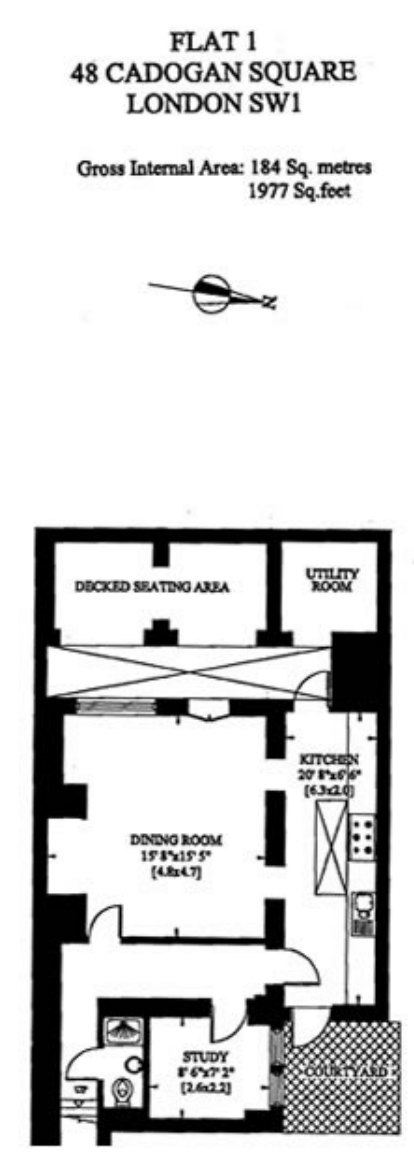

LOWER GROUND FLOOR

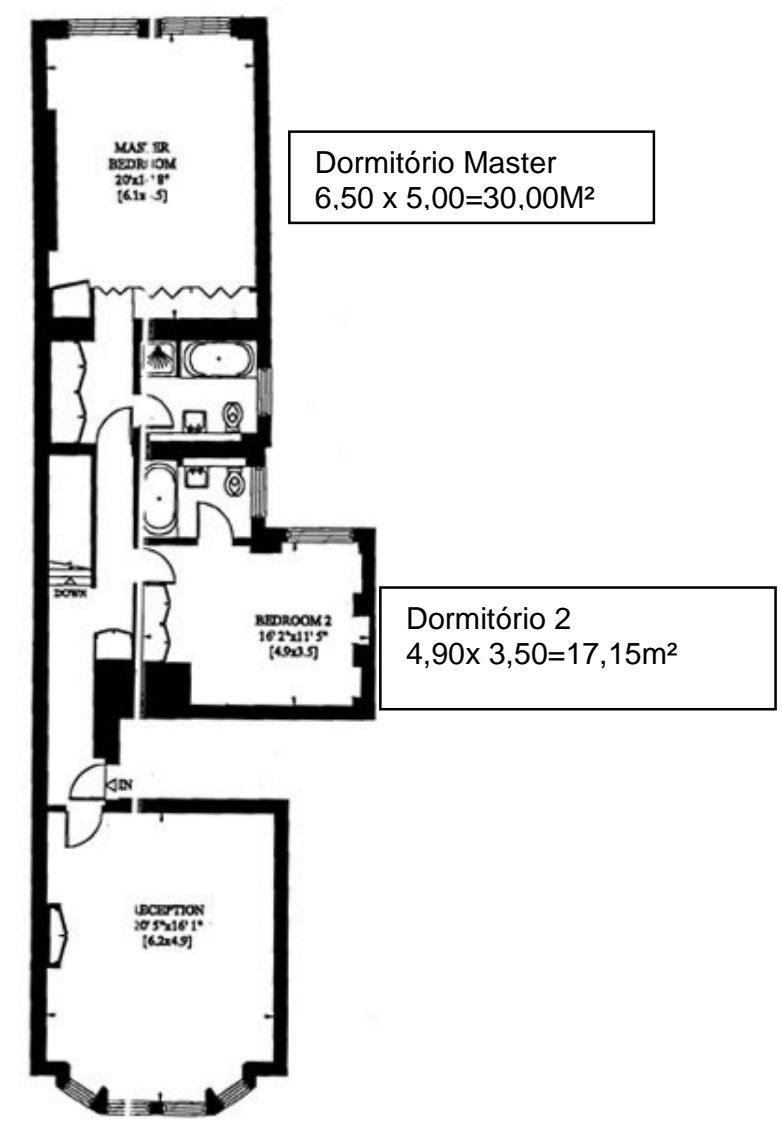

GROUND FLOOR

Área construída $=184 \mathrm{~m}^{2}$

Fig.I 46 Imagem Ilustrativa- Cadogan Square, Londres,

Fonte:http://www.brahmestates.com/apartments/5_13cadogansquare.html\#

A separação da família de negócios empresariais cotidianos, também provocou uma mudança em casa segundo sua organização. Responsabilidades domésticas que tinham sido compartilhadas pelo marido e esposa, agora se tornavam a responsabilidade exclusiva da mulher e, de certo modo, um trabalho especializado. O serviço doméstico tinha sido uma atividade necessária desde os primórdios, mas agora é encarada como um ritual.

No mundo novo (EUA) a casa de cidade ficou popular durante os séculos XVIII e XIX, provavelmente Filadélfia foi a primeira cidade americana a 
adotar este conceito inglês de viver urbano. Até mesmo hoje, estas habitações ainda são consideradas como as mais charmosas feitas na Filadélfia.

A construção de casas de cidade em Nova York começou mais tarde, no final do século XVIII e início do século XIX. Na maioria dos casos o projeto das casas londrinas era usado como modelo, mas com uma diferença significante no plano americano, não havia acomodações no porão ou no forro. A entrada de serviço era próxima ao nível de acesso e um desnível conduzia à entrada dianteira para a sala de estar.A figura ilustra casa de cidade típica de Nova York. É interessante notar que acima da sala de estar (parlor) temos um dormitório principal voltado para a rua e outro dormitório voltado para o quintal com acesso direto para o banheiro. Este dormitório principal também tem a função de dupla de estar e dormir. Entre os dormitórios temos os closets que funcionam como uma barreira acústica além da guarda de roupas.

O subsolo, como nas casas londrinas também é usado para serviços, cozinha, despensa e dependências de empregados.

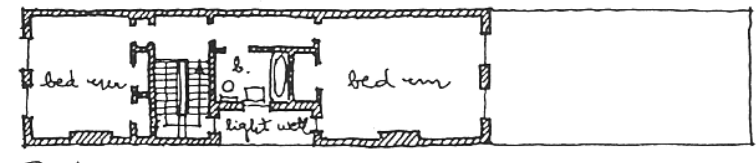

Znd upper floon

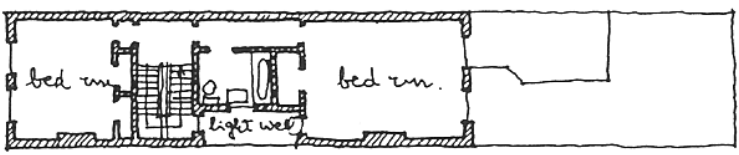

lst upper floor

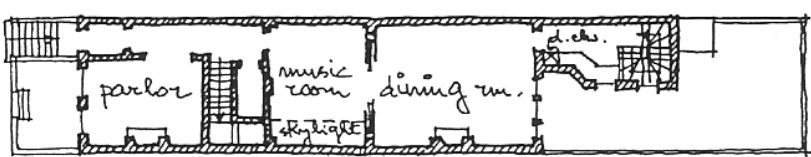
ground floor

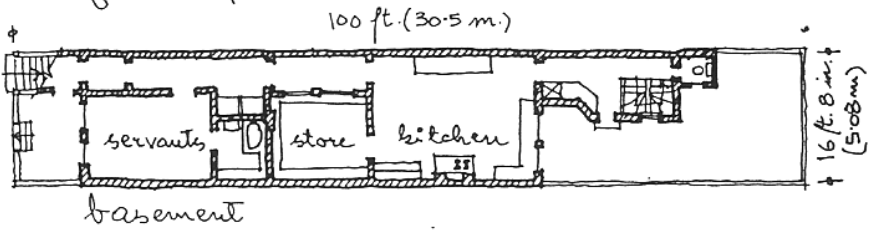

Fig. I 47 Exemplo de Casa em Cidade em Nova York Fonte : SCHOENAUER 


\subsection{Séc. XX - Industrialismo}

A revolução industrial é um dos mais importantes períodos da era moderna, talvez o termo evolução, ao invés de revolução seria mais apropriado segundo o SCHOENAUER ${ }^{13}$, no entanto as modificações foram tão profundas que o termo revolução também é apropriado.Tendo ocorrido em tempos diferentes em cada país.A Inglaterra foi a primeira a experimentar as suas conseqüências.

As residências também fizeram parte do conjunto de edificações próximas as indústrias. As casas dos empregados nesta fase inicial da Revolução Industrial eram parecidas com as casas rurais, apesar da mudança significativa que foi sair do campo e ir para a cidade, mantiveram um jardim ou quintal aonde poderiam plantar para consumo próprio.

"As cidades cresceram em tamanho, tiveram um aumento de população impressionante, na mesma proporção os problemas sociais, que também derivaram do modo de morar antiquado, se multiplicaram"14 .

A industrialização e a urbanização produziram "favelas" super lotadas.Em 1842 Edwin Chadwick, envia uma pesquisa sobre "as condições de saneamento em que vivia a população operária,", este documento trouxe uma alteração na legislação inglesa que concedia mais espaços abertos em torno das construções visando melhor ventilação. Deste tipo de iniciativas surgiu o modelo de casas de aluguel para famílias, construções que foram um extraordinário avanço para a época.

\footnotetext{
13 SCHOENAUER 1981 pág. 289.-tradução do autor
}

${ }^{14}$ Ibid. 6, pág. 290 
3.4.1. Tenement Buildings - "Modelo de Casa para Famílias" - 1780
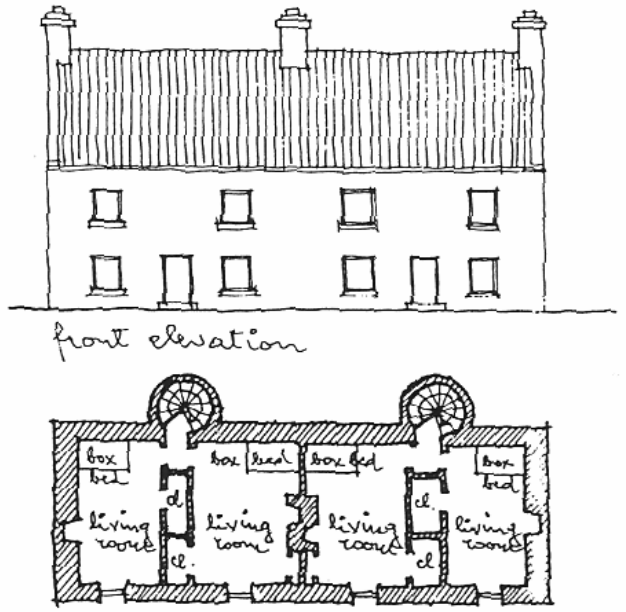

upper floor

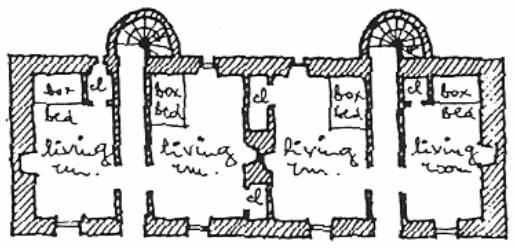

gromed floon

Fig. I 48 Weaver's Tenements Fonte SCHOENAUER
Eram moradias com ambientes determinados como cozinha, copa, sala, dormitórios e banheiros.

Este exemplo é de casa de aluguel do tipo back to back, ou seja, com uma face iluminante.

No final do século XIX e início do século XX, parte considerável de áreas residenciais em cidades industriais como Liverpool e Birmingham usavam as casas geminadas em 3 faces como residência de trabalhadores. Eram também chamadas de casas cavernas.

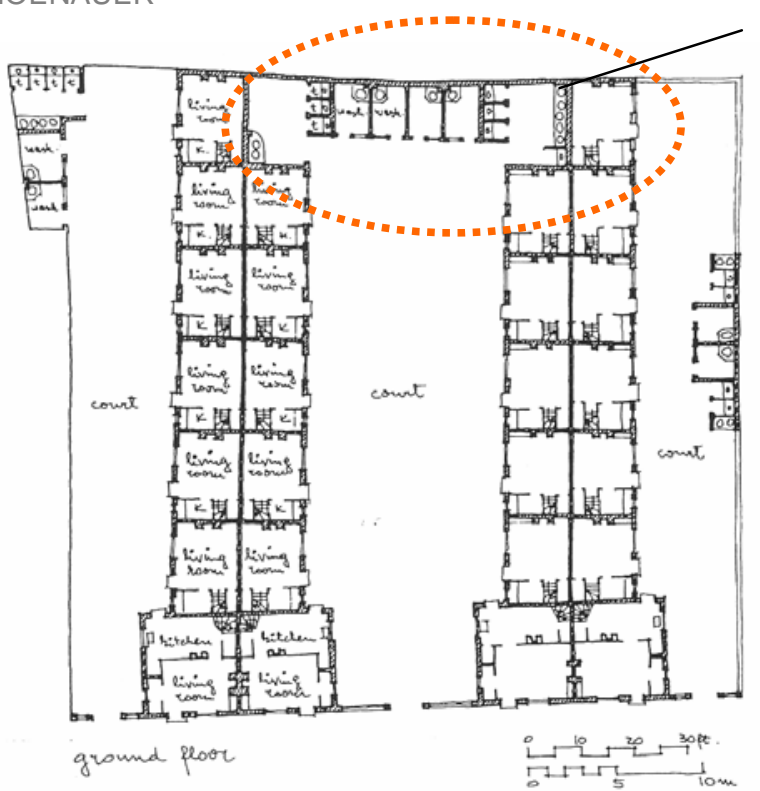

Fig I 49 Birmingham: Courts Fonte : SCHOENAUER 
Tabela - 15 Birmingham: Courts Fonte autor

\begin{tabular}{l|c|c|c}
\hline & AMBIENTES & USO/ FUNÇÃO & ÁREA $\left(\mathrm{m}^{2}\right)$ \\
\hline \multirow{3}{*}{$\begin{array}{l}\text { PAVIMENTO } \\
\text { TÉRREO }\end{array}$} & SALAS & Estar e fazer refeições & $3,30 \times 3,50=11,55$ \\
\cline { 2 - 4 } & COZINHAS & Cozinhar & $2,00 \times 1,30=2,60$ \\
\cline { 2 - 4 } & CIRCULAÇÃO & Escadaria e Hall & $1,20 \times 1,20=1,44$ \\
\hline
\end{tabular}

\subsection{2. "Bylaws Model's “ Nottingham-1879}

Durante a $2^{\mathrm{a}}$ metade do século XIX as autoridades começaram a impor regras para a construção residencial, visando uma melhoria das condições de habiitabilidade, surgiram em algumas cidades inglesas e nova-iorquinas as casas pela lei. As construções se deram em grande escala destas casas, as ruas não arborizadas, não inspiravam desenvolvimento urbano, contrastando com as ofertas do mercado em cidades.

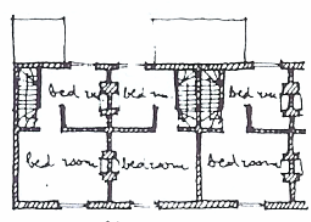

upper ilor

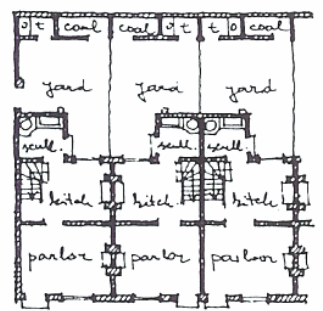

ground Hoor

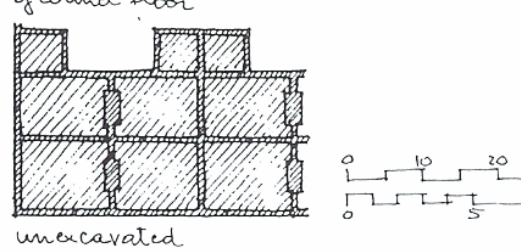

Tabela - 16 Bylaw Housing (Casas pela lei) Nottingham 1879 Fonte Autor

\begin{tabular}{c|c|c|c}
\hline & AMBIENTE & USO/ FUNÇÃO & ÁREA $\left(\mathrm{M}^{2}\right)$ \\
\hline \multirow{4}{*}{ Térreo } & SALA DE ESTAR & Acesso/Circulação/Estar & $3.60 \times 2.80=10,08$ \\
\cline { 2 - 4 } & COZINHA & Cozinhar/ Refeições & 8,74 \\
\cline { 2 - 4 } & CIRCULAÇÃO/VERTICAL & escada & $2 ., 22$ \\
\cline { 2 - 4 } & BACIA SANITÁRIA & banheiro & $0,70 \times 1,00=0,70$ \\
\cline { 2 - 4 } & DEP. CARVÃO & estocagem & $0,70 \times 2,00=1,40$ \\
\hline \multirow{3}{*}{ Superior } & DORMITÓRIO / FUNDOS & Repouso/dormir & 5,25 \\
\cline { 2 - 4 } & DOMITORIO /FRENTE & Repouso/dormir & $2,70 \times 3,45=9,30$ \\
\cline { 2 - 4 } & CIRCULAÇÃO & escada & 2,72 \\
\hline
\end{tabular}

Área total construída $=54,00 \mathrm{~m}^{2}$

Área do Lote $3,80 \times 11,60=44,08,2$

Fig. I 50 Bylaw Housing, Nottingham (1879).

Fonte: SCHOENAUER 


\subsubsection{As Vilas Suburbanas}

O transporte melhorado (ônibus, carruagens e estradas de ferro), possibilitou a banqueiros, comerciantes e advogados, que deixassem as vilas e fossem para os subúrbios, em propriedades particulares e com moradia mais adequada para a família. As dimensões eram generosas, lembrando o tamanho dos dormitórios das casas de "Cadogan Square", porém, os serviços(cozinha e banheiros) ainda são de menor importância apesar do tamanho da casa.

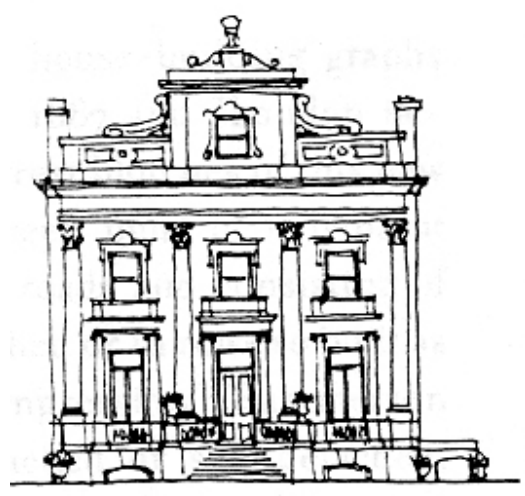

brant devation

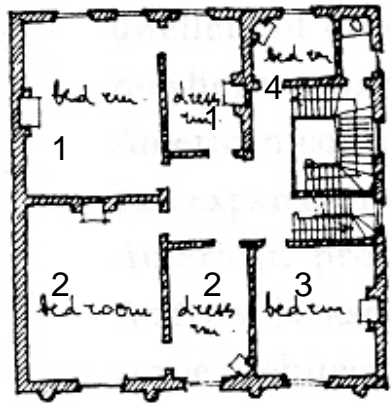

upper Hoor

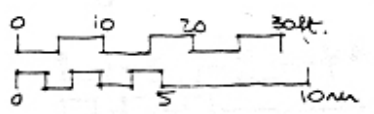

A suburban villa (after C. J. Richardson)
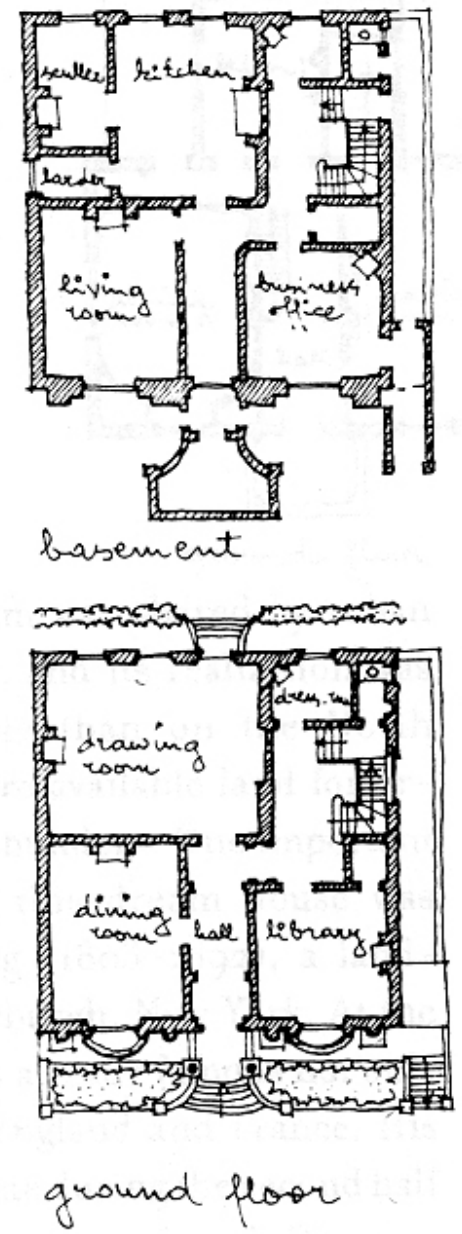

Fig. I 51 - Exemplo de Vila Suburbana - Inglaterra

Fonte: SCHOENAUER 
Tabela 17 - Vila Suburbana Londres -

Fonte: autor

Área total construída $=490,00 \mathrm{~m}^{2}$

\begin{tabular}{|c|c|c|c|}
\hline & AMBIENTE & USO/ FUNÇÕES & ÁREA $\left(\mathrm{m}^{2}\right)$ \\
\hline \multirow{8}{*}{$\begin{array}{l}\text { Pavimento } \\
\text { Superior } \\
163,00 m^{2}\end{array}$} & Dormitório 1 & Repouso/dormir & $4.50 \times 5.80=26,10$ \\
\hline & Quarto de Vestir 1 & $\begin{array}{l}\text { Guarda de roupas } \\
\text { Trocar de roupas }\end{array}$ & $2.50 \times 4.40=11,00$ \\
\hline & Dormitório 2 & Repouso/dormir & $5.90 \times 4.60=27,14$ \\
\hline & Quarto de Vestir 2 & $\begin{array}{l}\text { Guarda de roupas } \\
\text { Trocar de roupas }\end{array}$ & $4.40 \times 2.60=11,44$ \\
\hline & Dormitório 3 & Repouso/dormir & $4.35 \times 4,00=17,40$ \\
\hline & Dormitório 4 & Repouso/dormir & $2.80 \times 2.10=5.98$ \\
\hline & $\begin{array}{l}\text { Circulação } \\
\text { Horizontal e Vertical }\end{array}$ & $\begin{array}{c}\text { União entre ambientes e } \\
\text { pavimentos }\end{array}$ & $\sim 28,45$ \\
\hline & Banheiro & Higiêne & $1.00 \times 2.00=2,00$ \\
\hline \multirow{7}{*}{$\begin{array}{l}\text { Pavimento } \\
\text { Térreo } \\
163,00 \mathrm{~m}^{2}\end{array}$} & Quarto de Vestir & $\begin{array}{l}\text { Guarda de roupas } \\
\text { Trocar de roupas }\end{array}$ & $2.70 \times 2.00=5,40$ \\
\hline & Sala de Visitas & Receber/público & $5.80 \times 7.25=42,05$ \\
\hline & Sala de Jantar & Fazer Refeições & $5.90 \times 4.45=26,25$ \\
\hline & Hall & $\begin{array}{l}\text { Átrio /vestibulo } \\
\text { circulação }\end{array}$ & $4.25 \times 2.11=9,00$ \\
\hline & Biblioteca & Estudo/receber íntimo & $4.50 \times 4.30=19,35$ \\
\hline & $\begin{array}{l}\text { Circulação } \\
\text { Horizontal e Vertical }\end{array}$ & & $\sim 22,00$ \\
\hline & Banheiro & Higiene & $1.00 \times 2.00=2,00$ \\
\hline \multirow{6}{*}{$\begin{array}{l}\text { Subsolo } \\
163,00 \mathrm{~m}^{2}\end{array}$} & Despensa & Guarda Alimentos & $1.40 \times 2.40=3,36$ \\
\hline & Cozinha & Cozinhar & $5.90 \times 4.75=28,03$ \\
\hline & Sala de Estar & Estar íntimo & $4.55 \times 5.64=25,71$ \\
\hline & Escritório & Trabalhar & $4.50 \times 4.40=19,80$ \\
\hline & Circulação & $\begin{array}{l}\text { União entre ambientes e } \\
\text { pavimentos }\end{array}$ & $\sim 29,00$ \\
\hline & Dormitório & Repouso/dormir & $2.70 \times 2.00=5,40$ \\
\hline
\end{tabular}

\subsubsection{Apartamentos em Paris}

Influenciados pelo luxo e divisão dos hotéis parisienses, os prédios de apartamentos buscam nestas edificações muitas similaridades, e através do modo de vida da época o programa de necessidades é visualizado através dos ambientes existentes; como o pequeno salão para receber familiares e pessoas íntimas, o grande salão para recepções mais formais.O dormitório da dona da casa, aonde só era permitida a entrada de pessoas muito íntimas, era o ambiente considerado "lar do lar" ${ }^{15}$, pois era aonde ela passava a maior parte do

${ }^{15}$ Ibid.Página- 318, tradução do autor 
tempo. Apesar de interligados os ambientes tinham acesso por um corredor. A divisão em zonas social, de serviços e íntima fica clara nestas plantas.

Durante a $2^{\mathrm{a}}$ metade do século XIX, modernidades nas instalações hidráulicas (sanitárias e cozinha) fizeram com que as pessoas começassem a abandonar a tradição de "morar de aluguel".

Os edifícios mistos não poderiam perder a pompa, mesmo visando a classe média, como exemplo da rua Theodore de Banville esquina rua Gustave Flaubert, tinham área para lojas no térreo e um elevador no meio da escadaria. Existia no pavimento tipo uma escada de serviço que levava ao ático onde ficavam os dormitórios de serviço para todos os apartamentos. Os dormitórios maiores e salas de jantar eram voltados para a rua, os dormitórios menores, cozinhas e banhos voltados ao pátio interno descoberto. Este exemplo retrata a divisão adotada nos apartamentos , ou seja:

- Zona de estar - pública

- Zona de serviços

- Zona Íntima - dormitórios, sala da senhora e etc...

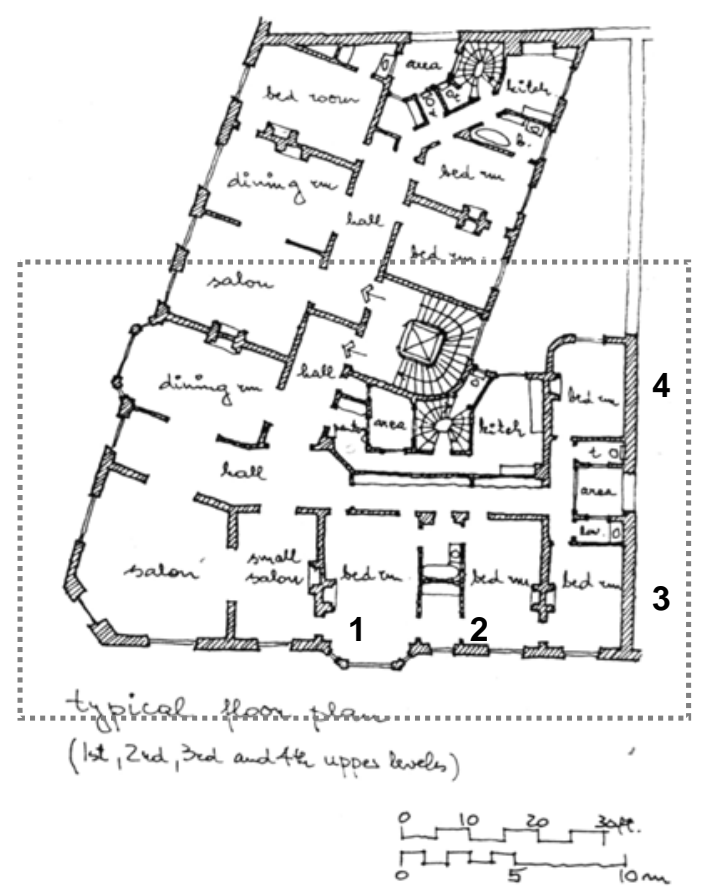

Segundo prof. Dr. TRAMONTANO, Marcelo ${ }^{16}$, esta separação permanece Nos apartamentos paulistas até hoje.

Fig. I 52 Apartamento a rua Theodore de Banville Fonte: SHOENAUER

\footnotetext{
${ }^{16}$ TRAMONTANO, Marcelo 1998 "Novos Modelos de Vida, Novos Espaços de Morar, uma reflexão sobre a Habitação Contemporânea, Paris, São Paulo, Tóquio" Tese de doutorado CPG FAU USP.
} 
Tabela 18 -Apartamento a rua Theodore de Banville Fonte: autor

Área total construída $=313,00 \mathrm{~m}^{2}$

\begin{tabular}{c|c|c}
\hline AMBIENTE & USO/ FUNÇÃO & ÁREAS $\left(\mathrm{m}^{2}\right)$ \\
\hline Vestíbulo & Recepção & $2.00 \times 6.35=12.70$ \\
\hline Sala de jantar & Refeições & $3.85 \times 6.80=26,18$ \\
\hline Cozinha & Preparo de Alimentos & $4.35 \times 3.00=13,05$ \\
\hline Banheiro & Bacia Sanitária & $2.00 \times 1.00=2,00$ \\
\hline Lavatório & Higiene pessol & $2.00 \times 1.00=2,00$ \\
\hline Dormitório 1 & Dormir/ Repouso/ Estar & $4.15 \times 6.30 \sim=25,00$ \\
\hline Dormitório 2 & Dormir/ Repouso/ Estar & $3.40 \times 5.45=18,53$ \\
\hline Dormitório 3 & Dormir/ Repouso/ Estar & $3.30 \times 4.40=14,52$ \\
\hline Dormitório 4 & Dormir/ Repouso/ Estar & $3.24 \times 4.05=13,12$ \\
\hline Circulação & União Entre Ambientes & $\sim 40,00$ \\
\hline
\end{tabular}

\subsubsection{Apartamentos em Londres 1853}

Apartamentos para classe alta, atenção aos cuidados construtivos, para proteção contra incêndios. Cabe ressaltar que durante o século XIX a sociedade britânica relutava em morar em apartamentos, a família tradicional preferia uma rua residencial tranqüila a uma rua de tráfego intenso, mas central. A maior empecilho a este tipo de moradia era a proliferação de doenças.

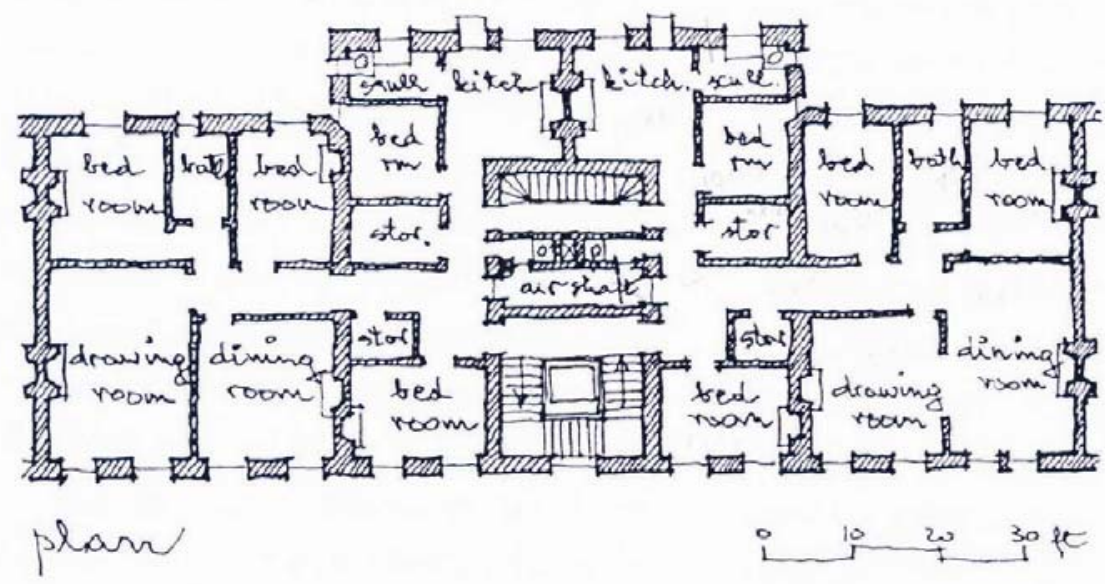

Fig. I 53 -Apartamento a Victoria Street Fonte: SCHOENAUER 


\subsection{Residências Entre Duas Guerras Mundiais 1900 - 1950}

A industrialização e as duas Guerras Mundiais trouxeram grandes alterações econômicas, sociais e técnicas. Nos estados desenvolvidos a maioria das pessoas já não vivia mais no campo e nem trabalhava no setor agrícola. Trabalhavam nas grandes cidades e viviam em Blocos Habitacionais.

As condições de higiene (água corrente e saneamento) eram quase sempre insuficientes, assim como a privacidade e o arejamento das habitações. Porém, no início do século $X X$ a reação contra a situação desumana foi o incitamento a um "Regresso à Natureza" pois a população acreditava na oportunidade de se construir "um mundo melhor".

Na virada do século XIX para o século XX, tivemos o movimento "Arts and Crafts" (Artes e Ofícios) iniciando o chamado "Revival Domestic", com vistas à revitalização dos projetos habitacionais. Formaram o grupo de arquitetos "Art Workers'Guild", seus seguidores comprometeram-se com a melhoria das habitações, buscando inspiração nos edifícios rurais ingleses, ficaram conhecidos como arquitetos de estilo livre "Free Style". Tendo como principais características: a simplicidade, a informalidade, a salubridade, o uso de mão de obra qualificada e grande respeito pelo meio ambiente.Esses novos paradigmas (cozinhas e quartos compactos, sala espaçosas que permitiam o convívio familiar) impulsionaram a relação com o espaço externo (contato com o ar) e a criação de ambientes para recreação (padrões novos desejados pelos proprietários e inquilinos). O funcionalismo e a praticidade nas habitações se tornaram um legado do Movimento Moderno.

\subsubsection{Cidades Jardim}

Após a Revolução Industrial, a maior obsessão dos moradores das cidades era a natureza e a busca pela salubridade.Dois grandes exemplos de êxito foram as Cidades Jardim de Hampstead (Henrietta Barnett) e Letchworth (Ebenezer Howard). 


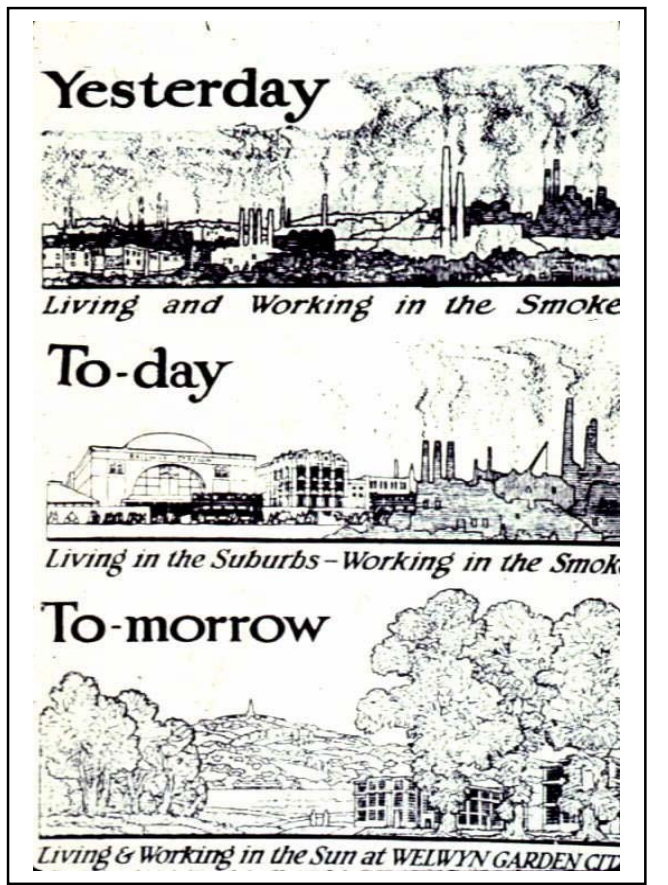

Fig.I 54 Imagens Ilustrativas de Welwyn Garden City, 20 anos depois de Lenchworth, Inglaterra Fonte:http://www.rickmansworthherts.freeserve.co .uk/howard2.htm

\subsubsection{Hampstead}

Iniciou-se devido aos esforços de Henrietta Barnett em construir um bairro jardim com habitações desejáveis e modestas, disponíveis a um largo segmento da sociedade, concebido em harmonia com o ambiente.

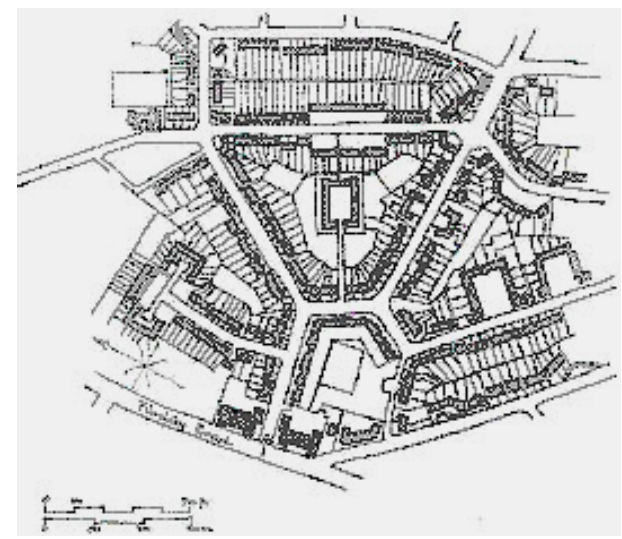

Fig. I 55 Cidade Jardim - Hampstead Fonte: SCHOENAUER 


\subsubsection{Letchworth}

Propunha, uma nova política para a cidade, aliviando a pressão dos grandes centros urbanos congestionados e para o espírito humano empobrecido. 1. Prevenção ao ciclo especulativo da terra por meio da propriedade permanente, toda a área de desenvolvimento urbano seria municipalizada, tornando-se propriedade privada por arrendamento.

2. Contenção da população restrita em até 30.000 habitantes.

3. Interdependência dos padrões de desenvolvimento urbano e rural.

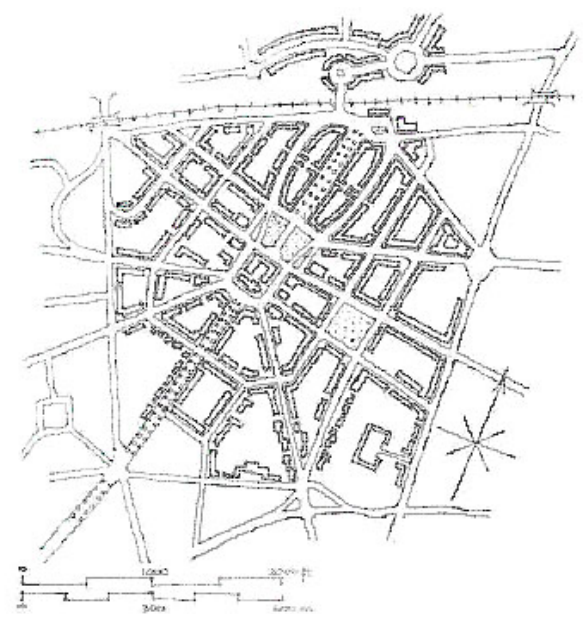

Fig.I 56 Cidade Jardim - Letchworth 1904 Fonte: SCHOENAUER

Em volta de um parque central deveriam agrupar-se casas (de 1 a 2 pavimentos) com jardins no lado e na frente ao longo de pequenas ruas arborizadas. O comércio e o trabalho deveriam juntar as vantagens da vida na cidade com as do campo. Porém, não foi possível manter a independência face às metrópoles e logo as cidades jardim transformariam em dormitórios de subúrbio.

Exemplo: Letchworth

Edifício multifamiliar - Quadrângulo $(60,00 \times 60,00 \mathrm{~m})$ bloco com área verde central e comum $(40,00 \times 30,00 \mathrm{~m})=1.200,00 \mathrm{~m}^{2}$ 
Tabela 19- Cidade Jardim - Letchworth Fonte autor

\begin{tabular}{c|c|c}
\hline AMBIENTE & USO/ FUNÇÃO & ÁREA(M $\left.{ }^{2}\right)$ \\
\hline VESTíBULO & Acesso/ distribuição & 5,40 \\
\hline SALA DE ESTAR & Receber/ & 13,60 \\
\hline COZINHA & Preparo de alimentos & 4,00 \\
\hline DORMITÓRIO & repouso & $10,80 e 12,60$ \\
\hline BANHEIRO & Higiêne & 12,60 \\
\hline
\end{tabular}
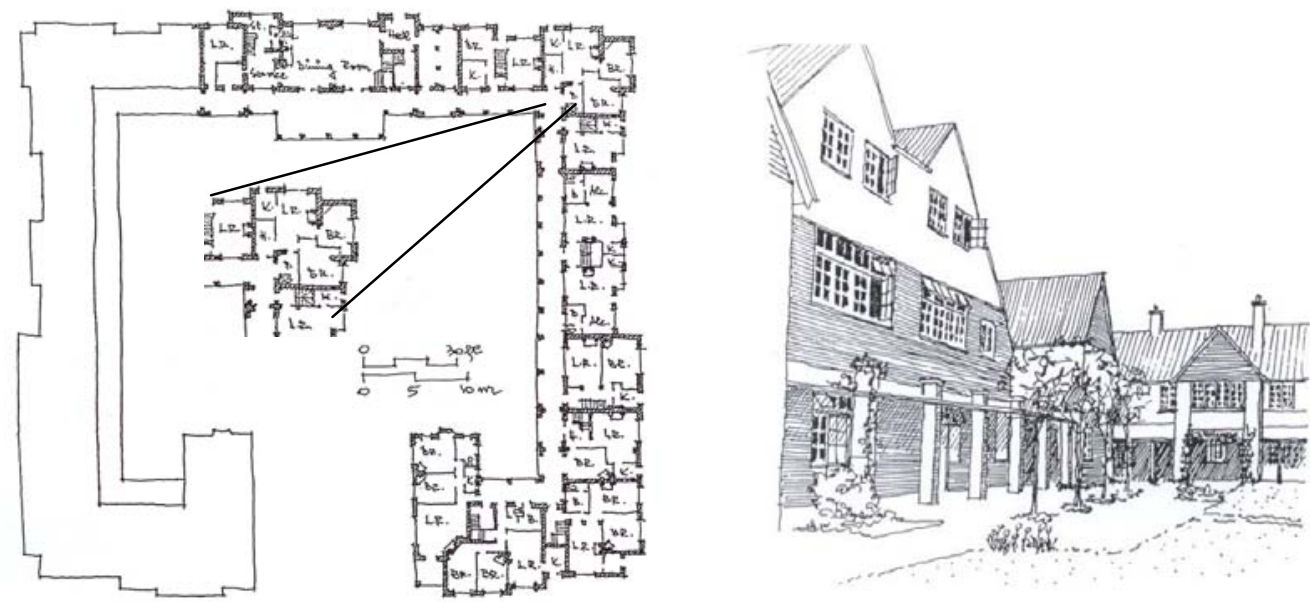

Fig. I 57 Cidade Jardim - Letchworth 1904

Vista interna e planta Inglaterra

Fonte: SCHOENAUER, com indicações do autor

\subsubsection{Estados Unidos}

Com o crescimento da indústria automobilística os subúrbios tornaram-se mais acessíveis proporcionando uma fuga em massa da área urbana. Conseqüentemente houve um grande aumento de residências menores e portanto mais baratas, mas que possibilitavam um contato com o meio ambiente.

Surgem também os "Gardens Apartments", que criavam a ilusão de casa com jardim, agora com um enfoque para as residências de alto padrão. Nota-se :

- a utilização de vestíbulo para a distribuição adequada dos ambientes, ao invés da galeria que unia os dormitórios que ainda vinha da idade média, 
- um maior cuidado com a localização das portas e janelas otimizando o layout para o mobiliário.

- um considerável aumento na dimensão dos dormitórios com uma inovação, a criação de closets.Podemos também imaginar que os quartos de vestir diminuíram e foram denominados closets.

Wright, um dos arquitetos americanos mais conhecido no período entre as Guerras Mundiais cria casas em harmonia com os ambientes naturais, onde cada função é bem definida, tendo a preocupação com a espacialidade (faz uso de janelas ao redor das residências para criar tal efeito) e integração dos ambientes, sendo um deles a cozinha. Surge então a denominada Planta livre e muitas portas consideradas desnecessárias são removidas, segundo SHOENAUER.Neste projeto em específico a insolação foi estudada para permitir a entrada de sol durante o inverno. Em contrapartida no verão o sol é barrado devido à disposição do beiral. As paredes possuem uma proteção térmica.

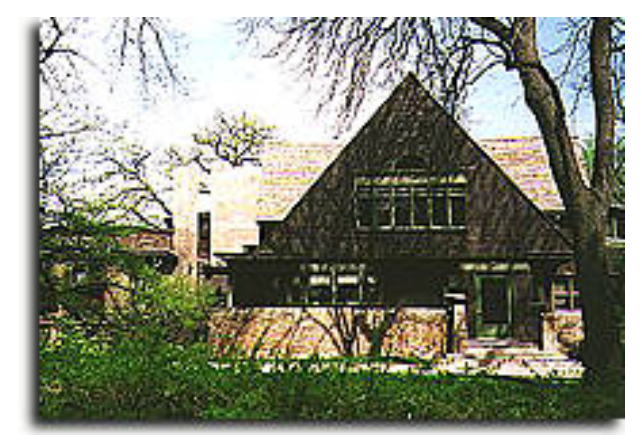

Fig.I 58 Imagem Ilustrativa Oak Park Home Frank Lloyd Wright, Chicago 1889 Fonte: Housingmagem:www.cbe.org.uk/ Chicago\%20visit/Photographs\%20...(foto)6

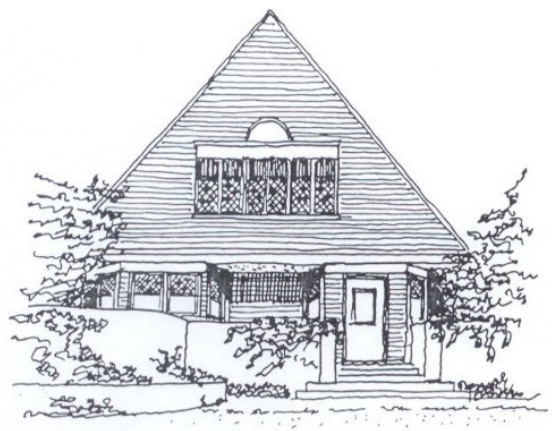

Fig. I 59 Oak Park Home Elevação Frontal Frank Lloyd Wright, Chicago 1889 Fonte SCHOENAUER

Tabela 20 Oak Park Home Frank Lloyd Wright, Chicago Fonte autor

\begin{tabular}{l|c|c}
\hline \multicolumn{1}{c|}{ AMBIENTE } & USO/ FUNÇÃO & ÁREA $\left(\mathrm{M}^{2}\right)$ \\
\hline VESTÍBULO & Acesso & 9,00 \\
\hline S. ESTAR & Receber/estar & 22,00 \\
\hline S. JANTAR & Refeições & $5,65 \times 3,08=17,40$ \\
\hline ESTUDOS & Leitura/estudo & $3,00 \times 4,00=12,00$ \\
\hline S. TRABALHOS & Trabalhar & 6,00 \\
\hline COZINHA & Preparo de alimentos & $3,00 \times 4,25=12,75$ \\
\hline
\end{tabular}




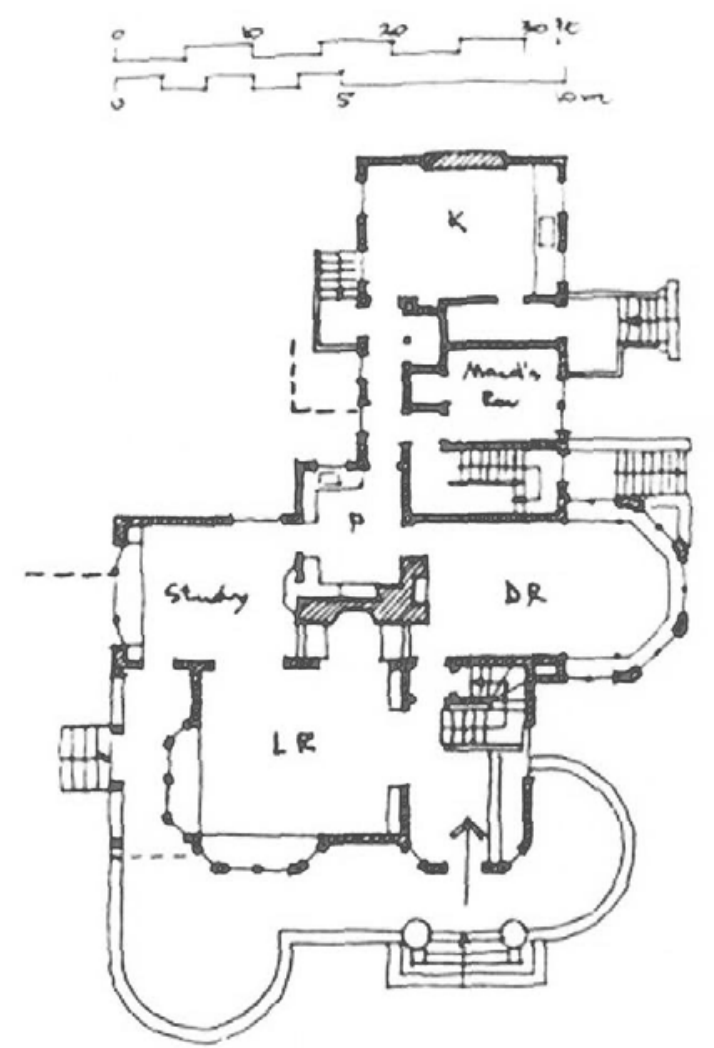

Fig. I 60 Planta Pav. TérreoOak Park Home

Frank Lloyd Wright, Chicago 1889

Fonte: SHOENAUER

\subsection{3. Índia - O Bangalô}

Teve origem na adaptação das habitações nas colônias inglesas de Bengala.Devido ao clima quente e úmido. O bangalô indiano é uma moradia unifamiliar de pavimento único. A cozinha é separada.

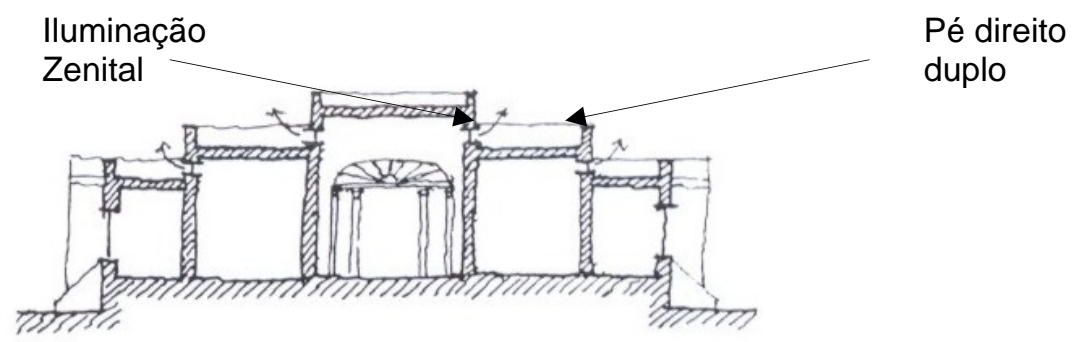

Fig. 61 Corte Bangalô Indiano

Fonte: SHOENAUER 


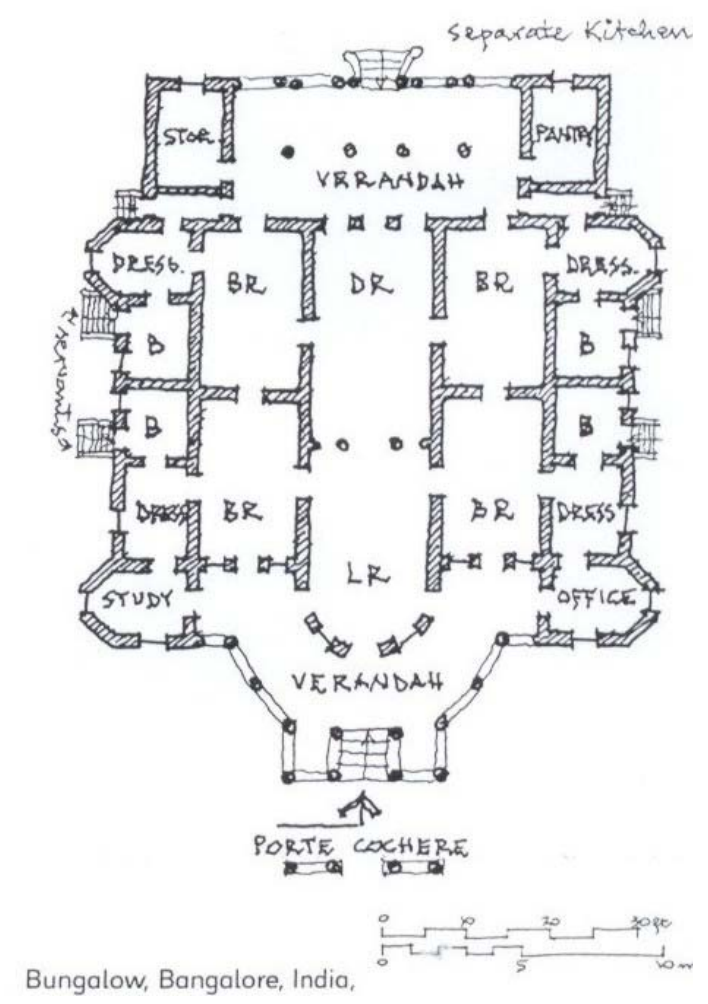

Fig. I 62 Planta Bangalô Indiano

Fonte : SCHOENAUER
Tabela 21 Bangalô Indiano

Fonte : autor

Área construída aproximada - 225,00 m²

\begin{tabular}{l|c|c}
\hline \multicolumn{1}{c|}{ AMBIENTE } & USO/ FUNÇÃO & ÁREA $\left(\mathrm{m}^{2}\right)$ \\
\hline VARANDA & Acesso/Comtemplação & 5,40 \\
\hline ESTUDOS & Ler/ estudar & 13,60 \\
\hline S. ESTAR & Receber & 4,00 \\
\hline S.JANTAR & Repouso & $10,80 \mathrm{e}$ \\
\hline DOMRMITÓRIOS & Refeições & 12,60 \\
\hline Q. DE VESTIR & Trocar De Roupas & 7,00 \\
\hline BANHEIRO & Higiêne & 5,70 \\
\hline DEPÓSITO & Guarda de Objetos & 8,40 \\
\hline
\end{tabular}

\subsubsection{França}

Assim como na América, a França possuía também um arquiteto famoso, que mesmo amando o crescimento da cidade preocupava-se com a questão do bem estar. Le Corbusier previu que com a diminuição da carga horária de trabalho as rotinas familiares sofreriam alterações. Mais do que isso, constatou também que as residências encontravam-se em condições precárias que não poderiam ser ignoradas. Portanto, adotou plantas livres, proporcionado espaços abertos. Fez uso do pilotis, elevando as casas, evitando seu contato com o solo úmido, permitindo que o terreno continuasse integrando ao jardim.Nos conjuntos 
habitacionais inovou criando estacionamentos, restaurantes e cafés, pois as pessoas precisavam de mais facilidades.
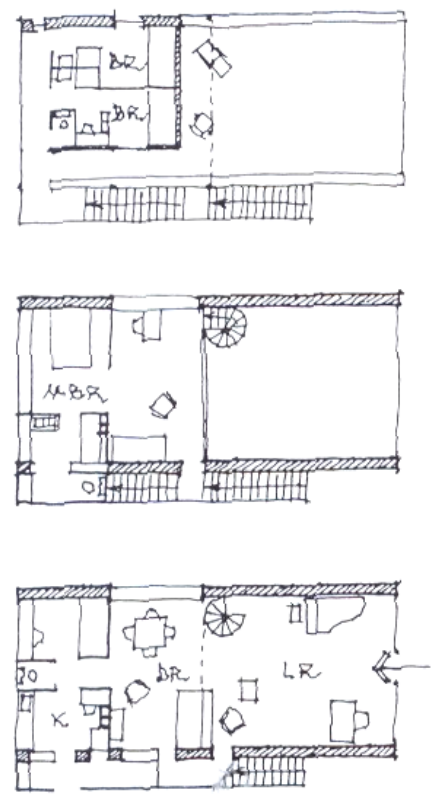

Maison 'Citrohan' (1920), three plans and perspective, Le Corbusier

\{after W. Boesiger and $H$. Girsberger)

Fig.I 63 Plantas

Maison Citroham 1920, Le Corbusier Fonte: SCHOENAUER

\subsubsection{Alemanha}

$\mathrm{Na}$ Alemanha, assim como na França houve a reconstrução das cidades devastadas pela guerra. Surgem também os Superblocos (que deveria ter um "Espírito Coletivo"). Os apartamentos são menores, porém os espaços são bem iluminados, possuindo banheiro exclusivo do apartamento, ventilação cruzada e aquecimento central. 


\subsubsection{América Latina}

Especificamente no Brasil observamos uma forte influência de Le Corbusier nas construções de Oscar Niemeyer no projeto residencial para o Rio de Janeiro, utilizou algumas técnicas adotadas por Corbusier na França. Fez uso de pilotis; grandes vãos proporcionando boa ventilação e iluminação. Nota-se também as mesmas preocupações com a questão da recreação, facilidades, tempo livre (novo conceito para criação das residências).

\subsection{Século XX de 1950 a 2000}

Nesse último período, até os dias de hoje, foram levantadas tipologias de casas relacionadas ao contexto urbano da Civilização Ocidental.

Assim, as moradias são inseridas nas cidades, onde são consideradas todas as necessidades e possibilidades inerentes ao meio urbano, como por exemplo, as tecnologias disponíveis, utilizadas nos edifícios de até 100 andares; o adensamento populacional, verificado nos conjuntos residenciais populares; a falta de espaço nas cidades, observado nos lotes urbanos estreitos; a integração da moradia com o trabalho dos grandes centros urbanos, ou então, por opção, busca-se alternativas que apresentem qualidade de vida melhor, fugindo-se do caos urbano, como nas casas suburbanas, nas casas-pátio, nos condomínios, até chegar a uma proposta de novo urbanismo, com ênfase no ser humano, e não na estrutura urbana por ele criada

\subsubsection{Casa Suburbana Americana}

Esse tipo de habitação surge no período do Pós $2^{\mathrm{a}}$ Guerra, décadas de 50 e 60, na América do Norte, com a sociedade do pós-guerra americana em prosperidade, em 1949, 24,5\% das famílias americanas tem 5 ou mais pessoas, e na sua maioria são casais jovens com crianças.

O automóvel passa a ser necessidade, tornando-se elemento importante no programa das casas. Possuindo zonas de lazer e descanso, de comer e higiene; e apresenta basicamente duas tipologias: 
Tipo 1 - casa com ambientes de estar, cozinha, 2 dormitórios e banheiro; com área total de $74,32 \mathrm{~m}^{2}$.

Tipo 2 - casa com salas de estar c/ lareira e jantar, cozinha, 3 dormitórios (uma suíte), banheiro social, além de depósito e garagem p/ 2 carros; com área total de $83,61 \mathrm{~m}^{2}$.

\subsubsection{Casa Pátio Ou Casa Jardim}

Surge na Alemanha, nas décadas de 20 e 30 , e populariza-se também no período do Pós $2^{\mathrm{a}}$ Guerra, já nas décadas de 50 e 60 , em toda a Europa (Alemanha, Dinamarca e Grã-Bretanha) e na América. Há melhor aceitação do público europeu, em relação ao americano.

As casas pátio, com vista interna são mais seguras e invioláveis do que as casas com aberturas e visual ao exterior.Constata-se que a relação de vizinhança, ao contrário do que se possa parecer pelo isolamento, é menos estratificada, havendo uma maior relação social entre as famílias.São casas térreas em forma de "L", ou mesmo lineares e estreitas, e como característica principal possuem pátios ou jardins, internos e murados.

Os principais ambientes internos, as salas e dormitórios voltados para os pátios descobertos, onde se busca maior privacidade acústica e visual, através do isolamento dos espaços externos, os pátios. Às vezes têm garagem.

O programa dessas casas acompanha a mesma característica do período, possuindo zonas de lazer e descanso, de comer e higiene.

Em alguns estudos, foi proposta uma modulação nas dimensões apresentando medidas padronizadas, com áreas construídas seguindo esses módulos: $92,0 \mathrm{~m}^{2}(7,2 \mathrm{~m} \times 7,8 \mathrm{~m})$ ou $100,0 \mathrm{~m}^{2}(10 \mathrm{~m} \times$ $10 \mathrm{~m})$. As similaridades dos projetos de Mies Van der Rohe e Jorn Utzon ilustram o citado a cima:

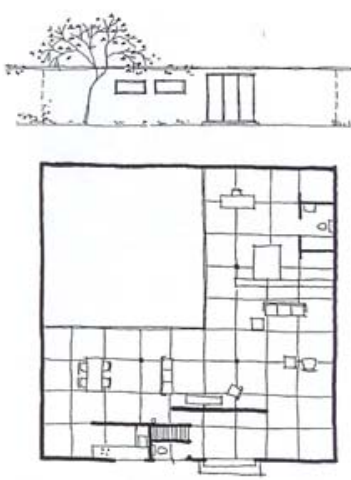

Fig. I 64 Plantas Casa Pátio Ludwing Mies Van der Rohe 1931 Fonte: SCHOENAUER 


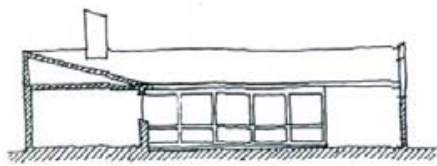

Tabela 22 - Casa Pátio Jorn Utzon

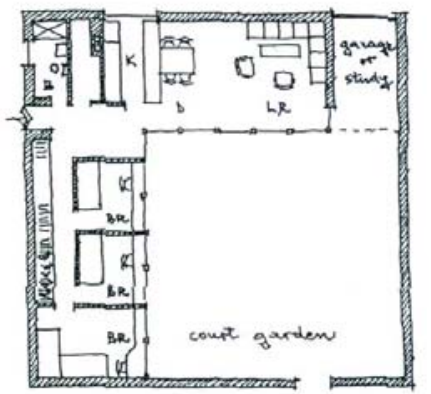

Área total construída $=125,00 \mathrm{~m}^{2}$

\begin{tabular}{c|c|c}
\hline AMBIENTE & FUNÇÃO/ USO & ÁREA(M $\left.{ }^{2}\right)$ \\
\hline S. JANTAR E ESTAR & Receber/ refeições/ estar & 26,00 \\
\hline GARAGEM/ ESTUDIO & Abrigo/ trabalho & 12,00 \\
\hline COZINHA & Preparo de alimentos & 6,00 \\
\hline DORMITÓRIOS & descanso & 8 a 12,20 \\
\hline BANHEIROS & higiene & 3,60 \\
\hline PÁTIO & Lazer/ vent. E iluminação & 100,00 \\
\hline
\end{tabular}

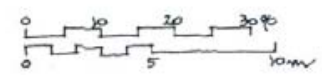

Fig.I 65 - Planta Casa Pátio Jorn Utzon Fonte: SCHOENAUER

\subsubsection{Casa Urbana Geminada}

Originárias das casas lineares do século XIX, este tipo de casa urbana surge apenas a partir do $4^{\circ}$ quadrante do século $X X$, nas décadas de 60 a 90, na Europa (Suíça, Suécia e Dinamarca), e na América (E.U.A. e Canadá), quando
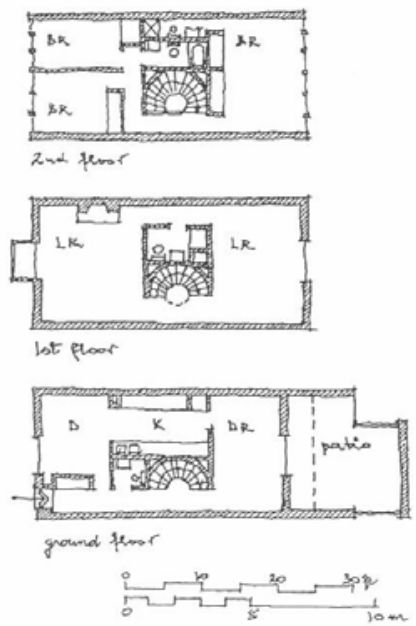

Fig.I 66 - Plantas Casa Geminada

I.M. Pei os padrões espaciais das casas isoladas são aplicados as casas em lotes urbanos, estreitos. As restrições ficam pela falta de garagens cobertas. As casas urbanas têm aberturas para a rua e visual para o exterior, é oposto ao que se apresenta nas casas jardim. O programa dessas casas também acompanha a mesma característica do período quanto as com zonas residenciais, a saber; de lazer, descanso, preparo de refeições e higiene bem definidos por pavimentos, onde os ambientes sociais (salas de estar e jantar) e de serviço (cozinha) são localizados nos pavimentos térreos, por 
vezes incorporados a um quintal, dormitórios e banheiros ficam em pavimentos superiores.Possuem área construída em média de aproximadamente 108,0m² para os sobrados, em 2 pavimentos de 4,5m x 12,0m.

Tabela 23 Casa Geminada - projeto de I.M. Pei .

Washington Square East town houses, Philadelfia Fonte autor

\begin{tabular}{c|c|c|l}
\hline & AMBIENTE & USO/ FUNÇÃO & \multicolumn{1}{c}{ ÁREA $\left(\mathrm{m}^{2}\right)$} \\
\hline \multirow{4}{*}{$2^{\circ}$ Pavimento } & Dormitório 1 & Repouso/Dormir & $2,00 \times 3,50=7,60$ \\
\cline { 2 - 4 } & Dormitório 2 & Repouso/Dormir & $2,45 \times 3.50=8,50$ \\
\cline { 2 - 4 } & Dormitório 3 & Repouso/Dormir & $4.55 \times 3.75=17,50$ \\
\cline { 2 - 4 } & Banheiro 1 & Higiene & $2.46 \times .80=2,00$ \\
\cline { 2 - 4 } & Banheiro 2 & Higiene & $2.46 \times 1.00=2,46$ \\
\cline { 2 - 4 } & Circulação & Unir ambientes e pavimentos & 8,78 \\
\hline \multirow{3}{*}{$1^{\circ}$ Pavimento } & Sal estar lareira & Reunião familiar & $4.18 \times 4.75=19,75$ \\
\cline { 2 - 4 } & Sala estar & Reunião visitas & $3.50 \times 4.75=16,60$ \\
\cline { 2 - 4 } & Circulação & Unir ambientes e pavimentos & 7,96 \\
\cline { 2 - 4 } & Banheiro & Higiene & $1.30 \times 2.40=3,12$ \\
\hline \multirow{2}{*}{ Térreo } & Cozinha & Cozinha & $3.80 \times 2.45=9,31$ \\
\cline { 2 - 4 } & Sala jantar & Fazer refeições e acesso & $2,81 \times 4.65=13,00$ \\
\hline
\end{tabular}

\subsubsection{Edifício Alto De Apartamentos Populares}

Surge nas décadas de 50 e 60, até os anos 80, principalmente nas grandes cidades americanas (Chicago e Nova York).

O público alvo é de americanos ricos com estilo de vida urbano, onde o conforto do cotidiano prevalece à suntuosidade formal na definição dos espaços e dos ambientes.Contudo, apresentam custos altos com sistemas de segurança, ar condicionado, e serviços de hotelaria e lazer.

As unidades residenciais são apartamentos de alto padrão em edifícios monolíticos altos de 20 a 40 pavimentos, onde são aplicados os princípios do Movimento Moderno, com fachadas em peles de vidro em estruturas metálicas ou de concreto.Adotam as mesmas características programáticas das casas do período, possuindo zonas distintas de lazer e descanso, de comer e higiene.

Os apartamentos são amplos, de 80,0 a $120,0 \mathrm{~m}^{2}$, com alguns chegando até $\pm 200,0 \mathrm{~m}^{2}$. Têm salas em "L", para 2 ambientes (estar e jantar); 
dormitórios (suítes) e banheiros em zona isolada, acessada por corredor, copa, área de serviço e dependências são tratados como supérfluos.

Exemplo: Silver Towers - Projeto de I.M. Pei And Associates Nova York (1967)

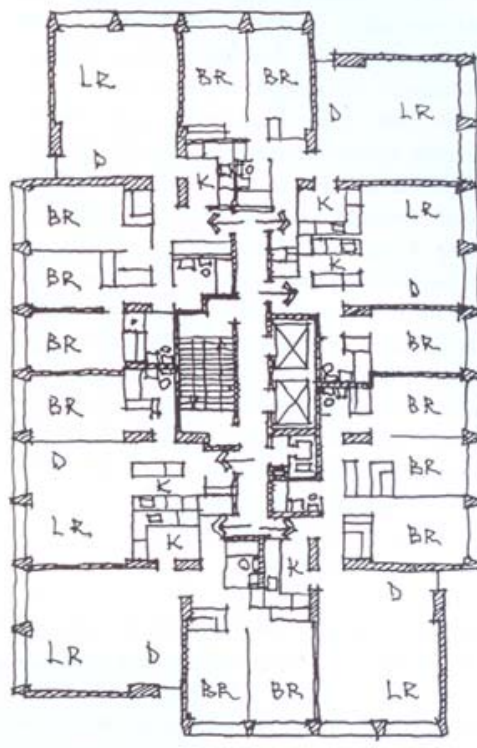

Tabela 24 Prédio de apartamentos Silver Tower Nova York - 1963 I.M. PEI

\begin{tabular}{c|c|c}
\hline AMBIENTE & FUNÇÃO/ USO & AREA $\left(\mathrm{m}^{2}\right)$ \\
\hline S.JANTAR & Receber/ Refeições/ Estar & 38,50 \\
\hline COZINHA & Preparo de Alimentos & 7,50 \\
\hline DORMITÓRIOS & Repouso/Dormir & 12,00 a 15,00 \\
\hline BANHEIRO & Higiene & 3,60
\end{tabular}

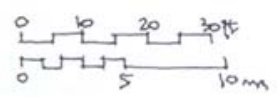

Silver Towers, New York City (1967)

1. M. Pei and Associates

(ofter Y. Ashihara)

Fig. I 67 Silver Towers -I.M. Pei and Associates

Nova York (1967)

Fonte SCHOENAUER

\subsubsection{Edifício De Apartamentos Populares}

Surge no período do Pós $2^{\mathrm{a}}$ Guerra, nas décadas de 50 e 60, nas grandes cidades da América e da Europa, mais precisamente na Grã-Bretanha e França. Também em Hong Kong. São empreendimentos destinados às classes mais populares. Este conjuntos foram caracterizados pelo vandalismo e falta de segurança, com deterioração das áreas comuns e públicas, na proporção direta à altura dos prédios.

Os apartamentos são simples, com o mesmo programa das casas do período, possuindo as zonas de lazer e descanso, de refeições e higiene. Inicialmente entregues sem acabamentos, tem sala, 2 ou 3 dormitórios, banheiro e cozinha, com área total aproximada de $60,00 \mathrm{~m}^{2}$. 


\subsubsection{Edifício Residencial Isolado}

Esta tipologia se consolida no início da $2^{\mathrm{a}}$ metade do século $\mathrm{XX}$, na década de 50, basicamente na Europa, em países como Suécia, Alemanha, França, Dinamarca, e até na URSS, onde obteve popularidade apesar da paisagem monótona e da má manutenção dos edifícios ali verificada.

São destinados à classe média, e diferente dos edifícios monolíticos de alto padrão. Este tipo de edifício isolado permite ventilação cruzada em diagonal, por duas faces de fachada, além de uma circulação central íntima entre os apartamentos, com melhor controle sobre a ocupação dos mesmos.Com zonas de lazer e descanso, de comer e higiene, tem sala, 2 ou 3 dormitórios, banheiro e cozinha. Sua área total varia de $\pm 60,00 \mathrm{~m}^{2}$ a $90,00 \mathrm{~m}^{2}$.

\subsubsection{Edifício Misto}

Proposta inovadora surgida nas décadas de 60 a 80, nas grandes cidades da América do Norte (EUA e Canadá) e na Itália. No Pós Guerra, propõe-se a retomada das áreas centrais das cidades para a moradia, integrando as atividades de trabalho. Assim, a moradia, junto ao local de trabalho, dentro da cidade, permite uma otimização do tranporte, reduzindo o trânsito e a poluição do ar.

Surgem então empreendimentos que integram a moradia a atividades comerciais, com implantação de edifícios residenciais, de escritórios, e centros comerciais e de serviços, todos em uma mesma quadra.Também se apresentam propostas onde as atividades de moradia e de trabalho estão integradas num mesmo edifício, com apartamentos e locais de trabalho, como escritórios, centros comerciais e de lazer, além de áreas de estacionamento de veículos.

As tipologias são variadas, desde apartamentos tipo estúdio, com um único ambiente(com função de dormir e estar), cozinha e banheiro, até apartamentos com programa típico de casas, com até 4 dormitórios. As áreas e dimensões também são muito variadas, de $50,00 \mathrm{~m}^{2}$ a $150,00 \mathrm{~m}^{2}$ de área construída.

Exemplo: 


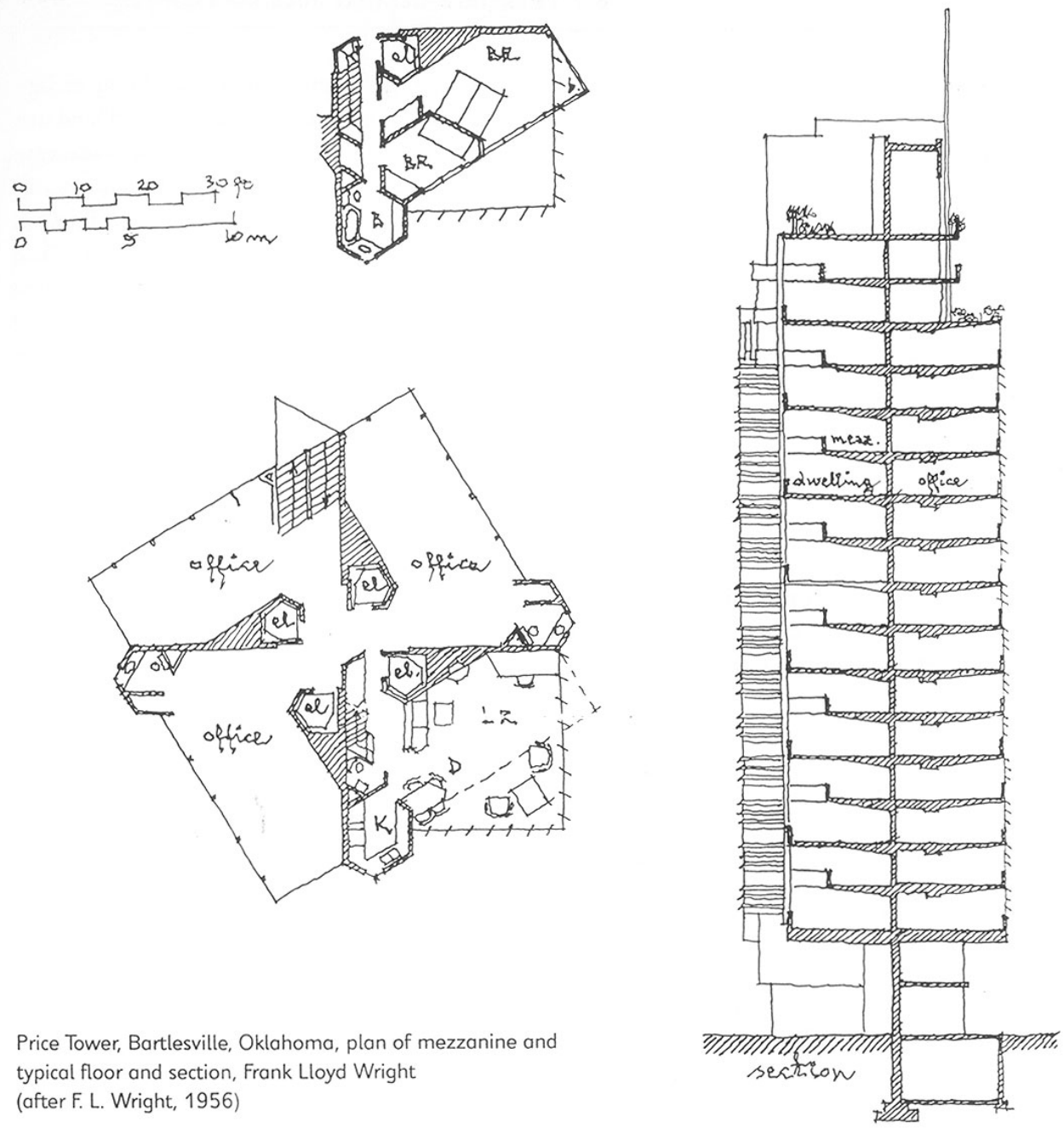

Fig. I 68 Plantas e Corte Price Tower, Bartlesville Oklahoma Frank Lloyd Wright Fonte: SCHOENAUER

\subsubsection{Habitação Coletiva - Condomínios}

Surge primeiro na Dinamarca, nas décadas de 70 a 80, espalhandose depois no resto da Europa e na América. Tem como proposta; ideais utópicos da contra-cultura dos anos 60, que são associados a pressão socioeconômica das famílias, e ao interesse por moradias de custo mais baixo.

Caracterizados por grupos de casas, que podem ser isoladas ou geminadas, térreas ou sobrados; sendo implantadas como vilas ou condomínios, com acesso a espaço comunitário para serviços e lazer. 
O programa dessas casas também acompanha a mesma característica da casa urbana, com zonas de lazer, descanso, de comer e higiene bem definidos, onde possuem salas de estar e jantar, cozinha, 2 a 4 dormitórios, banheiro social; e têm áreas construídas variando de $80,00 \mathrm{~m}^{2}$ a $150,00 \mathrm{~m}^{2}$. Externamente à unidade habitacional, as atividades de lazer e serviço são comunitários, com área comum para estacionamento, centro comunitário com cozinha equipada, refeitório, creche, sala de TV, sala de jogos, lavanderia e sauna com vestiário.

\subsubsection{Edifício Convertido Em Residência - Loft's}

Ocorre no período do Pós $2^{\mathrm{a}}$ Guerra, nas décadas de 50 e 60, principalmente nos Estados Unidos. Surge a partir do abandono dos edifícios pelas industrias nas áreas centrais das cidades, quando artistas ocupam os galpões abandonados no Soho, em Nova York, por contar com aluguéis baixos e espaço físico para seus trabalhos artísticos, adaptando-os como espaços de morar e de trabalho.

O programa pode ser bastante alternativo, com ambientes de pé direito alto com as funções de estar, jantar e cozinhar associadas a função de produção (de trabalho). São feitas adaptações para dormitórios e banheiro. As áreas construídas apresentadas são muito variadas, conforme o espaço aproveitável dos edifícios, chegando até a $200,0 m^{2}$. Não possuem garagem.

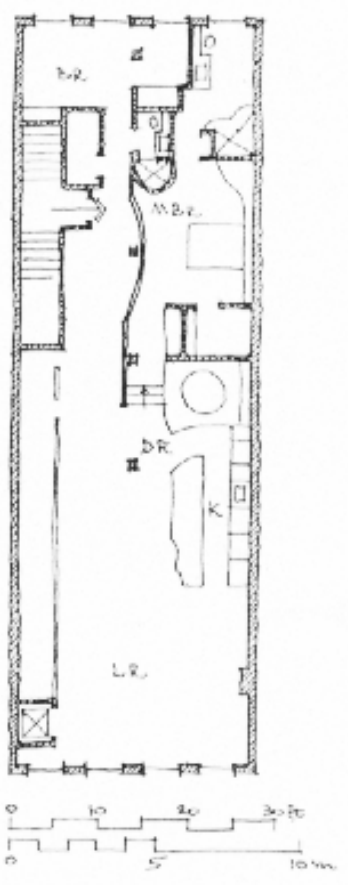

Loft dwelling, New York City, Alan Burhsboum ond Stephen Tilly

(after Mildred F. Schmertz)

Fig. I 69 Planta Loft Alan Burchsboum Nova York Fonte SCHOENAUER 


\subsubsection{Novo Urbanismo}

Surge na França, na década de 60, e desenvolve-se na década de 80 nos Estados Unidos, tendo como conceito um desenho urbano baseado nos padrões de desenvolvimento tradicionais, em oposição à racionalidade das áreas urbanas preconizadas pelo Modernismo.As comunidades são pensadas para pessoas, e não carros, com ênfase no tráfego de pedestres, e acesso restrito de veículos, e havendo a interação de vizinhança de modo natural.

São áreas residenciais, de ocupação urbana tradicional, com serviços e comércio, e apresentam edifícios de meia altura ou sobrados isolados, com arquitetura neotradicional, e ambiente contemporâneo de planos livres.

As tipologias apresentadas são de casas e apartamentos com programa característico das casas urbanas do período, com zonas de lazer, descanso, refeições e higiene bem definidos, com ambientes de estar e jantar, cozinha, 2 a 4 dormitórios e banheiro social.

As áreas construídas apresentadas são muito variadas, chegando até a $200,00 m^{2}$. Assim como nas casas de condomínio, externamente à residência, as atividades de lazer e serviço são comunitárias; e também apresenta área comum para estacionamento. 


\section{PARTE II \\ A Dimensão nas Habitações Paulistas}

Para que se possa ter uma referencia histórica da evolução das dimensões nas habitações paulistanas, foram feitas considerações sobre as casas de moradia da época de colônia, evoluindo até os palacetes paulistanos da época do café e início da industrialização, concluindo com os primeiros edifícios residenciais construídos em São Paulo.

Um estudo comparativo com as formas de morar tradicionais paulistanas, é interessante não só pela evolução do modo de vida como pela variação de ambientes, ou seja, o uso/função de cada ambiente e conseqüentemente os seus dimensionamentos. Os programas das casas urbanas paulistas mais abastadas, bem como o modo de vida dos seus moradores, resultaram das superposições do processo de civilização urbano ao da civilização rural pré-existente.

Foram utilizados vários trabalhos do Prof. Dr. LEMOS, Carlos Alberto, como referencia na conceituação e compreensão do assunto abordado, principalmente os desenhos das plantas. O trabalho da pesquisadora HOMEM, Cecília também forneceu dados para esta etapa da pesquisa, principalmente no que se refere aos Palacetes Paulistanos da época do café tema de sua tese de doutorado. As citações serão referentes ao trabalho deste dois pesquisadores.

\section{Tempos de Colônia}

A casa brasileira inicialmente no tempo de colônia teve 2 tipos de influencias distintas a Ibérica e da casa do índio. A casa do índio era simples construída de paus (troncos) e palha, escura sem aberturas, abrigava as redes e a fogueira, as demais atividades eram feitas ao ar livre. O colono português trazia 2 tipos de habitações com características distintas; as casas do 
mediterrâneo; que eram de terra (taipa de pilão), de adobes ou tijolos cozidos sob um grande telhado que abrigava a família, empregados e estábulo e as casas do atlântico que eram construídas de pedras e fragmentadas em vários abrigos distintos cada qual com a sua função.O fogo como ponto de interesse principal servia para cozinhar e aquecer principalmente as casas do atlântico.Surgiram então as primeiras casas brasileiras resumo das influencias já citadas, eram de palha e paus, porém dividas de forma cristã ${ }^{17}$ isolando as atividades domésticas.

\subsection{Conjunto de Características que Influenciaram na Tipologia e na} Construção das Primeiras casas

Indicando uma adaptação ao novo continente estas residências formaram um conjunto de características próprias que construíram um tipo de arquitetura singular principalmente quanto aos programas de necessidades e alguns entraves de ordem técnica. Os 5 itens que mais influenciaram na arquitetura das casas aqui construídas foram :

1- Miscigenação - O mundo mameluco, da onde vinham as mulheres, pois o homens eram portugueses.

2- O clima - O clima tropical, faz com que o fogo deixe de ser o centro de interesse da casa tanto urbana como rural, diferente de Portugal, com a cozinha indo para fora da construção principal, devido principalmente a umidade do ar, segundo Lemos, pois em Portugal

“ mesmo no Algarve, tépido e de esguias chaminés o fogão e a cozinha são o centro de interesse da casa". ${ }^{18}$

3- Recursos do meio ambiente - muita madeira, a primeira fábrica de cal só aparece no século XVIII, até então se usava a cal dos sambaquis, muito úmida.

4- O "saber fazer ", como cita o prof. Dr. LEMOS, Carlos, foi adaptado, pois vieram portugueses tanto do atlântico como do mediterrâneo, porém, os os primeiros abrigos foram os ranchos indígenas.

\footnotetext{
${ }^{17}$ LEMOS. Carlos A ., 1993, passim - "Transformações do espaço habitacional, ocorridas na arquitetura brasileira do século XIX- Anais do Museu Paulista.

18 LEMOS, Carlos A. 1993 seq.
} 
"Surgindo assim as primeiras casas sincréticas nascidas da intervenção do branco nos trópicos"19 (o tejupar de palha).

5- Religião - As longas distancias entre as povoações e a precariedade dos caminhos dificultava a comunicação.Em Portugal todos moravam perto da igreja, enquanto no Brasil o exercício da vida religiosa era doméstico, feito dentro das moradias devido às longas distancias separando os latifúndios das cidades.

Para a real compreensão do funcionamento destas casas é importante ressaltar alguns aspectos comportamentais como a segregação feminina e o exercício das práticas religiosas, a primeira sendo responsável por duas zonas distintas nas casas, a íntima aonde se vivia e a social de receber, a hospitalidade era uma obrigação social devido as grandes distancias e a morosidade dos meios de locomoção, ela se dava tanto na casa urbana como na rural. A hospitalidade era oferecida mesmo a desconhecidos, os quartos de hóspedes próximos do acesso ainda serão encontrados no início do séc XX e final do século XIX, nos palacetes paulistanos.

\subsection{Casas de Cidades}

Com o surgimento de núcleos urbanos vieram as casas de cidades com um programa de necessidades bem mais simples do que as casas rurais, não tinham sob o seu teto nenhum processo de fabricação e tinham pouco uso, eram habitadas durante 2 ou 3 festas por ano, assim eram desprovidas de muitas divisões, usavam tecido e palha como divisórias leves.Já as casas dos artesãos que residiam nas cidades tinham 3 áreas distintas, a saber:

- local de trabalho,

- as alcovas e o alpendrado aos fundos

- a varanda - , durante muitos anos a varanda era aonde as pessoas faziam as refeições, era a área íntima da casa.

Esta planta (fig. 70) ilustra a casa urbana paulista dos séculos XVII e XVIII, clarificando a área de íntima e a área pública da casa.

${ }^{19}$ LEMOS, Carlos A., 1993, seq. 
Casa 1 área total construída $=130,00 \mathrm{~m}^{2}$

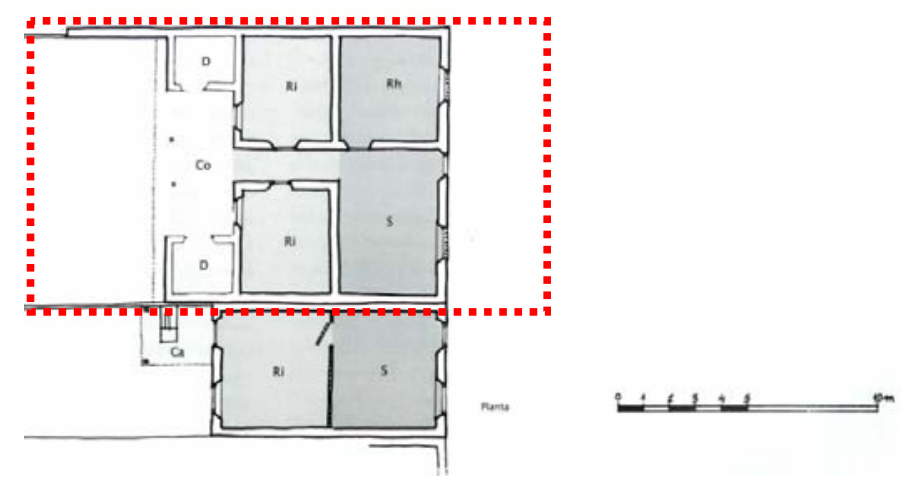

Fig.I 70 Planta Casas Urbanas Paulistas, séc XVII e XVIII.

Fonte:pag. 27, Casa Paulista - Carlos Lemos. 1999

Tabela 25 de Casas Urbanas Paulistas

Fonte: tabela autor

\begin{tabular}{c|c|c|c|c}
\hline SIGLAS & COMPARTIMENTOS & DIMENSÕES & ÁREA $\left(\mathrm{m}^{2}\right)$ & $\%$ \\
\hline $\mathrm{Rh}$ & Dormitório de Hospedes & $4,00 \times 4,00$ & 16,00 & 12,31 \\
\hline $\mathrm{S}$ & Sala & $4,00 \times 5,50$ & 22,00 & 16,92 \\
\hline $\mathrm{Ri}$ & Alcovas & $3,50 \times 4,00$ & 14,00 & 10,77 \\
\hline $\mathrm{Ri}$ & Alcovas & $3,50 \times 4,00$ & 14,00 & 10,77 \\
\hline $\mathrm{D} 1$ & Dependências - Serviços & $1,80 \times 2,30$ & 4,14 & 3,18 \\
\hline $\mathrm{D} 2$ & Dependências - Serviços & $2,00 \times 2,30$ & 4,60 & 3,54 \\
\hline $\mathrm{Co}$ & Alpendre & $5,50 \times 2,50$ & 13,75 & 10,58 \\
\hline
\end{tabular}

As alvenarias somam $41,40 \mathrm{~m}^{2}$, ou seja $32 \%$ da área construída, sendo maior que qualquer ambiente interno da casa, as paredes grossas serviam para absorver o calor (símbolo da técnica construtiva do desperdiço, possível pelo excesso material - madeira - e a mão de obra escrava), assim como os alpendres $^{20}$ junto às faces ensolaradas.

${ }^{20}$ alpendre não é varanda, segundo LEMOS, alpendre é uma cobertura situada fora do perímetro das paredes mestras de uma construção. 


\subsection{Casas Rurais}

Nas casas paulistas vemos principalmente, a chamada reentrância (varanda) não o alpendre pois, o clima aqui não o solicitava, este espaço aberto central (Palladiano, segundo, Lemos) foi encontrado na casa chamada bandeirista, era um espaço para o abrigo temporário de colheitas, e também servia de circulação (distribuição), muitas vezes ainda nas casas rurais, encontrávamos este espaço ladeado pela a Capela de um lado e pelo dormitório de hospedes do outro lado, ainda sendo incorporando o uso de sala de jantar e para receber visitas.

Atualmente estes espaços com função de ligação entre o externo e o interno, nas nossas habitações, costumam ser chamados de varandas, fazendo parte do programa de necessidades de qualquer apartamento na cidade de São Paulo, dando-se preferência a conformação de alpendre ou seja que não seja uma reentrância e sim tenha as três faces livres, avance do corpo do prédio.

Como exemplo é pertinente a Casa Engenho do Tatu em São Carlos, datada primeiro quartel do século XIX, pois tem alcovas localizadas no centro da casa dimensões reduzidas, distribuição muito

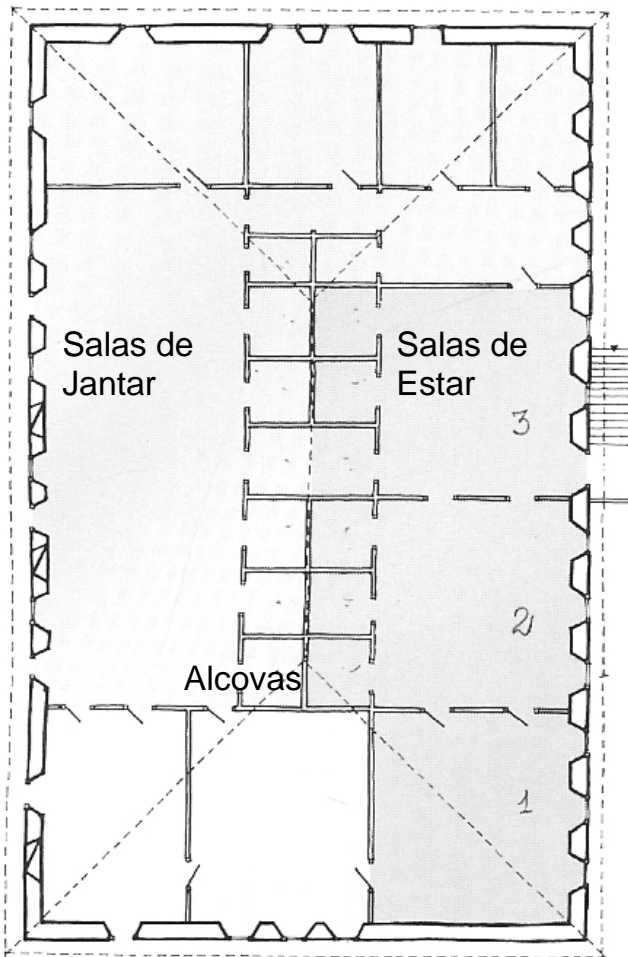
usada nas fazendas de café. A dimensão

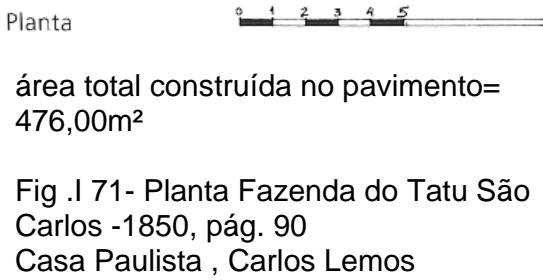

área total construída no pavimento=

Carlos -1850, pág. 90

Casa Paulista, Carlos Lemos 
destas alcovas é muito próxima da dimensão dos dormitórios de empregadas nos apartamentos dos dias de hoje, até a condição de ventilação é parecida.

Neste caso temos uma área destinada a circulação, coisa pouco comum, e inserida na parte íntima da casa. Salienta-se a preocupação com a chamada sala de jantar de dimensões avantajadas era a sala aonde tudo acontecia no que se referia a vida doméstica, segundo LEMOS(1999).

Tabela 26- Fazenda Tatu

Fonte : autor

\begin{tabular}{l|c|c|c}
\hline COMPARTIMENTOS & DIMENSÕES & ÁREA $\left(\mathrm{m}^{2}\right)$ & $\%$ \\
\hline ALCOVAS DE HOSPEDES & $2,00 \times 2,00$ & $4,00 \times 6=24,00$ & 5 \\
\hline SALA & $6,00 \times 6,50$ & $22,00 \times 3=66,00$ & 13,86 \\
\hline ALCOVAS (X8) & $2,00 \times 2,00$ & $4,00 \times 8=32,00$ & 6,72 \\
\hline SALA DE JANTAR & $6,00 \times 16,00$ & 96,00 & 20,16 \\
\hline DEPENDÊNCIAS - & $5,20 \times 6,30$ & 32,76 & 6,88 \\
\hline CIRCULAÇÃO & $3,00 \times 6,00$ & 18,00 & 4,83 \\
\hline
\end{tabular}

\section{O Brasil do Século XIX, o Brasil Independente}

A importância dos móveis e equipamentos nas habitações paulistas, definindo espaços (dimensões) e indicando usos só aconteceu de forma mais significativa, ou pelo menos na forma como conhecemos hoje, após a injeção do dinheiro do café, até então são citados por Lemos ${ }^{21}$ em inventários e retirados de gravuras, apenas as cadeiras duras de encosto reto, cabides nas paredes e caixas para guardar coisas, a casa colonial só tinha o estritamente necessário.

Com o advento da lavoura de café, as influencias da revolução industrial vieram de forma acelerada, diferente do Rio de Janeiro, capital do império, que em 1864 inaugurou o Palácio do Catete já completamente livre da moda neoclássica trazida pela missão francesa.

Em São Paulo, as alterações na arquitetura residencial foram mais evidentes, criando um confronto entre o velho e novo o caipira e o erudito e foi

${ }^{21}$ Lemos, Carlos Alberto 1999- A Casa Paulista: história das moradias anteriores ao ecletismo trazido pelo café- EDUSP. São Paulo. 
trazido através e pelos filhos de fazendeiros de café que foram estudar fora. As instalações sanitárias, não citadas até o presente momento, dentro do corpo da casa só vieram a acontecer após a $1^{\mathrm{a}}$ guerra mundial, a bacia sanitária foi inventada por americanos e foram eles os primeiros a levá-las para dentro da casa. Até então, a higiene pessoal é feita dentro do espaço dos dormitórios e as necessidades fisiológicas na "casinha" fora do corpo principal da casa, no quintal.Temos notícia de salas de banho nas casas de fazendas aproximadamente em 1870, na forma de balneário, que centralizavam as instalações hidráulicas, ainda fora da casa como construção anexa. Com o tempo a sala de banho saiu do quintal e dos dormitórios para ter compartimento próprio.

\section{O Ecletismo e a Revolução Industrial}

O ecletismo (1880 até 1914) veio junto com a revolução industrial e concomitantemente a sua ocorrência na Europa, fato pouco usual , normalmente as novidades chegavam ao Brasil com pelo menos 50 anos de atraso. Encontrando espaço obteve um desenvolvimento livre, passando até a utilizar mais de 1 estilo na mesma construção, este fato era novo por aqui, pois a casa colonial brasileira de arquitetura chã ${ }^{22}$ tinha o mesmo estilo para o rico e para o pobre, só variava de tamanho, nas dimensões e quantidades de compartimentos.

Começam a chegar novos materiais e imigrantes, também trouxeram o seu saber fazer, os estilos de seus paises, com isto pudemos verificar uma variação nas casas de forma mais qualitativa e não apenas quantitativa, aonde os ricos usavam materiais inacessíveis aos pobres, tudo era importado, estes materiais vinham como lastro nos navios que levavam o açúcar, o café e até a borracha.

É importante ressaltar que o mobiliário que foi importado e inicialmente colocado no espaço já existente das casas,

22 LEMOS, Carlos 1999 passim. 
"um morar à francesa incorporando os elementos da casa paulistana ${ }^{23 "}$ (que era sem corredores), a modernidade veio de dentro para fora, só depois do advento do café é que a construção das casas veio a incorporar os novos equipamentos e mobiliário.

O morar a francesa pressupunha a divisão da casa em três zonas distintas, a de estar e receber, a de repousar, e a de serviço, deveríamos ir de uma para outra sem passar pela terceira. ${ }^{24}$

\subsection{Iluminação Artificial}

A iluminação artificial veio alterar as atividades familiares, e assim seus hábitos e a vida social (área até então pública). A capacidade de iluminamento da vela era muito pequena (só servia para que se tivesse noção de espaço), os horários passaram a ser mais elásticos e possibilitando atividades noturnas, como por exemplo, receber após as 18:00 horas.

O piano se popularizou após 1850 e a caixa de música foi aperfeiçoada, os móveis; como armários espelhos e mesas retráteis, móveis "Thonet ", o bidê de latão, foram importados. Enfim as atividades dentro do espaço residencial foram alteradas e provocaram mudanças também nos programas de necessidades. A privacidade pode ser considerada uma das funções mais importantes da casa,

A zona da casa privada, pertencia as atividades desenvolvidas pelas mulheres como as funções de mãe, educadora, reprodutora, consumidora, enquanto para o homem ficava o setor público (aqui inicia-se o setor social substituindo o genérico público), o trabalho, a reprodução, a razão, a ciência, a cultura, a política e a atividades extra muros. Estas funções e atividades eram expressas nos seguinte ambientes; mulher; a sala da senhora, entre a zona de serviços e a sala de jantar e de visitas, ou seja um estar informal, lembrando-nos das casas gregas aonde tínhamos o Oecus e da casa islâmica aonde a mulher tinha uma sala (iwan) para receber pessoas próximas. Ao homem estavam

\footnotetext{
${ }^{23}$ HOMEM, Maria Cecília 1992 -O Palacete Paulistano e outras formas urbanas de morar da elite cafeeira tese de doutorado FAU USP

${ }^{24}$ passim 23.
} 
relacionados o gabinete, com entrada independente, o fumoir o bilhar e a biblioteca.

\title{
3.2.Industrialização de Alimentos como Modificadora de Dimensões
}

A casa passa de unidade subsistência, "atendimento das necessidades" ${ }^{\prime 25}$, para unidade de; consumo, higiene, publicidade e estudo para mulher, com a função de proteger o que é íntimo da esfera social.

As industrias Francisco Matarazzo, iniciaram suas atividades em 1882 e vieram a atender deficiências antigas das cozinhas. Desde os tempos de colônia as famílias estavam acostumadas a beneficiar os gêneros alimentícios em casa, o que exigia grandes áreas construídas nas zonas de serviço.

\begin{abstract}
"A casa que se prezasse, possuía vários tipos de pilão......Enormes tachos e caldeirões.......Jiraus para conservação do toicinho, da carne de sol, do milho...Grandes prateleiras para os potes de água ........As gamelas, as masseiras para o pão semanal......... fogão da cozinha "suja " no fundo do quintal e o fogão da cozinha limpa próximo a sala de jantar." 26
\end{abstract}

\section{Os Palacetes Paulistanos (1867 a 1918)}

O conceito de palacete, a sua implantação e distribuição vieram da influencia da burguesia francesa, através de viagens realizadas a França subsidiadas pela economia do café. Antes as formas de morar paulistanas obedeciam a um tipo de distribuição feita no sentido frente trás, como mostram os exemplos:

Fig. I 72 Planta de distribuição linear antes do café

Fonte :Casas Paulistas, LEMOS Carlos pág. 28

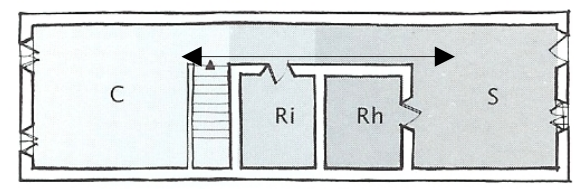

\footnotetext{
${ }^{25}$ HANNAH Arendt, 1981 pág. 73 A Condição Humana.

${ }^{26}$ LEMOS, Carlos 1993 Transformações do espaço habitacional ocorridas na arquitetura brasileira do século XIX-Anais do Museu Paulista .
} 


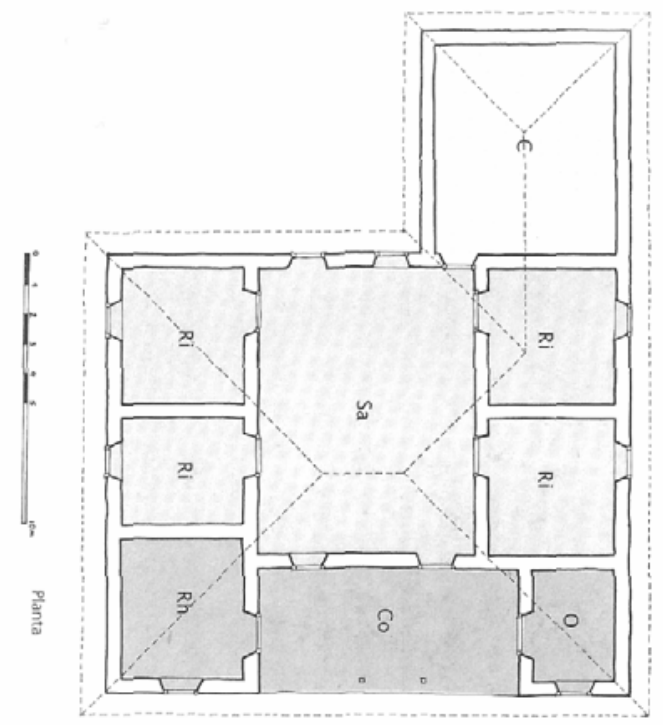

Fig. I 73 Planta Sítio do Calú - Embu

Casa Paulista Rural antes do Café

Fonte: Casas Paulistas, Carlos Lemos ,pág. 48

A figura I 72 nos mostra que a privacidade é questionável, pois os empregados e moradores passavam por todos os cômodos, esta disposição, pode ser considerada uma influencia medieval, entre outras, trazida de Portugal, quando as cidades rodeadas de muros e tinham lotes estreitos, segundo Lemos.

Um exemplo notório de palacete paulistano é a casa de D. Veridiana, que veio a inovar na distribuição doa ambientes com a cozinha no porão, a tecnologia para o monta cargas e para a coifa de exaustão foi indispensável, chegando a ser um exagero da importação da tecnologia, já que a tradição centenária da cozinha próxima da sala, com a figura da dona da casa (por mais rica que fosse), circulando entre os dois ambientes e em contato direto com as empregadas, fazia parte de um conjunto de hábitos arraigados no modo de vida da família brasileira, fazendo com que esta distribuição logo fosse abandonada.

A importância do trabalho das empregadas domésticas nas habitações de classe média e alta, até os dias de hoje, faz parte da nossa cultura, estando até hoje incluídas as dependências de serviço no programa de necessidades de nossas habitações. As próximas gerações poderão visualizar 
esta realidade através, não só pelos programas das habitações como também pelas tramas de "telenovelas", que tão bem retratam esta peculiaridade.

O vestíbulo, chamado de hall após a $1^{\mathrm{a}}$ grande guerra, veio para ficar, garantindo a interdependência de cada zona da habitação, até hoje é compartimento indispensável nas casas portuguesas, mesmo nas chamadas sociais (Habitações de interesse social) ${ }^{27}$.

Com a análise das dimensões constantes em um levantamento do escritório de Ramos de Azevedo, sobre o palacete de Rafael Tobias de Aguiar Paes de Barros, Barão de Piracicaba II, constantes no trabalho de Maria Cecília Homem $^{28}$, pode-se constatar a transição da casa da fazenda para os Palacetes já com a influencia dos conhecimentos advindos com a economia do café.

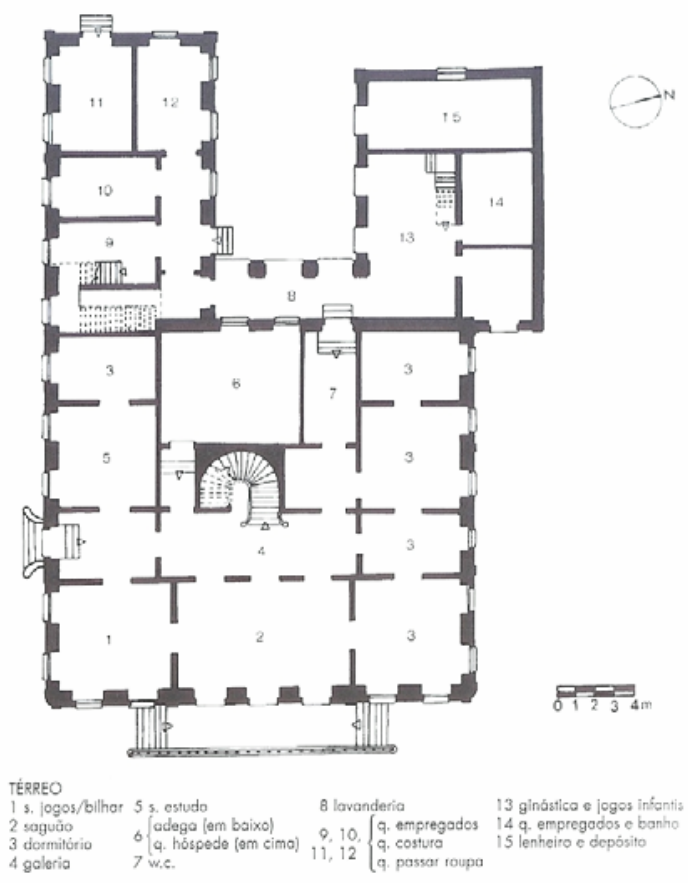

Fig. I 74 Planta Térreo- Palacete Barão de Piracicaba II Fonte: Pág.86, O Palacete Paulistano, HOMEM, Maria Cecília,

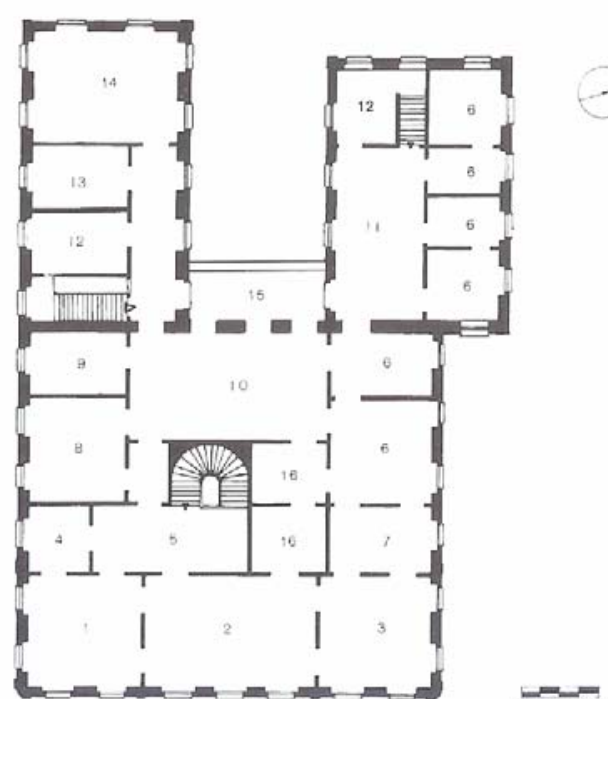

Fig. I 75 Planta $1^{\circ}$ Pavimento- Palacete Barão de Piracicaba II

Fonte: O Palacete Paulistano, HOMEM, Maria Cecília,Pág.86

\footnotetext{
${ }^{27}$ trabalho apresentado pelo Prof. PEDRO, João Branco em intercambio realizado através de visita na FAU USP em 09/2005.
} 
Tabela 27 - Palacete Barão de Piracicaba II- Pav. térreo Fonte:autor

1. Térreo- área útil ( $\mathrm{sem}$ as paredes) $=580,00 \mathrm{~m}^{2}=100 \%$

\begin{tabular}{|c|c|c|c|c|c|}
\hline \multirow{23}{*}{ } & SIGLA & COMPARTIMENTO & DIMENSÕES(m) & ÁREA $\left(m^{2}\right)$ & $\%$ \\
\hline & 1 & S. de Jogos/ Bilhar & $5.90 \times 5.60$ & 33.04 & 5,70 \\
\hline & 2 & Saguão & $9.10 \times 5.50$ & 50.05 & 8,63 \\
\hline & 3 & Dormitório-1- & $5.20 \times 5.60$ & 29.12 & 5,02 \\
\hline & 3 & Dormitório-2- & $5.20 \times 3.20$ & 16.64 & 2,87 \\
\hline & 3 & Dormitório-3- & $5.20 \times 5.35$ & 27,42 & 4,72 \\
\hline & 3 & Dormitório-4- & $5.20 \times 3.60$ & 16.76 & 2,89 \\
\hline & 3 & Dormitório-5- & $5.08 \times 3.30$ & 16,76 & 2,89 \\
\hline & 4 & Galeria & $10.30 \times 3.30$ & 31.08 & 5,35 \\
\hline & 5 & S. de Estudos & $5.10 \times 5.30$ & 27.03 & 4,66 \\
\hline & 6 & Hospedes/ Adega & $7.30 \times 5.90$ & 43,07 & 7,42 \\
\hline & 7 & Banheiro & $2.70 \times 5.90$ & 15.93 & 2,74 \\
\hline & 8 & Lavanderia/ A serviço & $7.50 \times 2.15$ & 16.12 & 2,78 \\
\hline & 9 & Dep de Servico & $2.10 \times 3.60$ & 760 & 1.31 \\
\hline & & & excluída a escada & & \\
\hline & 10 & Quarto de Costura & $3.10 \times 5.00$ & 15.50 & 2,67 \\
\hline & 11 & Quarto de Passar Roupa & $3.85 \times 5.50$ & 21,17 & 3,65 \\
\hline & 12 & Dormitório de Serviço & $3.35 \times 5.50$ & 18.42 & 3,17 \\
\hline & 13 & Ginástica / Jogos Infantis & $8.66 \times 3.65$ & 31.61 & 5,37 \\
\hline & 14 & Quarto de Empregados & $3.60 \times 4.85$ & 17.46 & 3,01 \\
\hline & 15 & Lenheiro / Depósito & $3.60 \times 8.60$ & 30,96 & 5,34 \\
\hline & 16 & Banheiro serviço & $3.60 \times 3.90$ & 14,04 & 2,42 \\
\hline & & Circulação & & 59,30 & 10.22 \\
\hline
\end{tabular}

\section{Planta $1^{\circ}$ Pavimento}

Tabela 28 - Palacete Barão de Piracicaba II- $1^{\circ} \mathrm{Pavimento}$ Fonte: autor

\begin{tabular}{|c|c|c|c|c|}
\hline \multirow{3}{*}{$*$} & SIGLA & COMPARTIMENTO & DIMENSÕES(m) & ÀREA $\left(\mathrm{m}^{2}\right)$ \\
\cline { 2 - 5 } & 1 & Salão Azul & $5.95 \times 5.80$ & 34.51 \\
\cline { 2 - 5 } & 2 & Salão vermelho & $9.00 \times 5.80$ & 52.20 \\
\cline { 2 - 5 } & 3 & Escritório & $5.20 \times 5.60$ & 29.12 \\
\cline { 2 - 5 } & 4 & Sala de Piano & $3.20 \times 3.50$ & 11.20 \\
\hline
\end{tabular}

\footnotetext{
${ }^{28}$ Ibdem 7.
} 


\begin{tabular}{|c|c|c|c|}
\hline \multicolumn{4}{|c|}{ Continuação Tabela 28} \\
\hline 5 & Hall & $8.20 \times 3.50$ & 28.70 \\
\hline 6 & Dormitório -1- & $5.35 \times 5.40$ & 28.89 \\
\hline 6 & Dormitório -2- & $5.30 \times 3.20$ & 16.96 \\
\hline 6 & Dormitório -3- & $3.80 \times 3.70$ & 14.06 \\
\hline 6 & Dormitório -4- & $3.80 \times 2.60$ & 9.88 \\
\hline 6 & Dormitório -5- & $3.80 \times 2.40$ & 9.12 \\
\hline 6 & Dormitório -6- & $3.80 \times 3.90$ & 14.82 \\
\hline 7 & Sala de Vestir & $5.35 \times 3.50$ & 18.72 \\
\hline 8 & S. da Senhora - Verde & $5.00 \times 5.50$ & 27.50 \\
\hline 9 & Copa & $5.00 \times 3.20$ & 16.00 \\
\hline 10 & Sala de Jantar & $10.50 \times 5.60$ & 58.80 \\
\hline 11 & Sala das Crianças & $4.60 \times 9.00$ & 41.40 \\
\hline 12 & Banheiro & $5.00 \times 3.20$ & 16.00 \\
\hline 13 & Despensa & $5.00 \times 3.30$ & 16.50 \\
\hline 14 & Cozinha & $7.60 \times 5.85$ & 44.46 \\
\hline 15 & Terraço & $7.20 \times 2.60$ & 18.72 \\
\hline 16 & Alcova 1 & $3.80 \times 3.50$ & 13.30 \\
\hline 16 & Alcova 2 & $\begin{array}{c}3.80 \times 3.10 \\
\text { próxima S. Jantar }\end{array}$ & 11.78 \\
\hline
\end{tabular}

Nota: Estas dimensões foram retiradas dos desenhos de acordo com a escala gráfica.

Os dormitórios e a circulação, assim como as espessas paredes, ainda guardavam características das casas mais antigas, porém, acrescidas de inovações como os recuos de frente e laterais e a separação das entradas de serviço e social, ficando nítida a área destinada a circulação nobre o " Vestíbulo", a área destinada a circulação ultrapassa os 15\% da área líquida do pavimento, sem considerar a interligação entre os compartimentos, estes vãos como víamos nas casas de fazenda e também nos apartamentos parisienses da $2^{\mathrm{a}}$ metade do século XIX (Apartamento a rua Theodore de Banville ${ }^{29}$ )retratam a fase de transição destas construções.

O Barão construiu este palacete em 1877. A novidade na distribuição ficou por conta da disposição dos dormitórios com janelas para a face nordeste da edificação Verifica-se apenas 2 alcovas de dimensões reduzidas $3.80 \times 3.50$, comparadas aos dormitórios, como por exemplo o dormitório-3 do pavimento térreo com 5.20 x 5.35m e a introdução dos quartos de vestir, que acredita-se, seriam os dormitórios menores, dispostos ao lado dos de maior dimensão.

${ }^{29}$ Schoenauer, Norbert $-6,000$ Years of Housing, 
O restante da distribuição reproduzia o esquema tradicional do sobrado, com a sala para frente e a cozinha para os fundos em um anexo. A decoração é citada como profusa por Maria Cecília, aonde os salões eram denominados por suas cores predominantes e ricamente mobiliados com móveis franceses e importados pela Casa Garraux É importante ressaltar a dimensão da sala de jantar, que abrigava uma mesa de 6,00m de comprimento e utilizando os espaços de atividade definidos por Boueri ${ }^{30}$ podemos averiguar a ocupação dos espaços em função do seu dimensionamento.

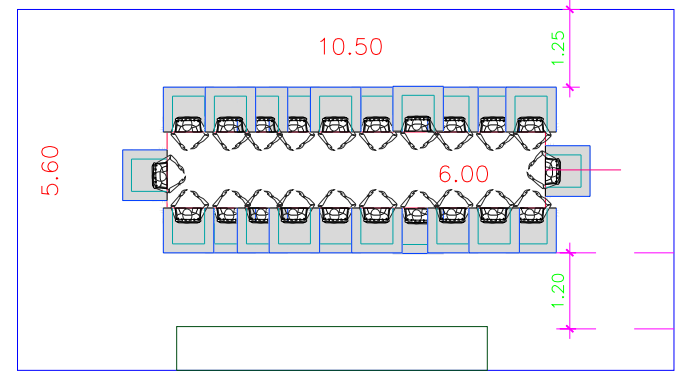

Fig.I 79 -Detalhe Planta Sala de Jantar

Palacete Barão de Piracicaba II

(Composição autor, com os Espaços de Atividades BOUERI (2004)

A área total de cada pavimento, com paredes, era de aproximadamente $760,00 \mathrm{~m}^{2}$ e a área líquida, ou seja sem as paredes do térreo era aproximadamente $580,00 \mathrm{~m}^{2}$.

\section{A Modernidade em São Paulo}

A modernidade em São Paulo década de 20, morar após a $1^{\text {a }}$ Guerra , o estilo poderia ser chamado de neo colonial, segundo Lemos, uma arquitetura sem nome definida com o americana, trazida pela companhia city que aqui chegou em 1912. O que altera na distribuição dos ambientes; o antigo vestíbulo agora chama hall, com papel de distribuição e circulação, a copa ficou definida e, era um a ambiente de passagem da comida para a sala de jantar, os recuos da construção ficam estabelecidos, a edícula que antes existia como cocheira, 
galinheiro agora tem o uso de dependências de empregados, que antes eram no sótão os mais categorizados ${ }^{31}$ ou no porão os menos.Não temos apenas os palacetes, em São Paulo temos também os sobrados geminados em 1920, frutos da sobra de capital do café empregado em imóveis para locação.

\subsection{Queda do café}

Com a queda do café os fazendeiros deixam de investir em imóveis e assim é criado um déficit habitacional agravado pela guerra de 39, e culminando com a lei do inquilinato feita por Getúlio. A imigração de estrangeiros acabou, mas teve início a imigração interna, a de nordestinos, a população começou a construir com as próprias mãos - autoconstrução - povo faz casa conforme seus desejos, o proletariado faz o que pode e não o que quer, pois na realidade gostaria de ter os bangalôs dos jardins.

Com o abandono dos palacetes, devido a deteriorização e conseqüente descaracterização, por escassez de mão de obra para a limpeza, manutenção e a obsolência dos materiais de construção, das instalações hidráulicas e elétricas, comprometendo a segurança, surgiram os cortiços, a promiscuidade e socialização das áreas comuns.

\section{Verticalização}

A verticalização chegou em São Paulo também, na década de 20 e era voltada para classe média, a classe mais alta achava que apartamentos eram cortiços disfarçados. O mesmo aconteceu na Inglaterra dos final do século XIX, a sociedade britânica preferia uma casa em rua tranqüila, ao tráfego intenso das zonas mais centrais, a situação foi agravada pela proliferação de doexnças nas zonas centrais.

\footnotetext{
${ }^{30}$ Prof. Dr.BOUERI, Jose Jorge, A Contribuição da Ergonomia na Formação do Arquiteto, tese de livre docência FAU USP, 2004.

${ }^{31}$ Categorizados eram os mordomos e as preceptoras.
} 
A construção de edifícios foi concentrada na área central, perto de tudo, devido a deficiência dos transportes coletivos, (bonde 1900, ônibus 1924). Após a criação da usina de Volta Redonda e produção própria de aço, a verticalização tomou impulso maior com a utilização do concreto armado.

Com o advento do rádio, tivemos o inicio de um lazer masculino dentro da casa, inicialmente individual e posteriormente sendo ouvido por toda a família. A localização do rádio poderia ser na sala de jantar, na copa ou na cozinha.É importante assinalar as atividades de lazer e seus respectivos ambientes dentro das casas, pois segundo Witold, os ambientes generosos que se comunicam entre si dificultam a utilização de equipamentos de entretenimento doméstico

"O que se precisa é de muito mais cômodos pequenos alguns não precisam ser maiores do que alcovas para se adequar a ampla variedade de atividades de lazer da casa moderna." 32

A televisão foi uma pá de cal, no convívio familiar, segundo Lemos, anulou a sala de visitas, agora utilizada realmente pela família.Os móveis foram sendo alterados, sofás mais confortáveis, não mais cadeiras de palhinha e até a postura das pessoas que tinham que estar vendo a tv, enquanto o rádio podia ser escutado de longe sem necessidade de espaço, a tv era diferente, era uma a atividade que precisava de espaço, inicialmente aconteceu o mesmo que outrora com os novos móveis, que vieram para cá no final do séc XVIII e foram colocados nos espaços existentes. O modo de produzir programas de necessidades foi alterado vagarosamente.As televisões foram para as salas de estar interferindo nas atividades sociais.

Os arquitetos modernos, em busca da continuidade espacial, propuseram uma alteração nesta conformação de casas com vestíbulo, sala de estar e jantar, eliminando a separação entre estes ambientes.Temos exemplos em Victor Dubugrás, casas sem vestíbulos e Rino Levi com escadas saindo do living.Com a influencia dos arquitetos modernos a edícula foi sumindo ficando

${ }^{32}$ RYBCZYNSKI,Witold, pág. 2272002 Casa Pequena História de Uma Idéia .Ed. Record 
apenas para garagem e com o passar do tempo também o carro veio para frente da casa.

Segundo Lemos, a televisão associada ao computador vieram tumultuar a organização das habitações.Cada pessoa da família busca um lazer diferenciado e, sobretudo os jovens universitários querem o som e computadores pessoais, fazendo com que seus dormitórios tenham sobreposição de funções.Seguindo a mesma linha de raciocínio deste professor a superposição de funções é que induz a programas distintos de apartamentos, concluindo com uma maior compartimentação, e diminuindo a dimensão dos compartimentos esta é "o quadro do Morar Moderno".

Faremos uma relação de obras com suas dimensões e arranjos:

\subsection{Edifício Ésther 1935}

Local: Av. Ipiranga esq. Rua Sete de Abril

Autores - Eng. Civis Arquitetos - Álvaro Vital Brasil e Adhemar Marinho

Segundo os autores ${ }^{33}$ trata-se do primeiro prédio de grande porte, construído em São Paulo com estrutura independente.Este edifício abrigava apartamentos de diferentes áreas, desde 1 compartimento chamado de sala+ banheiro e varanda, até apartamentos de 4 dormitórios nos últimos andares a área do pavimento é 753,73m² .Edifício Esther planta do 9º pavimentos 1938.

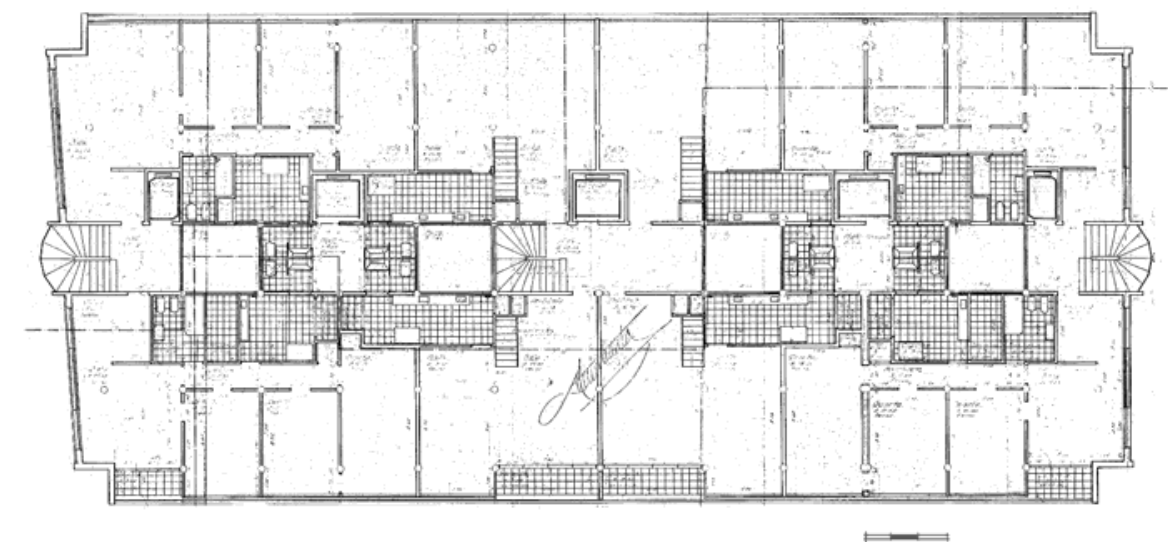

Fig.I 77- Planta 9 Pavimento Edifício Esther- arquivo FAU USP 


\subsection{Edifício Sra. Germanie Buchard ${ }^{34}$}

\section{Local: Praça Buenos Aires}

Autor: Severo Villares \& Cia Escritório técnico Ramos de Azevedo

Este projeto datado de 1939, é importante para o presente estudo, a medida que apresenta uma transição dos palacetes apresentados anteriormente neste capítulo, para a verticalização com as mesmas solicitações de programa de ambientes.

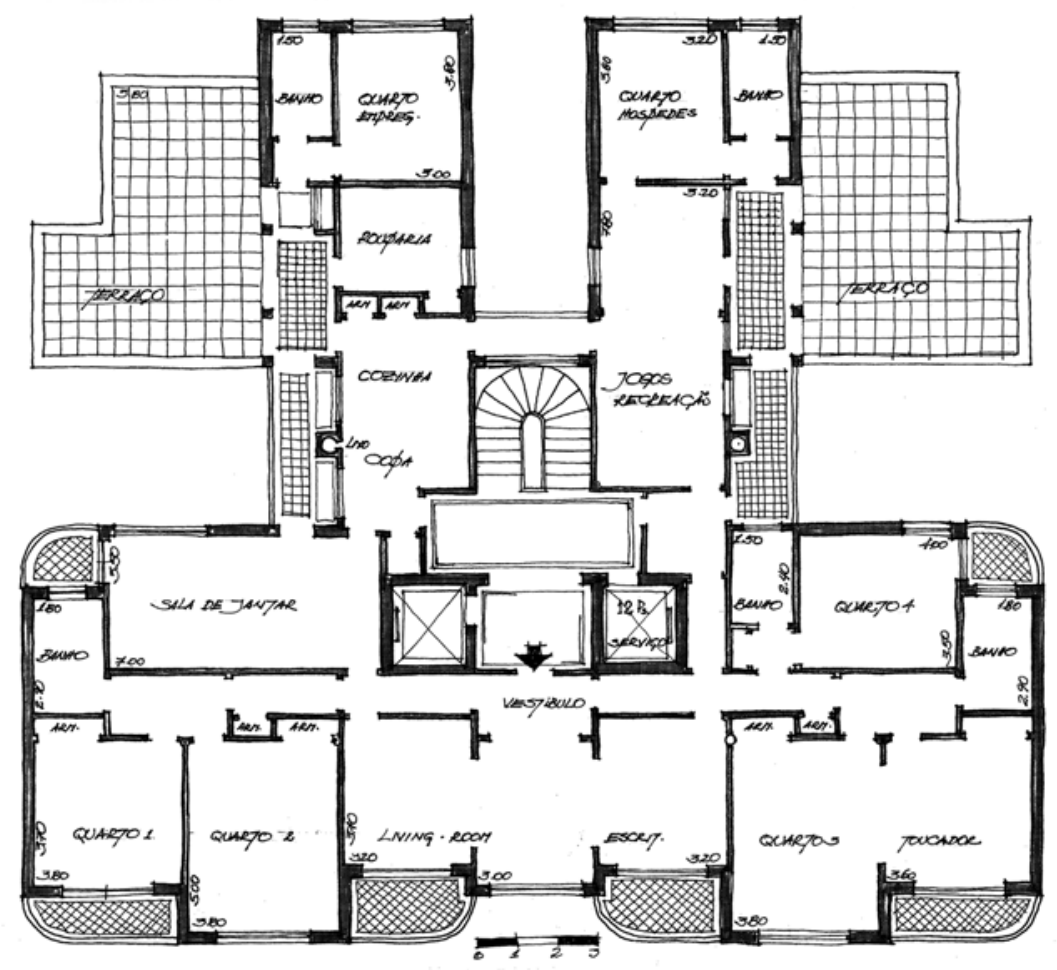

Fig. I 78 Edifício Sra. Germanie Buchard - Cobertura

A planta do $10^{\circ}$ pavimento (fig 78), a cobertura, forma um único apartamento possuindo disposição semelhante a dos Palacetes Paulistanos, porém com dimensões reduzidas. Este apartamento tem como programa; sala de estar (living room), escritório conjugado a sala de estar, sala de jantar, 4 dormitórios e mais uma suíte (dormitório com banheiro acoplado), copa, cozinha,

\footnotetext{
${ }^{33}$ - XAVIER, Alberto;LEMOS, Carlos Alberto;CORONA Eduardo- 1983 pag. 4 “ Arquitetura Moderna Paulista"

${ }^{34}$ P ES19/728 - 1AD" -1939 - Arquivo desenhos FAU
} 
salão de jogos/recreação, rouparia, dormitório de empregados com banheiro, que por sua vez estavam contíguos a um terraço de serviço e mais um $6^{\circ}$ dormitório para hóspedes com banheiro, este último localizado de tal forma que chega a lembrar os dormitórios de hóspedes das casas da época colonial, pois estava ligado ao hall de entrada, sem incomodar a família, e o seu acesso era feito através de uma varanda, um espaço aberto e coberto dando para um terraço descoberto. $\mathrm{O}$ pavimento tipo do edifício era composto de 4 unidades de

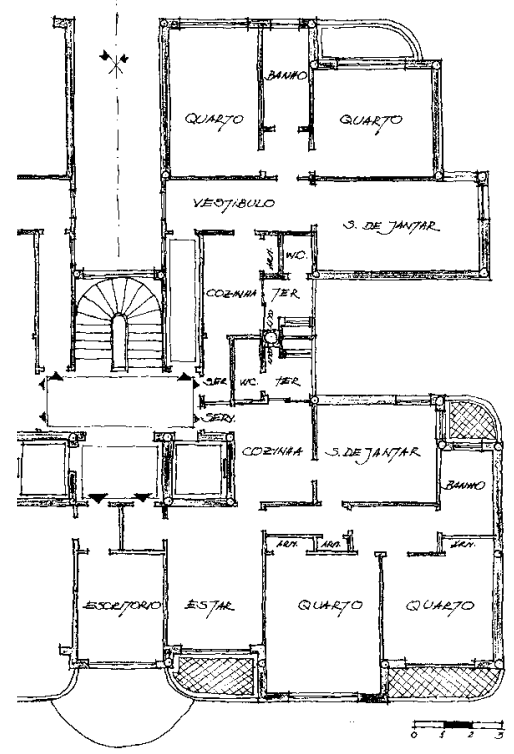
2 dormitórios, como mostra a fig. 79, com o seguinte programa de ambientes; sala de estar, varanda, sala de jantar, cozinha, terraço de serviço, banheiro de empregada e dependências de serviços.

Cabe ressaltar a pequena área social e o tamanho avantajado dos dormitórios para os dias de hoje, porém, pequeno se com parados aos do Palacete do Barão de Piracicaba, apesar da distribuição da cobertura, seguir um programa próximo.

Fig. I 79 Edifício Sra. Germanie Buchard Meio Pavimento Tipo Fonte desenho do autor sobre cópia do arquivo FAU USP

\subsection{Edifício Louveira 1946}

Local: Praça Vilaboim Autor: Artigas, João Vilanova e Carlos Cascaldi

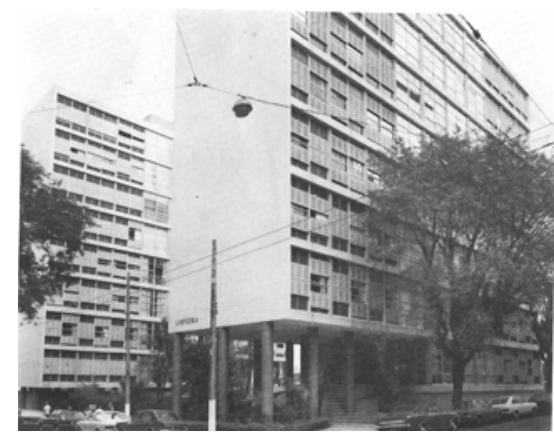

Fig.l 80 Foto Edifício Louveira

Fonte: pág. 16 "'Arquitetura Moderna Paulista" 
Solução inovadora para terreno de esquina, até então em forma de L, e aqui 2 blocos paralelos. O distanciamento entre os blocos de $20 \mathrm{~m}$ atendia o numero de horas de insolação no dia mais curto do ano.(exigidas pelo código de obras, em vigor na época).

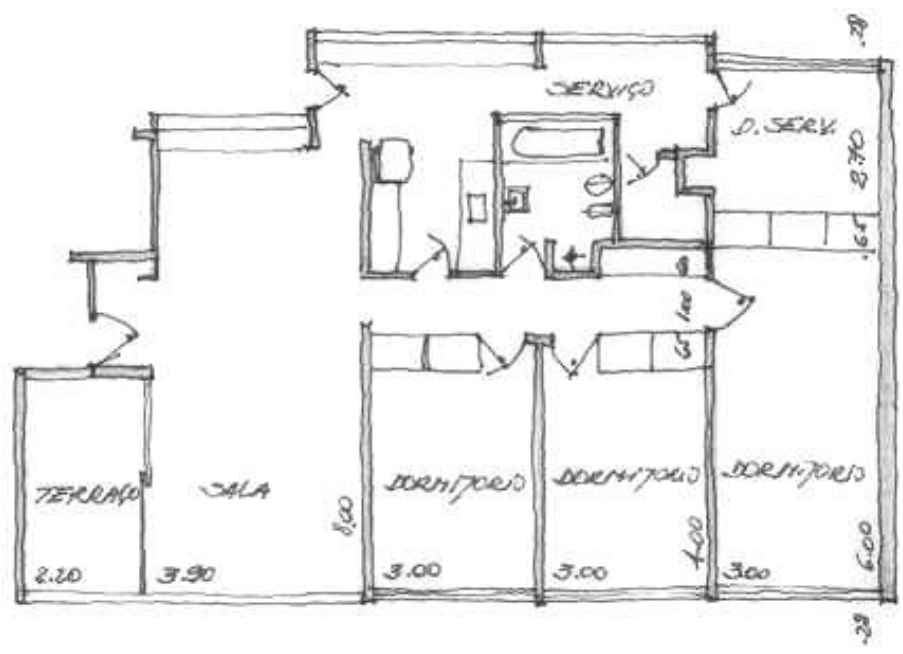

Fig. I 81 Edifício Louveira Planta apartamento tipo Fonte: desenho do autor sobre arquivo digital FAU USP

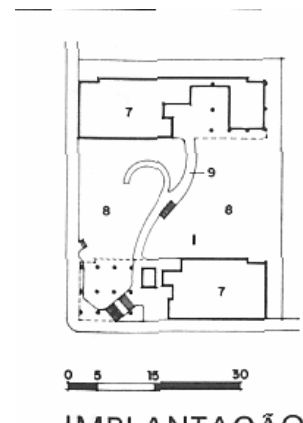

IMPLANTAÇÃO
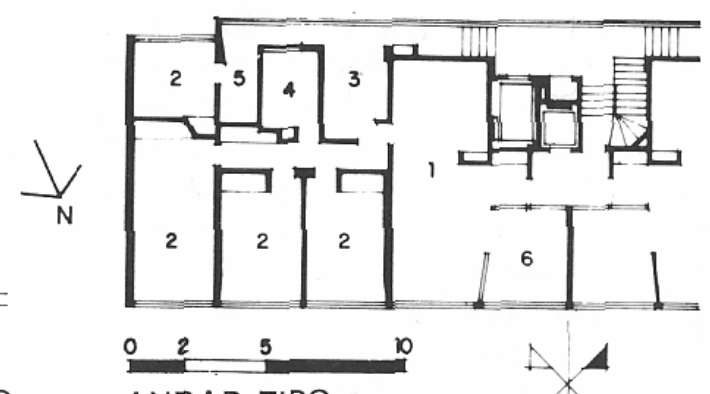

ANDAR TIPO
1. Sala

2. Quarto

3. Cozinha

4. Banheiro

5. Serviços

6. Terraço

7. Edificação

8. Jardim

9. Acessos

Fig.I 82 Edifício Louveira Implantação Fonte:pág. 16 "Arquitetura Moderna Paulista" 


\subsection{Edifício Prudência 1944- 1948}

Local: Av. Higienópolis

Autor: Rino Levi

"Na década de 40 tem início a construção de prédios de alto padrão de conforto ${ }^{36 " .}$.

O edifício Prudência foi um marco de inovação e conforto para sua época, não só pelas dimensões como também pela estrutura independente que possibilita a flexibilização dos espaços e uma variação grande de plantas, comportando reformas e atendendo a diversos ciclos da vida familiar, até os dias atuais.As instalações de ar condicionado central e de água quente, também foram inovadoras para época.

O térreo em pilots, os jardim e painéis de Burle Marx e a estrutura independente permitem uma comparação com projeto de Jorge Machado Moreira, 1946, na cidade do Rio de Janeiro, que também teve térreo em pilots, jardins de Burle Marx, estrutura independente e 4apartamentos por andar (característicos desta época),porém, tem como maior diferença a "dimensão dos apartamentos".

Edifício Prudência - 450,00m² de área privativa e Edifício Antonio Ceppas $170,00 \mathrm{~m}^{2}$.

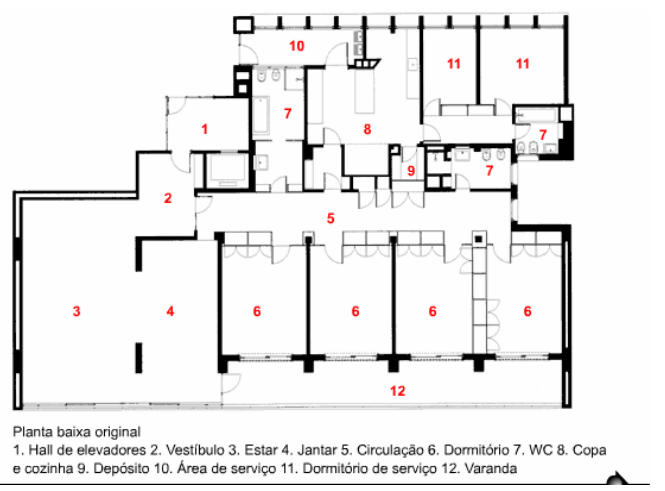

Fig.I 82 Edifício Prudência Planta original apartamento tipo Fonte:http://www.arcoweb.com.br/arquitetura/ arquitetura344.asp\#

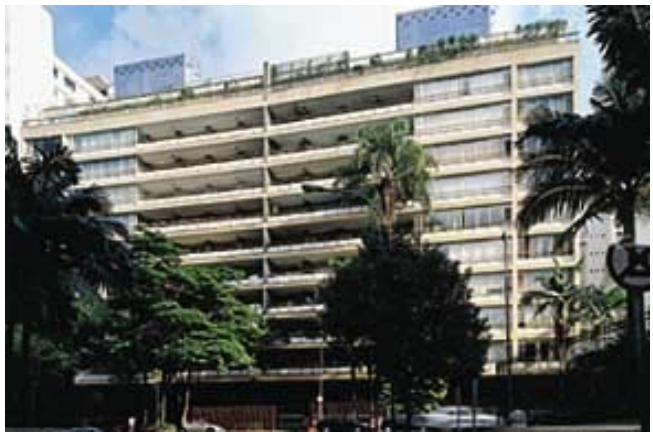

Fig.l 83

Edifício Prudência - Foto

http://www.arcoweb.com.br/arquitetura/arquitetura344.asp\# ${ }^{36}$ XAVIER, Alberto;LEMOS, Carlos Alberto;CORONA Eduardo pág. 16 "Arquitetura Moderna
Paulista" 


\subsection{Apartamento Wiliam Malluf - 1962}

Local : Rua Maranhão

Autor: Artigas, João Vilanova

Esta planta é a que mais se assemelha aos projetos de 4 dormitórios atuais, porém ainda sem as famosas suítes que caracterizam os apartamentos de 4 dormitórios do século XXI.

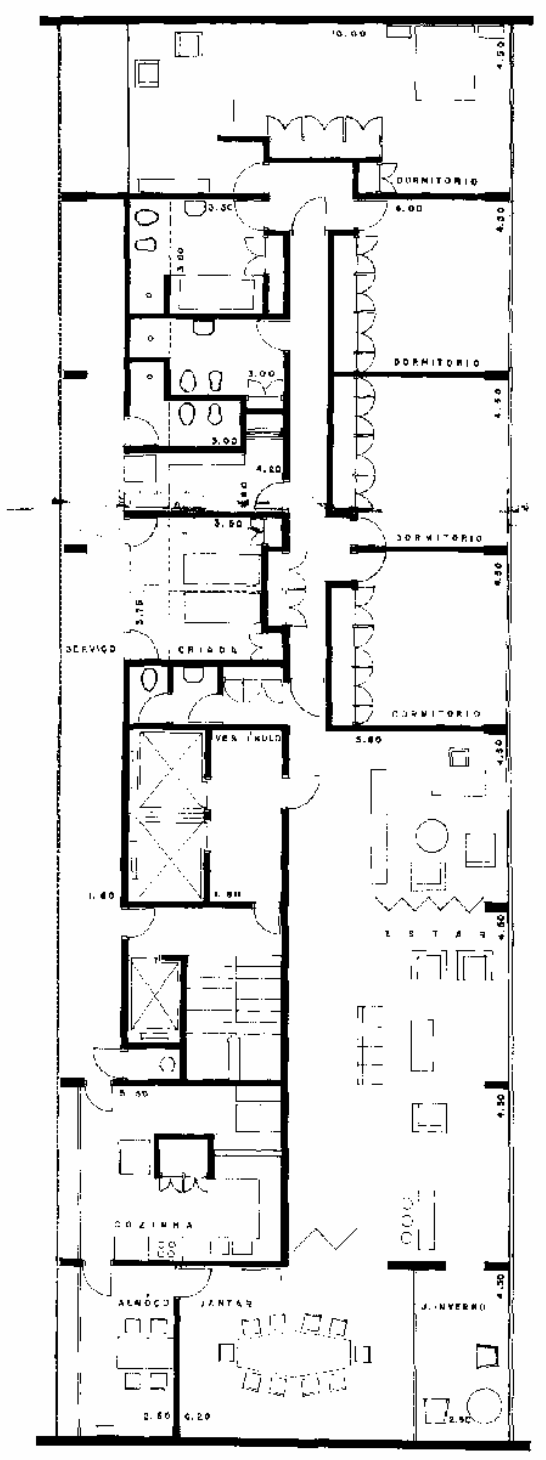

Fig. I 84 Apartamento William Malluf, Autor: Artigas, João Vilanova

Rua Maranhão Arquivo FAU USP 


\section{Síntese do Capítulo}

"Poucos hoje não partilham a sensação de viver em tempo de grandes mudanças, de profundas mutações, em quase todas as disciplinas. No campo da arquitetura (as mudanças) assumiram uma importância e uma profundidade que sugere o início de uma nova época. Os sinais destes novos tempos se encontram espalhados em todos os lugares. Assim, quisemos reuni-los para formar um panorama mundial sob o conceito das metamorfoses."- FOSTER, Kurt W. ${ }^{1}$. quando propôs o tema da Bienal de Arquitetura de Veneza, em 2005 - Metamorfose-.

Porém, a presente pesquisa nos mostra, uma outra face da arquitetura, quando faz um contraponto do homem com suas necessidades primárias. O dimensionamento de determinados compartimentos das habitações, objeto de estudo desta dissertação, não sofreu mudanças significativas, apesar das mudanças dos hábitos e costumes. Fazendo-se uma comparação através da dimensão dos dormitórios, encontradas temos:

- Os dormitórios da casa 54 de Monjero-Daro de 3000 Ac. Possuíam 4,00×5,00m (maior ambiente da área íntima), segundo SCHOENAUER.

- Os dormitórios da Casa de Muitas Cores na Grécia, de 400 a 500 anos da nossa era, possuíam aproximadamente 4,50x4,50m segundo SCHOENAUER.

- O dormitório da Turmanhaus (casa tipo torre), construção da Alta Idade Média, possuía as mesmas dimensões da casa grega. segundo SCHOENAUER.

- O dormitório de hóspedes da Casa Paulista do séc. XVII e XVIII, também possuíam 4,00 x 4,00m, segundo LEMOS.

- Os dormitórios do edifício Esther 1935, medem 3,00x 4,65m.

- Os dormitórios do Edifício Louveira de 1946 - medem 3,00 x 4,65m.

${ }^{1}$ mostra de arquitetura

da Bienal de Veneza - uma reflexão sobre como o hoje leva o amanhã, SETEMBRO 2005.www.piniweb.com.br, 2005. 
Estão excluídos aqui os palácios e as habitações de operários ou de interesse social.Mas quanto às habitações operárias ou de interesse social e incluindo neste conjunto a casa de trabalhadores no Egito, nota-se a preferência por dimensões mais reduzidas.

Este capítulo teve por finalidade um levantamento, ou uma forma de inventário do dimensionamento dos compartimentos da habitação em ordem cronológica, não só no Brasil mas também em outros países com outras culturas e outros hábitos.

\section{RESUMO DAS DIMENSÕES DOS ESPAÇOS DE REPOUSO}

\begin{tabular}{|c|c|c|c|c|}
\hline ÉPOCA & EXEMPLOS & USO / FUNÇÃO & ÁREA & ÁREA \\
\hline & & REPOUSO/ABRIGO & MAIOR & MENOR \\
\hline Temporária & OCA & abrigo / repouso & 5,00 & \\
\hline Temporária & cubeo MALOCA & repouso/ estar & 18,00 & \\
\hline Semi Perm. & MESAKIN & repouso & 9,00 & \\
\hline Permanentes & CHINESE CAVE & repouso & 20,00 & \\
\hline 3250 a 2750 aC & MOHENJO DARO & área íntima & 20,00 & \\
\hline 687 a $637 \mathrm{aC}$ & RED HOUSE ASSUR & repouso & 8,00 & \\
\hline 400 a 500 & CASA DE MUITAS CORES & repouso & 20,25 & \\
\hline 80 & POMPEIA(Palacio Panda) & repouso & 15,00 & 8,00 \\
\hline 1250 & TURMAN HAUS & repouso & 20,25 & \\
\hline $\sec$ XIII a XV & PLACA & repouso & 18,00 & \\
\hline 1727 & QUEEN'S SQUARE & repouso & 20,00 & \\
\hline $\sec X V I I$ & CADOGAN SQUARE & repouso & & \\
\hline 1879 & BYLAW HOUSE & repouso & 5,25 & 9,30 \\
\hline $\sec X I X$ & VILA SUBURBANAS & repouso & 26,10 & 25,00 \\
\hline $\sec X I X$ & APTO Theodore banville & & 25,00 & 18,53 \\
\hline 1900 a 1950 & LENCHWORTH & & 12,60 & 10,80 \\
\hline 1900 a 1950 & BANGALÔ & & 12,60 & \\
\hline 1931 & CASA PÁTIO & & 12,20 & 8,00 \\
\hline 1967 & SILVER TOWER & & 15,00 & 12,00 \\
\hline sec. XVII e XVIII & CASA VILA PAULISTA & repouso (alcovas) & 14,00 & \\
\hline 1877 & PALACETE B. PARANAPIACABA & repouso (alcovas) & 29,12 & 16,76 \\
\hline 1935 & ED. ESTHER & & 16,95 & 11,85 \\
\hline 1939 & ED. GERMANIE BUCHARD & & 19,00 & 14,06 \\
\hline 1946 & ED. LOUVEIRA & & 18,00 & 12,00 \\
\hline
\end{tabular}




\section{Capítulo II}

NIVEL MINIMO - 8/9 Utentes (A.R.: 2.50)
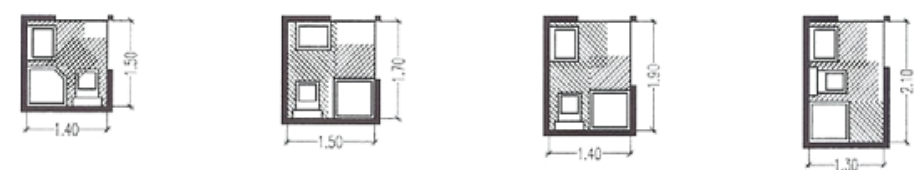

Áreo: 2.10

Area: 2.55

Areo: 2.66

Area: 2.73

Fonte : PEDRO

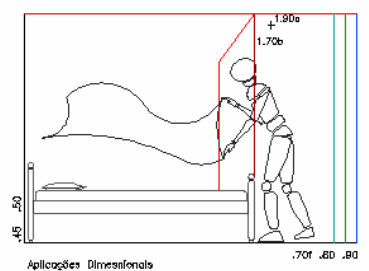

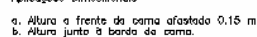

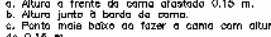

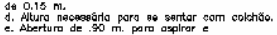

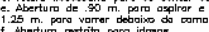

fonte: BOUERI

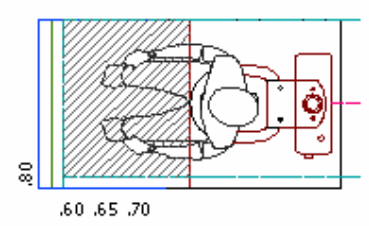

.60 .65 .70 


\section{Capítulo II}

\section{Qualidade Habitacional}

\section{Embasamento Teórico}

Após a conclusão da pesquisa "Inventário das Recomendações Dimensionais dos Espaços, Equipamentos e Mobiliário"”, surgiu o estimulo de avaliar a qualidade habitacional das plantas levantadas e a possibilidade foi reforçada com a presença do arquiteto pesquisador português do Laboratório Nacional de Engenharia Civil, PEDRO, João Branco².

Para o estudo deste capítulo, o presente trabalho teve a co-orientação de PEDRO, J.B., por ser considerado uma referência no estudo da qualidade habitacional em Portugal, através de trabalho expresso na pesquisa - "Definição e Avaliação da Qualidade Arquitetônica Habitacional - LNEC 2003". O desenvolvimento de trabalhos conjuntos das duas entidades de ensino, visando um intercâmbio de dados e pesquisas através de uma visão globalizada, porém não aleatória graças às proximidades culturais advindas do relacionamento histórico Brasil - Portugal, também foram motivo da utilização e estudo do método.

O Método de Pedro, J.B., que foi adotado para este estudo, é baseado em duas diretrizes principais: o Programa de Qualidade Arquitetônica

\footnotetext{
${ }^{1}$ FAPESP 03/09.069-1, 2004 BOUERI J.J., Inventário das Recomendações Dimensionais dos Espaços, Equipamentos e Mobiliário, de agora em diante o texto irá utilizar apenas InventárioBoueri Fapesp, quando fizer referencia a esta pesquisa.

${ }^{2}$ arquiteto pesquisador português do Laboratório Nacional de Engenharia Civil e autor do método de avaliação residencial utilizado nesta pesquisa e ao qual faremos referência de agora em diante como Dr. PEDRO, J.B..
} 
Habitacional e o Método de Avaliação da Qualidade Habitacional. Antes de qualificar estes dois itens é preciso explicar o que se consideram: qualidade e qualidade residencial, pelo método do Dr. PEDRO, J.B. e autores referenciados nos trabalhos de PEDRO 2003 e BOUERI 2005, orientador desta pesquisa.

"Há certas qualidades que podem ser consideradas essenciais em todos os gêneros de casas: sossego, encantamento, simplicidade, largueza de vistas, vivacidade e sobriedade, sentido de proteção e abrigo, expressiva economia na manutenção, harmonia com a envolvente natural e a vizinhança, ausência de lugares escuros e ao abandono, conforto e uniformidade de temperatura, e a possibilidade de cada casa poder ser o adequado quadro doméstico dos seus habitantes. Ricos e pobres, uns e outros apreciarão estas qualidades" (Voysey C. F. A "The English Home" 1911 ). ${ }^{3}$

O conceito de qualidade residencial engloba vários aspectos: o contexto social, o econômico, o cultural e tecnológico, e as condições do meio que a envolve, porém existe um consenso entre os diversos autores e a definição mais adotada é:

Qualidade

O conceito de qualidade é definido como uma adequação das características do produto às necessidades dos usuários.

\section{Qualidade Residencial}

A qualidade residencial pode ser resumida na adequação da habitação e sua envolvente às necessidades dos moradores, porém por possuir características próprias, deve incorporar também;

- Uma possibilidade de adequação em longo prazo.

- Uma possibilidade de adequação sócio-cultural, permitindo a compatibilização das diversas necessidades de cada morador dentro de uma só casa.

${ }^{3}$ http://www-ext.Inec.pt/GH-APPQH/Site/htm/textos.htm 16/01/2007. 
- Uma possibilidade de inovação.

Assim sendo, a definição fica com a seguinte redação: pode-se definir Qualidade Residencial como:

"a adequação da habitação e da sua envolvente às necessidades imediatas e previsíveis dos moradores, compatibilizando as necessidades individuais com as da sociedade, e incentivando a introdução ponderada de inovações que conduzam ao desenvolvimento." (pág.9, PEDRO,2003)

Qualidade Arquitetônica e Urbanística Residencial

- Dimensão espaço-funcional

- Dimensão sócio-cultural

- Dimensão estética

Dentro dos limites da habitação propriamente dita, podemos avaliar dois aspectos diferentes, os chamados mensuráveis ${ }^{4}$ ou ainda especificáveis, segundo SCRUTON, $1979^{5}$ que dizem respeito à funcionalidade, e os não mensuráveis ${ }^{6}$, que dizem respeito à estética e à satisfação do usuário.

"A solução para um problema de projeto só será satisfatória se apresentar, aos que vivem e trabalham com o produto, uma base adequada a compreensão prática deles próprios." (pág.37,SCRUTON, 1979),

Ou seja, faz parte do trabalho do arquiteto projetar os ambientes de forma a facilitar a compreensão e apropriação dos espaços pelos usuários.

Dentre os pesquisadores de qualidade residencial, este trabalho se ateve apenas aos estudos com maior envolvimento na avaliação do dimensionamento, dos ambientes e conseqüentemente da habitação.

\footnotetext{
${ }^{4}$ ou Avaliação Técnica, segundo ORNSTEIN Sheila, 1992. Pág. 18 - Avaliação Pós Ocupação do Ambiente Construído. ORSTEIN .

${ }^{5}$ appud, Pag. 125 BRAGA, Maria Ângela em Qualidade do projeto e Qualidade da HabitaçãoMétodo de Avaliação.

${ }^{6}$ Avaliação do ponto de vista dos usuários ,Pag. 19, Idem 2.
} 


\section{Autores de Métodos de Qualidade Habitacional Referenciados por PEDRO, J.B.: \\ Para o desenvolvimento do METODO, PEDRO cita vários} autores como base bibliográfica, entre eles:

- Método de Análise e Avaliação de Projetos, proposto por Alexandre Klein, anos 30 - Alemanha.

Método Gráfico de análise de plantas, com raízes funcionalistas, foi considerado rigoroso e prático por PEDRO, J.B.. Tem como principal objetivo a satisfação dos usuários em tempo reduzido e baixo custo, visando atender a demanda da época. Orientou seus estudos em busca da habitação mínima, devido à relação entre área construída e custo da unidade, ressalta que:

"a definição da habitação mínima não deveria significar um empobrecimento nas condições de habitabilidade".

Este método poderá ser ilustrado em trabalho de pesquisa de KENCHIAN, Alexandre (2003), anexo 13 desta dissertação, referente ao apartamento $\mathrm{n}^{\circ} 19$ da tipologia T4, que faz parte do universo de habitações estudadas no Capítulo III deste trabalho.

- Método de Racionalização de Soluções da Habitação proposto por Nuno Portas e A. Costa anos 60 e 70 - Portugal.

"Os favelados deverão evoluir até atingir uma renda mínima de consumo, para serem inseridos na vida urbana"7

Este método é aplicado através de um questionário para a definição do programa habitacional que discrimina as exigências de mobiliário e

\footnotetext{
${ }^{7}$ Pag. 2 , PORTAS, Nuno, Definição e Evolução das Normas das Habitações, 1966 Portugal.
} 
equipamentos através das funções de uso seguido da uma análise morfológica do espaço relacionando-os com as funções e atividades.

O que caracteriza este tipo de programa é que a habitação é concebida para responder às exigências definidas de:

- Durabilidade $\longrightarrow$ Evolução da renda e do Status

- Custo $\longrightarrow$ Social do morador

- Conforto - No que tange às exigências humanas.

Acredita que o estabelecimento de um programa de exigências dos usuários é o ponto de partida para o trabalho de concepção do arquiteto, e ao mesmo tempo, ponto de convergência da pesquisa fundamental ou aplicada das ciências humanas e do estudo do entorno arquitetural considerado do ponto de vista do nível de satisfação do usuário.

Completa este estudo com um conjunto de índices e dimensões para os ambientes da habitação, onde define como mínimo: "o limite de qualidades para a satisfação de certas exigências do espaço habitável"s.

\section{- Método Qualitel 1974- França}

Este método foi criado com o intuito de auxiliar os compradores a estabelecer uma avaliação das qualidades construtivas das habitações. Já foi aplicado em mais de 600.000 habitações, segundo PEDRO, ${ }^{9}$ tendo permitido várias atualizações e formulações, acompanhando as alterações no modo de vida das pessoas. O resultado da avaliação realizada através deste método é um relatório claro e simples, contendo o perfil de qualidade e um texto explicativo que permite uma valorização relativa dos vários pontos de vista de acordo com as preferências e necessidades dos usuários.

\footnotetext{
${ }^{8}$ Idem 5

${ }^{9}$ pág. 65, PEDRO, J. B. -Definição e Avaliação da Qualidade Arquitetônica Habitacional LNEC 2003 Portugal.
} 
- Método SEL (Systeme Dévaluetion de Logements) 1975- Suíça.

O método SEL foi introduzido na Suíça, com o objetivo de apoiar uma política pública de incentivo de aquisição e construção de habitações com qualidade, financiadas pelo estado. Busca atribuir um valor de uso a partir do qual se possa atribuir um valor financeiro para a aquisição do imóvel. Dos 66 pontos de vista adotados, os mais próximos da avaliação dimensional são os relativos a habitação, onde se avalia:

- Possibilidade de instalação de mobiliário Ex. extensão de paredes mobiliáveis.

- Possibilidade de adaptação - Ex. futuras mudanças

- Satisfação de exigências fisiológicas e funcionais. - Ex. equipamento sanitário, isolamento acústico.

Assemelhando-se muito com o método de PEDRO, na formulação da síntese dos resultados e na ponderação que também foi organizada por um grupo de especialistas em qualidade da habitação e outro grupo de usuários, podendo ter os pontos de vista analisados individualmente para agregá-los posteriormente, como na aplicação do METODO realizada nesta pesquisa, vide capítulo III deste trabalho.

\section{- Método Dluhousen 1989 -EUA}

O método proposto por Dluhousen visa avaliar as habitações quanto à satisfação das necessidades objetivas e quantificáveis dos futuros usuários. O método é organizado em 43 pontos, dividos em:

- habitação propriamente dita,

- envoltória próxima e

- envoltória alargada.

Dentro da Habitação, dedica-se entre outros pontos, aos espaços e dimensões, onde sugere um programa de espaços, baseado nas áreas dos ambientes e na relação entre a áreas de circulação e a áreas habitáveis. A qualidade do espaço é avaliada por um critério de dimensões mínimas e máximas dos compartimentos. 
- Foram citados também, outros estudos desenvolvidos pelo LNEC, em Portugal.

\section{O Método de PEDRO, João Branco}

O Método de Pedro, J.B., que foi adotado para este estudo, é baseado em duas diretrizes principais: o Programa de Qualidade Arquitetônica Habitacional e o Método de Avaliação da Qualidade Habitacional.

A definição do Programa de Qualidade Arquitetônica Habitacional é o primeiro passo do processo; é onde se organizam os dados do problema e definem-se as exigências de qualidade aplicáveis. Foi lastreado em 3 bases de dados:

a. Bibliografia (portuguesa e estrangeira).

b. Análise de soluções existentes.

c. Realização de modelos de ensaio.

A definição do programa tem muitas similaridades com as pesquisas desenvolvidas pelo prof. Dr. Boueri J.Jorge, constantes no Inventário Boueri Fapesp, como por exemplo:

a. Os autores do embasamento teórico

b. A análise das soluções utilizadas e

c. Os modelos dos arranjos utilizados.

O Método de Avaliação da Qualidade Habitacional foi desenvolvido com base nas exigências formuladas no Programa Habitacional, segundo um modelo de "multicritério" e sua aplicação insere-se numa filosofia de "processo de apoio à decisão", visando auxiliar no processo de decisões sobre a habitação, mesmo quando ainda em projeto, realizando avaliações objetivas de empreendimentos habitacionais.

"O Método de Avaliação mede o grau de satisfação das exigências, com base nos dados fornecidos pelos utilizadores,... pois a interpretação dos resultados de uma 
avaliação não deve ser desligada dos dados que fundamentam"10.

\subsection{O Programa de Qualidade Habitacional}

\subsubsection{A Definição do Programa Habitacional}

A definição de um Programa Habitacional é a $1^{\mathrm{a}}$ etapa da Aplicação do Método, sendo possível dividi-la em:

a. Identificação e Classificação dos Usuários

$\mathrm{Na}$ identificação e classificação dos usuários, são analisados os tipos de família, o ciclo de vida e os hábitos familiares. Para os tipos familiares, foram indicados os mesmos critérios utilizados pelo Grupo de Pesquisa - Nômads ${ }^{11}$.

b. Classificação de Espaços Habitacionais

Além dos autores citados no capítulo II e por ser considerada atividade que resulta da observação e senso comum, segundo Dr.Pedro, J.P. na classificação dos espaços residenciais, devem ser considerados os seguintes aspectos:

- Adotar uma estrutura sistemática, de modo que cada espaço seja localizado facilmente dentro da estrutura geral.

- Adotar designações de linguagem de uso corrente.

- Deve se realizar uma delimitação clara no âmbito das designações adotadas,

- Foi adotada a classificação dos compartimentos em zonas residenciais ${ }^{12}$, a saber:

zona intima, dormitórios, banheiros sociais e salas íntimas.

zona social, salas de estar, jantar, lavabos e halls de entrada.

\footnotetext{
${ }^{10}$ Pág. 96 parte III , idem 9.

11 Conforme subdivisão das zonas residenciais adotada pelo Grupo coordenado pelo Prof. TRAMONTANO, Marcelo na EESC - USP.

${ }^{12}$ Foram adotadas as zonas residenciais segundo; WITOLD, em "Pequena História de uma Casa", que correspondem também às adotadas no método utilizado.
} 
zona serviços , cozinhas, copas, áreas de serviço, dependências de serviços, despensas.

zona de circulação.

c. Classificação de Funções de Uso em ordem Hierárquica.

As funções são definidas através do comportamento que usualmente é utilizado na organização do espaço habitacional, da seguinte forma:

- Ações - conjunto de atos limitados.

- Atividades - seqüência de ações.

- Funções - conjunto de sistemas de atividades que formem uma unidade de comportamento.

- Padrões - Agrupamento de funções.

- Processos/ Ciclos - ex. Ciclo de Vida.

Para a aplicação do Método foi utilizado o Conjunto de Funções e Atividades na Moradia da Cidade de São Paulo, resultado da pesquisa realizada pelos professores, Dr. BOUERI J.J. e pelo Dr. PEDRO J.B., dentro da disciplina da AUT 5807 da CPG FAU USP em março de 2006, vide anexo 5 deste capítulo.

\section{Exemplo:}

Quadro Sinóptico

Funções e Sistemas de Atividades nos Edifícios Residenciais da Cidade de São Paulo -2006

\begin{tabular}{|l|l|}
\hline Função & Sistema de Atividades \\
\hline 1. Repouso Pessoal & a) Dormir | descanso de casal \\
\hline & b) Dormir | descanso individual/duplo \\
\hline & c) Dormir | descanso de crianças \\
\hline & d) Convalescer \\
\hline & e) Permanência em reservado \\
\hline 2. Preparo de Refeições & a) Preparação de alimentos \\
\hline & b) Arrumação de louças e utensílios \\
\hline & c) Tratamento de resíduos \\
\hline 3. Refeições & a) Refeições correntes \\
\hline & b) Refeições formais \\
\hline & c) Estar à mesa \\
\hline
\end{tabular}




\section{d. Tipologias}

"Tipo corresponde a uma imagem descritiva de uma tipologia constituindo uma unidade autônoma e paradigmática. O tipo não constitui uma imagem a ser copiada, mas uma idéia para servir de modelo gera l".(pág.28, PEDRO,2003)

As tipologias de apartamentos utilizadas no Inventário BOUER| FAPESP em 2004, foram também utilizadas na aplicação do método, pois são muito próximas da utilizada pelo Dr.Pedro, ou seja;

Divisão dos apartamentos pelo número de dormitórios:

T1 - Habitações de 1 dormitório

T2 - Habitações de 2 dormitórios
T3 - Habitações de 3 dormitórios

T4 - Habitações de 4 dormitórios

As habitações de um dormitório não estão incluídas neste estudo, devido a pouca representatividade no universo levantado no Inventário BOUERI FAPESP.

\subsubsection{Exigências de Qualidade}

As exigências de qualidade são a $2^{\mathrm{a}}$ parte do Programa Habitacional, que por sua vez é uma das duas diretrizes do método em estudo. É a etapa onde são definidos "os níveis de desempenho dos espaços e das unidades de construção do habitat ${ }^{13}$, visando a satisfação dos usuários. As exigências foram organizadas em uma árvore de importância.

\footnotetext{
${ }^{13}$ Pág. 29, idem 9
} 
Quadro 1- Arvore de Classificação de Exigências de Qualidade Habitacional, adotada no método do Dr. Pedro, J.B. ( a nomenclatura pertence ao METODO)

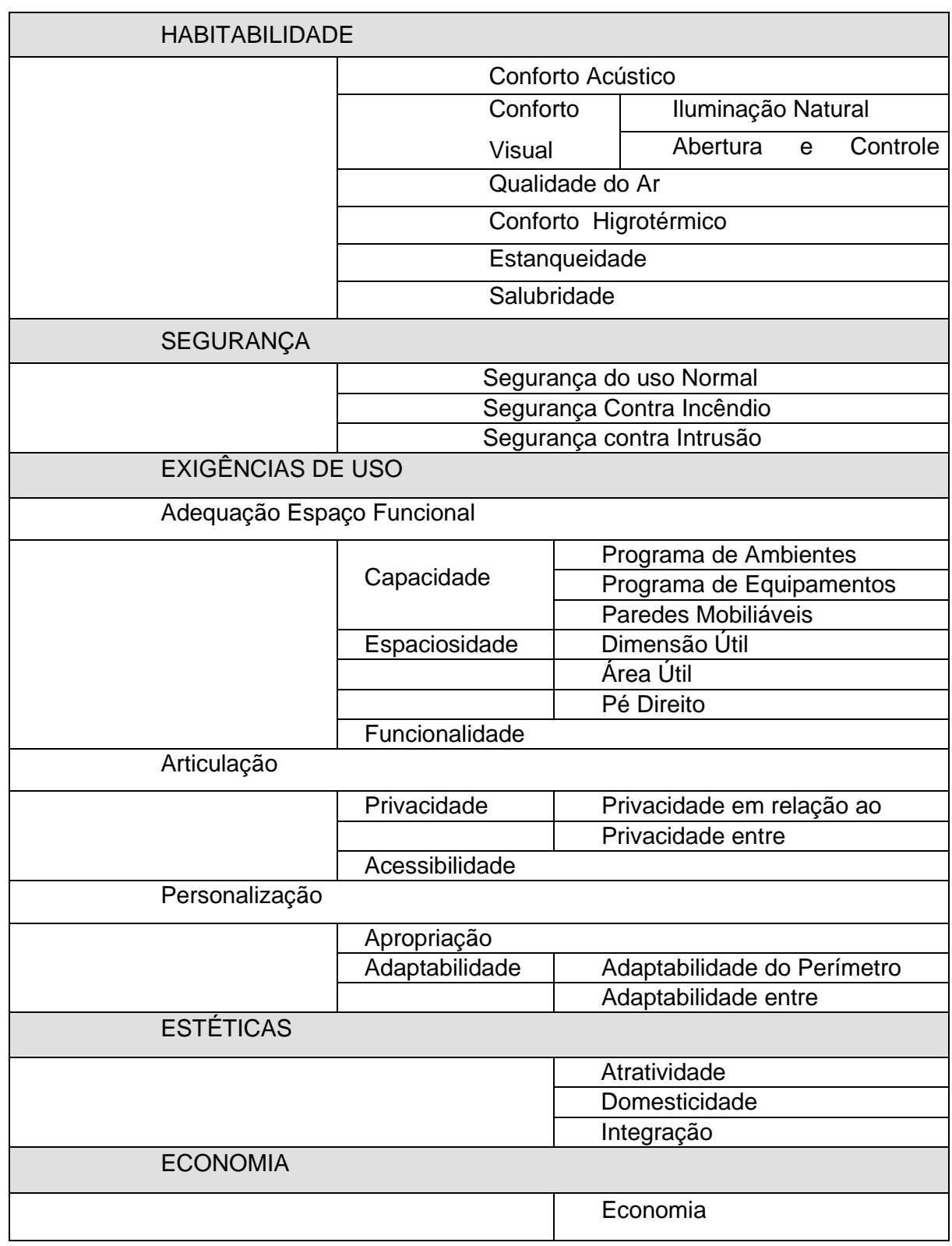




\section{a . Formulação da Qualidade}

Devido à variação das necessidades dos usuários durante a vida útil da construção, que acontece principalmente ao longo do ciclo de vida familiar, e com o desenvolvimento sócio-econômico da sociedade onde estão inseridas as habitações, o método adotado parte do suposto de que é possível generalizar sobre as necessidades e definir exigências de qualidade aplicáveis no âmbito de uma cultura e de um nível sociais de referência.'.

"Para formular exigências de qualidade de modo a permitir responder a diferentes necessidades dos usuários e a sua evolução, deve-se adotar o conceito de "formulação exigencial "(pág. 34, PEDRO, 2003)".

A formulação exigencial é um dos itens da formulação da qualidade, é quando se definem os objetivos a atingir e deixa-se em aberto a forma prática para resolver cada situação concreta. No desenvolvimento da formulação exigencial verifica-se 3 níveis, a saber:

- exigência dos usuários - bem estar, saúde e satisfação.

- exigências de qualidade de comportamento e desempenho da edificação conjunto de características espaciais e ambientais que permitem o desempenho de cada atividade nos espaços edificados.

- exigências de qualidade de comportamento ou desempenho da obra civil (material empregado e mão de obra utilizada).

Entre as principais vantagens da formulação exigencial, destacam-se a elaboração de soluções inovadoras e a possibilidade de manter os documentos técnicos atualizados por um período de tempo maior, diferente das exigências prescritas (quando a solução é imposta, rígida) .

b. Definição dos Níveis de Qualidade

A qualidade representa um conceito abstrato, sendo assim necessária uma forma de quantificá-la para que possa ser avaliada. Um nível de qualidade é constituído por um conjunto de exigências que define um determinado patamar 
de satisfação dos usuários, considerando as possibilidades sociais, econômicas e técnicas de cada momento. ${ }^{14}$ Os níveis de qualidade foram fixados em:

Nulo (Básico) / Mínimo / Recomendável (Médio) / e ótimo (Máximo). Para sua fixação devem se levar em consideração os estudos sobre as características físicas, sociais e psicológicas da população. Ex.:

- modo de vida

- necessidades e aspirações

- entendimento de como se efetua a satisfação

Em caso de nível mínimo de qualidade da habitação podem ser adotar os seguintes critérios ${ }^{15}$ (Portas, 1969, Cabrita 1987):

- Adequação às necessidades ergonômicas, antropométricas e sociológicas das funções de uso da habitação.

- Adequação às necessidades vitais - segurança e saúde

- Adequação às perspectivas de evolução das necessidades familiares

- Adequação às limitações impostas - exeqüibilidade econômica, legislação.

c. Condições do Meio de uma Área Residencial

- Meio Físico :Condições naturais: clima / solo / dados fisiográficos (hidrografia) / dados biológicos (vegetação).Condições criadas pelo homem: Conforto ambiental / segurança / espaços funcionais / articulação / personalização e estética.

- Meio Social e Cultural aonde são considerados; a composição social, os agregados familiares e vizinhança.

- Modos de vida aonde são considerados os hábitos de uso dos espaços: comuns, privados e públicos. Abertura e a viabilidade de possíveis mudanças.

d. Fontes para a Definição de Exigências de Qualidade

- fontes bibliográficas

- legislação e normas em vigor

- regulamentos e normas estrangeiras

\footnotetext{
${ }^{14}$ Pág. 35, idem 9.

15 PEDRO, apud (Portas, 1969, Cabrita 1987) idem 9
} 
- estudos gerais e específicos

- estudos sobre satisfação residencial dos usuários, tratados como consumidores de um produto.

Quanto à bibliografia estrangeira é interessante notar que quando vinda de países com hábitos semelhantes, permite comparar e complementar; quando vinda de paises de hábitos semelhantes, porém, mais desenvolvidos, auxilia a prever a evolução provável das exigências.

\subsubsection{Modelos de Composição de Ambientes}

Constituem a $3^{\mathrm{a}}$ fase do programa habitacional e é onde se apresentam exemplos da aplicação das exigências de qualidade aos tipos habitacionais mais freqüentes.

$\mathrm{Na}$ aplicação do Método, não foram utilizados modelos para exemplificar as exigências, apenas os espaços de atividades que circundam o mobiliário e os equipamentos. As plantas dos empreendimentos estudados no Inventário Boueri FAPESP tiveram os seus ambientes levantados para posterior análise das soluções mais freqüentes quanto à composição do mobiliário e equipamentos (Vide anexo 4).

\subsection{O Método de Avaliação da Qualidade Residencial}

Para realizar uma avaliação complexa é em regra necessário organizar o objetivo geral em vários sub-objetivos, ponderar a importância relativa de cada um, e chegar a um resultado de síntese. Considera-se fundamental o esclarecimento de 2 conceitos para a elaboração de um método de qualidade arquitetônica:

a. Processo de Apoio à Decisão

b. Método de Avaliação Multicritério 


\subsubsection{Processo de Apoio a Decisão}

A tomada de decisão no ato de projetar é atividade cotidiana e nem sempre é possível justificar a decisão nem tomá-la imediatamente. Existem situações onde o processo é mais complexo, envolvendo a ponderação de um conjunto de aspectos intuitivos. O Processo de Apoio a Decisão tem por objetivo formular e modelar uma estrutura de decisão aceita por todos os participantes do processo - a chamada fase de formulação - e posteriormente elaborar métodos e técnicas para a aplicação dessa estrutura de decisões - a chamada fase de avaliação.

a. Fase de Formulação

A fase de formulação é composta das seguintes etapas:

- Definição dos problemas

- Identificação dos atores e dos objetivos

- Definições das ações e identificação das características

b. Fase de avaliação

A fase de avaliação é quando são desenvolvidos os modelos de avaliação, sendo composta de:

- Aplicação do modelo.

- Representação e análise dos dados obtidos.

\subsubsection{Método de Avaliação por Multicritério}

Este método permite subdividir uma avaliação global num conjunto de avaliações individualizadas e objetivas, com pesos distintos para a obtenção da avaliação global, compreendendo os seguintes itens:

\section{a. Arvore dos Pontos de Vista}

Os pontos de vista são utilizados para designar uma característica (atributo ou fator relevante) para a avaliação. Podem ser organizados de forma hierárquica, formando assim a árvore dos pontos de vista. Os pontos de vista no topo da árvore são chamados de principais e os da base da árvore são 
denominados pontos de vista elementares. Na definição da árvore dos pontos de vista, devem ser ponderados os seguintes aspectos:

- exaustividade

- operacionalidade

- decomponibilidade (cada ponto de vista pode ser avaliado independentemente)

- dimensão mínima

- subdivisão limitada

- hierarquia mínima

b. Pontos de Vista Elementares

São aqueles diretamente quantificáveis, por medição ou observação. Ex.: área útil, o coeficiente entre a área útil de janela e a área do compartimento.

\section{c. Descritores}

Permite quantificar em uma escala numérica o desempenho dos pontos de vista, com as seguintes características:

- a mesma escala para todos os pontos de vista.

- desempenho nulo deverá corresponder ao mesmo valor da escala do descritor para todos pontos de vista.

- o sentido de preferência das escalas deverá ser o mesmo em todos os pontos de vista.

\section{d. Critérios de Avaliação}

É a metodologia que permite relacionar uma característica do ponto de vista, com um valor da escala do descritor, podendo tomar a forma de lista de exigências ou funções de transformação:

- Lista de Exigências - seqüência de exigências quantificáveis.

- O tipo de escala da função de transformação pode ser dicotômico (falso e verdadeiro) ou numérico ordinal (área útil de um compartimento). 


\section{e. Critérios de Ponderação}

Definem a importância dos sub-pontos de vista, na avaliação do ponto de vista de hierarquia superior. É a forma de manifestação dos participantes no processo de decisão.

\subsubsection{Método para Obtenção da Síntese.}

Permite conjugar os valores de desempenho de cada opção segundo os pontos de vista pré-estabelecidos e o critério de ponderação adotado.

a. Método aditivo simples

É constituído por médias aritméticas dos sub-pontos de vista, que integram o ponto de vista hierarquicamente superior e assim por diante, conforme a formula abaixo:

$V p v=\frac{\sum_{i}^{n s p v}(V s p v i \times P s p v i)}{\sum_{i}^{n s p v} \operatorname{Pspvi}} \quad \begin{aligned} & \text { Aonde: } \\ & \text { Vpv }=\text { valor do ponto de vista } \\ & \text { Vspv }=\text { valor do sub ponto de vista } \\ & \text { Pspv }=\text { ponderação do sub ponto de vista } \\ & \text { Nspv }=\text { número de sub pontos de vista }\end{aligned}$

b.Forma de Apresentação dos Resultados

- valor de desempenho global

- relatório descritivo

- gráfico de desempenho por ponto de vista / perfil de qualidade

C. Análise dos Resultados

- análise custo benefício

- análise de sensibilidade, analisa as alterações de valor de desempenho que possam vir a existir, caso uma alternativa seja alterada, o que ocorre simulando outras ponderações e ou utilizando outros pontos de vista, para os elementos escolhidos.

- Valor de desempenho global / unidade. 


\section{Qualidade do Dimensionamento dos Ambientes da Habitação segundo o Prof. Dr. BOUERI, J.J.}

O trabalho acadêmico do Prof. Dr. BOUERI, J.J. tem como foco principal o ensino e a pesquisa do dimensionamento da habitação fundamentados em preceitos de ergonomia e antropometria através da disciplina AUT 5807 - Modelos de Dimensionamento da Habitação ministrado no CPF FAU USP, desde 1991, e grupo de Pesquisa do qual o autor faz parte, que visa um aprofundamento nos estudos da qualidade dimensional da habitação relacionados as dimensões do corpo humano. Bases adotadas para o desenvolvimento das pesquisas:

- Fatores ergonômicos (humanos e ambientais) que influenciam no uso dos espaços edificados, seus equipamentos e mobiliário. A ergonomia aplicada à arquitetura e urbanismo conceitua-se pelos estudos das atividades humanas no ambiente construído. Para o conhecimento do corpo humano é de fundamental importância o estudo da antropometria.

- Estudos Antropométricos como o conhecimento científico relacionado ao estudo do corpo humano em suas dimensões e seus limites, os padrões antropométricos.

- A acessibilidade e o dimensionamento, este dueto é de vital importância, pois os espaços previstos devem prever o acesso a todas as pessoas, ressaltamos em especial os grupos mais vulneráveis: as crianças os idosos e os deficientes físicos.

- A análise de tarefas ou atividades desenvolvidas no espaço habitacional,. Como uma metodologia de trabalho proveniente da Ergonomia. (vide fig. 04 deste capítulo)

- A importância destes estudos para a formação dos novos profissionais, na disciplina de projeto.

- O espaço de atividades, que resulta de um estudo de posturas corporais que determinam a necessidade espacial para que a atividade seja realizada de maneira eficiente e segura.(O espaço de Atividades foi utilizado neste trabalho na aplicação dos 2 métodos) 
- Outros fatores que influenciam na determinação do espaço construído, tais como: legislação e normas, hábitos e ciclo da família, técnicas de arranjos, fluxos de circulação e modelos de dimensionamento desenvolvido por vários autores.

- O dimensionamento mínimo e a habitação social.

Dentre os inúmeros autores referenciados pelo Prof. Dr. BOUERI, J.J., serão citados os mais significativos para o estudo da avaliação da qualidade dimensional, recomenda-se KENCHIAN, Alexandre $(2004)^{16}$, para maiores detalhes e um estudo mais aprofundado de todos os autores e seus métodos. Entre os autores citam-se os seguintes trabalhos:

\section{- Vitruvius}
"A história nos mostra que vários estudos foram realizados para a sistematização das medidas do corpo humano e suas relações com os espaços construídos. Em seu tratado Da Arquitetura, Vitrúvio relata as várias proporções encontradas nas obras de Arquitetura e as relaciona com as partes do corpo humano, descreve ainda as proporções entre as partes do corpo humano, elaborando o Homem Vitruviano. Este estudo nos mostra a preocupação em aplicar as dimensões do corpo humano na composição dos espaços da Arquitetura." ${ }^{17}$

"De Architedtura Libri Decem" livro de Vitruvio Polião, traduzido para o português ${ }^{18}$ em 1997, prefaciado por Julio Katinsky. Datado do século I a $\mathrm{C}$, em especial no livro Terceiro, que trata das proporções do corpo humano. Aonde define como semelhança :

"Semelhança é a correspondência entre as medidas de cada um dos elementos das partes da obra e ela como um todo, de onde resulta a relação entre as

\footnotetext{
${ }^{16}$ Dissertação de Mestrado 2004.Estudo de Modelos e Técnicas de Projeto e Dimensionamento dosEspaços da Habitação. FAU USP

${ }^{17}$ BOUERI 2004 Tese de Livre Docência CPG FAU USP.

${ }^{18}$ Vitrúvio Polião, Marco - Vitrúvio da Arquitetura, São Paulo, - Editora Hucitec/Annablume, 2002
} 
proporções.De fato nenhum templo pode ser bem composto sem que se considere alguma proporção ou semelhança, a não ser que tenha exatas proporções, como as dos membros segundo uma figura humana bem constituída."Vitruvius, séc. I a.C.". ${ }^{19}$
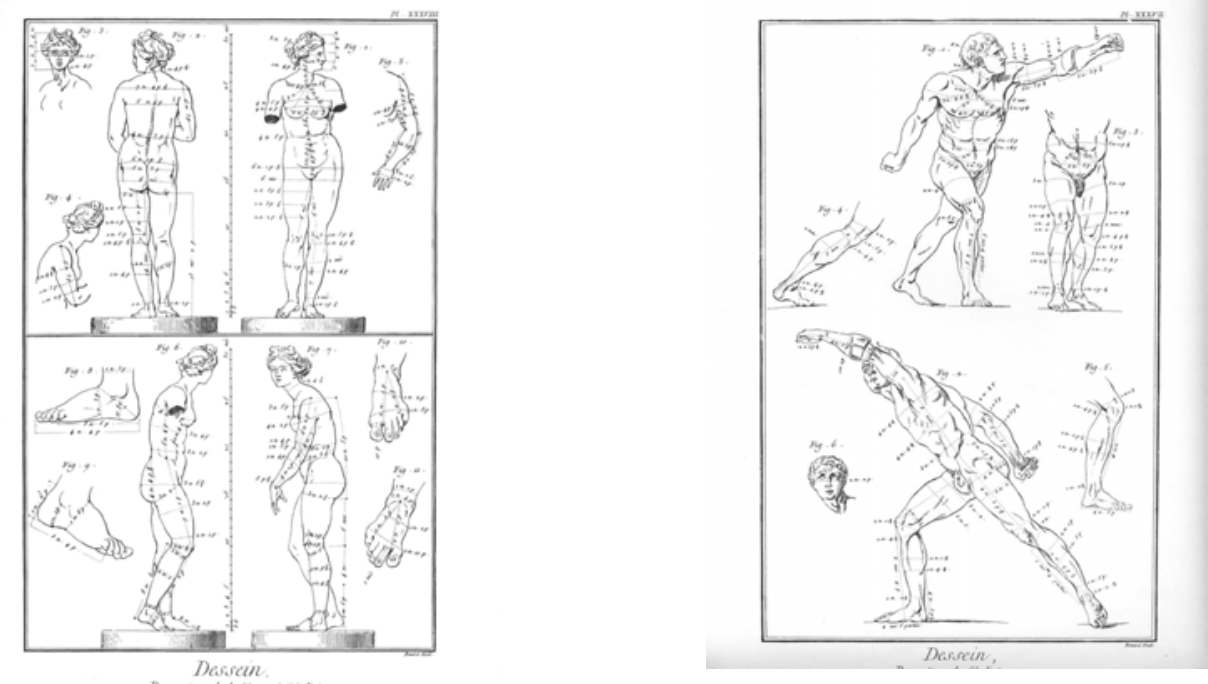

Fig. II 01 e II 02 Ilustração das Proporções do Corpo Humano - Dessen Fonte: www.ac-versailles.fr/pedagogi/artsplastiques/...

- II CIAM - Congresso Internacional de Arquitetura

Embasados nos fundamentos da Revolução Industrial, os arquitetos que participaram do II CIAM - Congresso Internacional de Arquitetura Moderna ${ }^{20}$ discutiram sobre a nova visão das habitações e como estas deveriam cumprir o papel de proporcionar aos seus usuários a possibilidade de desenvolverem as atividades pertinentes ao habitar. O congresso via claramente :

"Que o mínimo (2000 a 2500 marcos) no podía ser tomado como medida económica para la vivienda mínima, para la ración de <vivienda> sino que aquí se trataba de establecer ante todo un mínimo biológico." ${ }^{21}$

\footnotetext{
19 idem 10,Pág. 92 Livro $3^{\circ}$.

${ }^{20}$ AYMONINO La vivienda Racional -1930 Roma

${ }^{21}$ Pág. 106 ibdem 20
} 


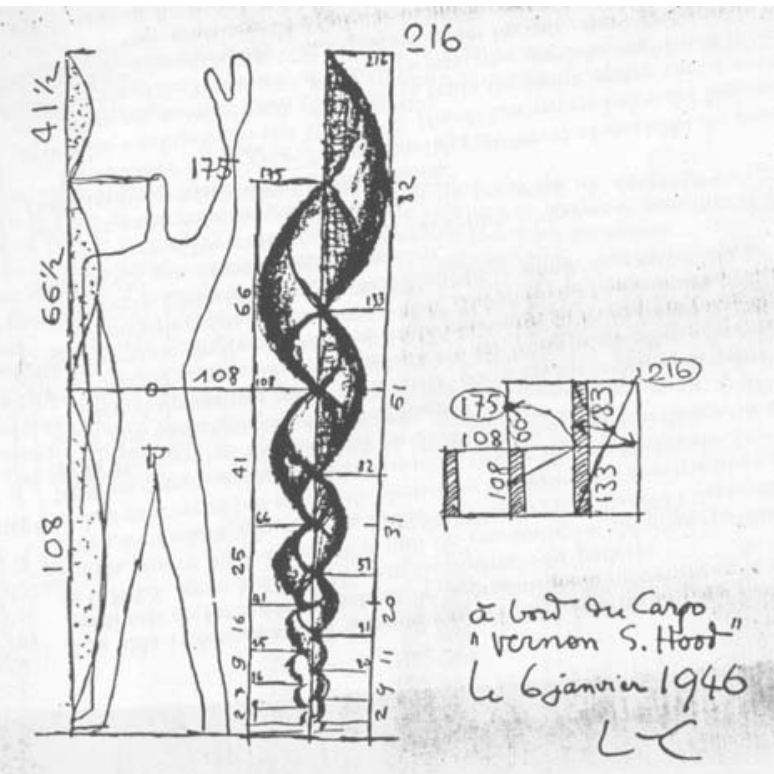

Fig.II 02 - "Modulor 1" -

Primeiro Estudo de Traçados Geométricos

Fonte-www.architektur.tu-

darmstadt.de/upload/powerh
No século XX, 2.000 anos após Vitruvius escrever seus dez livros Le Corbusier reviveu o interesse do projeto de arquitetura estudado através das medidas do corpo humano, com a criação do Modulor, com o propósito de que esse servisse para unificar os sistemas de medidas métrico e britânico, buscando uma padronização das medidas utilizadas pelos projetistas, facilitando assim a padronização para e a industrialização dos elementos construtivos.

"Toda idéia, todo o esforço, é um sentido de uma melhor compreensão entre os homens e uma aproximação entre os povos, e toda ação que concorra a fazer surgir à consciência de uma unidade mundial é uma preciosa contribuição"( LE CORBUSIER, 1961) ${ }^{22}$

Enquadrou este estudo nos princípios modernos do módulo função, ou seja, parte da idéia que o homem realiza uma ou mais atividades em um determinado espaço ${ }^{23}$.

Os estudos para Marselha, relacionam suas atividades anteriores. Este projeto foi o primeiro teste do sistema de medidas criado por Le Corbusier a aplicação do sistema Modulor 2 . Os apartamentos são constituídos por

\footnotetext{
${ }^{22}$ LE CORBUSIER, 1961 pag116 "Le Modulor “, Buenos Aires.

23 idem 13.
} 
pequenos ambientes com alturas de pé direito correspondentes à altura de braços erguidos de uma pessoa,

Em texto de POSSEBON, Enio, para o IMAE ${ }^{24}$, "O Modulador de Le Corbusier, Forma Proporção e Medida da Arquitetura", cita comentário de NEUFERT , Ernst, (1965) em seu livro "A industrialização das Construções" (pág 35), com relação às aproximações e arredondamentos de medidas estabelecidos nas séries vermelha e azul, do Modulor:

[...] é importante que um arquiteto de tanta popularidade com o Le Corbusier tenha dedicado sua atenção ao problema das medidas na construção e que tenha colocado em primeiro plano necessidades arquitetônicas que haviam sido deixadas de lado, como pouco acertadas, substituídas por normatizadores mecânicos e exclusivistas.

Não menos importante é o fato de que para desenvolver as construções se possa jogar com proporções baseadas na secção áurea"

\section{- O Modelo Inglês para o Desenvolvimento Habitacional}

Dentro desse contexto, foram elaborados pelo governo inglês uma série de boletins direcionados a habitações projetadas para o setor público, porém com alcance para os demais interessados. Suas recomendações são baseadas em pesquisas sobre as necessidades e atitudes dos usuários, empreendidas pelo Ministério da Habitação Britânico entre 1968 e 1972 .

O Design Bulletin 6 - "Space in the Home" parte de detalhes, e exigências espaciais vinculadas às atividades desenvolvidas no espaço doméstico devido a evolução das famílias e ao tipo de mobiliário e equipamentos utilizados. O "Design Bulletin 14 - House Planning: a guide to users needs with a check list" pode ser considerado como uma coleção de elementos analíticos de um projeto habitacional, onde todos os envolvidos se apropriam de itens de avaliação dentro do planejamento do projeto.

${ }^{24}$ IMAE - Instituto Metropolitano de Altos estudos da Faculdades Metropolitanas Unidas, R. Cult. : R. IMAE, São Paulo, a.5, n. 11, p. 68-76, jan./jun. 2004 


\subsection{Antropometria para Arquitetura Habitacional Dissertação de} Mestrado FAU USP 1985

A dissertação de mestrado foi a primeira contribuição para o estudo da antropometria e ergonomia relacionando-as ao dimensionamento na arquitetura. Foram pesquisadas as implicações das dimensões corporais no projeto e na construção habitacional, incluindo os aspectos culturais e étnicos que também influenciam na ocupação do espaço edificado.Esta pesquisa deu origem a publicação do livro Antropometria Aplicada à Arquitetura, Urbanismo e Desenho Industrial, em 1999.

\subsection{Antropometria Fator de Dimensionamento da Habitação.}

Tese de doutorado,1989, sobre a antropometria aplicada a Habitação, que foca os movimentos do ser humano como determinantes da forma e dimensionamento dos ambientes e mobiliários na habitação.Este livro teve como meta servir de ferramenta no ensino da arquitetura, avaliando qual o espaço necessário para realização de determinadas atividades, através do estudo da decomposição dos movimentos do corpo humano.

A importância deste estudo pode ser exemplificada com as variações antropométricas que acontecem nas pessoas em função do aumento da idade, requerendo estudo especial dos ambientes, em especial do ambiente doméstico.
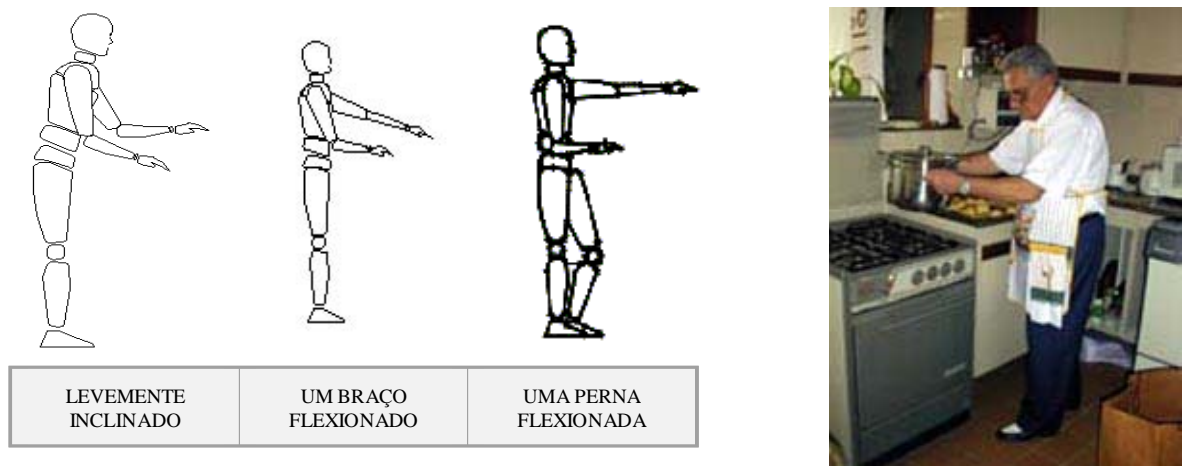

Fig. II 04 Desenhos e Fotos Ilustrativas das Atividades nas Cozinhas Fonte: Trabalho Proqramado do autor. 


\section{3 Índices de Avaliação Ergonômica do Dimensionamento da Habitação,}

Tendo como referencia a Tese de Doutorado defendida em 1989 por BOUERI, J. J., e os estudos e pesquisas desenvolvidos nas disciplinas do curso de pós graduação da FAU USP, o estudo da ergonomia aplicada aos ambientes da habitação permitiu a elaboração uma metodologia que engloba um conjunto de critérios que têm por objetivo avaliar o projeto e o pré-uso dos espaços do da habitação o qual denominou "Índices Ergonômicos do Dimensionamento da Habitação". 25

Os índices são compostos de cinco itens;

- Área Útil da Habitação

- Área Útil do Ambiente

- Composição do Mobiliário e Equipamento

- Conexões de Portas e Janelas

- Tipologia da Habitação e Ciclo Familiar

Através de delimitação de faixas de áreas de varredura ${ }^{26}$ das habitações e dos ambientes, gerando um critério de avaliação aonde os itens acima são classificados em:

- bom, 4

- satisfatório 3

- regular 2

- precário 1

\section{Área Útil da Habitação}

"É a capacidade dimensional da Habitação em suportar, no conjunto dos ambientes, a execução das tarefas domésticas de formas adequadas, eficientes e seguras, obtida pela divisão da Área Útil Total da Habitação pelo número de usuários, expressa em metros quadrados e que classificam a habitação."

A qual é expressa em metros quadrados por habitante.

\footnotetext{
${ }^{25}$ BOUERI, J.J. 2001Apostila da AUT 5809 Modelos de Dimensionamento dos Ambientes da Habitação

${ }^{26}$ áreas de varredura ou líquidas são as consideradas sem paredes

${ }^{27}$ idem 1
} 
Tabela 1- Área Útil da Habitação Fonte Boueri

\begin{tabular}{|c|c|c|}
\hline \multicolumn{2}{|c|}{ Área Útil da Habitação } & AEDH1 \\
\hline \multicolumn{2}{|c|}{ Índice } & Critério \\
\hline B & 4 & 16 a $14 \mathrm{M}^{2}$ Habitantes \\
\hline $\mathrm{S}$ & 3 & 14 a $12 \mathrm{M}^{2}$ Habitantes \\
\hline & 2 & 12 a $10 \mathrm{M}^{2}$ Habitantes \\
\hline PR & 1 & 10 a $8 \mathrm{M}^{2}$ Habitantes \\
\hline
\end{tabular}

Valores da escala de avaliação:

$\mathbf{B}=$ bom $=4, \quad \mathbf{S}$ satisfatório $=3, \quad \mathbf{R}$ regular $=2, \quad \mathbf{P R}$ precário $=1$

Área Útil do Ambiente

É a capacidade dimensional do ambiente em suportar a execução das tarefas domésticas de forma adequada, eficiente e segura. É expresso em metros quadrados por habitante.

Tabela 2 Área Útil do Ambiente

Fonte Boueri

\begin{tabular}{c|c|c|c|c|c|c|c}
\multicolumn{1}{c|}{ Índice } & Sala & $\begin{array}{c}\text { Dormitório } \\
\text { Casal }\end{array}$ & $\begin{array}{c}\text { Dormitório } \\
\text { Duplo }\end{array}$ & $\begin{array}{c}\text { Dormitório } \\
\text { Simples }\end{array}$ & Cozinha & $\begin{array}{c}\text { Área de } \\
\text { Serviço }\end{array}$ & Banheiro \\
\hline B $\quad 4$ & 18 a 15 & 18 a 15 & 15 a 12 & 12 a 10 & 12 a 10 & 12 a 10 & 6 a 5,5 \\
\hline S $\quad 3$ & 15 a 12 & 15 a 12 & 12 a 10 & 10 a 9 & 10 a 8 & 10 a 8 & 5,5 a 5,0 \\
\hline R $\quad 2$ & 12 a 9 & 12 a 9 & 10 a 8 & 9 a 8 & 8 a 6 & 8 a 6 & 5,0 a 4,5 \\
\hline PR 1 & 9 a 6 & 9 a 6 & 8 a 6 & 8 a 6 & 6 a 4 & 6 a 4 & 4,5 a 4 \\
\hline
\end{tabular}

Valores da escala de avaliação: $\mathbf{B}$ bom $=4 \quad \mathbf{S}$ satisfatório $=3 \quad \mathbf{R}$ regular $=2 \quad \mathbf{P R}$ precário $=1$

\section{Composição de Mobiliário e Equipamento}

É a capacidade do ambiente em de receber mobiliário e ou equipamentos necessários ao desempenho das atividades domésticas, podendo suportar um acréscimo ou uma inovação de atividades dentro deste espaço.

Tabela 3 Composição de Mobiliário e Equipamentos Fonte Boueri

\begin{tabular}{cc|c}
\multicolumn{5}{c|}{ Composição de Mobiliário e Equipamentos AEDH3 } \\
\hline \multicolumn{2}{c|}{ Índice } & Critério \\
\hline B & 4 & O ambiente suporta adicionar mobiliário e equipamento básicos com dimensões usuais. \\
\hline S & 3 & O ambiente suporta o mobiliário e equipamento básico com dimensões usuais \\
\hline R & 2 & O ambiente suporta o mobiliário e equipamento básico com dimensões reduzidas aos usuais \\
\hline PR & 1 & O ambiente não suporta o mobiliário e equipamento básico com dimensões usuais \\
\hline
\end{tabular}


Para a aplicação dos índices foram adotados como elementos necessários aos ambientes os equipamentos e mobiliários, constantes no Inventário Boueri FAPESP, nos quadros de composição de ambientes., quando a incidência era maior que $45 \%$, exemplo; o freezer apareceu em pelo menos 45\% dos apartamentos de 3 dormitórios.

Conexões de Portas e Janelas

Este elemento não será avaliado, conforme, por que o universo da pesquisa foi retirado de desenhos publicitários, do mercado imobiliário, não possuindo, portanto, estas informações.

Tipologia da Habitação e o Ciclo Familiar

Este elemento não será avaliado, por que o universo da pesquisa não fornece dados suficientes, não tendo também sido questionada a colocação de mobiliário, ou seja, todos os empreendimentos foram analisados com base no mobiliário constante nos desenhos publicitários, não foram feitos estudos ou modelos alterando a informação previamente fornecida.

\subsection{Espaços de Atividades}

Os "Espaços de Atividades" ${ }^{28}$, constam da Tese de Livre Docência, 2004 e também são fundamentados em preceitos ergonômicos e antropométricos para a população da cidade São Paulo. Formam uma síntese dos estudos e trabalhos anteriores.

Têm como principal finalidade a liberação do ato de projetar desvinculando as atividades dos ambientes, servindo de ferramenta de trabalho para as inovações projectuais que vierem a surgir, preconizando a busca da

\footnotetext{
${ }^{28}$ BOUERI, J.J. 2004 - A contribuição da Ergonomia na Formação do arquiteto-Tese de Livre Docência FAU USP - São Paulo.
} 
qualidade através de processo dinâmico e ao mesmo tempo cíclico aonde as necessidades e preferências dos usuários podem variar.

\section{Síntese do Capítulo}

Este capítulo fez um breve preâmbulo ao estudo da qualidade que fundamentou o trabalho prático de avaliação da qualidade dimensional habitacional em apartamentos constante no capítulo III.

Em primeiro lugar situamos o estudo e as definições de qualidade, qualidade habitacional e dimensional que forneceram o embasamento teórico para esta pesquisa, incluindo os principais autores que citados por PEDRO, J.J.

A segunda etapa foi um breve sumário das etapas do METODO a ser aplicado e as adaptações que se fizeram necessárias.

A terceira etapa foi um breve resumo dos principais estudos e pesquisas desenvolvidos BOUERI, J.J., no campo do dimensionamento habitacional, também utilizadas na avaliação dimensional no capítulo III. 


\section{Capítulo III}

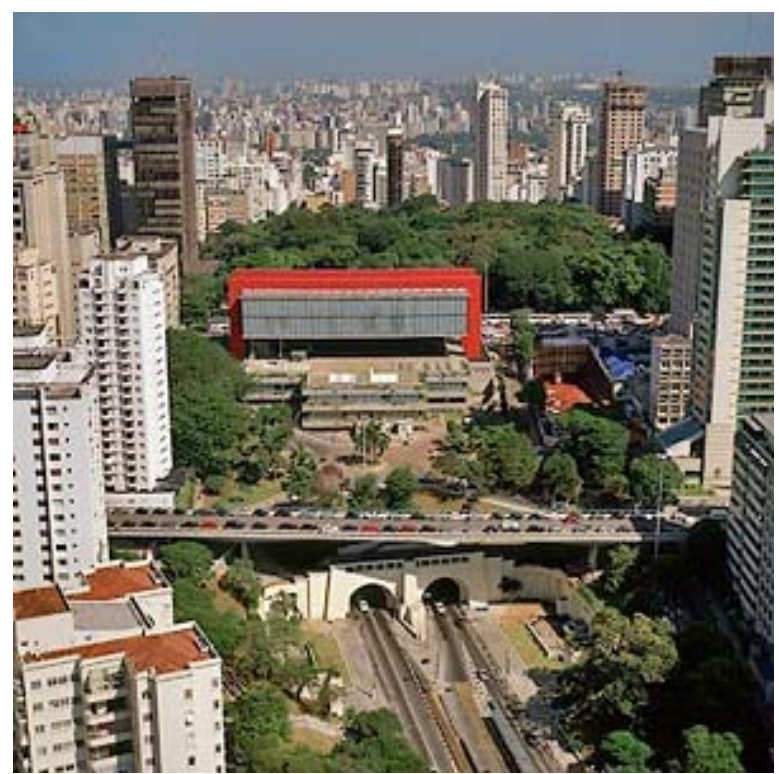

Fonte arq 057_02_02 arquitestos 20057 http:Iwww.vitruvius.com.br 
Capitulo III

\section{A Aplicação de Métodos de Qualidade Residencial em Empreendimentos do Mercado Imobiliário na Cidade de São Paulo}

As mudanças nos hábitos e comportamentos da vida contemporânea podem ser consideradas uma realidade,

... estudiosos de diferentes
horizontes têm apostado na mesma direção quando o
assunto é a metrópole do século XXI: seu habitante
parece ser um indivíduo que vive principalmente, sozinho,
que se agrupa eventualmente em formatos familiares
diversos, que se comunica a distância com as redes às
quais pertence, que trabalha em casa mas exige
equipamentos públicos para o encontro com o outro, que
busca sua identidade através do contato com a
informação."

Faz-se necessária uma revisão bibliográfica das convenções espaciais, visando atender as novas formas de ocupar o espaço doméstico. O trabalho em casa e a busca pela privacidade, entre outros, podem ser fatos geradores de uma maior compartimentação nas habitações. Como o mercado consumidor suporta até um determinado valor para a aquisição de imóveis, a saída encontrada é a alteração, para menor, na dimensão dos compartimentos.

Este capítulo, visa identificar onde e o que acontece com a qualidade habitacional dimensional dos compartimentos de apartamentos lançados de 2000 a 2005, na cidade de São Paulo. As plantas utilizadas

\footnotetext{
${ }^{1}$ Texto NOMAD'S

http:www.eesc.sc.ups.br/nomads/livraria_artigos_online_habitos_habitantes.htm 27/01/03
} 
foram retiradas do universo utilizado pelo "Inventário das Recomendações Dimensionais dos Espaços, Equipamentos e Mobiliário" 2.

"O método de Avaliação visa constituir um instrumento de apoio para os interventores em processos de decisão relacionados com a habitação". ${ }^{3}$

\section{Etapas para Aplicação do Método de Qualidade Residencial de} PEDRO, J.B. ${ }^{4}$

Esta etapa visa demonstrar os parâmetros adotados para a aplicação do Método de Avaliação de Qualidade Habitacional, classificado como "Exigência de Uso" (vide capítulo II páginas 13 e 14).

\subsection{Definição do Problema}

Após o levantamento realizado na pesquisa "Inventário das Recomendações Dimensionais dos Espaços, Equipamentos e Mobiliário", e o aprofundamento da pesquisa em habitações de 4 dormitórios, devido a maior gama de ambientes a serem estudados e conseqüente menor superposição de atividades, nesta etapa foi detectada grande variação de área na tipologia "4 dormitórios", fato que indicou a aplicação do método de qualidade habitacional para avaliar estas habitações.O motivo da escolha do MÉTODO foi a proximidade das linhas de pesquisa, como já citado no Capítulo II desta dissertação e a similaridade na forma de avaliar a funcionalidade através dos "Espaços de Atividades" 5 .

\footnotetext{
${ }^{2}$ FAPESP 03/09.069-1, 2004 BOUERI J.J., Inventário das Recomendações Dimensionais dos Espaços, Equipamentos e Mobiliário ${ }^{2}$, de agora em diante o texto irá utilizar apenas Inventário BOUERI FAPESP, quando fizer referencia a esta pesquisa.

${ }^{3}$ PEDRO , J.B 2003 pág. 287 Definição e Avaliação da Qualidade Arquitetônica Habitacional, Tese de Doutorado LNEC, Cidade do Porto, Portugal.

${ }^{4}$ Toda vez que for citado o MÉTODO, leia-se "Método de Avaliação de Qualidade Habitacional formulado pelo Dr. PEDRO, J.B." 2003

5 BOUERI, J. Jorge 2004 - A Contribuição da Ergonomia na Formação do Arquiteto - Tese de Livre Docência - São Paulo, FAU USP.
} 
O trabalhou teve inicio com a aplicação do método de qualidade habitacional nos apartamentos de 4 dormitórios, focando o trecho da árvore de pontos de vista nas exigências de uso, pois as informações obtidas dos empreendimentos não permitiam uma avaliação global, conforme proposta no MÉTODO, que propicia a análise individual de cada ponto de vista. Foram utilizados apenas os pontos de vista da linha de pesquisa adotada pelo grupo de pesquisa do Inventário BOUERI FAPESP. Dentro da amostragem existente, por solicitação do Dr. PEDRO,J.B., a aplicação foi realizada em 10 apartamentos de dentro de uma faixa de área privativa de $140,00 \mathrm{~m}^{2}$ para menos.

Após a conclusão destes 10 empreendimentos iniciais, se fez necessária a sua comparação com as demais tipologias, os Valores de Desempenho obtidos, nem sempre acompanhavam a variação de área privativa, surgindo a questão de como se comportariam as tipologias T3 e T2 que possuem área ainda menor. Foram escolhidos mais 10 empreendimentos sendo 5 de 3 dormitórios e 5 de 2 dormitórios, pertencentes também ao universo do mercado imobiliário, focando construtores e incorporadores com tradição na cidade de São Paulo.

Para a avaliação de um empreendimento o Dr. Pedro J.B., utiliza três indicadores:

as vizinhanças próximas, os edifícios e as habitações (unidade habitacional), cada um destes elementos trabalha com 5 indicadores:

1. Geometria

2. Conforto Ambiental

3. Segurança

4. Espaço Funcional

5. Articulação

6. Personalização 


\subsection{Identificação dos Atores}

Os atores são todas as pessoas ou entidades que influenciam na tomada de decisão do processo de desenvolvimento das unidades habitacionais. Este processo compreende desde a criação (arquiteto) até o usuário final passando pelos construtores e os agentes financeiros. Para a aplicação utilizamos 2 pessoas do grupo de pesquisa, O manual Técnico da Caixa Econômica Federal e como representante dos moradores e incorporadores as informações constantes no Inventário BOUERI FAPESP.

\subsection{Aferição dos Objetivos}

Quando a árvore dos pontos de vista adotada, é descrita e aprovada pelos atores. No caso em questão, o trecho de árvore foi escolhido pelo Dr. PEDRO, J.B., como já citado, e aprovada pelo grupo de pesquisa.

\subsection{Identificação das Soluções}

A identificação das soluções é quando os atores verificam se os elementos de avaliação descrevem e representam o desempenho das soluções segundo os objetivos definidos.

\section{Exemplo:}

\section{Objetivo:}

As habitações deverão suportar programas de ambientes de acordo com o número de usuários e suas necessidades.

Elementos de Avaliação

Espaços de Higiene Pessoal

Pontos

- A habitação possui mais de 1 banheiro 3

- A habitação possui 1 banheiro com ventilação natural 2

- A habitação possui uma instalação sanitária com ventilação indireta ou através de outro ambiente 


\subsection{Aferição dos Critérios de Avaliação}

A aferição dos critérios de avaliação é quando os atores verificam se os critérios de avaliação adotados são adequados, ou se devem proceder alguma alteração.

Exemplo: Utilizando o exemplo anterior, o banheiro talvez não necessite de ventilação natural.

\subsection{Verificação dos Critérios de Ponderação}

Nesta fase os atores verificam se a ponderação sugerida no método atende as suas necessidades, caso contrário deverá ser proposto novo critério de ponderação.

\section{Exemplo:}

Acompanhando o exemplo proposto, os atores verificariam se, os pontos obtidos pela habitação com mais de 1 banheiro, nos apartamentos de 2 dormitórios, representam a importância que eles desejavam para o fato ou não, caso contrário a ponderação deverá ser maior ou menor para este item.

\subsection{Avaliação dos Pontos de Vista Elementares}

Nesta fase são respondidas as perguntas de itens aos quais não se conseguiu delegar valores numéricos.Como estamos escolhendo alguns elementos de avaliação, não será utilizada esta etapa do método.

\subsection{Aplicação do Método de Síntese dos Resultados}

Nesta fase são calculados os Valores e Desempenho para cada empreendimento, já unindo e ponderando todos os pontos de vista, enfim é quando cada solução terá uma "nota" pode-se assim dizer.

\subsection{Análise dos Resultados}

Nesta fase os valores são apresentados para "os descritores", são as pessoas ou entidades responsáveis por tomar a decisão, caso tenhamos outras 
informações como o custo de cada opção, pode-se montar um gráfico da qualidade arquitetônica x custo. Desta análise podem resultar 3 opções:

1. tomar uma decisão baseada nos resultados da avaliação.

2. Considerar que nenhuma das soluções atinge os valores de desempenho desejados e portanto proceder as reformulações, nos empreendimentos.

3. considerar que o Método de Avaliação não traduz a apreciação dos atores, portanto proceder a as alterações necessárias e reaplicar o Método.

\section{A Arvore dos Pontos de Vista Utilizada}

A pesquisa se limita a Unidade Habitacional e dentro dela a Adequação Espaço Funcional. Assim, de acordo com a árvore hierárquica do MÉTODO utilizado $^{6}$, foi selecionado o um grupo de qualidade e dentro dele os seguintes pontos de vista:

Exigências de Uso (grupo de Qualidade)

Capacidade

Programa de Ambientes

Programa de Equipamentos

Espaciosidade

Área Útil

Dimensão Útil

Funcionalidade

\subsection{Exigências de Uso}

Dentro deste grupo de qualidades, vamos definir o que foi considerado como elementos de avaliação, critério de avaliação e ponderação em cada um deles.

\footnotetext{
${ }^{6}$ vide página 6 do Capítulo II, desta dissertação.
} 


\subsubsection{Capacidade}

\subsubsection{Definição dos Programas de Ambientes}

Os programas básicos de ambientes foram retirados do Conjunto de Funções de Uso, feito em conjunto, pelo Prof. Dr. Boueri,J.J. e pelo Dr. PEDRO, J.B., vide anexo 8 e as informações contidas no Inventário BOUERI FAPESP.

\section{Objetivo:}

As habitações devem ter programas de ambientes capazes de comportar a sua adequada utilização de acordo com o numero de usuários, que comporta ${ }^{7}$.

a. Identificação e Classificação dos Usuários

Como o universo estudado pertence ao mercado imobiliário, os usuários são indefinidos, apenas foi designada a lotação das habitações através do número de camas representadas nos desenhos de vendas.

b. Classificação dos Ambientes

Os ambientes foram classificados por zonas de uso residencial, a saber: Zona íntima, Zona de serviços, Zonas de circulação, Zona social, utilizando-se as funções de uso. Exemplo - descanso e dormir = Dormitórios= Zona Íntima ,dentro da amostra da pesquisa é a zona de maior concentração de área. A nomenclatura dos ambientes é a de senso comum, conforme indicado no método e seguindo o item 1.1 b. do Capítulo III.

c. Identificação das Funções e Atividades

As funções de uso, seguem as definidas no Capítulo II (vide anexo 3)

1. descanso pessoal

2. preparação de refeições

3. refeições

4. estar

5. atividades das crianças

6. atividades dos jovens

7. atividades de adultos

8. tratamento de roupa

9. higiene pessoal

10. manutenção / arrumação da casa

\footnotetext{
${ }^{7}$ Página 130, idem 1
} 
11. permanência no exterior privado

12. estacionamento de veículos

\section{d. Tipologia}

A tipologia adotada foi a mesma do MÉTODO, tendo a nomenclatura associada ao número de dormitórios,com já citado no capítulo II, quais sejam:

T1 - Habitações de 1 dormitório

T2 - Habitações de 2 dormitórios

T3 - Habitações de 3 dormitórios

T4 - Habitações de 4 dormitórios

Para a definição dos elementos de avaliação foram adotados 3 Programas de Ambientes distintos, um por Tipologia, retirados da amostra estudada no Inventário BOUERI FAPESP, da seguinte forma; o nome dos ambientes vem associado a uma porcentagem nas tabelas ${ }^{8}$ que indicada a incidência destes ambientes, encontrada dentro da amostra estudada. Os ambientes foram definidos pelo mobiliário representado nas peças publicitárias. Apesar do Método utilizado trabalhar com apenas um conjunto de perguntas, foi feita uma adaptação devido a grande variedade de ambientes encontrada de uma tipologia para outra na cidade de São Paulo. A tipologia T1 não teve suas plantas avaliadas neste trabalho, por não se caracterizarem como habitações tipicamente familiares.

Tabela 1 .Programa de Ambientes para Apartamentos de 2 Dormitórios T2

\begin{tabular}{|l|r|}
\hline AMBIENTES & $\%$ \\
\hline Dormitório Casal & 100,00 \\
\hline Dormitório Solteiro Duplo & 100,00 \\
\hline Sala de Estar e Jantar & 100,00 \\
\hline Banheiro Social & 100,00 \\
\hline Cozinha & 63,63 \\
\hline Copa-Cozinha & 36,36 \\
\hline Área de Serviço & 100,00 \\
\hline Dependências de Serviço & 3,64 \\
\hline Varandas & 89,09 \\
\hline Estacionamento & 100,00 \\
\hline
\end{tabular}

As vagas para estacionamento: $27,27 \%$ dos empreendimentos com: 1 ou 2 vagas,

$21,82 \%$ com 2 vagas e $36,36 \%$ não informam

${ }^{8}$ vide anexo 2 
Tabela 2 Programa de Ambientes para Apartamentos de 3 dormitórios T3

\begin{tabular}{|l|r|}
\hline AMBIENTES & \multicolumn{1}{|c|}{$\%$} \\
\hline Dormitório Casal & 14,10 \\
\hline Dormitório de Casal Suíte $^{\star}$ & 85,90 \\
\hline Dormitório de Solteiro Individual & 03,60 \\
\hline Dormitório Solteiro Duplo & 61,59 \\
\hline S. de Estar e Jantar Conjugadas & 96,50 \\
\hline Banheiro Social & 100,00 \\
\hline Lavabo & 29,04 \\
\hline Cozinha & 38,83 \\
\hline Copa-Cozinha & 61,17 \\
\hline Dependências de Serviço & 40,80 \\
\hline Banheiro de Serviço & 63,50 \\
\hline Área de Serviço & 100,00 \\
\hline Varandas & 98,80 \\
\hline Depósito em subsolo & 18,82 \\
\hline Estacionamento & 100,00 \\
\hline
\end{tabular}

* denominação dada a dormitório com banheiro de uso privativo.

** foram consideradas também dependências de serviço os chamados "dormitórios reversíveis"

As vagas para estacionamento de veículos, foram assim identificadas:

$27,27 \%$ dos empreendimentos com 1 ou

2 vagas,

$21,82 \%$ com 2 vagas e

$36,36 \%$ não informam

Tabela 3 Programa de Ambientes para Apartamentos de 4 dormitórios T4

\begin{tabular}{|l|r|}
\hline AMBIENTES & \multicolumn{1}{|c|}{$\%$} \\
\hline Dormitório Casal Suíte Principal & 100,00 \\
\hline Closet & 82,20 \\
\hline Dormitório de Solteiro Individual & 40,50 \\
\hline Dormitório Solteiro Duplo & 59,50 \\
\hline Ambientes Extras & 38,70 \\
\hline Sala de Famíla/TV & 27,40 \\
\hline Sala de Estar e Jantar Conjugadas & 72,50 \\
\hline Sala de Jantar Separada & 22,60 \\
\hline Banheiro Social & 79,00 \\
\hline Lavabo & 41,90 \\
\hline Sala de Almoço & 22,58 \\
\hline Cozinha & 58,01 \\
\hline Copa-Cozinha & 100,00 \\
\hline Dependências de Serviço** & 100,00 \\
\hline Despensa & 38,70 \\
\hline Banheiro de Serviço & 100,00 \\
\hline Área de Serviço & 100,00 \\
\hline Varandas & 100,00 \\
\hline Deposito em Subsolo & 22,58 \\
\hline Estacionamento & 100,00 \\
\hline
\end{tabular}

*denominação dada a dormitório com banheiro de uso privativo.

** foram consideradas as dependências de serviço : os chamados "dormitórios reversíveis" e os "dormitórios de empregada"(ambientes inseridos na zona de serviços, sem denominação específica como os sanitários e as despensas de alimentos ou material de limpeza).

*** Ambientes Extras formam identificados como ambientes extras, aqueles que podem ser excluídos sem descaracterizar a tipologia, tais como; as Sala de Família,os Home Theatre, as Sala de TV, os Home Office e escritórios (vide trabalho programado do autor) 


\subsection{Elementos de Avaliação Programa de Ambientes}

\section{Programa de Ambientes T2}

Para apartamentos de 2 Dormitórios a lotação utilizada para aplicação do Método foi a mesma utilizada na Pesquisa do Mercado Imobiliário ou seja, o número de moradores é igual ao número de camas indicadas nos desenhos e vendas.

\section{Objetivo:}

As habitações deverão suportar programas de ambientes de acordo com o número de usuários e suas necessidades. Os elementos de avaliação utilizados, tiveram como base a Pesquisa do Mercado Imobiliário, realizada pelo Prof. Dr. J. Boueri em 2004.Vide programa de ambientes em anexo. A lotação é verificada pelo número de camas indicadas nos desenhos.

\section{Estar / Reunir/ Jantar e Receber}

A A habitação contém ambiente de sala que comporta 3 atividades- receber, estar, e fazer refeições para todos os moradores mais uma pessoa

B A habitação contém ambiente de sala que comporta as 3 atividades- receber, estar e fazer refeições, apenas para os moradores

C Nenhuma das condições anteriores

2. Dependências de Serviços

A Dormitório de Serviço - (+ de $\left.5 \mathrm{~m}^{2}\right)$ condição brasileira

B A habitação possui ambiente de circulação que comporta uma cama, ou ambiente com menos de $5 \mathrm{~m}^{2}$ que comporta uma cama

C A Habitação não contem tal espaço

\section{Espaços de Higiene Pessoal}

A A habitação possui mais de 1 banheiro 3

B A habitação possui 1 banheiro com ventilação natural

C A habitação possui uma instalação sanitária com ventilação indireta ou através de outro ambiente

\section{Espaço para Arrumação}

A A habitação contém despensa ou depósito no pavimento ou em área de uso comum. 3

B A habitação possui espaço para roupeiro nas áreas de circulação ou closet. 2

C Nenhuma das condições anteriores é satisfeita. 
Programa de Ambientes 2 Dormitórios - (continuação)

\section{Espaços de Tratamento de Roupa}

A A habitação contém área de serviço em ambiente isolado com acesso independente.

B A habitação contém área de serviço em espaço contíguo a cozinha, mas em outro ambiente (nota 1)

C A habitação contém área de serviço no mesmo ambiente da cozinha.

\section{Espaço de Refeições Correntes / Copa/Cozinha}

A A habitação contém um espaço para refeições informais dentro cozinha, que não se sobrepõe aos espaços de atividade dos demais equipamentos.

B A habitação contém um espaço de refeições na cozinha que se sobrepõe aos espaços de atividade dos demais equipamentos .

C A habitação não comporta espaço para refeições informais.

\section{Espaços Exteriores Privados/ Varandas}

A A habitação possui varanda que comporta o exercício de uma atividade com equipamentos.

B A habitação possui varanda que comporta uma atividade sem equipamentos

C A habitação não possui varanda.

\section{Espaços para Estacionamento}

A A habitação possui mais de 1 vaga para estacionamento em subsolo

B A habitação possui 1 vaga para estacionamento em subsolo ou não simples

C A habitação possui 1 vaga para estacionamento com uso de manobrista

\section{Notas:}

1. a cozinha tem ventilação independente da área de serviço

2. quando depararmos com o título "suíte americanas" considerar apenas 1 banheiro. 
Programa de Ambientes T3

1.Estar / Reunir/ Jantar e Receber

A A Habitação contém um ambiente de sala que comporta todos os moradores mais uma pessoa nas duas salas - estar e jantar?

B A Habitação contém uma sala de estar e jantar em um só ambiente que comporta o número de moradores

C Nenhuma das condições anteriores

2.Dependências de Serviços

A Dormitório de Serviço - (+ de $\left.5 \mathrm{~m}^{2}\right)$ condição brasileira

B A habitação possui ambiente de circulação que comporta uma cama, ou ambiente com menos de $5 \mathrm{~m}^{2}$ que comporta uma cama

C A Habitação não contem tal espaço

\section{Espaços de Higiene Pessoal}

A A habitação possui mais de 3 banheiros 3

B A habitação possui 2 banheiros- sociais e do casal 2

C A habitação possui apenas 1 instalação sanitária 1

\section{Espaço para Arrumação}

A A habitação contém despensa ou depósito no pavimento ou em área de uso comum?

B A habitação possui espaço para roupeiro nas áreas de circulação 2

C Nenhuma das condições anteriores é satisfeita $\quad 1$

5.Espaços de Tratamento de Roupa

A A Habitação contem área de serviço com acesso independente 3

B A Habitação contem área de serviço com acesso somente pela cozinha 2

C A Habitação contém apenas espaço para tanque e 1 máquina em uso contíguo a cozinha 


\section{Programa de Ambientes 3 Dormitórios - (continuação)}

\section{Espaço de Refeições Correntes / Copa}
A A Habitação contém um espaço para refeições informais dentro ou fora das cozinhas, que não se sobrepõe aos espaços de atividade dos demais equipamentos.
B A habitação contém um espaço de refeições integrado na cozinha
C Nenhuma das condições anteriores.

\section{Espaços Exteriores Privados/Varandas}
A A habitação possui varanda que comporta o exercício de mais de uma atividade ao mesmo tempo.
B A habitação possui varanda que comporta uma atividade sem equipamentos. 2
C A habitação não possui varanda.

\section{Espaços para Estacionamento}
A A habitação possui 2 ou mais 3 vagas para estacionamento em subsolo. 3
B A habitação possui 2 vagas para estacionamento em subsolo ou não. 2
C A habitação possui 1 vaga para estacionamento coberta ou descoberta. 1

\section{Programas de Ambientes T4}

\section{Estar / Reunir/ Jantar e Receber}

A A Habitação contém mais de um ambiente de sala que comporte todos os moradores abrigando as atividades de estar receber refeições formais + lazer?

B A Habitação contém uma sala de uso comum que comporte 3 atividades distintas para todos os moradores +1 pessoa

C Nenhuma das condições anteriores

\section{Dependências de Serviços}

A Dormitório de Serviço - $\left(+\right.$ de $\left.5 \mathrm{~m}^{2}\right)$ condição brasileira

B A habitação possui ambiente de circulação que comporta uma cama, ou ambiente com menos de $5 \mathrm{~m}^{2}$ que comporta uma cama 2

C A Habitação não contem tal espaço 


\section{Programa de Ambientes T4-(continuação)}

\section{Espaços de Higiêne Pessoal}

$\begin{array}{llr}\text { A } & \text { A habitação possui mais de } 3 \text { banheiros ? } & 3 \\ \text { B } & \text { A habitação possui lavabo ou outra suíte } & 2 \\ \text { C } & \text { A habitação possui apenas 2 instalações sanitárias (social e casal) } & 1\end{array}$

\section{Espaço para Arrumação}
A A habitação contém Despensa + Closet.+ Deposito em subsolo
B Closet ou despensa ou roupeiro, ou dep. Em subsolo
C Nenhuma das condições anteriores é satisfeita

\section{Espacos de Tratamento de Roupa}

A A Habitação contem área de serviço com acesso independente 3

B A Habitação contem área de serviço com acesso somente pela cozinha 2

C A Habitação contém apenas espaço para tanque e 1 máquina em uso contíguo a cozinha

1

\section{Espaço de Refeiç̃oes Correntes / Copa}

A A Habitação contém uma copa ou sala de almoço, que não se sobrepõe ao espaço de refeições formais.

B A habitação contém um espaço de refeições informais integrado na cozinha sem sobreposição de espaços de atividade

C Nenhuma das condições anteriores

\section{Espaços Exteriores Privados/Varandas}

A A habitação possui varanda que comporta o exercício de 3 ou mais atividades ao mesmo tempo. Ex. / fazer churrasco / estar/ apreciar

B A habitação possui varanda que comporta duas atividades de lazer com equipamentos .

C A habitação não possui varanda, ou possui com $\varnothing$ menor que $0,90 \mathrm{~m}$

\section{Espaços para Estacionamento}
A A habitação possui mais de 3 ou mais vagas para estacionamento em subsolo
B A habitação possui 2 ou 3 vagas para estacionamento em subsolo
C A habitação possui 2 vagas para estacionamento cobertas ou descobertas 
2.1.1.1.2. Critérios de Avaliação Programas de Ambientes

Gráfico 1-Critério adotado para a avaliação de Programas- Fonte METODO

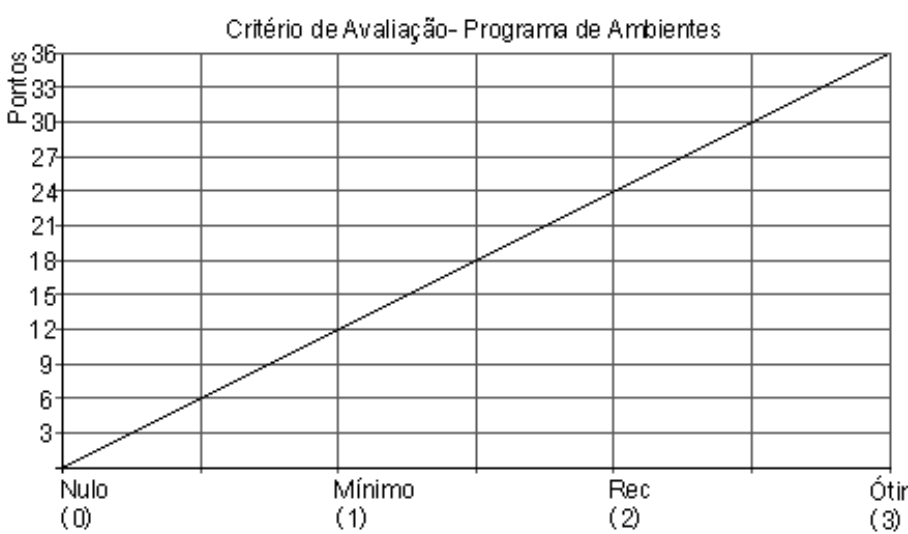

O critério de avaliação para o programa de ambientes segue a definição dos níveis de qualidade (vide item 1.2.2 do capítulo II). O gráfico adotado segue 0 Método, apenas teve o movalor máximo alterado de 33 para 36 pontos, compatibilizando-0 com a ponderação adotada.

Tabela 4 Ponderação Programas de Ambientes - Fonte autor

\begin{tabular}{|c|c|c|c|}
\hline Questões & Adotada & $\begin{array}{c}\text { Valor } \\
\text { Máximo }\end{array}$ & $\begin{array}{c}\text { Sugerida } \\
\text { /Método }\end{array}$ \\
\hline 1 & 2 & 6 & 1 \\
\hline 2 & 1 & 3 & - \\
\hline 3 & 2 & 6 & 2 \\
\hline 4 & 1 & 3 & 1 \\
\hline 5 & 1 & 3 & 2 \\
\hline 6 & 1 & 3 & 1 \\
\hline 7 & 2 & 6 & 1 \\
\hline 8 & 2 & 6 & 2 \\
\hline Total & & 36 & 33 \\
\hline
\end{tabular}

Esta é a ponderação adotada para a avaliação do programa de ambientes, para todas as tipologias. As alterações em relação a tabela do método, foram definidas pelos atores. Ex. A arrecadação (acesso) foi substituída por dependências de serviço, ambientes menos usuais em

Tabela 5- Valor de Desempenho Programa de Ambientes - Fonte METODO

\begin{tabular}{|c|c|c|}
\hline & Pontos & Valor de Desemp. \\
\hline Mínimo & 12 & 1 \\
\hline Recomendável & 24 & 2 \\
\hline Ótimo & 36 & 3 \\
\hline
\end{tabular}


2.1.1.1.2.Resultado da Avaliação do Programa de Ambientes nas tipologias de 2, 3 e 4 dormitórios.

Tabela 6- Resumo da Avaliação Programas de Ambientes T2

\begin{tabular}{|c|c|c|c|c|c|c|c|c|c|c|c|}
\hline \multicolumn{2}{|c|}{ Empreendimentos } & \multicolumn{2}{|c|}{1} & \multicolumn{2}{|c|}{2} & \multicolumn{2}{|c|}{3} & \multicolumn{2}{|c|}{4} & \multicolumn{2}{|c|}{5} \\
\hline $\begin{array}{c}\text { Pontos de } \\
\text { Vista }\end{array}$ & Pond. & Ptos & $\begin{array}{l}\text { Ptos } x \\
\text { Pond. }\end{array}$ & Ptos & $\begin{array}{l}\text { Ptos } x \\
\text { Pond. }\end{array}$ & Ptos & $\begin{array}{l}\text { Ptos } x \\
\text { Pond. }\end{array}$ & Ptos & $\begin{array}{l}\text { Ptos } x \\
\text { Pond. }\end{array}$ & Ptos & $\begin{array}{l}\text { Ptosx } \\
\text { Pond. }\end{array}$ \\
\hline 1 & 2 & 1 & 2 & 1 & 2 & 1 & 2 & 2 & 4 & 2 & 4 \\
\hline 2 & 1 & 2 & 2 & 2 & 2 & 1 & 1 & 3 & 3 & 2 & 2 \\
\hline 3 & 2 & 1 & 2 & 1 & 2 & 1 & 2 & 2 & 4 & 1 & 2 \\
\hline 4 & 1 & 1 & 1 & 1 & 1 & 1 & 1 & 2 & 2 & 1 & 1 \\
\hline 5 & 1 & 1 & 1 & 2 & 2 & 1 & 1 & 1 & 1 & 1 & 1 \\
\hline 6 & 1 & 3 & 3 & 1 & 1 & 1 & 1 & 1 & 1 & 1 & 1 \\
\hline 7 & 2 & 3 & 6 & 1 & 2 & 1 & 2 & 3 & 6 & 1 & 2 \\
\hline 8 & 2 & 1 & 2 & 1 & 2 & 1 & 2 & 3 & 6 & 1 & 2 \\
\hline \multicolumn{2}{|l|}{ Somatória } & & 19 & & 14 & & 12 & & 27 & & 15 \\
\hline \multicolumn{2}{|c|}{ V. de Desempenho } & \multicolumn{2}{|c|}{1,58} & \multicolumn{2}{|c|}{1,17} & \multicolumn{2}{|c|}{1,00} & \multicolumn{2}{|c|}{2,25} & \multicolumn{2}{|c|}{1,25} \\
\hline
\end{tabular}

Tabela 7- Resumo da Avaliação Programas de Ambientes T3

\begin{tabular}{|c|c|c|c|c|c|c|c|c|c|c|c|}
\hline \multicolumn{2}{|c|}{ Empreendimentos } & \multicolumn{2}{|c|}{1} & \multicolumn{2}{|c|}{2} & \multicolumn{2}{|c|}{3} & \multicolumn{2}{|c|}{4} & \multicolumn{2}{|c|}{5} \\
\hline & & \multirow[t]{2}{*}{ Ptos } & \multirow{2}{*}{$\begin{array}{l}\text { Ptos X } \\
\text { Pond. }\end{array}$} & \multirow[t]{2}{*}{ Ptos } & \multirow{2}{*}{$\begin{array}{l}\text { Ptos } \mathrm{x} \\
\text { Pond. }\end{array}$} & \multirow{2}{*}{ Ptos } & \multirow{2}{*}{$\begin{array}{r}\text { Ptos } x \\
\text { Pond. }\end{array}$} & \multirow[t]{2}{*}{ Ptos } & \multirow{2}{*}{$\begin{array}{l}\text { Ptos X } \\
\text { Pond. }\end{array}$} & \multirow[t]{2}{*}{ Ptos } & \multirow{2}{*}{$\begin{array}{l}\text { Ptos } \mathrm{x} \\
\text { Pond. }\end{array}$} \\
\hline $\begin{array}{l}\text { Pontos de } \\
\text { Vista }\end{array}$ & Pond. & & & & & & & & & & \\
\hline 1 & 2 & 2 & 4 & 2 & 4 & 1 & 2 & 2 & 4 & 2 & 4 \\
\hline 2 & 1 & 2 & 2 & 1 & 1 & 2 & 1 & 2 & 2 & 1 & 1 \\
\hline 3 & 2 & 3 & 6 & 1 & 2 & 3 & 2 & 3 & 6 & 1 & 2 \\
\hline 4 & 1 & 1 & 1 & 1 & 1 & 4 & 1 & 1 & 1 & 1 & 1 \\
\hline 5 & 1 & 3 & 3 & 1 & 1 & 5 & 1 & 3 & 3 & 1 & 1 \\
\hline 6 & 1 & 3 & 3 & 1 & 1 & 6 & 1 & 3 & 3 & 1 & 1 \\
\hline 7 & 2 & 2 & 4 & 1 & 2 & 7 & 2 & 2 & 4 & 1 & 2 \\
\hline 8 & 2 & 2 & 4 & 1 & 2 & 8 & 2 & 2 & 4 & 1 & 2 \\
\hline \multicolumn{2}{|l|}{ Somatória } & & 27 & & 14 & & 12 & & 27 & & 14 \\
\hline \multicolumn{2}{|c|}{ V. de Desempenho } & \multicolumn{2}{|c|}{2,25} & \multicolumn{2}{|c|}{1,17} & \multicolumn{2}{|c|}{2,08} & \multicolumn{2}{|c|}{2,25} & \multicolumn{2}{|c|}{1,25} \\
\hline
\end{tabular}


Tabela 8 Resumo da Avaliação Programas de Ambientes T4

\begin{tabular}{|c|c|c|c|c|c|c|c|c|c|c|c|}
\hline \multicolumn{2}{|c|}{ Empreendimentos } & \multicolumn{2}{|c|}{7} & \multicolumn{2}{|c|}{12} & \multicolumn{2}{|c|}{18} & \multicolumn{2}{|c|}{19} & \multicolumn{2}{|c|}{49} \\
\hline & & \multirow[t]{2}{*}{ Pontos } & \multirow{2}{*}{$\begin{array}{l}\text { Ptos } \mathrm{x} \\
\text { Pond. }\end{array}$} & \multirow[t]{2}{*}{ Pontos } & \multirow{2}{*}{$\begin{array}{l}\text { Ptos } x \\
\text { Pond. }\end{array}$} & \multirow[t]{2}{*}{ Pontos } & \multirow{2}{*}{$\begin{array}{l}\text { Ptos } \mathrm{x} \\
\text { Pond. }\end{array}$} & \multirow[t]{2}{*}{ Pontos } & \multirow{2}{*}{$\begin{array}{l}\text { Ptos } x \\
\text { Pond. }\end{array}$} & \multirow[t]{2}{*}{ Pontos } & \multirow{2}{*}{$\begin{array}{l}\text { Ptos } x \\
\text { Pond. }\end{array}$} \\
\hline P. de Vista & Pond. & & & & & & & & & & \\
\hline 1 & 2 & 3 & 6 & 2 & 4 & 2 & 4 & 3 & 6 & 3 & 6 \\
\hline 2 & 1 & 2 & 2 & 2 & 2 & 2 & 2 & 1 & 1 & 2 & 2 \\
\hline 3 & 2 & 3 & 6 & 3 & 6 & 2 & 4 & 1 & 2 & 1 & 2 \\
\hline 4 & 1 & 2 & 2 & 2 & 2 & 2 & 2 & 1 & 1 & 2 & 2 \\
\hline 5 & 1 & 2 & 2 & 3 & 3 & 3 & 3 & 1 & 1 & 2 & 2 \\
\hline 6 & 1 & 2 & 2 & 1 & 1 & 2 & 2 & 1 & 1 & 2 & 2 \\
\hline 7 & 2 & 3 & 6 & 3 & 6 & 2 & 4 & 2 & 4 & 2 & 4 \\
\hline 8 & 2 & 3 & 6 & 3 & 6 & 3 & 6 & 1 & 2 & 1 & 2 \\
\hline \multicolumn{2}{|l|}{ Somatória } & & 32 & & 30 & & 27 & & 18 & & 22 \\
\hline \multicolumn{2}{|c|}{ V. de Desempenho } & \multicolumn{2}{|c|}{2,67} & \multicolumn{2}{|c|}{2,50} & \multicolumn{2}{|c|}{2,25} & \multicolumn{2}{|c|}{1,50} & \multicolumn{2}{|c|}{1,83} \\
\hline
\end{tabular}

Tabela 8 (continuação)- Resumo da Avaliação Programas de Ambientes T4

\begin{tabular}{|c|c|c|c|c|c|c|c|c|c|c|c|}
\hline \multicolumn{2}{|c|}{ Empreendimentos } & \multicolumn{2}{|c|}{113} & \multicolumn{2}{|c|}{165} & \multicolumn{2}{|c|}{166} & \multicolumn{2}{|c|}{167} & \multicolumn{2}{|c|}{168} \\
\hline & & \multirow[t]{2}{*}{ Pontos } & \multirow{2}{*}{$\begin{array}{l}\text { Ptos } x \\
\text { Pond. }\end{array}$} & \multirow{2}{*}{ Pontos } & \multirow{2}{*}{$\begin{array}{l}\text { Ptos } x \\
\text { Pond. }\end{array}$} & \multirow{2}{*}{ Pontos } & \multirow{2}{*}{$\begin{array}{l}\text { Ptos } x \\
\text { Pond. }\end{array}$} & \multirow{2}{*}{ Pontos } & \multirow{2}{*}{$\begin{array}{l}\text { Ptos } x \\
\text { Pond. }\end{array}$} & \multirow{2}{*}{ Pontos } & \multirow{2}{*}{$\begin{array}{l}\text { Ptos } x \\
\text { Pond. }\end{array}$} \\
\hline P. de Vista & Pond. & & & & & & & & & & \\
\hline 1 & 2 & 3 & 6 & 3 & 6 & 2 & 4 & 2 & 4 & 3 & 6 \\
\hline 2 & 1 & 1 & 1 & 2 & 2 & 1 & 1 & 1 & 1 & 2 & 2 \\
\hline 3 & 2 & 3 & 6 & 2 & 4 & 2 & 4 & 3 & 6 & 3 & 6 \\
\hline 4 & 1 & 3 & 3 & 2 & 2 & 1 & 1 & 2 & 2 & 3 & 3 \\
\hline 5 & 1 & 3 & 3 & 1 & 1 & 3 & 3 & 3 & 3 & 1 & 1 \\
\hline 6 & 1 & 2 & 2 & 1 & 1 & 2 & 2 & 2 & 2 & 1 & 1 \\
\hline 7 & 2 & 2 & 4 & 2 & 4 & 2 & 4 & 3 & 6 & 3 & 6 \\
\hline 8 & 2 & 3 & 6 & 1 & 2 & 1 & 2 & 1 & 2 & 1 & 2 \\
\hline \multicolumn{2}{|l|}{ Somatória } & & 31 & & 22 & & 21 & & 26 & & 27 \\
\hline \multicolumn{2}{|c|}{ V. de Desempenho } & \multicolumn{2}{|c|}{2,58} & \multicolumn{2}{|c|}{1,83} & \multicolumn{2}{|c|}{1,75} & \multicolumn{2}{|c|}{2,17} & \multicolumn{2}{|c|}{2,25} \\
\hline
\end{tabular}


Gráfico 2- Variação dos Valores de Desempenho dos Programas de Ambientes de todos os Empreendimentos, por Tipologia

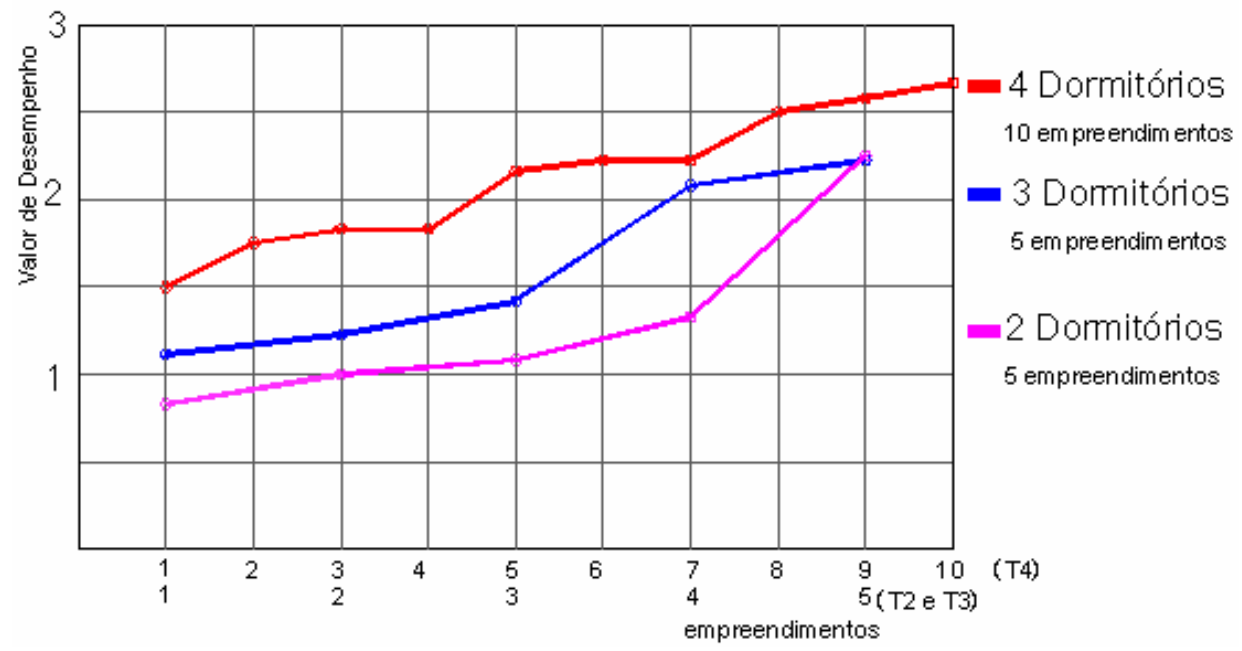

Gráfico 3 - Variação dos Valores de Desempenho dos Programas de Ambientes de todos os Empreendimentos , por Área Privativa

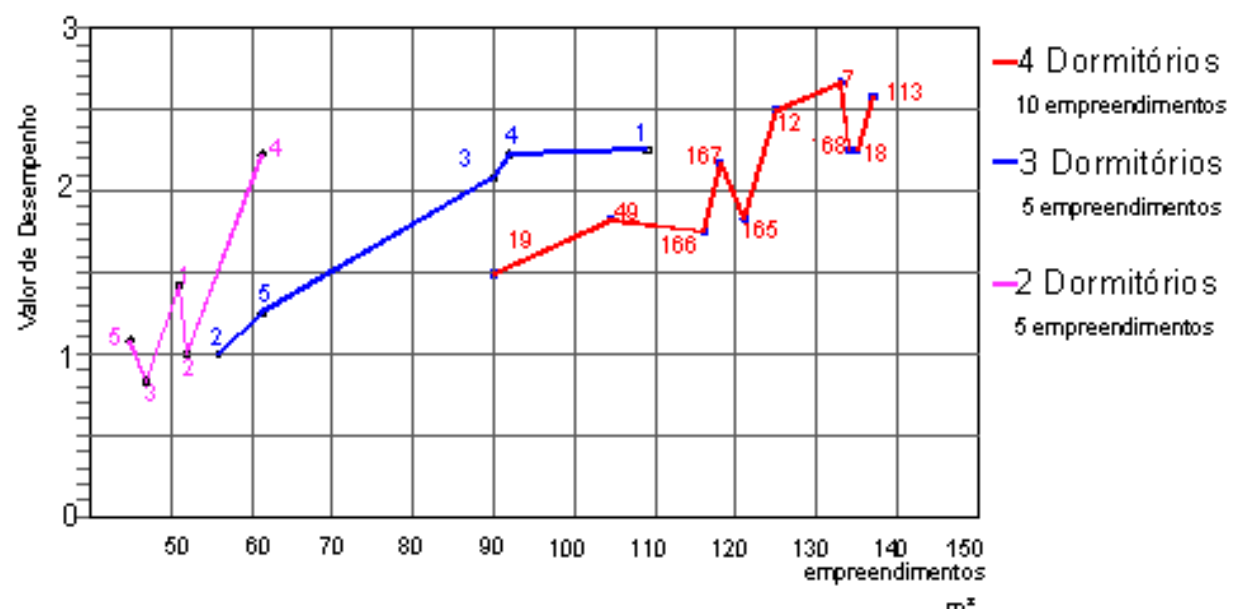


Imobiliário na Cidade de São Paulo 


\subsection{Análise dos Resultados dos Programas de Ambientes}

O perfil de qualidade representado pela evolução dos valores de desempenho dos programas de ambientes (Gráfico 2), nos mostra que a maior parte dos apartamentos de 2 dormitórios (T2) estão abaixo do nível recomendável, independentemente da área privativa que possuem.
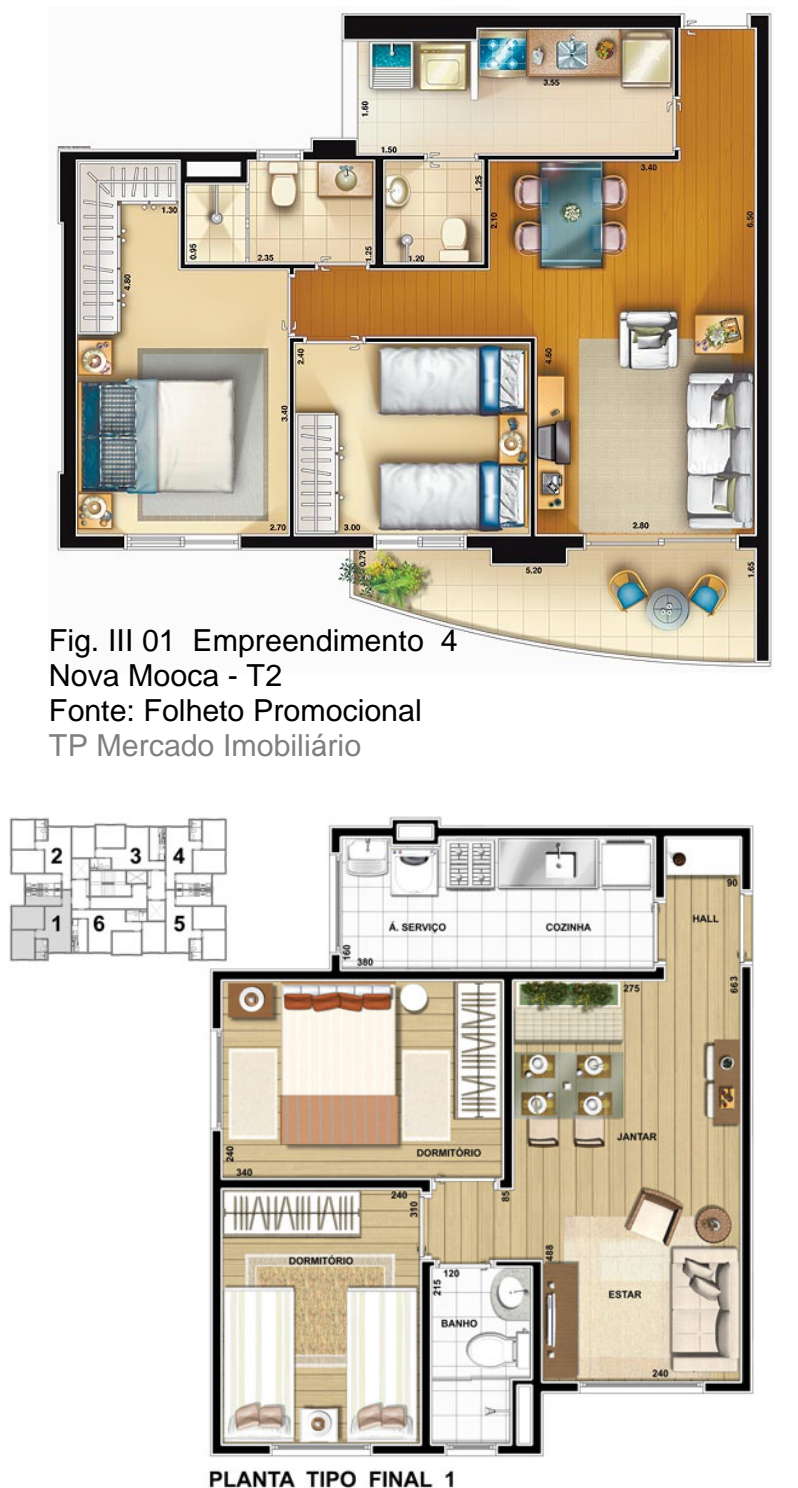

A planta 4, da figura 1 ao lado, se destaca da amostra com a maior área privativa. Obteve o valor de desempenho de 2,25 (acima do recomendável) quanto ao programa de ambientes, devido principalmente aos 2 banheiros e a varanda. Apesar de não suportar a atividade receber, na sala de estar e não possuir local para realizar refeições correntes na cozinha.

È importante ressaltar que a área privativa, da planta 4 está aproximadamente $\quad 20 \%$ acima das demais plantas estudadas, a figura ao lado, planta 5, obteve um valor de desempenho, para programa de ambientes de 1,25 (considerado mínimo).

O que indica que a ponderação adotada reflete uma relação entre o elemento avaliado e a área

Fig. III 02 Empreend. 5 Eco Vitta -finais 1,2,3 e 4 T2privativa.

Fonte: http://www.ecovittasabara.com.br/

http://www.ecovittasabara.com.br -Plantas finais 1,2,3 e 4

TP Mercado Imobiliário 
2.1.1.2. Definição dos Programas de Mobiliário e Equipamentos Mínimos por Tipologia

O mobiliário e os equipamentos foram selecionados para exercer as funções de uso e tiveram como base as informações constantes no item 2.3.1.2. do ITA / LNEC n5 (1999), Pedro, J.B., com adaptações retiradas do Inventário BOUERI FAPESP, (2004). Acessórios como abajur, e equipamentos que são apoiados sobre mobiliário, que não ocupam espaço em planta não foram listados.

Objetivo:

As Habitações devem comportar o mobiliário e os equipamentos (fixos ou móveis) de acordo com a tipologia e com o número proposto de usuários. As tabelas, 9,10, e 11 serviram de base para a formulação dos elementos de avaliação dos Programas ed Equipamentos e Mobiliário.

Tabela 9- Programa de Mob. e Equip. T2

Fonte- Trabalho Programado "Pesquisa de Composição de Ambientes, Mobiliário e Equipamentos da Habitação, 2004"9 do autor.

\begin{tabular}{|c|c|}
\hline Ambientes & Mobiliário e Equipamentos \\
\hline Dormitório Casal & $\begin{array}{l}1 \text { cama de casa } 1+2 \text { criados mudos } \\
4 \text { unidades de armário de } .60 \mathrm{~cm}^{10} \\
1 \text { cadeira }\end{array}$ \\
\hline Dormitório Solteiro Duplo & $\begin{array}{l}2 \text { camas de solteiro }+1 \text { criado mudo } \\
\text { mesa de estudo }+3 \text { unidades de armário }\end{array}$ \\
\hline $\begin{array}{l}\text { Sala de Estar e Jantar } \\
\text { conjugadas }\end{array}$ & $\begin{array}{l}\text { Sofás e poltronas (4assentos)+mesa de } \\
\text { centro+ estante tv+ } 1 \text { mesa lateral } \\
\text { Mesa para } 4 \text { pessoas +aparador }\end{array}$ \\
\hline Banheiro Social & Bacia+ lavatório+ chuveiro \\
\hline Cozinha & 1 fogão+ 1 geladeira+ 1 pia+armário+ MLL \\
\hline Copa-Cozinha & $\begin{array}{l}1 \text { fogão }+1 \text { geladeira }+ \text { pia }+ \text { MLL+ mesa ou } \\
\text { bancada com } 2 \text { assentos }\end{array}$ \\
\hline Área de Serviço & $\begin{array}{l}1 \text { tanque }+1 \text { MLR+ tábua de passar } \\
\text { +armário+ } 1 \text { varal de teto }\end{array}$ \\
\hline Despensa / rouparia & 1 armário de geral \\
\hline Varandas & Cadeiras \\
\hline Estacionamento & 1 vaga \\
\hline
\end{tabular}

\footnotetext{
${ }^{9}$ Este trabalho é parte integrante do Inventário FAPESP, e fonte também, para as demais tipologias, será citado daqui por diante como TP Mercado Imobiliário

10 mobiliário mínimo, vide página 89 ITA / LNEC n5, PEDRO,J.B. 1999, com adaptações
} 
Para a tipologia T2, foi utilizado também o Manual Técnico da Caixa Econômica Federal, como referencia.

Tabela 10- Programa de Mob. e Equip. T3 Fonte - TP- Mercado Imobiliário

\begin{tabular}{|c|c|}
\hline Ambientes & Funções \\
\hline Dormitório Casal & $\begin{array}{l}1 \text { cama de casal+2 criados mudos } \\
4 \text { unidades de armário de } 60 \mathrm{~cm}+1 \text { cadeira+ } \\
\text { estante para TV+ bancada ou mesa }\end{array}$ \\
\hline Dormitório de Casal Suíte* & $\begin{array}{l}1 \text { cama de casal+ } 2 \text { criados mudos } \\
4 \text { unidades de armário de } 60 \mathrm{~cm} \text { ou closet }+ \\
1 \text { cadeira+estante para TV }\end{array}$ \\
\hline Closet Dormitórios & 4 unidades de $60 \mathrm{~cm}$ de armários \\
\hline Dormitório de Solteiro Individual & $\begin{array}{l}1 \text { cama de solteiro }+1 \text { criado mudo } \\
\text { mesa de estudo }+2 \text { unidades de armário }\end{array}$ \\
\hline Dormitório Solteiro Duplo & $\begin{array}{l}2 \text { camas de solteiro }+1 \text { criado mudo } \\
\text { mesa de estudo } 3 \text { unidades de armário }\end{array}$ \\
\hline Sala de Estar e Jantar Conjugadas & $\begin{array}{l}\text { Sofás e poltronas ( } 6 \text { assentos)+mesa de centro+ } \\
\text { estante TV+1 mesa lateral } \\
\text { Mesa de Jantar para } 6 \text { pessoas+aparador }\end{array}$ \\
\hline Banheiro Social & Lavatório+bacia+chuveiro \\
\hline Lavabo & Bacia+lavatório \\
\hline Banheiro Dormitório casal & Lavatório+bacia+ banheira \\
\hline Copa-Cozinha & 1 fogão +1 geladeira+pia+MLL+mesa ou bancada \\
\hline Dependências de Serviço** & 1 cama + armário \\
\hline Despensa/ rouparia & prateleiras \\
\hline Banheiro de Serviço & Lavatório+bacia+chuveiro \\
\hline Varandas & Mesa+ cadeiras \\
\hline Depósito em subsolo & armários \\
\hline Estacionamento & 2 ou mais vagas \\
\hline
\end{tabular}

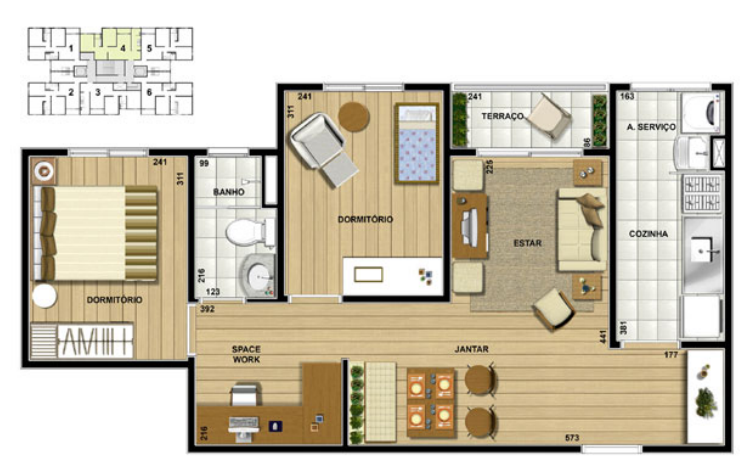

Fig. III 03 Empreendimento 3 - T2 Eco Vitta - finais 3 e 4 Fonte - http://www.ecovittasabara.com.br/ TP Mercado Imobiliário 
Tabela 11-Programa de Mob. e Equip. T4.

Fonte- TP Mercado Imobiliário

\begin{tabular}{|c|c|}
\hline Ambientes & Mobiliário e Equipamento \\
\hline Dormitório Casal Suíte & $\begin{array}{l}1 \text { cama de casal }+2 \text { criados mudos } \\
8 \text { unidades de armário de } 60 \mathrm{~cm} \text { ou closet }+1 \\
\text { cadeira + estante para TV+ bancada ou mesa }\end{array}$ \\
\hline Closet Dormitórios* & 4 ou 6 unidades de armários \\
\hline $\begin{array}{l}\text { Dormitório de Solteiro } \\
\text { Individual }\end{array}$ & $\begin{array}{l}1 \text { cama de solteiro }+1 \text { criado mudo } \\
\text { mesa de estudo }+2 \text { unidades de armário }\end{array}$ \\
\hline Dormitório Solteiro Duplo & $\begin{array}{l}2 \text { camas de solteiro }+1 \text { criado mudo } \\
\text { mesa de estudo }+3 \text { unidades de armário }\end{array}$ \\
\hline $\begin{array}{l}\text { Sala de Estar e Jantar } \\
\text { Conjugadas }\end{array}$ & $\begin{array}{l}\text { Sofás e poltronas ( } 8 \text { assentos)+mesa de centro+ } \\
\text { estante TV+ } 1 \text { mesa lateral } \\
\text { Mesa de Jantar para } 8 \text { pessoas+ aparador+ }\end{array}$ \\
\hline $\begin{array}{l}\text { Banheiro Social e Banheiros } \\
\text { Dormitórios }\end{array}$ & Lavatório+ bacia+ chuveiro \\
\hline Lavabo & Bacia+lavatório \\
\hline Banheiro Dormitório Casal & Lavatório+bacia+chuveiro+ banheira+bidê \\
\hline Copa-Cozinha & $\begin{array}{l}1 \text { fogão } 6 \text { bocas }+1 \text { geladeira+freezer+pia+MLL+ } \\
\text { mesa ou bancada com assentos }\end{array}$ \\
\hline Dependências de Serviço** & 1 cama + armário+ estante TV \\
\hline Banheiro de Serviço & Lavatório+bacia+chuveiro \\
\hline Área de Serviço & $\begin{array}{l}1 \text { tanque }+1 \text { máquina de lavar roupa+ máquina de } \\
\text { secar roupa+ armário+ tábua de passar }+3 \\
\text { unidades de varais de teto }\end{array}$ \\
\hline Despensa/rouparia & prateleiras \\
\hline Varandas & Mesa+ cadeiras+churrasqueira \\
\hline Depósito em subsolo & armários \\
\hline Estacionamento & 3 ou mais vagas \\
\hline
\end{tabular}

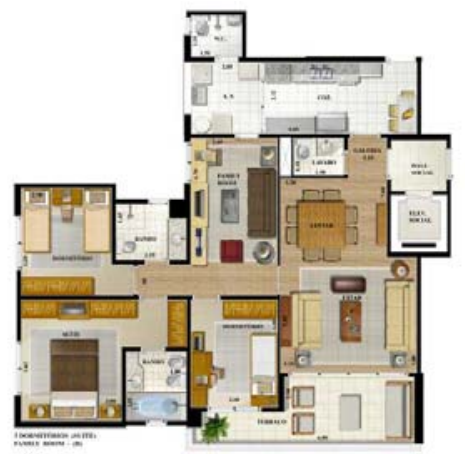

Fig. III 04 Empreendimento 166 - T4 Arandu Fonte - TP Mercado Imobiliário 


\subsubsection{Elementos de Avaliação Mobiliário e Equipamentos}

Os elementos de avaliação também foram adaptados mas seguindo as diretrizes do Método, as necessidades e o modo de vida apresentam algumas diferenças , entre Portugal e Brasil. Exemplo: a importância da previsão de lareiras, aqui são menos necessárias como devido ao clima.

Apesar de termos programas distintos, pudemos unir em um único conjunto os elementos de avaliação, a saber;

\section{Cozinha (preparo de alimentos)}

A A cozinha comporta fogão (6 Bocas para T4)+geladeira + freezer+ M.L.L. 3

B A cozinha comporta Fogão+ Geladeira+ Freezer + Bancada 2

C A cozinha comporta Geladeira+ Fogão+ Bancada de preparo 1

\section{Arrumação da Casa (Índice de Armários de roupas/ pessoa)}

Gráfico 4 Indice de módulos de armários por pessoa Fonte autor Este critério seguiu orientação direta de PEDRO,J.B.

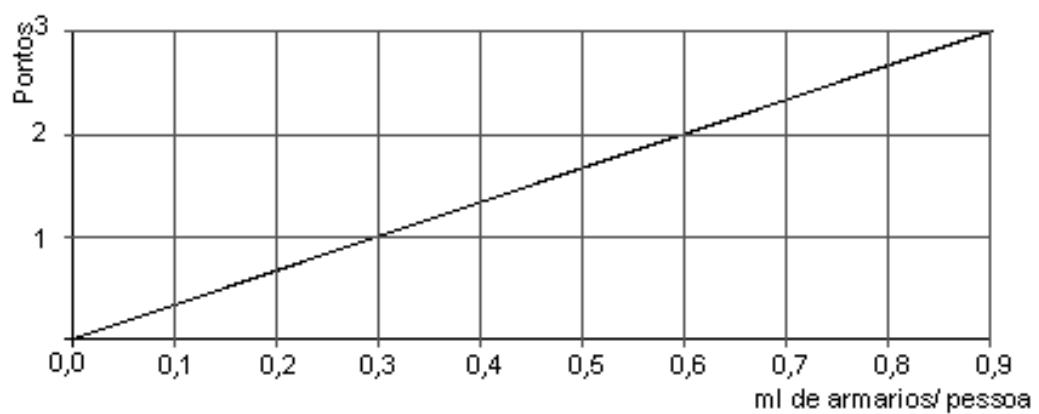

\section{3. Área de Serviço (Cuidados com a Roupa/ Manutenção)}

A A área de serviço comporta 2 máquinas (lavar e secar)

+tanque + tábua de passar roupas.

B A área de serviço comporta 1 máquina+ 1 tanque

+ tábua de passar roupas ou outra máquina

C A área de serviço comporta 1 máquina + tanque 
A O dormitório do casal, além da cama de casal e mesas de cabeceira, comporta cadeira ou poltrona + mesa para tv.

B O dormitório do casal, além da cama de casal e mesas de cabeceira, comporta mesa para tv ou cadeira.

C O dormitório de casal comporta apenas a cama de casal e as mesas de cabeceira. 1

\section{$\underline{\text { 5. Lazer/ Trabalho adulto / Estudo }}$}

A A habitação comporta + de 1 mesa de trabalho 3

B A habitação comporta 1 mesa de estudo 2

C A habitação não comporta local de trabalho 1

\section{Arrumação /Manutenção}

A A habitação possui roupeiro ${ }^{1}$ ou armário na área de serviço 3

B A habitação possui roupeiro ou armário na área de serviço 2

C A habitação não possui roupeiro nem armário na área de serviço 1

Notas:

$$
\begin{aligned}
& \text { 1.O número de varais de teto para } \quad \text { T2 = } 1 \text { varal } \\
& \text { T3 = } 2 \text { varais } \mathrm{e} \\
& \text { T4 = } 3 \text { varais no mínimo. }
\end{aligned}
$$

2.Roupeiro é entendido como armário fora dos dormitórios, destinado a roupas de cama e banho. 


\subsection{Critério adotado para a Avaliação de Mobiliário e Equipamentos}

Gráfico 5 Critérios de Avaliação Mobiliário e Equipamentos - Fonte - MÉTODO.

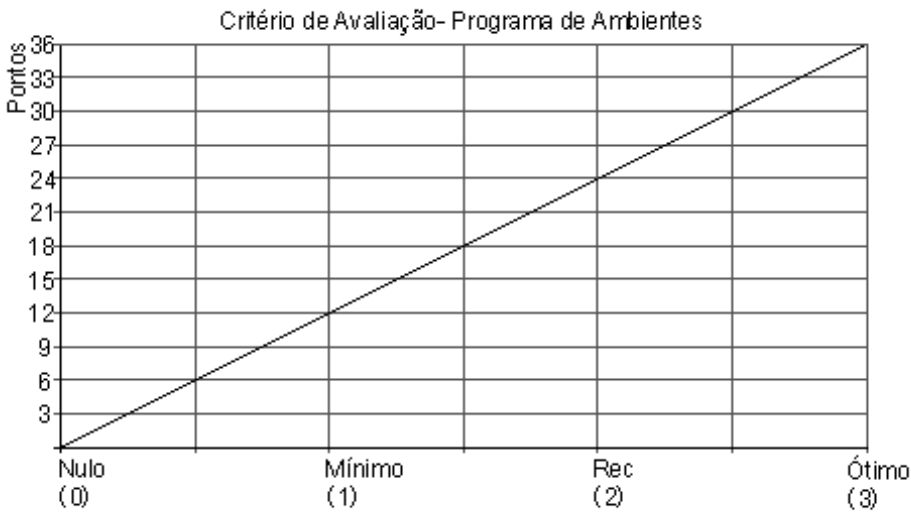

Tabela 12

Valor de Desempenho Mobiliário e Equipamentos Fonte: METODO

\begin{tabular}{|c|c|c|}
\hline Nulo & 0 & 0 \\
\hline Mínimo & 9 & 1 \\
\hline Recomendável & 18 & 2 \\
\hline Ótimo & 27 & 3 \\
\hline
\end{tabular}

\subsection{Resultados da Avaliação de Mobiliário e Equipamentos}

Tabela 13 Resumo da Avaliação Mobiliário e Equipamentos T2 - Fonte autor

\begin{tabular}{|c|c|c|c|c|c|c|c|c|c|c|c|}
\hline \multicolumn{2}{|c|}{ Empreendimentos } & \multicolumn{2}{|c|}{1} & \multicolumn{2}{|c|}{2} & \multicolumn{2}{|c|}{3} & \multicolumn{2}{|c|}{4} & \multicolumn{2}{|c|}{5} \\
\hline & & Pontos & Ptos * & Pontos & Ptos * & Pontos & Ptos * & Pontos & Ptos * & Pontos & Ptos * \\
\hline Perguntas & Pond. & & Pond. & & Pond. & & Pond. & & Pond. & & Pond. \\
\hline 1 & 2 & 1 & 2 & 1 & 2 & 1 & 2 & 1 & 2 & 1 & 2 \\
\hline 2 & 1 & 3 & 3 & 3 & 3 & 3 & 3 & 3 & 3 & 3 & 3 \\
\hline 3 & 2 & 1 & 2 & 1 & 2 & 1 & 2 & 4 & 2 & 1 & 2 \\
\hline 4 & 1 & 2 & 2 & 2 & 2 & 1 & 1 & 1 & 1 & 1 & 1 \\
\hline 5 & 1 & 2 & 2 & 2 & 2 & 1 & 1 & 1 & 1 & 1 & 1 \\
\hline 6 & 1 & 1 & 1 & 1 & 1 & 1 & 1 & 1 & 1 & 1 & 1 \\
\hline \multicolumn{2}{|c|}{ Somatória } & & 12 & & 12 & & 10 & & 11 & & 10 \\
\hline \multicolumn{2}{|c|}{ V. de Desempenho } & \multicolumn{2}{|c|}{1,33} & \multicolumn{2}{|c|}{1,33} & \multicolumn{2}{|c|}{1,11} & \multicolumn{2}{|c|}{1,33} & \multicolumn{2}{|c|}{1,11} \\
\hline
\end{tabular}

Considerando-se os valores da Tabela 13 acima, as plantas da tipologia T2 possuem um desempenho mínimo, segundo o MÉTODO, apesar da variação de área privativa. Foram considerados nesta avaliação, apenas o mobiliário e os equipamentos representados nas plantas de vendas. Estes resultados recomendam uma avaliação da capacidade avaliada no elemento funcionalidade. 
Tabela 14 Resumo da Avaliação Mobiliário e Equipamentos T3

Fonte - autor

\begin{tabular}{|c|c|c|c|c|c|c|c|c|c|c|c|}
\hline \multicolumn{2}{|c|}{ Empreendimentos } & \multicolumn{2}{|c|}{1} & \multicolumn{2}{c|}{2} & \multicolumn{2}{c|}{3} & \multicolumn{2}{c|}{4} & \multicolumn{2}{c|}{5} \\
\cline { 2 - 15 } & Pontos & Ptos * & Pontos & Ptos * & Pontos & Ptos * & Pontos & Ptos * & Pontos & Ptos * \\
\hline Perguntas & Pond. & & Pond. & & Pond. & & Pond. & & Pond. & & Pond. \\
\hline 1 & 2 & 3 & 6 & 1 & 2 & 2 & 4 & 2 & 4 & 1 & 2 \\
\hline 2 & 1 & 3 & 3 & 3 & 3 & 3 & 3 & 3 & 3 & 3 & 3 \\
\hline 3 & 2 & 3 & 6 & 2 & 4 & 2 & 4 & 2 & 4 & 2 & 4 \\
\hline 4 & 1 & 3 & 3 & 1 & 1 & 2 & 2 & 2 & 2 & 2 & 2 \\
\hline 5 & 1 & 2 & 2 & 2 & 2 & 1 & 1 & 2 & 2 & 1 & 1 \\
\hline 6 & 1 & 1 & 1 & 1 & 1 & 2 & 2 & 2 & 2 & 1 & 1 \\
\hline \multicolumn{2}{|c|}{ Somatória } & & 21 & & 13 & & 16 & & 17 & & 13 \\
\hline
\end{tabular}

Tabela 15 Resumo da Avaliação Mobiliário e Equipamentos T4

Fonte autor

\begin{tabular}{|c|c|c|c|c|c|c|c|c|c|c|c|}
\hline \multirow{2}{*}{\multicolumn{2}{|c|}{ Empreendimentos }} & \multirow{2}{*}{\multicolumn{2}{|c|}{7}} & \multirow{2}{*}{\multicolumn{2}{|c|}{12}} & \multirow{2}{*}{\multicolumn{2}{|c|}{18}} & \multirow{2}{*}{\multicolumn{2}{|c|}{19}} & \multirow{2}{*}{\multicolumn{2}{|c|}{49}} \\
\hline & & & & & & & & & & & \\
\hline Perguntas & Pond. & Pontos & $\begin{array}{c}\text { Ptos. } \\
x \\
\text { Pond. } \\
\end{array}$ & Pontos & $\begin{array}{c}\text { Ptos. } \\
x \\
\text { Pond. }\end{array}$ & Pontos & $\begin{array}{c}\text { Ptos. } \\
x \\
\text { Pond. }\end{array}$ & Pontos & $\begin{array}{c}\begin{array}{c}\text { Ptos. } \\
\mathrm{x}\end{array} \\
\text { Pond. }\end{array}$ & Pontos & $\begin{array}{c}\begin{array}{c}\text { Ptos. } \\
\mathrm{x}\end{array} \\
\text { Pond } \\
\end{array}$ \\
\hline 1 & 2 & 2 & 4 & 3 & 6 & 3 & 6 & 2 & 4 & 3 & 6 \\
\hline 2 & 1 & 3 & 3 & 2 & 2 & 3 & 3 & 3 & 3 & 3 & 3 \\
\hline 3 & 1 & 2 & 2 & 3 & 3 & 3 & 3 & 2 & 2 & 3 & 3 \\
\hline 4 & 2 & 3 & 6 & 2 & 4 & 3 & 6 & 2 & 4 & 1 & 2 \\
\hline 5 & 2 & 3 & 6 & 3 & 6 & 2 & 4 & 1 & 2 & 2 & 4 \\
\hline 6 & 1 & 2 & 2 & 3 & 3 & 2 & 2 & 1 & 1 & 2 & 2 \\
\hline \multicolumn{2}{|c|}{ Somatória } & & 23 & & 24 & & 24 & & 16 & & 20 \\
\hline \multicolumn{2}{|c|}{ V. de Desempenho } & \multicolumn{2}{|c|}{2,56} & \multicolumn{2}{|c|}{2,67} & \multicolumn{2}{|c|}{2,67} & \multicolumn{2}{|c|}{1,78} & \multicolumn{2}{|c|}{2,22} \\
\hline
\end{tabular}


Tabela 15 (continuação) Resumo da Avaliação Mobiliário e Equipamentos T4 Fonte autor

\begin{tabular}{|c|c|c|c|c|c|c|c|c|c|c|c|}
\hline \multirow{2}{*}{\multicolumn{2}{|c|}{ Empreendimentos }} & \multirow{2}{*}{\multicolumn{2}{|c|}{113}} & \multirow{2}{*}{\multicolumn{2}{|c|}{165}} & \multirow{2}{*}{\multicolumn{2}{|c|}{166}} & \multirow{2}{*}{\multicolumn{2}{|c|}{167}} & \multirow{2}{*}{\multicolumn{2}{|c|}{168}} \\
\hline & & & & & & & & & & & \\
\hline & & \multirow[t]{2}{*}{ Pontos } & \multirow{2}{*}{$\begin{array}{c}\text { Ptos. } \\
\mathrm{x}\end{array}$} & \multirow[t]{2}{*}{ Pontos } & \multirow{2}{*}{$\begin{array}{c}\text { Ptos. } \\
\mathrm{x}\end{array}$} & \multirow[t]{2}{*}{ Pontos } & \multirow{2}{*}{\begin{tabular}{|c}
$\begin{array}{c}\text { Ptos. } \\
\mathrm{x}\end{array}$ \\
Pond. \\
\end{tabular}} & \multirow[t]{2}{*}{ Pontos } & \multirow{2}{*}{$\begin{array}{c}\begin{array}{c}\text { Ptos. } \\
\mathrm{x}\end{array} \\
\text { Pond. }\end{array}$} & \multirow[t]{2}{*}{ Pontos } & \multirow{2}{*}{\begin{tabular}{|c}
$\begin{array}{c}\text { Ptos. } \\
\mathrm{x}\end{array}$ \\
Pond. \\
\end{tabular}} \\
\hline Perguntas & Pond. & & & & & & & & & & \\
\hline 1 & 2 & 3 & 6 & 3 & 6 & 3 & 6 & 3 & 6 & 3 & 6 \\
\hline 2 & 1 & 3 & 3 & 3 & 3 & 3 & 3 & 3 & 3 & 3 & 3 \\
\hline 3 & 1 & 3 & 3 & 3 & 3 & 3 & 3 & 3 & 3 & 2 & 2 \\
\hline 4 & 2 & 3 & 6 & 3 & 6 & 2 & 4 & 1 & 2 & 2 & 4 \\
\hline 5 & 2 & 3 & 6 & 1 & 2 & 2 & 4 & 3 & 6 & 2 & 4 \\
\hline 6 & 1 & 2 & 2 & 1 & 1 & 2 & 2 & 2 & 2 & 1 & 1 \\
\hline \multicolumn{2}{|l|}{ Somatória } & & 26 & & 21 & & 22 & & 22 & & 20 \\
\hline \multicolumn{2}{|l|}{ Valor de } & \multicolumn{2}{|c|}{2,89} & \multicolumn{2}{|c|}{2,33} & \multicolumn{2}{|c|}{2,44} & \multicolumn{2}{|c|}{2,44} & \multicolumn{2}{|c|}{2,22} \\
\hline
\end{tabular}

Gráfico 6 - Variação dos Valores de Desempenho dos Programas de Mobiliário e equipamentos de todos os Empreendimentos, por área Privativa.

Fonte autor

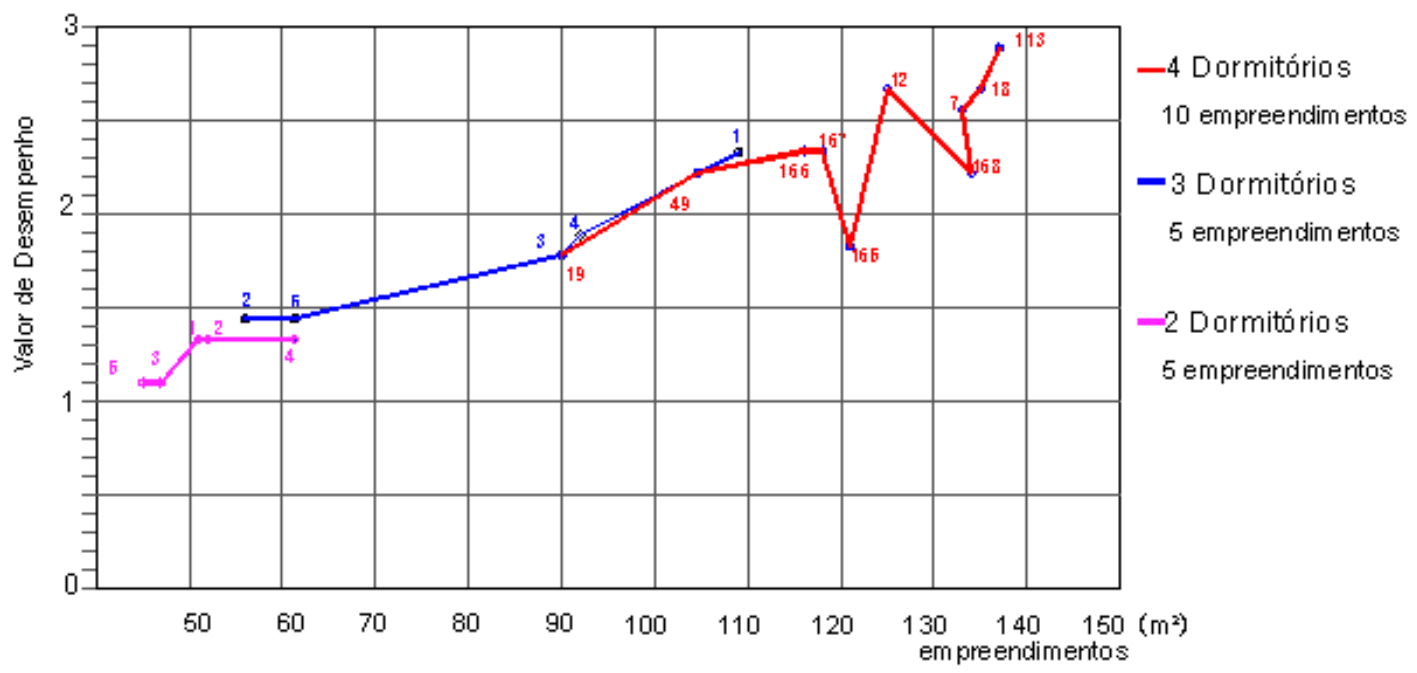


2.1.1.2.4. Análise dos Resultados obtidos para Programa de Mobiliário e Equipamentos.

Pode-se constar que a grande maioria dos apartamentos de 2 dormitórios suporta de forma mínima os equipamentos e o mobiliário pesquisados no inventário. A $\mathrm{CEF}^{11}$ não inclui na sua listagem a máquina de lavar louça e o forno de micro ondas, o que poderia justificar a falta de tais equipamentos principalmente nos apartamentos de 2 dormitórios.

Os apartamentos de 3 e 4 dormitórios, possuem uma capacidade maior de suportar o mobiliário e os equipamentos, de acordo com os valores de desempenho obtidos, que por sua vez estão estreitamente relacionados a área privativa dos empreendimentos, ou seja, quanto maior a área maior o valor de desempenho para este elemento da avaliação.

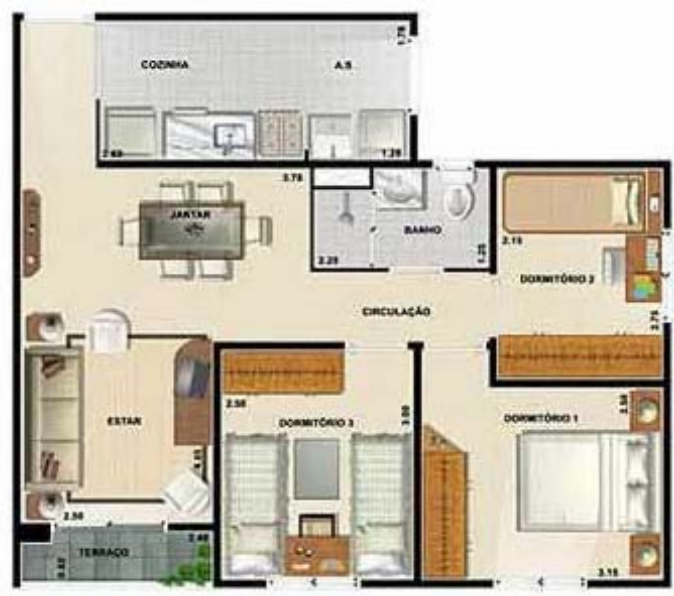

Fig. III 05 Empreend. 5 T3 City Park

Fonte: TP Mercado Imobiliário

Área privativa $=61,20 \mathrm{~m}^{2}$

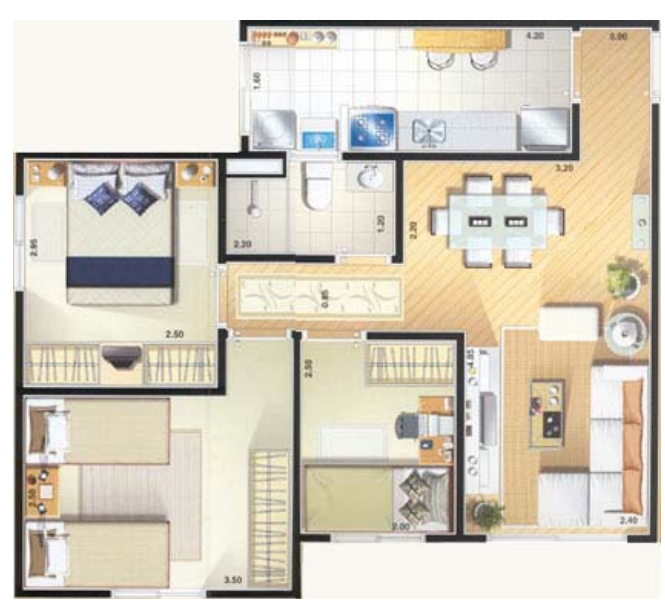

Fig. III 06 Empreend. 2 T3 Spazio Norte Fonte: TP Mercado Imobiliário Área privativa $=56,00 \mathrm{~m}^{2}$

As figuras 5 e 6 são dos 2 empreendimentos com os menores valores de desempenho, quanto a mobiliário e equipamentos, principalmente devido à falta de equipamentos na cozinha e na área de serviço.

${ }^{11}$ Caixa Econômica Federal 
A maior parte dos apartamentos de 3 e 4 dormitórios atende ao programa, porém, muitas vezes o que está representado não comporta o espaço de atividades, necessário, quer dizer, que na realidade não comportam o mobiliário e os equipamentos. Os apartamentos de 4 dormitórios com área inferior, ou igual aos de 3 dormitórios tem o seu valor de desempenho prejudicado, como mostra o gráfico 6 .

Pode-se concluir que:

- O fato dos elementos de avaliação serem os mesmo para todas as tipologias, poder ter acarretado o aumento dos valores de desempenho nos apartamentos de 4 dormitórios, o que pode indicar uma reavaliação nos pontos de vista e nas suas ponderações .

- Estão sendo comercializados apartamentos que não comportam o mobiliário e os equipamentos mínimos necessários.

- Os compradores não avaliam a capacidade de suportar mobiliário e equipamentos, por isto estas peças não estão representadas nas peças promocionais.

- A compartimentação pode influir no valor de desempenho deste elemento de avaliação, vide gráfico 6 , na faixa de área privativa de $90,00 \mathrm{~m}^{2}$ a $110,00 \mathrm{~m}^{2}$ os valores dos empreendimentos T4 19 e 49, não acompanham na mesma proporção os empreendimentos T3 4 e 1 dentro da mesma faixa de área, portanto, a compartimentação pode ser fator de contribuição na capacidade de colocação de mobiliário e equipamentos. 


\subsubsection{Espaciosidade}

\section{Objetivo:}

As habitações devem conter espaços com áreas capazes de comportar os equipamentos, mobiliário, e espaços de atividades, adequadas à utilização pelo número de usuários e ou tipologia. Como já foi visto no capitulo III iremos avaliar a espaciosidade, através da Dimensão Útil e da Área Útil.

\section{Espaciosidade Dimensão Útil \\ Área Útil}

\subsubsection{Dimensão Útil}

\subsection{Elementos de Avaliação para Dimensão Útil}

Foram utilizados 5 elementos de avaliação, como o METODO prevê. A Dimensão Útil do Vestíbulo, foi substituída pela Dimensão Útil da Varanda, para este elemento de avaliação foram desenvolvidos descritores e critérios de ponderação com base nos ambientes levantados no Inventário BOUERI FAPESP, os demais descritores e elementos de avaliação são os previstos no METODO.

Descritores da Varanda ${ }^{12}$

0 pontos (nulo) $=\varnothing 0,60 \mathrm{~m}$ (de 0,60m até $0,90 \mathrm{~m}$, de 0,40 a 0,60 ainda foi considerado como elementos de fachada).

1 ponto $($ mínimo $)=\varnothing 0,90 \mathrm{~m}$, ambiente comporta espaço para exercer uma única atividade de lazer (apreciação vista).

2 pontos (recomendável) $=\varnothing 2,00 \mathrm{~m}$, ambiente comporta espaço para 2 pessoas exercerem uma atividade de lazer (apreciação vista).

3 pontos (ótimo) $=(3,00 \mathrm{~m}$, ambiente comporta espaço para mais de 2 pessoas exercerem mais de uma atividade .Ex. lazer (apreciação vista) e refeições Churrasqueira.

${ }^{12}$ Vide item 2.2.4 Descritores, Capítulo II 


\subsection{Critério de Avaliação da Dimensão Útil}

Gráfico 7 -Critério de Avaliação da Dimensão Útil das Varandas

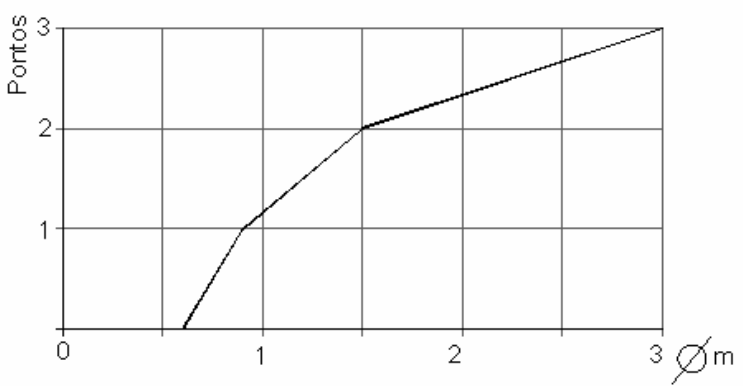

Exemplo de aplicação dos Elementos de Avaliação para a Dimensão Útil em apartamento de 2 Dormitórios.

O $1^{\circ}$ Passo é Identificar a Planta fig. $07,2^{\circ}$ passo inscrever os maiores círculos possíveis nos ambientes, vide fig. 08

Empreendimento 1 -T2 : Home Flex Itaim área privativa 51,00m²

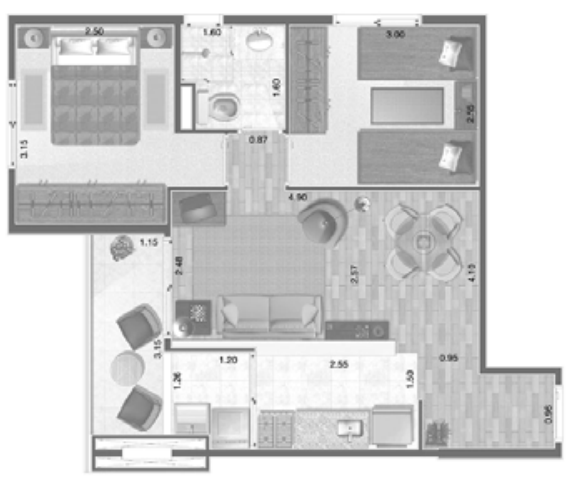

Fig. III 07 Empreend. 1- T2 Home Flex Itaim

Fonte: TP Mercado Imobiliário

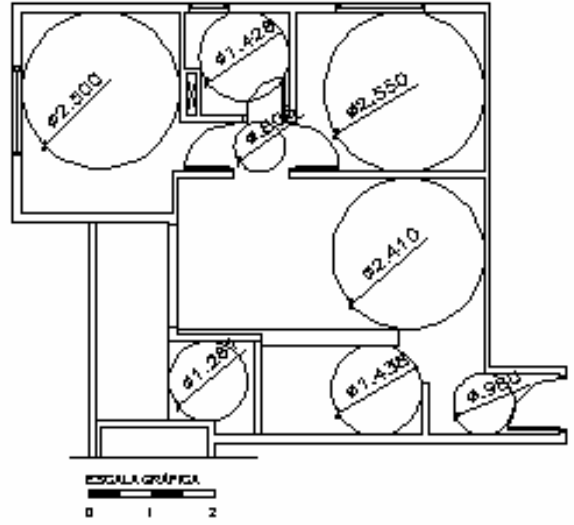

Fig. III 08 Empreend. 1- T2

Desenho com os raios inscritos

Fonte autor 
O $3^{\circ}$ Passo é tabelar as informações encontradas., e o $4^{\circ}$ passo é calcular 0 valor de desempenho com base nos critérios da tabela 17.

\subsection{Resultados da Avaliação da Dimensão Útil}

Os resultados da avaliação da dimensão útil foram resumidos em tabelas como a tabela 16, por empreendimento, gerando assuim o valor de desempenho de cada planta com o critério estabelecido na tabela 17.

Tabela 16- Dimensão Útil T2 Fonte: autor

\begin{tabular}{|l|c|c|c|c|}
\hline \multicolumn{2}{|c|}{ Exigências de Uso } & $\begin{array}{c}\text { Home Flex } \\
\text { Itaim }\end{array}$ & 4 pessoas & T2-1 \\
\hline & \multicolumn{3}{|c|}{ Espaciosidade - Dimensão Útil } \\
\hline AMBIENTES & Diâmetro & Pontuação & Ponderação & Pt*Pond. \\
\hline A de Serviço & 1.26 & - & & \\
\hline Cozinha & 1.44 & 0 & 3 & 0,00 \\
\hline A. Circulação & .80 & 0 & 1 & 0,00 \\
\hline Sala de Estar/Jantar & 2.48 & 0,35 & 3 & 1,05 \\
\hline Dormit.Casal 1 & 2.50 & 1,35 & & 0,00 \\
\hline Dormit. Solt. 2d & 2.55 & 2,2 & & 0,00 \\
\hline Média Dormitórios & & 3,55 & 3 & 10,65 \\
\hline Banheiro Social & 1.43 & - & & \\
\hline Varanda & 1.15 & 1,30 & 1 & 1,30 \\
\hline TOTAL & & & & 13,00 \\
\hline Área Privativa $=51,17 m^{2}$ & & & & \\
\hline
\end{tabular}

$4^{\circ}$ Passo- Calcular o Valor de Desempenho

Tabela 17- Valor de Desempenho Dimensão Útil Fonte METODO

\begin{tabular}{|l|c|c|}
\hline & Pontos & V. de Desempenho \\
\hline Ótimo & 24 & 3 \\
\hline Recomendável & 16 & 2 \\
\hline Mínimo & 8 & 1 \\
\hline
\end{tabular}

O empreendimento T2 - 1 obteve o valor de desempenho 1,65 no elemento Dimensão Útil, utilizando o Critério de Avaliação do MÉTODO,segundo a tabela 17. 
Gráfico 8 Variação do Valor de Desempenho da Dimensão Útil em função da Área Privativa

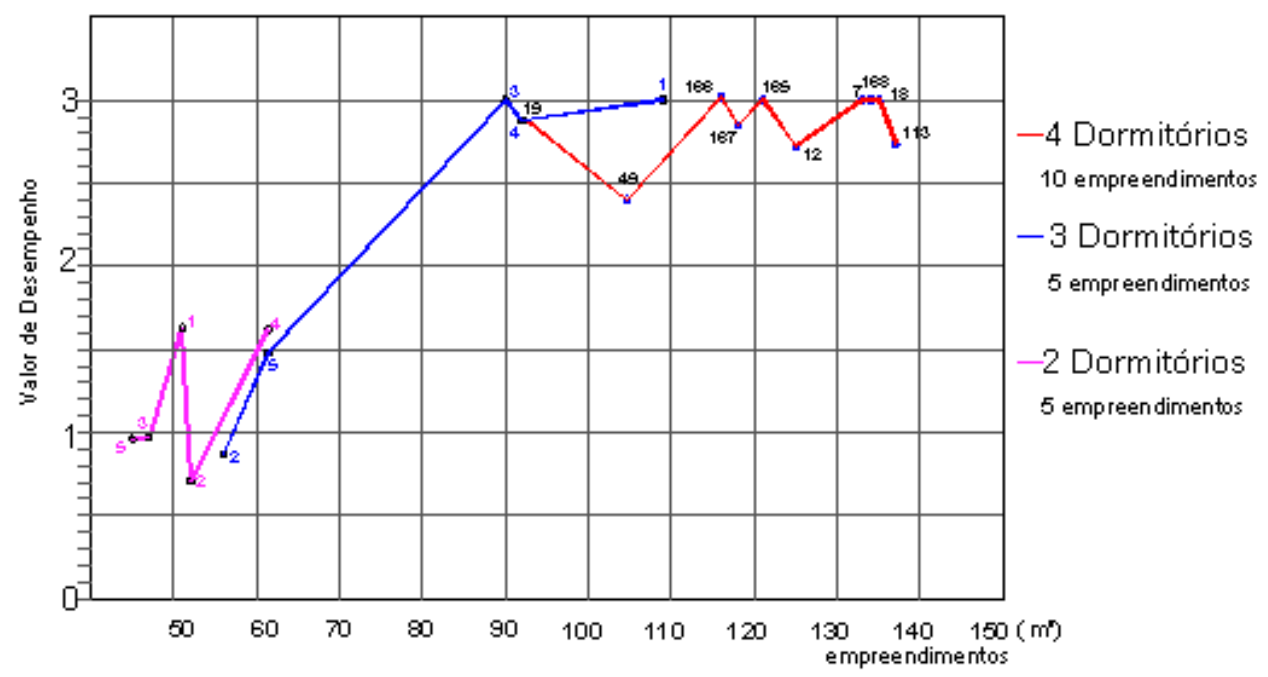

\subsubsection{2. Área Útil}

\subsubsection{2 . Elementos de Avaliação para Área Útil}

Foram utilizados elementos de avaliação por tipologia, seguindo o MÉTODO, com um total de 5. O elemento no 5- Área Útil dos Espaços de Comunicação e arrumação, foi substituído pela área Útil das Varandas, por motivos de hábitos e clima. Para este elemento de avaliação foram desenvolvidos descritores e critérios de ponderação com base nos ambientes levantados no Inventário BOUERI FAPESP, a saber:

\subsection{Critério de Avaliação da Área Útil}

Os critérios adotados seguiram os do MĖTODO, a seguir estão os critérios adotados para a avaliação das varandas:

\section{Descritores:}

0 ponto $=0,60 \mathrm{~m}^{2}$

1 ponto $=0,90 \times 2,00 \mathrm{~m}=1,80 \mathrm{~m}^{2}$, ambiente comporta espaço para exercer uma única atividade de lazer (apreciação vista).

2 pontos $=1,60 \times 3,00=4,80 \mathrm{~m}^{2}$, ambiente comporta espaço para 2 pessoas exercerem uma atividade (apreciação da vista ou refeições). 
3 pontos $=4,00 \times 2,00=8,00 \mathrm{~m}^{2}$, ambiente comporta espaço para mais de 2 pessoas exercerem mais de uma atividade. Ex. lazer (apreciação da vista) e refeições ou ainda a instalação de uma Churrasqueira.

Gráfico 9 Critério de Avaliação da Área Útil da Varanda Fonte autor

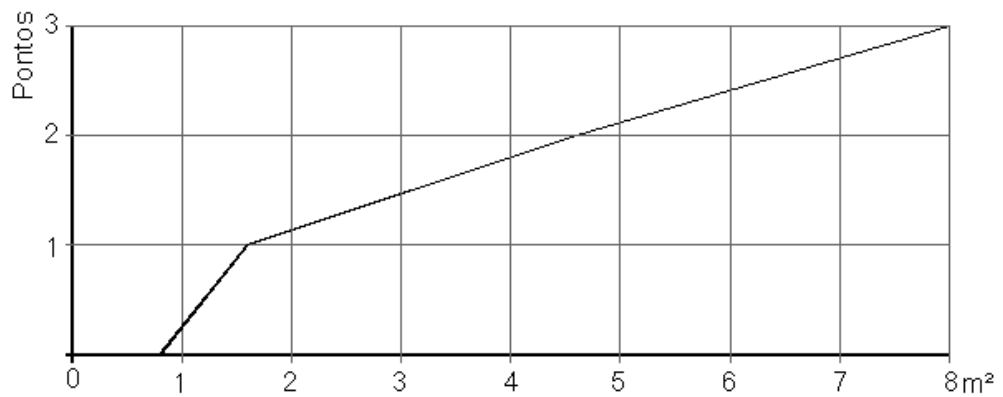

\subsection{Resultados Obtidos Área Útil}

Os resultados foram obtidos da seguinte forma; os dados foram tabelados, como mostra a tabela 18 para todos os empreendimentos estudados. As tabelas tiveram como base, desenhos como o da figura 09, para cada empreendimento (os desenhos foram realizados em escala sobre imagem digitalizada, em arquivos de extensão DWG).

A área dos ambientes foi somada de acordo com as atividades afins desenvolvidas nos ambientes, conforme indica o METODO, a saber:

1. Serviços- manutenção da casa e preparo de refeições

2. Salas- estar/ receber

3. Dormitórios - descanso/ dormir

4. Banheiros - higiene pessoal

5. Varanda - lazer 


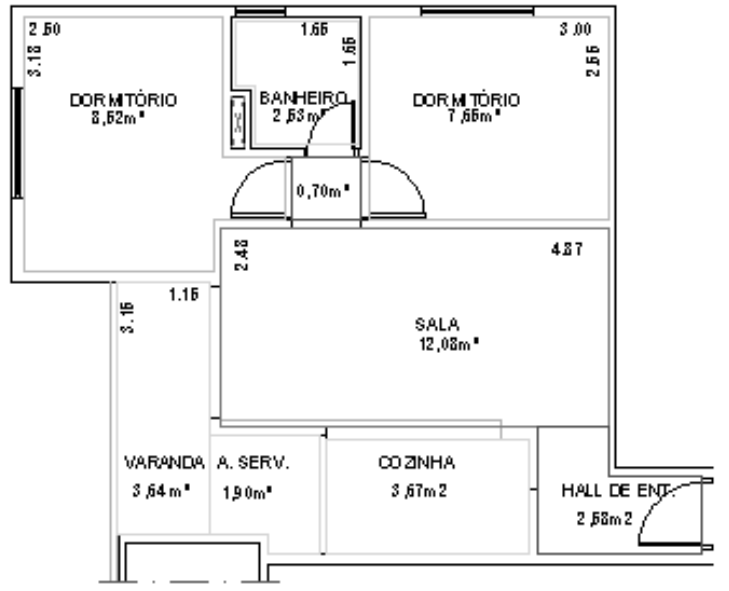

ESCALA GRARCA 1) 12
Fig. III 09 Empreend. 1-T2 Desenho - ÀREA ÚTIL

Fonte autor
O empreendimento 1 , figura III 09 obteve o valor de desempenho 0,2 no elemento Área Útil, utilizando o Critério de Avaliação do MÉTODO, segundo a tabela 22 abaixo, mesmo sendo o apartamento de 2 dormitórios com maior área privativa.

Tabela 21- Área Útil Empreendimento 1 T2 : Home Flex Itaim

\begin{tabular}{|c|c|c|c|c|}
\hline Exigências de Uso & \multicolumn{4}{|c|}{ 4 pessoas 2D-1 } \\
\hline & \multicolumn{2}{|c|}{ Espaciosidade - Área Útil } \\
\hline AMBIENTES & $\begin{array}{c}\text { Área } \\
\text { Útil }\end{array}$ & Pontuação & Ponderação & Media \\
\hline A de Serviço & 1,90 & & & \\
\hline Cozinha & 3,67 & & & \\
\hline Total Serviços & 5,57 & 0,00 & 3,00 & 0,00 \\
\hline A. Circulação & 3,39 & 0,00 & 2,00 & 0,00 \\
\hline Sala de Estar/Jantar & 12,08 & 0,00 & & 0,00 \\
\hline Sala Intima & 0,00 & & & \\
\hline Total- Salas & 12,08 & 0,00 & 3,00 & 0,00 \\
\hline Dormitório Casal 1 & 8,52 & & & \\
\hline Dormitório Solteiro 2 d & 7,65 & & & \\
\hline Total Dormitórios & 16,17 & 0,00 & 3,00 & 0,00 \\
\hline Banheiro Social & 2,53 & & & \\
\hline Total- Banheiros & 2,53 & 0,00 & 1,00 & 0,00 \\
\hline Varanda & 3,64 & 2,00 & 1,00 & 2,00 \\
\hline Total & & & & 2,00 \\
\hline Área Privativa 51,17m ${ }^{2}$ & & & & \\
\hline
\end{tabular}


Tabela 19- Valor de Desempenho Área Útil Fonte:MÉTODO

\begin{tabular}{|l|c|c|}
\hline & Pontos & V. de Desempenho \\
\hline Ótimo & 36 & 3 \\
\hline Recomendável & 24 & 2 \\
\hline Mínimo & 12 & 1 \\
\hline
\end{tabular}

Após a execução das tabelas de área útil os valores de desempenho foram avaliados conforme critério da tabela 19.

\subsubsection{Resultados Obtidos para a Espaciosidade}

Os resultados obtidos para os valores de desempenho da dimensão útil e da área útil, foram resumidos nas tabelas 20 e 21 abaixo.

Tabela 20 Resumo da Avaliação da Espaciosidade T2 e T3

\begin{tabular}{|l|c|c|c|c|c|c|c|c|c|c|}
\hline Tipologia & \multicolumn{5}{|c|}{ T3-3 Dormitórios } & \multicolumn{5}{|c|}{ T2- 2 Dormitórios } \\
\hline Empreendimentos & 1 & 2 & 3 & 4 & 5 & 1 & 2 & 3 & 4 & 5 \\
\hline Dimensão Útil & 3,00 & 0,87 & 3,00 & 2,88 & 1,48 & 1,63 & 0,71 & 0,97 & 1,62 & 0,96 \\
\hline Área Útil & 2,00 & 0,00 & 0,90 & 0,75 & 0,00 & 0,20 & 0,30 & 0,00 & 0,55 & 0,00 \\
\hline
\end{tabular}

Tabela 21 Resumo da avaliação da Espaciosidade para Apartamentos T4

\begin{tabular}{|l|c|c|c|c|c|c|c|c|c|c|}
\hline Tipologia & \multicolumn{10}{|c|}{ T4 Dormitórios } \\
\hline Empreendimentos & 7 & 12 & 18 & 19 & 49 & 113 & 165 & 166 & 167 & 168 \\
\hline Dimensão Útil & 3,57 & 2,72 & 3,17 & 2,30 & 2,40 & 2,74 & 3,36 & 3,41 & 2,85 & 3,41 \\
\hline Área Útil & 1,85 & 1,83 & 2,26 & 0,51 & 1,42 & 1,84 & 1,74 & 1,83 & 1,84 & 2,28 \\
\hline
\end{tabular}


Gráfico10 Variação do Valor de Desempenho da Área Útil em função da Área Privativa

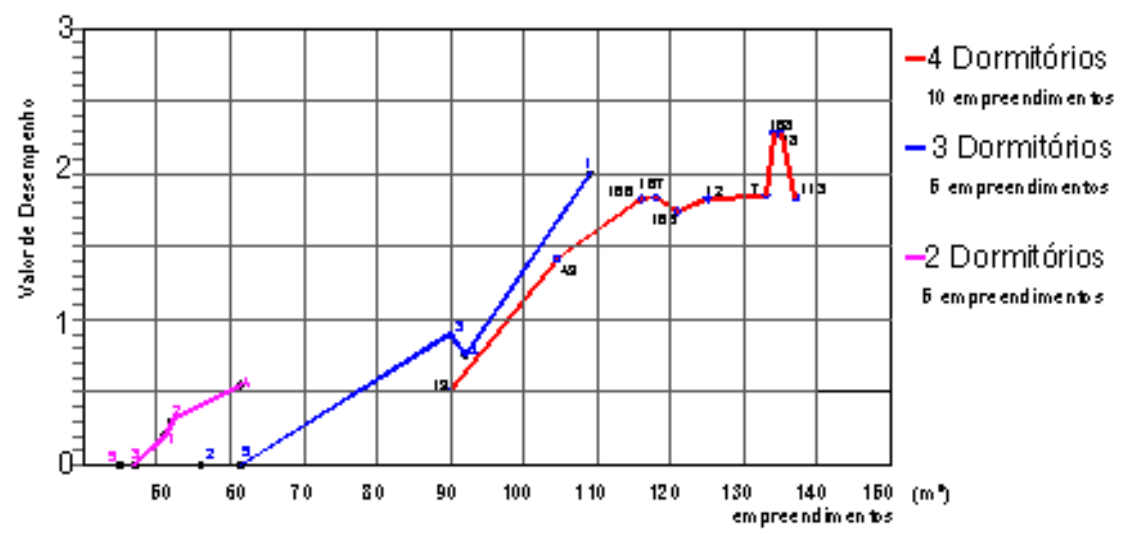

2.1.2..4.Análise dos Resultados de Obtidos para Espaciosidade Área Útil

O gráfico 8 apresenta a discrepâncias entre os empreendimentos 18 e 168 comparados aos apartamentos 7 e 113, por estarem todos dentro da mesma faixa de área privativa entre 130,00 e $140,00 \mathrm{~m}^{2}$ e terem os valores de desempenho dos dois primeiros acima do recomendável e dos dois últimos abaixo, devido principalmente a;

- A área destinada a serviços nos apartamentos 168 e 113, gerou uma pontuação respectivamente de 9,00 e 6,60, enquanto no apartamento 7 foi de 3 (após a ponderação).

- A área destinada a dormitórios no apartamento 18 gerou 7,35 pontos contra 5,25 pontos do apartamento 113 .

A somatória de área destinada aos banheiros foi equivalente em quase todos os apartamentos gerando uma pontuação 3 , com exceção do apartamento 19, que possui apenas 3 banheiros pequenos, e obteve a pontuação 1.

A área útil dos compartimentos dos apartamentos de 2 dormitórios fica abaixo do recomendável, segundo o MÉTODO, estando apenas acima dos empreendimentos 2 e 5 de 3 dormitórios.

Os apartamentos de 3 dormitórios foram os que apresentaram a maior variação no valor de desempenho e apesar da variação acompanhar a área 
privativa de cada um deles, é necessário reavaliar os critérios adotados e respectivas ponderações. Pode-se também verificar que os apartamentos de número 5 e 2 possuem um pseudo $3^{\circ}$ dormitório, é um dos dormitórios com área de aproximadamente $5,00 \mathrm{~m}^{2}$, valor mínimo exigido pela PMSP (segundo o Código de $\mathrm{Obras}^{12}$ ), porém, inferior aos patamares mínimos adotados pelo método e pelos Índices Ergonômicos objeto de pesquisa do Prof. Dr. Boueri, que considera as áreas de dormitórios entre 6 e $8 \mathrm{~m}^{2}$ como precárias para dormitórios simples (para 1 pessoa), vide página 23 o Capítulo II.

\section{Dimensão Útil}

A variação dos valores de desempenho das dimensões úteis, que avalia a dimensão do maior círculo inscrito dentro de cada ambiente, representada no gráfico 9, apresenta os seguintes valores, segundo o MÉTODO:

- valores ótimos, para os apartamentos de 4 dormitórios

- valores recomendáveis para os de 3 dormitórios.

- valores mínimos para os de 2 dormitórios.

\subsubsection{Funcionalidade}

Para a avaliação da funcionalidade, o método utiliza blocos de desenho com os móveis e equipamentos contornados por uma envoltória. Para a avaliação da funcionalidade forma utilizados os "espaços de atividades"13 desenvolvidos pelo Prof. Dr. BOUERI,J.J. 2004 , pois associam as atividades ao mobiliário e equipamentos aos espaços que necessitam ${ }^{14}$, utilizando-se dos índices ergonômicos.Alguns dos elementos de avaliação foram adaptados.

\subsubsection{Elementos de Avaliação da Funcionalidade}

Foram adotados 13 elementos de avaliação para a funcionalidade, seguindo o MÉTODO, porém alguns itens foram adaptados, como o caso da

\footnotetext{
${ }^{12}$ Lei 11.228/92 e DECRETO No 32.329, de 23 de setembro de 1992.

${ }^{13}$ Verificar Anexo 1.

${ }^{14}$ Vide todos os desenhos utilizados no anexo 11.
} 
área destinada ao tratamento de roupa (área de serviço), foi substituído pelas atividades desenvolvidas nas varandas.

Para a realidade portuguesa a existência da área de serviço, já é um fator preponderante, enquanto aqui os apartamentos, por menores que sejam (T2), possuem tal espaço. O questionário foi realizado para obter respostas de falso ou verdadeiro.

Objetivo: As habitações devem proporcionar aos usuários adequadas condições no desenvolvimento das funções de uso da habitação.

\section{Elementos de Avaliação}

Respostas em Falso e Verdadeiro

1. Em todos os dormitórios é possível colocar as camas e seus respectivos espaços de atividade e existe distancia mínima entre o pé da cama e a parede oposta / obstáculo de pelo menos $0,50 \mathrm{~m}$ ?

2. Existe espaço para abrir os gaveteiros sem obstrução em todos os dormitórios na razão de 1 módulo/ pessoa.

3. Existe plano de trabalho de no mínimo $0,40 \mathrm{~m}$ de ambos os lados da cuba na pia da cozinha.

4. Existe plano de trabalho - mesa/ balcão - para desenvolver atividades de preparo de alimentos na posição sentada.

5. O espaço de atividade para o uso da geladeira e do fogão não é obstruído por obstáculos fixos (paredes) ou outro mobiliário..

6. Existem planos de trabalho de no mínimo $0,20 m$ de cada lado do fogão.

7. O percurso de abertura da porta da geladeira ou freezer, não interfere com o espaço de atividade de outros equipamentos, ou com a abertura de portas de acesso.

8. Existe espaço para refeições informais, que não se sobreponha a outros espaços de atividade. 
9. A circulação dentro da cozinha não interfere nos espaços de atividade dos demais equipamentos

10. A área de serviço comporta os equipamentos constantes nos programas de cada tipologia , sem obstáculos e interferências nos devidos espaços de atividade.

11. A área destinada a secagem de roupas é compatível com o número de pessoas na habitação, ou seja T2 - 1 varal T3 2 varais T4 3 varais.

12. Existe um espaço de 0,50m em frente da bacia sanitária e a mesma está distante $0,15 \mathrm{~m}$ de cada lado de qualquer obstáculo, em todos os banheiros.

13. A varanda comporta a atividade ou atividades, especificadas nos programas.

\subsubsection{Critério de Avaliação para Funcionalidade}

A quando a resposta for verdadeira marca-se 1 ponto e multiplica-se pela a ponderação. Os critérios adotados de ponderação e valor de desempenho constam nas tabelas 22 e 23.

Tabela 22 - Ponderação Funcionalidade Fonte autor

\begin{tabular}{|c|c|c|c|c|c|c|c|c|c|c|c|c|c|}
\hline $\begin{array}{c}\text { E. de } \\
\text { Avaliação }\end{array}$ & 1 & 2 & 3 & 4 & 5 & 6 & 7 & 8 & 9 & 10 & 11 & 12 & 13 \\
\hline Ponderação & 2 & 1 & 1 & 1 & 1 & 1 & 2 & 3 & 2 & 1 & 1 & 2 & 2 \\
\hline
\end{tabular}

Tabela 23 -Valores de Desempenho Funcionalidade Fonte autor

\begin{tabular}{|l|c|c|}
\hline & Pontos & Valor de Desempenho \\
\hline Ótimo & 20 & 3 \\
\hline Recomendável & 17 & 2 \\
\hline Mínimo & 10 & 1 \\
\hline Nulo & 0 & 0 \\
\hline
\end{tabular}


Exemplo de desenho para a avaliação da funcionalidade.O Valor de desempenho obtido por este apartamento foi de 0,80 na escala de 1 a 3 como mostra tabela 24 .
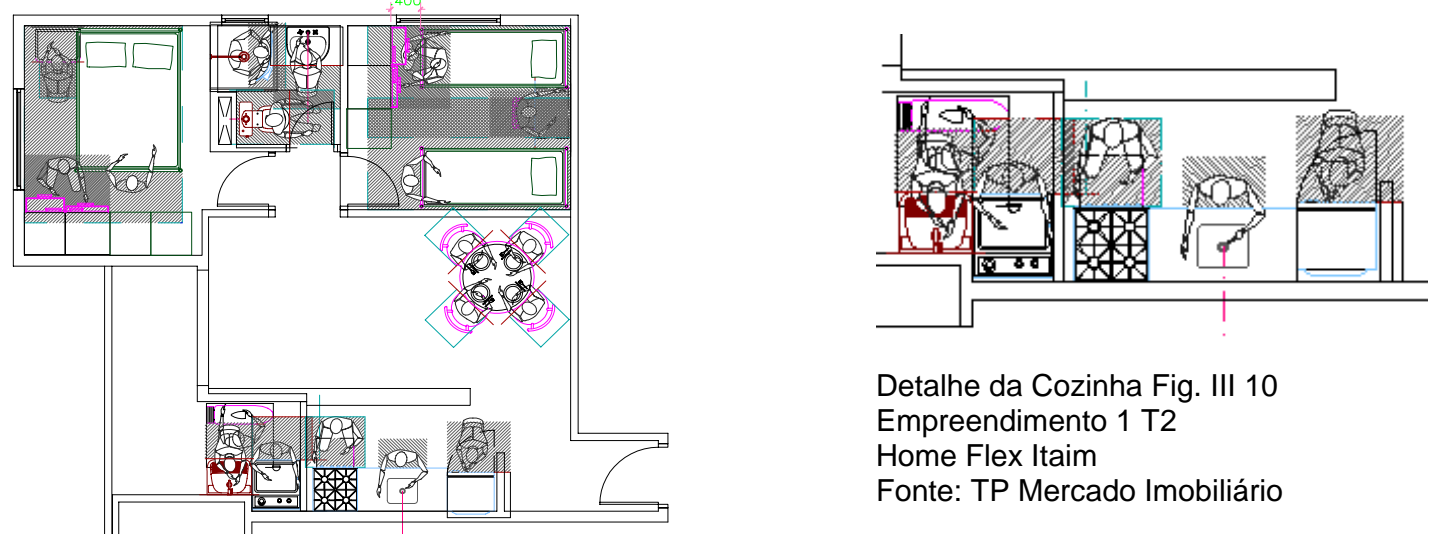

Detalhe da Cozinha Fig. III 10

Empreendimento 1 T2

Home Flex Itaim

Fonte: TP Mercado Imobiliário

Fig. III 10 Desenho Funcionalidade Empreendimento 1- T2 Home Flex Itaim Fonte: TP Mercado Imobiliário

$\mathrm{Na}$ figura 10 pode-se ver o espaço para a abertura da porta da geladeira interferindo com a parede.

\subsubsection{Resultados Obtidos na avaliação da Funcionalidade}

Tabela 24 Funcionalidade para Apartamentos T2 Fonte autor

\begin{tabular}{|c|c|c|c|c|c|c|c|c|c|c|c|}
\hline \multicolumn{2}{|c|}{ Empreendimentos } & \multicolumn{2}{|c|}{1} & \multicolumn{2}{|c|}{2} & \multicolumn{2}{|c|}{3} & \multicolumn{2}{|c|}{4} & \multicolumn{2}{|c|}{5} \\
\hline & & $\mathrm{Fou}$ & $\begin{array}{c}\text { Ptos } \\
\mathrm{X} \\
\end{array}$ & Pontos & \begin{tabular}{|c} 
Ptos \\
$\mathrm{X}$ \\
\end{tabular} & Pontos & $\begin{array}{c}\text { Ptos } \\
\mathrm{x} \\
\end{array}$ & Pontos & $\begin{array}{c}\text { Ptos } \\
\mathrm{X} \\
\end{array}$ & Pontos & $\begin{array}{c}\text { Ptos } \\
\mathrm{X} \\
\end{array}$ \\
\hline Perguntas & Pond. & V & Pond. & & Pond. & & Pond & & Pond. & & Pond. \\
\hline 1 & 2 & $\mathrm{~F}$ & 0 & $\mathrm{~V}$ & 2 & $\mathrm{~F}$ & 0 & $\mathrm{~F}$ & 0 & $\mathrm{~F}$ & 0 \\
\hline 2 & 1 & $\mathrm{~F}$ & 0 & v & 1 & V & 1 & V & 1 & $\mathrm{~F}$ & 0 \\
\hline 3 & 1 & V & 1 & V & 1 & $\mathrm{~F}$ & 0 & V & 1 & V & 1 \\
\hline 4 & 1 & $\mathrm{~F}$ & 0 & V & 1 & $\mathrm{~F}$ & 0 & $\mathrm{~F}$ & 0 & $\mathrm{~F}$ & 0 \\
\hline 5 & 2 & $\mathrm{~F}$ & 0 & $\mathrm{~F}$ & 0 & $\mathrm{~F}$ & 0 & $\mathrm{~F}$ & 0 & $\mathrm{~F}$ & 0 \\
\hline 6 & 1 & $\mathrm{~F}$ & 0 & $\mathrm{~V}$ & 1 & $\mathrm{~F}$ & 0 & $\mathrm{~F}$ & 0 & $\mathrm{~F}$ & 0 \\
\hline 7 & 7 & V & 2 & $\mathrm{~F}$ & 0 & $\mathrm{~F}$ & 0 & $\mathrm{~F}$ & 0 & $\mathrm{~F}$ & 0 \\
\hline 8 & 2 & $\mathrm{~F}$ & 0 & $\mathrm{~F}$ & 0 & $\mathrm{~F}$ & 0 & $\mathrm{~F}$ & 0 & $\mathrm{~F}$ & 0 \\
\hline 9 & 2 & $\mathrm{~F}$ & 0 & $\mathrm{~F}$ & 0 & $\mathrm{~F}$ & 0 & V & 0 & $\mathrm{~F}$ & 0 \\
\hline 10 & 1 & $\mathrm{~V}$ & 1 & $\mathrm{~F}$ & 0 & $\mathrm{~F}$ & 0 & $\mathrm{~V}$ & 0 & $\mathrm{~V}$ & 1 \\
\hline 11 & 1 & $\mathrm{~F}$ & 0 & $\mathrm{~F}$ & 0 & $\mathrm{~F}$ & 0 & $\mathrm{~F}$ & 0 & $\mathrm{~F}$ & 0 \\
\hline 12 & 2 & $\mathrm{~V}$ & 2 & $\mathrm{~V}$ & 2 & $\mathrm{~V}$ & 2 & $\mathrm{~V}$ & 2 & $\mathrm{~F}$ & 0 \\
\hline 13 & 2 & V & 2 & $\mathrm{~F}$ & 0 & $\mathrm{~F}$ & $\mathrm{O}$ & V & 2 & $\mathrm{~F}$ & 0 \\
\hline Somatória & & & 8 & & 8 & & 3 & & 6 & & 2 \\
\hline V. de De & npenho & & & & & 0. & & & & & \\
\hline
\end{tabular}


Tabela 25- Resumo da Avaliação da Funcionalidade para Apartamentos T3

\begin{tabular}{|c|c|c|c|c|c|c|c|c|c|c|c|}
\hline \multirow{2}{*}{\multicolumn{2}{|c|}{ Empreendimentos }} & \multicolumn{2}{|c|}{1} & \multicolumn{2}{|r|}{2} & \multicolumn{2}{|r|}{3} & \multicolumn{2}{|r|}{4} & \multicolumn{2}{|r|}{5} \\
\hline & & \multirow[t]{2}{*}{$\mathrm{F} / \mathrm{V}$} & \multirow{2}{*}{$\begin{array}{l}\text { Ptos } x \\
\text { Pond. }\end{array}$} & \multirow[t]{2}{*}{$\mathrm{F} / \mathrm{V}$} & \multirow{2}{*}{$\begin{array}{l}\text { Ptos } \mathrm{x} \\
\text { Pond. }\end{array}$} & \multirow[t]{2}{*}{$\mathrm{F} / \mathrm{V}$} & \multirow{2}{*}{$\begin{array}{l}\text { Ptos } \mathrm{X} \\
\text { Pond. }\end{array}$} & \multirow[t]{2}{*}{$\mathrm{F} / \mathrm{V}$} & \multirow{2}{*}{$\begin{array}{l}\text { Ptos } \mathrm{x} \\
\text { Pond. }\end{array}$} & \multirow[t]{2}{*}{$\mathrm{F} / \mathrm{V}$} & \multirow[b]{2}{*}{ Pond } \\
\hline Perguntas & Pond. & & & & & & & & & & \\
\hline 1 & 2 & V & 2 & $\mathrm{~F}$ & 0 & V & 2 & V & 2 & $\mathrm{~F}$ & 0 \\
\hline 2 & 1 & $\mathrm{~F}$ & 0 & $\mathrm{~F}$ & 0 & V & 1 & V & 1 & $\mathrm{~F}$ & 0 \\
\hline 3 & 1 & $\mathrm{~V}$ & 1 & V & 1 & V & 1 & V & 1 & $\mathrm{~F}$ & 0 \\
\hline 4 & 1 & V & 1 & $\mathrm{~F}$ & 0 & V & 1 & V & 1 & $\mathrm{~F}$ & 0 \\
\hline 5 & 2 & $\mathrm{~F}$ & 0 & V & 2 & $\mathrm{~F}$ & 0 & V & 2 & V & 2 \\
\hline 6 & 1 & V & 1 & V & 1 & V & 1 & V & 1 & V & 1 \\
\hline 7 & 2 & $\mathrm{~F}$ & 0 & $\mathrm{~F}$ & $\mathrm{O}$ & $\mathrm{F}$ & 0 & $\mathrm{~V}$ & 2 & $\mathrm{~F}$ & 0 \\
\hline 8 & 2 & $\mathrm{~F}$ & 0 & $\mathrm{~F}$ & 0 & V & 2 & $\mathrm{~F}$ & 0 & $\mathrm{~F}$ & 0 \\
\hline 9 & 2 & $\mathrm{~F}$ & 0 & $\mathrm{~F}$ & 0 & $\mathrm{~F}$ & 0 & $\mathrm{~F}$ & 0 & $\mathrm{~F}$ & 0 \\
\hline 10 & 1 & $\mathrm{~V}$ & 1 & $\mathrm{~V}$ & 1 & $\mathrm{~V}$ & 1 & $\mathrm{~V}$ & 1 & $\mathrm{~V}$ & 1 \\
\hline 11 & 1 & $\mathrm{~F}$ & 0 & $\mathrm{~F}$ & 0 & $\mathrm{~V}$ & 1 & $\mathrm{~V}$ & 1 & $\mathrm{~F}$ & 0 \\
\hline 12 & 2 & $\mathrm{~V}$ & 2 & $\mathrm{~V}$ & 2 & $\mathrm{~V}$ & 2 & $\mathrm{~F}$ & 0 & $\mathrm{~V}$ & 2 \\
\hline 13 & 2 & $\mathrm{v}$ & 2 & $\mathrm{~F}$ & 0 & $\mathrm{~V}$ & 2 & $\mathrm{~V}$ & 2 & $\mathrm{~F}$ & 0 \\
\hline \multicolumn{2}{|l|}{ Somatória } & & 10 & & 7 & & 14 & & 14 & & 6 \\
\hline \multicolumn{2}{|c|}{ V. de Desempenho } & \multicolumn{2}{|c|}{1,00} & \multicolumn{2}{|c|}{0,70} & \multicolumn{2}{|c|}{1,40} & \multicolumn{2}{|c|}{1,40} & \multicolumn{2}{|c|}{0,50} \\
\hline
\end{tabular}

Tabela 26 Resumo da Avaliação da Funcionalidade para Apartamentos T 4.

\begin{tabular}{|c|c|c|c|c|c|c|c|c|c|c|c|}
\hline & \multicolumn{2}{|c|}{7} & \multicolumn{2}{|c|}{12} & \multicolumn{2}{|c|}{18} & \multicolumn{2}{|c|}{19} & \multicolumn{2}{|c|}{49} \\
\hline \multicolumn{2}{|c|}{ Empreendımentos } & \multirow{2}{*}{$\mathrm{F} / \mathrm{V}$} & \multirow{2}{*}{$\begin{array}{l}\text { Ptos } \mathrm{x} \\
\text { Pond. }\end{array}$} & \multirow{2}{*}{$F / V$} & \multirow{2}{*}{$\begin{array}{l}\text { Ptos } \mathrm{X} \\
\text { Pond. }\end{array}$} & \multirow{2}{*}{ F/V } & \multirow{2}{*}{$\begin{array}{l}\text { Ptos } x \\
\text { Pond. }\end{array}$} & \multirow{2}{*}{$\mathrm{F} / \mathrm{V}$} & \multirow{2}{*}{$\begin{array}{l}\text { Ptos } \mathrm{x} \\
\text { Pond. }\end{array}$} & \multirow{2}{*}{$\mathrm{F} / \mathrm{V}$} & \multirow{2}{*}{\begin{tabular}{|c|} 
Ptos \\
$\mathrm{x}$ \\
Pond \\
\end{tabular}} \\
\hline Perguntas & Ponnd. & & & & & & & & & & \\
\hline 1 & 2 & $\mathrm{~V}$ & 2 & $\mathrm{~F}$ & 0 & $\mathrm{~V}$ & 2 & $\mathrm{~V}$ & 2 & $\mathrm{~V}$ & 2 \\
\hline 2 & 1 & $\mathrm{~V}$ & 1 & $\mathrm{~V}$ & 1 & $\mathrm{~V}$ & 1 & $\mathrm{~F}$ & 0 & $\mathrm{~V}$ & 1 \\
\hline 3 & 1 & $\mathrm{~V}$ & 1 & $\mathrm{~V}$ & 1 & $\mathrm{~V}$ & 1 & $\mathrm{~V}$ & 1 & $\mathrm{~V}$ & 1 \\
\hline 4 & 1 & $\mathrm{~V}$ & 1 & $\mathrm{~V}$ & 1 & $\mathrm{~V}$ & 1 & $\mathrm{~F}$ & 0 & $\mathrm{~V}$ & 1 \\
\hline 5 & 1 & $\mathrm{~F}$ & 0 & $\mathrm{~V}$ & 2 & V & 2 & $\mathrm{~F}$ & 0 & $\mathrm{~F}$ & 0 \\
\hline 6 & 1 & $\mathrm{~V}$ & 1 & $\mathrm{~F}$ & 0 & V & 1 & $\mathrm{~V}$ & 1 & $\mathrm{~V}$ & 1 \\
\hline 7 & 2 & V & 2 & $\mathrm{~V}$ & 2 & V & 2 & $\mathrm{~F}$ & 0 & $\mathrm{~F}$ & 0 \\
\hline 8 & 3 & $\mathrm{~V}$ & 2 & $\mathrm{~V}$ & 2 & $\mathrm{~V}$ & 2 & $\mathrm{~F}$ & 0 & $\mathrm{~F}$ & 0 \\
\hline 9 & 2 & $\mathrm{~F}$ & 0 & V & 2 & $\mathrm{~F}$ & 0 & $\mathrm{~F}$ & 0 & $\mathrm{~F}$ & 0 \\
\hline 10 & 1 & V & 1 & V & 1 & V & 1 & V & 1 & V & 1 \\
\hline 11 & 1 & $\mathrm{~F}$ & 1 & $\mathrm{~F}$ & 0 & $\mathrm{~F}$ & 0 & $\mathrm{~F}$ & 0 & V & 1 \\
\hline 12 & 2 & $\mathrm{~F}$ & 0 & V & 2 & V & 2 & V & 2 & V & 2 \\
\hline 13 & 2 & $\mathrm{~V}$ & 2 & $\mathrm{~V}$ & 2 & $\mathrm{~F}$ & 0 & $\mathrm{~F}$ & 0 & $\mathrm{~F}$ & 0 \\
\hline Somatória & & & 14 & & 16 & & 15 & & 7 & & 10 \\
\hline \multicolumn{2}{|c|}{ V. de Desempenho } & \multicolumn{2}{|c|}{1,40} & \multicolumn{2}{|c|}{1,60} & \multicolumn{2}{|c|}{1,50} & \multicolumn{2}{|c|}{0,70} & \multicolumn{2}{|c|}{1,00} \\
\hline
\end{tabular}


Tabela 26 (Continuação) Resumo Funcionalidade para Apartamentos T4

\begin{tabular}{|c|c|c|c|c|c|c|c|c|c|c|c|}
\hline \multicolumn{2}{|c|}{ Empreendimentos } & \multicolumn{2}{|c|}{113} & \multicolumn{2}{|c|}{165} & \multicolumn{2}{|c|}{166} & \multicolumn{2}{|c|}{167} & \multicolumn{2}{|c|}{168} \\
\hline & & $F / V$ & Ptos $x$ & $F / V$ & Ptos $x$ & $F / V$ & Ptos $x$ & $F / V$ & Ptos $x$ & $F / V$ & Ptos $\mathrm{x}$ \\
\hline Perguntas & Pond. & & Pond. & & Pond. & & Pond. & & Pond. & & Pond. \\
\hline 1 & 2 & $\mathrm{~V}$ & 2 & $\mathrm{~F}$ & 0 & $\mathrm{~V}$ & 2 & $\mathrm{~F}$ & 0 & $\mathrm{~V}$ & 2 \\
\hline 2 & 1 & $\mathrm{~V}$ & 1 & V & 1 & $\mathrm{~V}$ & 1 & $\mathrm{~V}$ & 1 & $\mathrm{~V}$ & 1 \\
\hline 3 & 1 & $\mathrm{v}$ & 1 & $\mathrm{v}$ & 1 & $\mathrm{v}$ & 1 & $\mathrm{~V}$ & 1 & $\mathrm{v}$ & 1 \\
\hline 4 & 1 & $\mathrm{~V}$ & 1 & $\mathrm{~F}$ & 0 & $\mathrm{~F}$ & 0 & $\mathrm{~V}$ & 1 & $\mathrm{~V}$ & 1 \\
\hline 5 & 1 & $\mathrm{~F}$ & 0 & $\mathrm{~F}$ & 0 & $\mathrm{~F}$ & 0 & $\mathrm{~V}$ & 2 & $\mathrm{~F}$ & 0 \\
\hline 6 & 1 & $\mathrm{~V}$ & 1 & $\mathrm{~F}$ & 0 & $\mathrm{~F}$ & 0 & $\mathrm{~V}$ & 1 & $\mathrm{~V}$ & 1 \\
\hline 7 & 2 & $\mathrm{~F}$ & 0 & $\mathrm{~F}$ & 0 & $\mathrm{~F}$ & 0 & $\mathrm{~V}$ & 2 & $\mathrm{~F}$ & 0 \\
\hline 8 & 3 & $\mathrm{~F}$ & 2 & $\mathrm{~V}$ & 2 & $\mathrm{~F}$ & 0 & $\mathrm{~V}$ & 2 & $\mathrm{~V}$ & 2 \\
\hline 9 & 2 & $\mathrm{~F}$ & 0 & $\mathrm{~F}$ & 0 & $\mathrm{~F}$ & 0 & $\mathrm{~F}$ & 0 & $\mathrm{~F}$ & 0 \\
\hline 10 & 1 & V & 1 & V & 1 & V & 1 & V & 1 & $\mathrm{~F}$ & 0 \\
\hline 11 & 1 & $\mathrm{~V}$ & 1 & $\mathrm{~F}$ & 0 & $\mathrm{~F}$ & 0 & $\mathrm{~V}$ & 1 & $\mathrm{~F}$ & 0 \\
\hline 12 & 2 & v & 0 & V & 2 & V & 2 & V & 2 & $\mathrm{~F}$ & 0 \\
\hline 13 & 2 & $\mathrm{~F}$ & 2 & $\mathrm{~V}$ & 2 & $\mathrm{~V}$ & 2 & V & 2 & $\mathrm{~V}$ & 2 \\
\hline Somatória & & & 12 & & 9 & & 9 & & 16 & & 10 \\
\hline V. de Des & npenho & & 20 & & 90 & & 0,90 & & 1,60 & & .00 \\
\hline
\end{tabular}

Gráfico 11 Variação do Valor de Desempenho da Funcionalidade em função da Área Privativa

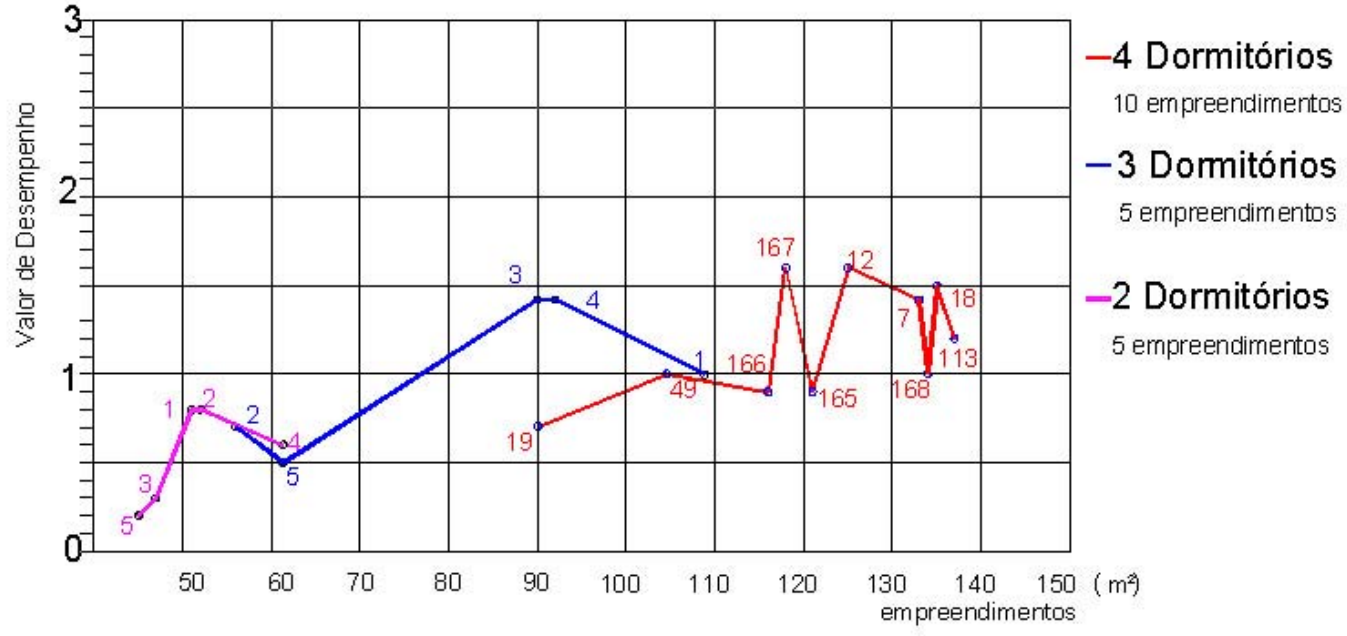




\subsubsection{Considerações sobre a Avaliação da Funcionalidade}

De acordo com os valores da tabela 24,25 e 26, podemos verificar que todas as plantas avaliadas estão abaixo do nível recomendável em relação ao ponto de vista funcionalidade, este fato se deve principalmente a falta de capacidade para abrigar os espaços de atividade dos equipamentos e mobiliário, nestes ambientes. Pode-se identificar este fato pelas respostas das perguntas $5,6,7,8$ e 9, dos elementos de avaliação

O gráfico 11 indica que a funcionalidade não é diretamente relacionada a variação da área privativa, como nos demais pontos de vista principalmente nos apartamentos de 3 e 4 dormitórios, como é o caso dos apartamentos de 2 dormitórios, ou seja, a partir de mais ou menos $90,00 \mathrm{~m}^{2}$ a funcionalidade depende do projeto proposto, da distribuição.

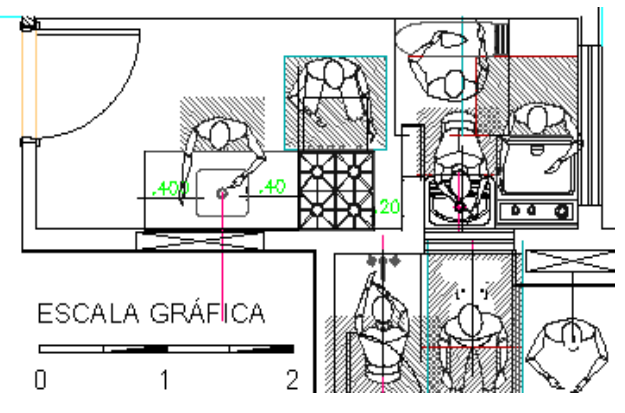

Fig. III 11 Desenho Funcionalidade Cozinha Empreendimento 2-T3

\begin{abstract}
A figura 11 demonstra que apartamentos de 3 dormitórios utilizam-se do mesmo dimensionamento usado nas cozinhas e áreas de serviço dos apartamentos de 2 dormitórios, ignorando a possibilidade da variação do número de usuários. Ocasionando o baixo valor de desempenho $(0,7)$ no elemento funcionalidade, aonde o mínimo é 1 (vide tabela 23).
\end{abstract}




\section{Aplicação do Método de Síntese dos Resultados}

Segundo os critérios de ponderação do MÉTODO, a adequação espaço funcional é responsável por 30\% da qualidade habitacional, de acordo com a seguinte ponderação:

Exigência de Uso = 100\%, composta da seguinte forma: 32\% Capacidade $+43 \%$ Espaciosidade $+25 \%$ Funcionalidade

\section{Capacidade}

Programa de Ambientes

Programa de Mobiliário

Extensão de Paredes

Mobiliáveis (não avaliado)
$32 \%$

\begin{tabular}{ll|l}
3 & 42 & \\
3 & 28 & $100 \%$ \\
3 & 30 &
\end{tabular}

Espaciosidade

Área Útil

Dimensão Útil

Pé direito (não avaliado) 18

\section{Funcionalidade}


A partir dos dados acima e como indica o METODO, foram calculados os valores para cada ponto de vista, por proporcionalidade, excluindo-se os subpontos de vista relativos à:

- paredes mobiliáveis e

- pé direito

Os quais não puderam ser avaliados através dos dados retirados das peças publicitárias. A proporcionalidade foi feita da seguinte forma;dos $100 \%$ de cada ponto de vista forma retirados os valores dos itens não avaliados, guardando a proporcionalidade, a saber:

\begin{tabular}{|c|c|c|}
\hline Capacidade & $(100-30) \times 0.01=0,70$ & $=22,40 \%$ \\
\hline Espaciosidade & $(100-18) \times 0.01=0,82$ & $=37,84 \%$ \\
\hline Funcionalidade & & $=25,00 \%$ \\
\hline & 100 & $=85,24 \%$ \\
\hline
\end{tabular}

Assim a porcentagem de cada ponto de vista fica da seguinte forma:

$\begin{array}{ll}\text { Capacidade } & .224 / .8524 \times 100=26,28 \% \\ \text { Espaciosidade } & .3784 / .8524 \times 100=44,39 \% \\ \text { Funcionalidade } & .2933 / .8524 \times 100=29,33 \%\end{array}$

O Valor de Desempenho Global será a média aritmética dos valores obtidos após a aplicação da ponderação, para cada grupo de qualidade. $(26,28+44,39+29,33)=100 \%$, que equivalem a $\Sigma 15$ de pontos. 


\subsection{Tabelas dos Valores de Desempenho}

As tabelas estarão em anexo (anexo 12) simplificadas para facilitar a leitura, mas constarão de forma completa, nos arquivos digitais, no anexo referido. Estas tabelas reunirão todos os pontos de vista para cada empreendimento concluindo no seu valor global de desempenho.

Tabela 27 Trecho da Tabela de Valor Global de Desempenhos para os empreendimentos 4 e 5 -T2

\begin{tabular}{|c|c|c|c|c|c|c|c|}
\hline & \multicolumn{3}{|c|}{ Empreendimentos } & \multirow{2}{*}{\multicolumn{2}{|c|}{$\begin{array}{c}4 \\
\left(61,66 \mathrm{~m}^{2}\right)\end{array}$}} & \multirow{2}{*}{\multicolumn{2}{|c|}{$\begin{array}{c}5 \\
45,54^{2}\end{array}$}} \\
\hline & \multirow{2}{*}{$\begin{array}{l}\text { Valor de } \\
\text { Máximo }\end{array}$} & \multirow{2}{*}{\multicolumn{2}{|c|}{\begin{tabular}{l}
\multicolumn{2}{c}{ Ponderação } \\
Ponto \\
de \\
Vista $\quad \%$ \\
\end{tabular}}} & & & & \\
\hline & & & & $\begin{array}{l}\text { Sub } \\
\text { Total }\end{array}$ & $\begin{array}{l}\text { Pond. } \\
2^{\mathrm{a}}\end{array}$ & $\begin{array}{l}\text { Sub } \\
\text { Total }\end{array}$ & $\begin{array}{l}\text { Pond } \\
2^{\mathrm{a}}\end{array}$ \\
\hline \multicolumn{8}{|l|}{ Capacidade } \\
\hline Programa de Ambientes & 3 & 0,56 & & & & & \\
\hline \multirow{2}{*}{ Programa de Mobiliário } & 3 & 0,44 & & & & & \\
\hline & & & 26,28 & 1,28 & & 1,09 & \\
\hline V. de D. -Capacidade & & & & & 0,34 & & 0,29 \\
\hline \multicolumn{8}{|l|}{ Espaciosidade } \\
\hline Área Útil & 3 & 0,48 & & & & & \\
\hline \multirow[t]{2}{*}{ Dimensão Útil } & 3 & 0,52 & & & & & \\
\hline & & & 44,39 & 1,10 & & 0,50 & \\
\hline V. de D. Espaciosidade & & & & & 0,49 & & 0,22 \\
\hline \multicolumn{8}{|l|}{ Funcionalidade } \\
\hline V de D. Funcionalidade & 3 & 1 & 29,33 & 0,18 & 0,05 & 0,06 & 0,02 \\
\hline$\%$ & & & 100 & & & & \\
\hline $\begin{array}{l}\text { Valor de Desempenho } \\
\text { Global }\end{array}$ & & & & & 0,88 & & 0,53 \\
\hline
\end{tabular}

\subsection{Gráfico Comparativo Global dos Valores de Desempenho}

O gráfico abaixo, representa os valores de cada empreendimento, dentro da escala de 1 a 3. Aonde 1 é mínimo, 2 é recomendável e 3 é ótimo. 


\subsection{Gráfico Comparativo Global}

Gráfico 12 Comparativo Global dos Valores de Desempenho por Área Privativa

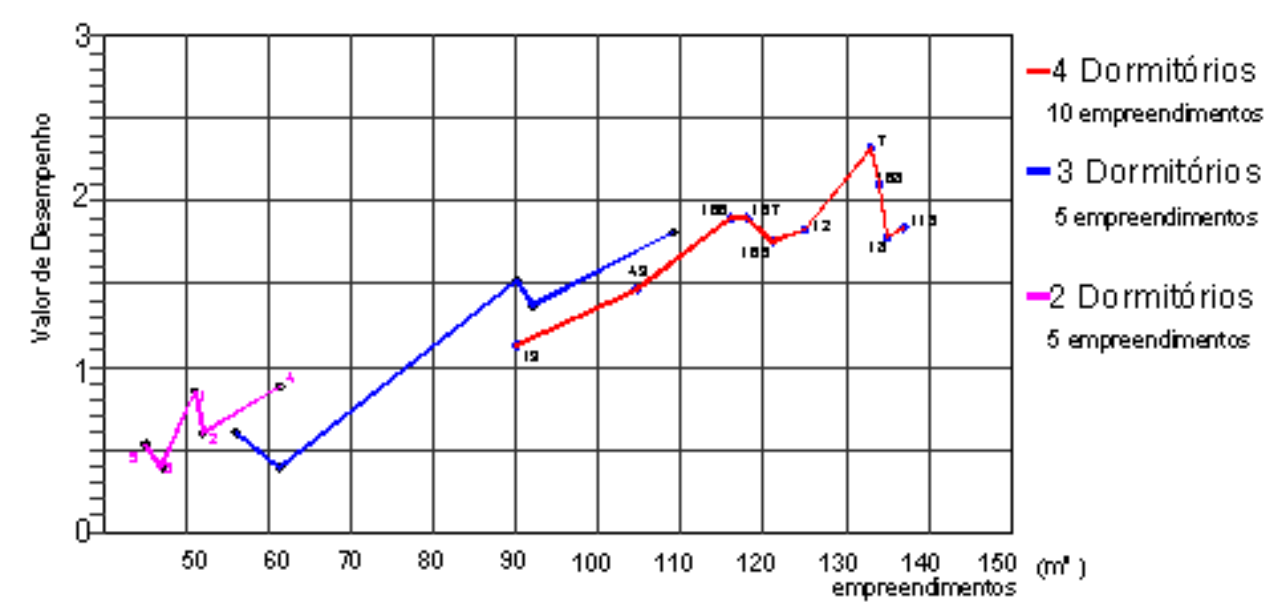

\subsection{Análise dos Resultados}

3.3.1. A Variação do Valor de Desempenho Global em Função da Área

Privativa, Dentro da Adequação Espaço Funcional.

Os Valores de Desempenho, em função da área privativa, representados no gráfico 12 , podem ser estudados de forma isolada para cada tipologia, ou em conjunto, a saber:

- A qualidade do espaço nos apartamentos de 2 dormitórios, está vinculada à área privativa, em praticamente todos pontos de vista. Os valores apresentados estão abaixo do mínimo, foi adotada referência "valor nulo", para auxiliar na análise dos resultados.

- Os apartamentos de 3 dormitórios já mostram uma evolução do valor de desempenho ainda relacionada ao aumento da a área privativa, porém, 
dependendo mais do projeto, vide os empreendimentos 3 e o 4 (T3) têm uma variação muito pequena de área em relação à variação de desempenho. Nesta tipologia os dois valores apresentam um intervalo de variação maior que na T2. - Os apartamentos de 4 dormitórios compactuam da análise das demais tipologias, no entanto, o aumento da área nem sempre melhora a condição dos valores de desempenho como um todo, únicos a ultrapassar o recomendável, em função da área e únicos a atingir o mínimo dentro das condições adotadas no método.

3.3.2. Variação do valor de desempenho global em função dos demais pontos de vista

Os quadros resumo, por tipologia retratam :

- A baixa pontuação da funcionalidade, é uma característica de todos os apartamentos, principalmente nos apartamentos de 2 e 3 dormitórios.

- Quanto a espaciosidade a dimensão útil foi o ponto de vista melhor pontuado em todos os empreendimentos, o que se contrapõe a funcionalidade.

- A capacidade de suportar mobiliário e equipamentos, programas de mobiliário e equipamentos, fica acima do mínimo em todos os empreendimentos, mas o resultado obtido para os apartamentos de 2 dormitórios se mantém dentro do valor mínimo,ou seja, entre 1 e abaixo de 1,5 dentro da escala adotada pelo do METODO que é de 1 a 3.

Verifica-se que dentro dos critérios estabelecidos e com a ponderação adotada, é notável o baixo desempenho dos apartamentos de 2 dormitórios, os apartamentos de 4 dormitórios, estão todos acima do mínimo (não quer dizer 
que são ótimos), o que pode demonstrar que o estudo da habitação dentro das condições mínimas ainda é atual e necessário. Os apartamentos do universo estudados tiveram como critério de escolha os empreendimentos financiados pela CEF na tipologia de 2 dormitórios, inseridas no sistema de crédito imobiliário denominado crédito associativo, o qual requer uma renda familiar de aproximadamente $\mathrm{R} \$ 4.000,00$ (quatro mil reais), pode-se dizer que se estão no mercado é por que estão sendo comercializados, conclui-se que; ou o comprador desta faixa de renda ainda não filtra estes dados, caso contrário não compraria um apartamento aonde sofre restrições na hora da compra do mobiliário e equipamentos ou não tem outras opções no mercado. A pesquisa indica que a responsabilidade por este seguimento ainda é da equipe que gera os empreendimentos estando entre eles os incorporadores, os construtores, os projetistas e principalmente o agente financeiro que provê os recursos. Concluindo que esta realidade só poderá ser alterada com uma maior conscientizarão do público comprador, no ato de optar por um ou outro empreendimento até que a velocidade de vendas (a liquidez) justifique a diferença de área e de preço. A pesquisa não conclui sobre custo de construção apenas cita a área privativa como fator indexador do preço dos apartamentos estudados. 


\section{Qualidade dos Ambientes da Habitação segundo Prof. Dr.}

\section{BOUERI (2001) Avaliação dos Índices Ergonômicos}

Utilizando-se os Índices de Avaliação Ergonômica do Dimensionamento da Habitação, apresentados pelo Prof. Dr. BOUERI, J.J. no Congresso Abergo 2005, conforme exposto no Capítulo II (pág. 24) desta pesquisa, obtivemos os valores representados nas tabelas 28,29 e 30 :

Tabela 28 Resumo Índices Ergonômicos Apartamentos T2 Fonte: autor

\begin{tabular}{|l|c|c|c|c|c|c|c|c|c|c|}
\hline & \multicolumn{2}{|c|}{1} & \multicolumn{2}{c|}{2} & \multicolumn{2}{c|}{3} & \multicolumn{2}{c|}{4} & \multicolumn{2}{c|}{5} \\
\hline & H. FLEX & \multicolumn{2}{c|}{ SPAZIO } & \multicolumn{2}{c|}{ ECO 2 } & \multicolumn{2}{c|}{ MOOCA } & \multicolumn{2}{c|}{ ECO 1 } \\
\hline & & & & & & & & & & \\
\hline & & 1,00 & & 2,00 & & 1,00 & & 3,00 & & 1,00 \\
\hline AEDH1 & PR & & R & & PR & & S & & PR & \\
\hline MÉDIA & & 1,50 & & 1,67 & & 1,67 & & 2,00 & & 1,67 \\
\hline AEDH2 & PR & & PR & PR & R & & & R & & R \\
\hline MÉDIA & & 1,50 & & 2,00 & & 1,33 & & 1,86 & & 1,00 \\
\hline AEDH3 & PR & & R & & PR & & R & & PR & \\
\hline & & & & & & & & & & \\
\hline Total & & 1,33 & & 1,89 & & 1,33 & & 2,29 & & 1,22 \\
\hline Conceito Geral & & PR & & PR & & PR & & R & & PR \\
\hline
\end{tabular}

\begin{tabular}{lcc}
\multicolumn{3}{l}{ Critério de Avaliação } \\
Bom & B & 4 \\
\hline Satisfatório & S & 3 \\
\hline Regular & R & 3 \\
\hline Precário & PR & 1 \\
\hline
\end{tabular}

Tabela 29 Resumo - Índices Ergonômicos Apartamentos T3 Fonte: Autor

\begin{tabular}{|c|c|c|c|c|c|c|c|c|c|c|}
\hline & \multicolumn{2}{|c|}{1} & \multicolumn{2}{|c|}{2} & \multicolumn{2}{|c|}{3} & \multicolumn{2}{|c|}{4} & \multicolumn{2}{|c|}{5} \\
\hline & \multicolumn{2}{|c|}{ DIANA } & \multicolumn{2}{|c|}{ SPAZIO } & \multicolumn{2}{|c|}{ B.S.FRAN. } & \multicolumn{2}{|c|}{ MOOCA } & \multicolumn{2}{|c|}{ CITY } \\
\hline & & 4,00 & & 1,00 & & 3,00 & & 4,00 & & 2 \\
\hline AEDH1 & B & & PR & & S & & B & & $\mathrm{R}$ & \\
\hline MÉDIA & & 2,40 & & 1,43 & & 1,44 & & 1,56 & & 1,11 \\
\hline AEDH2 & $\mathrm{R}$ & & PR & & PR & & PR & & PR & \\
\hline MÉDIA & & 2,40 & & 1,70 & & 2,00 & & 2,00 & & 1,25 \\
\hline AEDH3 & $\mathrm{R}$ & & $\mathrm{R}$ & & $\mathrm{R}$ & & $\mathrm{R}$ & & $\mathrm{R}$ & \\
\hline Total & & 2,93 & & 1,38 & & 2,15 & & 2,52 & & 1,453 \\
\hline Conceito Geral & & $\mathbf{R}$ & & PR & & $\mathbf{R}$ & & $\mathbf{R}$ & & PR \\
\hline
\end{tabular}


A área útil dos apartamentos de 2 dormitórios (AEDH1), é o item que mais influencia no Conceito Geral como Precário destes apartamentos. Fica evidente que o desempenho cai abaixo dos $50,00 \mathrm{~m}^{2}$ de área privativa o que corresponde a aproximadamente $42,00 \mathrm{~m}^{2}$ de área útil, considerando-se uma lotação de 4 pessoas, se enquadram na faixa de área de 10,00 a $8,00 m^{2} /$ habitante, vide Tabela 01, capítulo II (pág. 24), resultando em conceito precário, pelo critério de ponderação adotado.

Tabela 30 - Resumo Índices Ergonômicos Apartamentos T4. Fonte autor

\begin{tabular}{|c|c|c|c|c|c|c|c|c|c|c|}
\hline & \multicolumn{2}{|c|}{$\begin{array}{c}7 \\
\text { DREAM }\end{array}$} & \multicolumn{2}{|c|}{$\begin{array}{c}12 \\
\text { BALTIMORE }\end{array}$} & \multicolumn{2}{|c|}{ INDEP. } & \multicolumn{2}{|c|}{$\begin{array}{c}19 \\
\text { J. LUX }\end{array}$} & \multicolumn{2}{|c|}{$\begin{array}{c}49 \\
\text { GENEVE }\end{array}$} \\
\hline & & 4,00 & & 3,00 & & 2,00 & & 2,00 & & 3,00 \\
\hline AEDH1 & PR & & $S$ & & $\mathrm{R}$ & & $\mathrm{R}$ & & $\mathrm{S}$ & \\
\hline MÉDIA & & 1,69 & & 1,69 & & 1,62 & & 1,45 & & 1,73 \\
\hline AEDH2 & PR & & PR & & PR & & PR & & PR & \\
\hline MÉDIA & & 2,08 & & 2,08 & $\mathrm{~S}$ & 3,25 & & 1,55 & & 2,00 \\
\hline AEDH3 & PR & & $\mathrm{R}$ & & & PR & PR & & $\mathrm{R}$ & \\
\hline $\begin{array}{l}\text { Total } \\
\text { Conceito Geral }\end{array}$ & & \begin{tabular}{|c|}
2,59 \\
$R$
\end{tabular} & & $\begin{array}{c}2,26 \\
\mathbf{R}\end{array}$ & & $\begin{array}{c}2,29 \\
R\end{array}$ & $\mathbf{R}$ & 1,67 & $\mathbf{R}$ & 2,24 \\
\hline
\end{tabular}

Tabela 30 - Resumo Índices Ergonômicos Apartamentos T4 (continuação)

\begin{tabular}{|c|c|c|c|c|c|c|c|c|c|c|}
\hline & \multicolumn{2}{|c|}{$\begin{array}{c}113 \\
\text { CLASSIC }\end{array}$} & \multicolumn{2}{|c|}{$\begin{array}{c}165 \\
\text { PREMIERE }\end{array}$} & \multicolumn{2}{|c|}{$\begin{array}{c}166 \\
\text { ARANDU }\end{array}$} & \multicolumn{2}{|c|}{$\begin{array}{c}167 \\
\text { ECOLIFE }\end{array}$} & & $\begin{array}{c}168 \\
\text { PIAZZA }\end{array}$ \\
\hline & & 3,00 & & 3,00 & & 3,00 & & 3,00 & & 3,00 \\
\hline AEDH1 & S & & S & & S & & S & & S & \\
\hline MÉDIA & & 2,60 & & 1,75 & & 1,83 & & 1,85 & & 1,92 \\
\hline AEDH2 & $\mathrm{R}$ & & PR & & PR & & PR & & PR & \\
\hline MÉDIA & & 2,85 & & 2,17 & & 2,33 & & 2,62 & & 2,31 \\
\hline AEDH3 & $\mathrm{R}$ & & $\mathrm{R}$ & & $\mathrm{R}$ & & $\mathrm{R}$ & & $\mathrm{R}$ & \\
\hline $\begin{array}{l}\text { Total } \\
\text { Conceito Geral }\end{array}$ & $\mathbf{R}$ & 2,82 & $\mathbf{R}$ & 2,31 & $\mathbf{R}$ & 2,39 & $\mathbf{R}$ & 2,49 & $\mathbf{R}$ & 2,41 \\
\hline
\end{tabular}


Os apartamentos de 3 dormitórios, são realmente os representantes do estágio intermediário, segundo a avaliação do método, possuindo dois empreendimentos com conceito precário(P), os empreendimentos 2 e 5 , contra 3 regulares (R). O item que mais influenciou na pontuação baixa foi a área útil dos ambientes (AEDH2), enquanto os de 4 dormitórios são todos regulares. Muitos destes resultados, da tipologia T4, poderiam variar,alterando-se o critério de análise dos banheiros, por exemplo, incluindo um lavabo na lista de análise aonde as funções e atividades são diminuídas em relação aos banheiros sociais.

\section{Síntese do Capítulo}

O universo de apartamentos avaliados foi de 20 , sendo 10 de T4 (4 dormitórios), 5 de T3 (3 dormitórios) e 5 de T2 (2 dormitórios). A média encontrada, segundo PEDRO (2003) por tipologia na escala de 1 a 3 foi:

$\mathrm{T} 4$ valor de desempenho global $=1,78$

T3 valor de desempenho global $=1,14$

$\mathrm{T} 2$ valor de desempenho global $=0,65$

Quanto a avaliação das dimensões encontrada nos compartimentos, destacamos os dormitórios e os banheiros sociais. Nos dormitórios a grande maioria teve a pontuação diminuída pois não há espaço para a arrumação das camas, ou seja o ambiente não comporta o movimento da pessoa curvada para exercer esta atividade, ficando ainda mais agravada a capacidade de comportar o mobiliário e os equipamentos, neste caso, ressaltamos a cadeira/poltrona e a televisão que são itens constantes na listagem do INVENTÁRIO, como almejado dentro dos dormitórios. A figura 12 abaixo (BOUERI 2004), demonstra o espaço necessário para a atividade de arrumação da cama com a movimentação do corpo em três níveis de qualidade dimensional, a saber : 
Nível mínimo

- Nível recomendado

Nível ótimo.

Fig. III 12 Cama de Casal

Aplicações Dimensionais

Fonte BOUERI 2004 Tese de

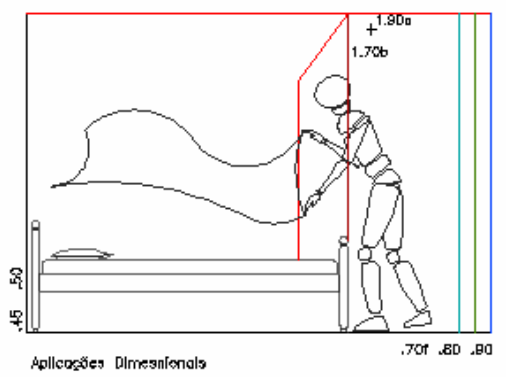
Livre Docência

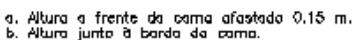

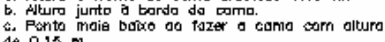
dit $0.15 \mathrm{~m}$.

A qualidade destes ambientes foi avaliada nos itens funcionalidade, segundo PEDRO e na composição de mobiliário e equipamento, segundo BOUERI, encontramos na maioria dos apartamentos o espaço restrito prejudicado invadindo parede oposta a cabeceira da cama ou aos armários, como verificado na figura 10 desenho deste capítulo pág. 41.

Quanto aos banheiros a figura 13 representa o tipo de disposição mais encontrado nos apartamentos levantados no INVENTÀRIO, fazendo parte de trabalho programado do autor, aonde o espaço à frente da bacia é um dos fatores da baixa pontuação nas duas avaliações realizadas.O número abaixo das tipologias representa a incidência deste arranjo em cada uma delas, as bacias com caixa acoplada são padronizadas eo aumento de área para enquadrar no uso restrito seria ínfimo, melhorando a usabilidade destes banheiros.

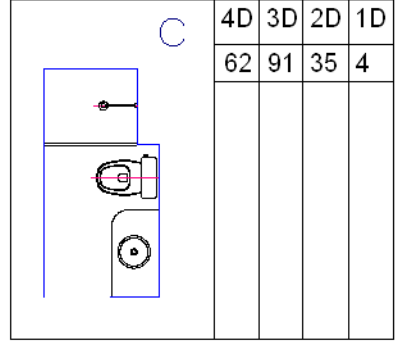

Fig. III 13 Cama de Casal Aplicações Dimensionais Fonte: Autor

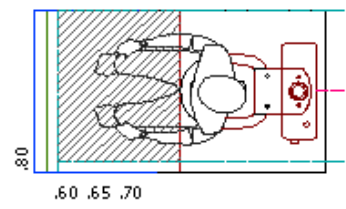

Fig. III 14 Bacia

Aplicações Dimensionais

Fonte: BOUERI, com alterações do autor, inclusão de caixa de descarga acoplada 


\section{Considerações Finais}

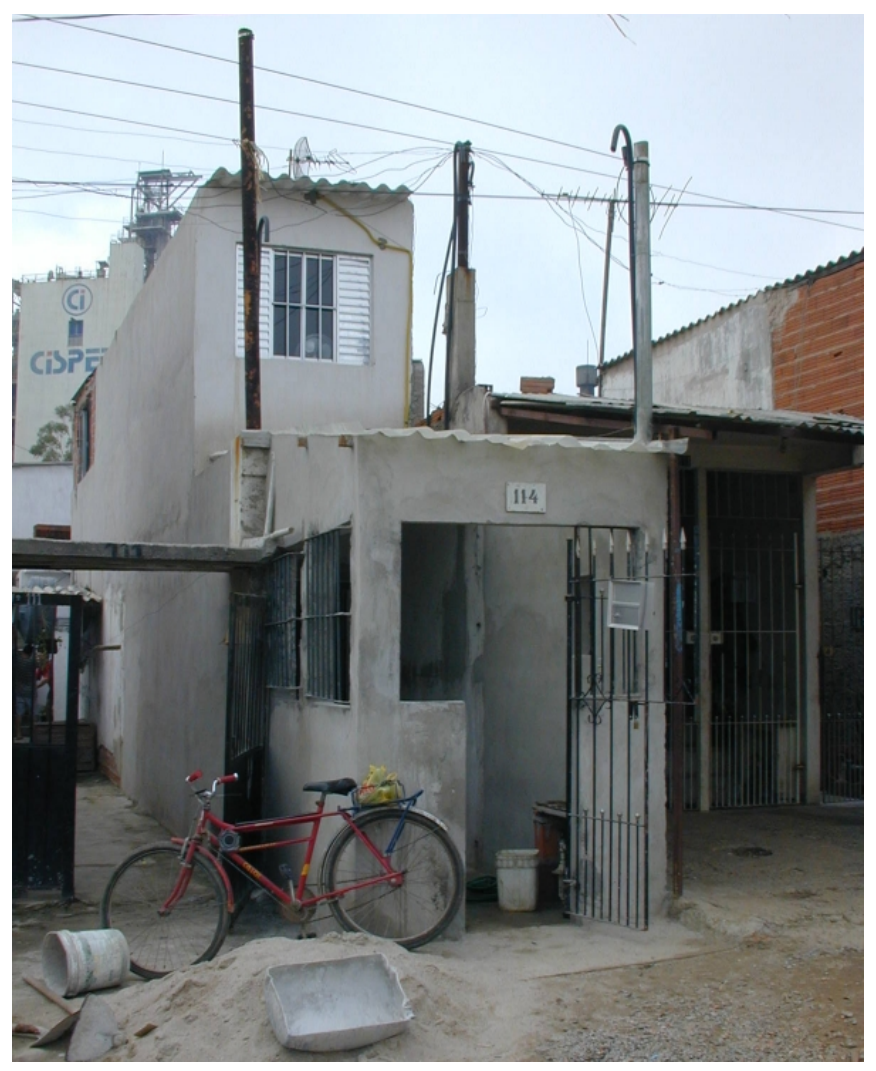

Fonte autor 17/12/2003

Casa com largura total de $1,60 \mathrm{~m}$. vizinho de fundos USP LESTE 


\section{Considerações Finais}

Esta pesquisa buscou uma série de informações sobre o estudo da qualidade do dimensionamento habitacional nos apartamentos na cidade de São Paulo; as respostas a estas questões são as considerações finais desta pesquisa, quais sejam:

- A possibilidade de identificar o modo de vida (hábitos e costumes) dos moradores, utilizando as tipologias dos apartamentos e a composição do mobiliário e dos equipamentos representados nos desenhos publicitários como indicadores das necessidades e / ou inovações nos programas de ambientes dos apartamentos na cidade de São Paulo.

A pesquisa demonstra as necessidades dos programas de ambientes dos apartamentos estudados e identifica as preferências básicas por tipologia através das atividades sugeridas pelo mobiliário e equipamentos. (Vide Inventário BOUERI FAPESP). No entanto, o baixo valor de desempenho da qualidade dimensional dos apartamentos do universo estudado, especialmente os de dois dormitórios, sugere que os mesmos não comportem a lotação indicada pelas camas desenhadas, premissa adotada nesta pesquisa para o cálculo de lotação das habitações. 
- Como se quer viver ou como se quer demonstrar que vive. A compartimentação como necessidade ou como valor simbólico?

Nos exemplos estudados, os apartamentos apresentam uma compartimentação (aumento de ambientes) sem aumento da área privativa, ou seja, os apartamentos de quatro dormitórios podem possuir a mesma área privativa que os de três dormitórios e assim por diante, provavelmente para manter o valor de venda do apartamento, oferecendo como vantagem um outro dormitório que compromete a qualidade de dimensionamento dos ambientes como um todo. Seguindo este raciocínio e fazendo-se uma analogia ao assunto tratado por LOUREIRO e AMORIM (2005), no texto "Dize-me teu nome, tua altura e onde moras e te direi quem és: Estratégias de marketing e a criação da casa ideal - parte 1", quando aborda a localização dos apartamentos nas áreas urbanas, onde "uma das regras de ouro é:

...a divisão simbólica da cidade, que classifica socialmente as pessoas segundo sua localização no espaço da cidade, "... ${ }^{1}$

pode-se dizer que da mesma forma que as pessoas se sentem classificadas socialmente com mais prestígio social morando em um apartamento de vários dormitórios, sendo

"fundamental para definir o status dos indivíduos, atribuindoIhes mais ou menos vantagens ou privilégios que são, basicamente, as oportunidades de acesso a determinados padrões materiais ou não-materiais". ${ }^{2}$

\footnotetext{
${ }^{1}$ LOUREIRO, Claudia e AMORIM, Luiz, (professores da Universidade Federal de Pernambuco) texto 281 02/2005 -título do artigo -site vitruvius

${ }^{2}$ VELHO, G. p. 811975 A utopia urbana: um estudo de antropologia social. $2^{\mathrm{a}}$ ed. Rio de Janeiro: Zahar Editores, .apud Op. cit.,1
} 
"Afinal, a casa, tal como outras posses, é um indexador de status social e de poder de compra do indivíduo." ${ }^{3}$

Muito pequenos e que não comportam as atividades necessárias, pode-se dizer que os apartamentos de dois dormitórios estão abaixo dos limites mínimos estabelecidos pelos dois tipos de avaliação utilizados, não desempenhando a função de moradia com dignidade de acordo com as avaliações realizadas. Talvez desempenhem função de abrigo, segundo RYWERT, J. $^{4},(2003)$ quando questiona se a construção da primeira cabana pelo homem foi ou não uma obra de arquitetura.

"Embora Quatremère acredite que esta cabana tenha realmente existido, ela consiste meramente em um produto das circunstâncias naturais: a imitação desse modelo "natural" não eleva a edificação ao status da arquitetura.

Foi emulando a natureza pela adoção das proporções do corpo humano que os primitivos construtores gregos elevaram seu ofício ao status de grande arte."

Esta citação faz referencia ao tema da pesquisa, ou seja, só teremos qualidade na habitação, quando forem respeitados os limites do corpo humano.

Os apartamentos com este dimensionamento abaixo do conceito restrito (BOUERI, 2001) buscam atender primordialmente as chamadas necessidades básicas citadas por SCRUTON (2003) $)^{5}$ quando menciona o homem como ser dualista possuidor de necessidades básicas provenientes da

\footnotetext{
${ }^{3}$ Hanson, J. 1998 Decoding homes and houses. Cambridge University Press, apud Loureiro e Amorim , Op. Cit 1.

${ }^{4}$ RYKWERT, Joseph pág. 33- A casa de Adão no Paraíso, 2003.São Paulo Editora Perspectiva.
} 
sua natureza animal (como comida e abrigo) e necessidades do homem racional, acreditando que sejam estas últimas que devam ser priorizadas ,

"Se é que o conceito de uma necessidade nos leva a algum ideal de <projeto racional>

seguindo, o autor cita que estas não são suficientes para completar a natureza dualista do homem. Talvez uma análise desses apartamentos após cinco anos possa fornecer maiores dados para pesquisa.

\section{- Quais os pontos de maior concentração de área nos apartamentos?}

A maior concentração de área está na zona íntima, vide tabela no anexo 5, onde se desenvolvem as atividades de descanso, repouso, lazer, atividades dos jovens e etc... ${ }^{6}$, enfim na zona de abrigo.

Levando-se em consideração os elementos de pesquisa levantados no capítulo I, a zona íntima da casa estava relacionada historicamente com as atividades desenvolvidas pelas mulheres, exercendo as funções de mãe, educadora, reprodutora, consumidora, enquanto para o homem ficava o setor público (que foi chamada de zona social nesta pesquisa), o trabalho, a reprodução, a razão, a ciência, a cultura, a política e a atividades extra-muros. Estas funções e atividades eram desenvolvidas em ambientes específicos, a saber:

- Mulher: a sala da senhora, entre a zona de serviços e a sala de jantar e de visitas, ou seja, um estar informal ou íntimo, lembrando as atividades descritas

\footnotetext{
${ }^{5}$ SCRUTON, Roger pág. 38, 1983 Estética da Arquitetura Livraria Martins Fontes São Paulo.

${ }^{6}$ anexo 8 - funções e sistema de atividades na moradia
} 
nas casas gregas onde tínhamos o "Oecus" e da casa islâmica aonde a mulher tinha uma sala (iwan) para receber pessoas próximas.

- Homem: os gabinetes, com entrada independente, o "fumoir", o bilhar e a biblioteca.

O conceito de zona íntima ou privada é muito diferente do citado historicamente:

" o que hoje chamamos de privado é um circulo de intimidades cujos primórdios podemos encontrar nos últimos períodos da civilização romana, ...., mas cujas peculiaridades multiformidades e variedade eram certamente desconhecidas de qualquer período anterior à era moderna"...... fato histórico decisivo é que a privatividade moderna, em sua função mais relevante - proteger aquilo que é íntimo - foi descoberta não como os opostos da esfera política, mas da esfera social. Com a qual, portanto, tem laços mais estreitos e mais autênticos."”

- É possível prever ou pesquisar os programas e as reais necessidades nas habitações da sociedade do século XXI, facilitando assim o estudo do seu dimensionamento?

A pesquisa não pôde prever, somente pôde constar através das ferramentas utilizadas que, para que se possam dimensionar as mudanças nos espaços das futuras habitações, a utilização do MÉTODO e dos DESENHOS DOS ESPAÇOS DE ATIVIDADES, por terem sido fundamentados no corpo e comportamentos humanos, poderão servir de instrumental para avaliações dos

\footnotetext{
${ }^{7}$ Arendht, Hannah, pág. 481981 "A Condição Humana" ed. USP
} 
espaços destinados a futuras atividades que venham a surgir no âmbito doméstico.

- O objeto de pesquisa foi a qualidade dos apartamentos de quatro dormitórios lançados no mercado no seu quesito dimensional, comparando-os com as tipologias de três e dois dormitórios. O que foi encontrado?

O encontrado de certa forma foi frustrante, dado o nível baixo da avaliação da maioria dos apartamentos. Os apartamentos de quatro dormitórios não estão incluídos na categoria da habitação mínima, não tendo o custo como resposta para todos os elementos negativos apresentados. O projeto influencia mais esta tipologia, este fator fica representado pelo desempenho desfavorável da funcionalidade e favorável da dimensão útil encontrada na avaliação destes pontos de vista ${ }^{8}$. A média da qualidade dimensional encontrada na tipologia T4, foi 1,78 em uma escala de 1 a 3 (entre o mínimo e o recomendável), segundo PEDRO (2003) e 2,35 (regular) em uma escala de 1 a 4 segundo BOUERI (2001).

Nota-se que a lotação dos apartamentos como apresentada nas peças publicitárias não é respeitada. O fato pode ser ilustrado na avaliação do índice ergonômico de densidade (Área Útil da Habitação -AEDH1) ${ }^{9}$, especialmente nos apartamentos de três e quatro dormitórios, os quais apresentam uma tipologia e possuem o dimensionamento dos ambientes, especialmente cozinhas e banheiros dos apartamentos de dois dormitórios.

\footnotetext{
${ }^{8}$ pág. 16, capítulo II desta pesquisa.
} 
- A pergunta que fica é por que o mercado consumidor continua aceitando (comprando) estes apartamentos. Por falta de opção? Por falta de conhecimento? Ou porque as tipologias das famílias e seus hábitos estão mudando e a necessidade de compartimentação está fazendo parte de um processo de alterações comportamentais em andamento?

Os apartamentos em questão foram a mercado e dependiam da aceitação do público, não são de interesse social e no entanto, muitas vezes têm qualidade dimensional abaixo destes últimos, fato que pode ser ilustrado no artigo ABERGO 2005, onde foram avaliados os índices ergonômicos de apartamentos como o Conjunto Habitacional União da Juta - Sapopemba - SP 1984 a 2000, que obtiveram um conceito melhor que qualquer um dos cinco empreendimentos de dois dormitórios avaliados por esta pesquisa.

Finalizando com uma frase de FORTER ${ }^{10}$, pode-se dizer que os projetos que levaram em consideração o corpo humano podem ter os usos transformados que continuarão possuindo capacidade dimensional para abrigar atividades humanas, pois "sobrevivem a si mesmo e a sua função".

Assim o estudo de Vitruvius, os de Le Courbisier muitos anos mais tarde, e os demais estudos que têm como base o corpo humano (antropometria e ergonomia) sempre serão atuais.

A capacitação baseada no conhecimento das necessidades espaciais do corpo humano e no uso deste como fator determinante da concepção de espaços traduz a intenção de garantir ao projeto sua usabilidade através da

\footnotetext{
${ }^{9}$ Pag. 52 e 53 Capítulo III desta dissertação.

${ }^{10}$ Texto original de Marisa Barda, para a revista AU 129 - dezembro de 2004.
} 
ciência e da técnica, reservando-se a outras disciplinas as abordagens intuitivas da forma e da estética.

O estudo da qualidade dimensional e de forma análoga, o ensino do dimensionamento com bases ergonômicas são ferramentas de trabalho para o projeto de arquitetura lastreada em bases científicas. A sua utilização por profissionais da área de construção é diversificada e atinge diferentes áreas de atuação, entre elas: arquitetos em exercício da profissão (autores de projetos) e profissionais que analisam projetos, desempenhando cargos em instituições financeiras e órgãos públicos promotores de habitações.

A avaliação da qualidade dimensional poderá ser de uso de toda a sociedade da forma que foi utilizada nesta pesquisa, pois é de fácil compreensão e adequação às reais necessidades dos futuros usuários. 


\section{Referências Bibliográficas}

A bibliografia é constituída basicamente de livros, manuais, apostilas, pesquisas (teses), revistas e periódicos, fonte para a caracterização do objeto deste estudo, visando a estrutura metodológica a ser empregada.

\section{Bibliografia Comentada}

1. BOUERI, Jorge - Antropometria Fator de Dimensionamento da Habitação, São Paulo, Tese (Doutorado) FAU USP, 1989.

"O homem apresenta ao redor de si, uma gama de bolhas invisíveis que se expandem e se contraem, dependendo do seu estado emocional, sua cultura, suas atividades e do seu status social".

O estudo da ergonomia, levando-se em consideração os aspectos humanos, como; ciclo de vida, formas de ocupação do espaço com o mobiliário e os hábitos, costumes muitos outros, ajudam no dimensionamento habitacional.

2. KLEIN, Alexandre - La Vivenda Mínima:1906-1957, Barcelona, Gustavo Gili, 1980.

"A organização do espaço e seu uso estão estruturados baseada em dados antropométricos, determinando assim a identidade de uma habitação." Este ator desenvolveu um método de dimensionamento importante, também chamado método gráfico de Klein , a habitação deve traduzir tranqüilidade e garantia de repouso e recuperação das energias gastas no trabalho.

"a definição da habitação mínima não deveria significar um empobrecimento nas condições de habitabilidade". 
3. ARGAN, Giulio Carlo - Projeto e Destino, Editora Ática,2001.

"A arquitetura entendida como ambiente de um drama psicológico, não permite a formulação nítida de princípios figurativos, aliás a própria substituição do plástico pelo pictórico".-(pg. 183). Quando cita, "que uma casa sem identidade...coloca o morador em um cenário", realça o aspecto psicológico do estudo da habitação. A visão deste filósofo e prefeito romano coloca um pouco de reflexão e poesia no entendimento do espaço habitacional.

4. SCHOENAUER, Norbert $-\underline{6,000}$ Years of Housing, Norton and Company New York-London ,1981.

A análise histórica dos 6000 anos da habitação, com referencias de escala, nas plantas apresentadas, pode ajudar, explicar e dirimir muitos questionamentos sobre a evolução dimensional.Base para o Trabalho Programado 1 - Evolução Histórica da Função, Uso e Dimensões dos Ambientes da Habitação - 6000 anos.

5. RYKWERT, -J. A Casa de Adão.; Editora Perspectiva.pág. 66, 1981. "Enquanto os gregos teriam evoluído para a madeira criando a verdadeira arquitetura antiga os egípcios por falta de madeira em seu território teriam saltado para a pedra e o mármore,...."

6. LEMOS, Carlos A. C. - Cozinha, etc. São Paulo, Perspectiva, 1978.

"Podemos dizer que hoje a televisão e fogão constituem os 2 centros de interesse da vida domiciliar cotidiana". Neste maravilhoso trabalho temos uma pesquisa de dimensionamento das residências paulistas.

7. LEMOS, Carlos A.C. - Casa Paulista, São Paulo, Edusp,1999.

"Para o presente estudo é importante ressaltar os aspectos comportamentais como a segregação feminina e o exercício de das práticas religiosas, a primeira sendo responsável por 2 zonas distintas nas casas, a íntima aonde se vivia e a de receber, a hospitalidade era uma obrigação social devido as grandes distancias e a morosidade dos meios de locomoção." Desta obra pudemos 
retirar a evolução dimensional, das casas paulistas anteriores ao ecletismo trazido pela economia cafeeira.

8. SAMPAIO, Maria Ruth Amaral - Promoção Privada de Habitação Econômica e a Arquitetura Moderna 1930-1964, São Carlos, Rima Editora, 2002.

Esta obra norteia o tipo de pesquisa sobre habitação coletiva na cidade de São Paulo. O levantamento completo realizado, possui plantas com escala gráfica, aonde pode-se constatar a dimensão de compartimentos considerados básicos, já que os apartamentos de 4 dormitórios não foram o foco deste trabalho.

9. HOMEM, Maria Cecília Naclério - "O Palacete Paulistano e Outras Formas Urbanas de Morar da Elite Cafeeira" -São Paulo,Editora Martins Fontes, 1996.

"Os programas das casas mais abastadas, bem como o modo de vida de seus dos moradores, resultaram da superposição do processo civilizador urbano associado a civilização rural pré-existente, que prevaleceu até 1888 " Deste livro e da sua pesquisa de doutorado, foram retirados dados importante de como eram distribuídas as áreas e as zonas dos palacetes paulistanos, muito hoje substituídos por apartamentos de área superior a 750,00m².

10. HALL, Edward T. A Dimensão Oculta, Lisboa ,Relógio D’Agua Editores,1966

A questão das diversas formas de abordagem da percepção dimensional, em função da cultura em que o espaço está inserido, é parte importante nesta publicação, fornecendo dados para o estudo do espaço sensorial.

11. Caixa Econômica Federal - Manual Técnico de Engenharia, São Paulo, CEFGIDUR/SP, 2002.

Publicação da Caixa Econômica Federal que, como agente financiador de recursos para empreendimentos imobiliários, apresenta na forma de caderno orientação de empreendimentos do setor privado, com objetivos de propor para a concepção de projetos aspectos relevantes e parâmetros técnicos 
para o dimensionamento habitacional, produzido com os seus recursos para financiamento.

Este trabalho visa estabelecer quantidades e dimensões mínimas para mobiliários e para a circulação entre eles, levando a determinar medidas mínimas para os ambientes, pré-estabelecidos, de uma habitação. Indica também exigências de desempenho da habitação para o usuário.

12. PANERO, Julius; Zelnik, Martin - Dimensionamento Humano para Espaços Interiores, Barcelona, Gustavo Gili, 2002.

Trata-se do primeiro e mais completo livro de referência, baseado na antropometria para padrões de projeto arquitetônico, editado inicialmente em 1979, onde os arquitetos Panero e Zelnik elaboraram, a partir de uma linha de pesquisa que vinha desde a década de 50, para o estudo dos espaços interiores. O livro divide-se em três partes, conceituando e apresentando elementos teóricos, de limitações e aplicações da ergonomia e antropometria; definindo dados antropométricos sob a forma de tabelas e ilustrações; e por fim, aplicando em uma série de padrões referenciais básicos de projeto, para os espaços interiores, sob a forma de plantas e cortes típicos, mostrando a relação adequada entre o usuário e o espaço. Assim, o dimensionamento dos ambientes é obtido a partir do estudo das relações das dimensões humanas com os espaços da edificação, sendo, portanto, os autores deste trabalho considerados responsáveis por uma visão moderna da antropometria, em que as medidas humanas devem ser consideradas nos projetos de arquitetura.

\section{RYBCZYNSKI, Witold, Casa Pequena História de Uma Idéia (Home- A} short_History of na Idea), 1986 Editora Record $3^{\mathrm{a}}$ edição.

"Definições unidimensionais e técnicas do conforto, que ignoram a história sempre serão insatisfatórias". Como são ricas, por comparação, as definições de conforto de Baldwin e de Alexander. Eles incluem a conveniência (uma mesa a mão), a eficiência (uma fonte de luz ajustável), a domesticidade (uma xícara de chá), o bem estar físico (cadeiras estofadas e almofadas) e a privacidade ( ler um livro, conversar)."pág. 235 
A definição e o início da domesticidade citada na vida dos moradores dos paises baixos é uma grande contribuição para o entendimento da evolução dos espaços domésticos até os dias atuais.

14. SCRUTON, Roger - Estética da Arquitetura (The Aesthetics of Architecture), 1979.- Livraria Martins Fontes, São Paulo.

"A solução para um problema de projeto só será satisfatória se apresentar, aos que vivem e trabalham com o produto, uma base adequada a compreensão prática deles próprios." (pág.37,SCRUTON, 1979), ou seja faz parte do trabalho do arquiteto

15. NEUFERT, Ernst - Industrializacion de las construciones : manual de la construccion racional con medidas normalizadas, Barcelona : Gili, 1965, pag. 35 apud POSSEBON, Enio.

[...] é importante que um arquiteto de tanta popularidade como Le Corbusier tenha dedicado sua atenção ao problema das medidas na construção e que tenha colocado em primeiro plano necessidades arquitetônicas que haviam sido deixadas de lado, como pouco acertadas,substituídas por normatizadores mecânicos e exclusivistas.

Não menos importante é o fato de que para desenvolver as construções se possa jogar com proporções baseadas na secção áurea"

\section{Bibliografia Consultada}

\section{Livros, Publicações e Pesquisas}

1. ARGAN, Giulio Carlo - Projeto e Destino, Editora Ática,2001.

2. FERREIRA, Aurélio Buarque de $\mathrm{H}$. Século XXI O Dicionário da Línqua Portuguesa, 1999, Editora Nova Fronteira Rio de Janeiro.

3. AYMONINO, La Vivienda Racional, Ponencias de los Congressos CIAM 1929-1930.- Gustavo Gilli , 1973. 
4. BRAGA, Maria Ângela - Qualidade da Habitação e Qualidade do Projeto: Método de Avaliação- São Paulo, Tese de Doutorado - Faculdade de Arquitetura e Urbanismo da Universidade de São Paulo, 1998

5. BOUERI, Jorge - Antropometria Fator de Dimensionamento da Habitação, São Paulo, FAU USP, 1989. Tese de doutorado CPG FAU USP.

6. BOUERI, Jorge - Antropometria Aplicada à Arquitetura, Urbanismo e Desenho Industrial, Manual de Estudo, Volume I - São Paulo, FAU USP, $3^{a}$ edição,1999.

7. - Espaço de Atividades, Apostila, FAU USP. São Paulo, 2004.

8. - Espaço Mínimo da Habitação, Apostila, FAU USP. São Paulo, 1997.

9. - A Contribuição da Ergonomia na Formação do Arquiteto Tese de Livre Docência - São Paulo, FAU USP, 2004

10. BRAGA, Maria Ângela - Qualidade no Projeto e Qualidade na Habitação: Método de Avaliação- 1998 -FAU USP CPG, Tese de Doutorado.

11. FONSECA, Nuno de Azevedo - A Arquitetura do Mercado Imobiliário e seu Processo de Produção na cidade de São Paulo, FAU USP CPG, Tese de Doutorado.

12. GRADJEAN, Etienne - Ergonomic of the Home, Taylor \& Francis, London, 1972

13. HANNAH Arendt, A Condição Humana, editora da USP, 1981.

14. HEIDEGGER, Martin, Ser e Tempo, editora Vozes, Petrópolis 1997.

15. HOMEM, Maria Cecília N. - O Palacete Paulistano e outras Formas Urbanas de Morar da Elite Cafeeira 1867-1918, Ed. Martins Fontes, 1996.

16. INKLES, Gordon and SCHENCKE, Iris - Ergonomic Living, Simon \& Schuster Inc., New York.

17. Kenchian, Alexandre, Estudos de Modelos e Técnicas para Projeto e Dimensionamento dos Espaços da Habitação, dissertação de mestrado FAU USP, 2005.

18. LE CORBUSIER - El Modulor - ensayo sobre una medida armonica a la escala humana aplicable universalmente a la arquitectura y la mecanica. Buenos Aires, Editorial Poseidon, 1961. 
19. - Modulor 2 - 1955 (los usuarios tienen la palabra) continuación de "El Modulor - 1948" Buenos Aires, Editorial Poseidon, 1962.

20. LEMOS, Carlos A. C. - Cozinha, etc. São Paulo, Perspectiva, 1978. Alvenaria burguesa - quando surgiram os apartamento em São Paulo.

21. . - Casa Paulista, Edusp,1999.

22. - Arquitetura Brasileira, Edições Melhoramentos Edusp, 1979.

23. e CORONA, Eduardo - Roteiro da Arquitetura Contemporânea em São Paulo, Separata da Revista Acrópole, 295/296.

24. LEMOS, Carlos XAVIER, Alberto CORONA, Eduardo- Arquitetura Moderna Paulista, Editora Pini São Paulo, 1983

25. LEVI, Rino - Editora Comunitá , Milão, 1974.

26. KLEIN, Alexandre - La Vivenda Mínima:1906-1957, Barcelona, G.Gili, 1980.

27. MARCUS, Claire Cooper - House as a Mirror of Self:exploring the Deeper Meaning of Home", Berkeley, California, onari Press- 1995.

28. MARK, Davis Major; Tuim, Storno; Alan Penn; Bill Hillier- publicado em 1997Conferencia Internacional Making Cities Livable,- Children and Youth in the City Proceedings - Charleston, SC USA.

29. MARICATO, Erminia - Metrópole na Periferia do Capitalismo Legalidade, Desigualdade e Violência, Husitec - São Paulo, 1996.

30. MEYER, João Fernando Pires - Adoção de métodos de análise de mercado imobiliário nas decisões de projeto - Rio de Janeiro, Trabalho de Evento, 2000.

31. MORAES, A. \& MONT'ALVÃO, C. - Ergonomia: conceitos e aplicações Rio de Janeiro, 1998.

32.MUNFORD, Lewis - A cidade na história, suas origens, transformações e perspectivas. São Paulo, Martins Fontes,1982.

33. MICHELSON, W. - "Environmental choice, human behavior and residential satisfaction" - Toronto, 1977

34. OLIVEIRA, Maria Carolina G; FREITAS, Ana Augusta F e HINECK, Luiz Fernando M. - Explicação da formação de Preferências Habitacionais Utilizando o Conceito de Ciclo de Vida, pesquisa, Florianópolis.

35.PECHMAN, Robert M. e RIBEIRO, Luiz C. de Queirós, - O que é a Questão da Moradia, Editora Nova cultural/Brasiliense, UFSC-Florianópolis, 1985. 
36. PANERO, J. \& Zelnik, Martin. Human Dimension and Interior Space. London, The Architectural Press, Ltd. 1979.

37. PEDRO, João Branco - Programa Habitacional - ITA 6 - Lisboa, Laboratório Nacional de Engenharia Civil (LNEC), 1999.

38. PORTAS, Nuno - Definição e Evolução das Normas da Habitação.Si, Sn. 1966

39. RYKWERT, Joseph A Casa de Adão no Paraíso :a idéia da cabana primitiva na história da Arquitetura, São Paulo Editora Perpectiva 2003.

40. SAMPAIO, Maria Ruth Amaral - Promoção Privada de Habitação Econômica e a Arquitetura Moderna 1930-1964, São Carlos, Rima Editora, 2002

41. SCHWARZ, Roberto - Um Mestre na Periferia do Capitalismo, Editora 2 Cidades,1990, capítulo V - Conformação Social do Brasileiro.

42. UNITED NATIONS, Department of Economic and Social Affairs -Methods of Estimating Housing Needs, New York, 1967.

43.SCHOENAUER, Norbert $-\underline{6,000}$ Years of Housing, w.w. Norton and Company - New York-London -1981.

44. TRAMONTANO, Marcelo - "Novos Modos de Vida, Novos Espaços de Morar, uma Reflexão sobre a Habitação Contemporânea, São Paulo, Paris, Tóquio"- São Paulo - 1998- Tese Doutorado - FAU -USP.

\section{Normas Técnicas e Manuais}

1. Memorial Técnico de Engenharia Caixa Econômica Federal.

2. NBR 9050/1994 - Acessibilidade de Pessoas Portadoras de Deficiências a Edificações, Espaço, Mobiliário e Equipamentos Urbanos - Rio de Janeiro, ABNT, 1994

3. Comissão Permanente de Acessibilidade (CPA) - Guia de Acessibilidade em Edificações - São Paulo, Secretaria da Habitação e Desenvolvimento Urbano da Prefeitura do Município de São Paulo (SEHAB), 2002

4. Guia para Mobilidade Acessível em Vias Públicas - São Paulo, Secretaria da Habitação e Desenvolvimento Urbano da Prefeitura do Município de São Paulo (SEHAB), 2003

5. Corpo de Bombeiros da Polícia Militar do Estado de São Paulo - Regulamento de Segurança Contra Incêndio - Decreto Estadual 46.076/2001 e Instruções Técnicas - São Paulo, Governo do Estado de São Paulo, 2001 
6. Código de Obras e Edificações, Prefeitura do Município de São Paulo: Lei $n^{\circ}$ 11.228/92, e Decreto no 32.329/92 - São Paulo, Imprensa Oficial do Estado IMESP, 1992.

\section{Fontes Informais}

$5^{\circ}$ Congresso Internacional de Ergonomia e Usabilidade de Interfaces, 31/05/2005 PUC/ Rio - Rio de Janeiro .

BOUERi, J.J. e Mendonça, Marcelo

Índices Ergonômicos uma Proposta de Avaliação Dimensional da Habitação

\section{Revistas e Periódicos}

Guia do Imóvel, periódico mensal comercial - editora Abril, 2002,2003,2004.

Jornal O Estado de São Paulo

Folhetos de distribuição gratuita de Empreendedores

\section{Sites Visitados:}

1- COELHO, Antonio Baptista.- Habitar com Qualidade e Urbanidade - site do grupo habitar

http://www-ext.Inec.pt/GH-APPOH/Site/htm/textos.htm em 16/01/2007

2- Publicada originalmente em PROJETO DESIGN Edição 275 Janeiro 2003. http://www.arcoweb.com.br/arquitetura/arquitetura344.asp

3- http://www.gafisa.com.br/orsini/home.asp- 11/04/2005

4- Texto Especial 286 - Dize-me teu nome, tua altura e onde moras e te direi quem és: estratégias de marketing e a criação da casa ideal - parte 2 (1)- março 2005 de LOUREIRO, Claudia e AMORIM ,Luiz - professores da Universidade de Federal Pernambuco, Brasil.http://www.vitruvius.com.br-

5- Imagens Ilustrativas de Welwyn Garden City.

http://www.rickmansworthherts.freeserve.co.uk/howard2.htm- 
6- Apartamento Paulistano a passagem do século, consulta em 07/02/2006. http://www.eesc.usp.br/nomads/pesquisa.htm\#

7- "O Herói e o Fora da Lei", artigo de MARINHO, Luiz Alberto, sobre o livro " The Hero and the Outlaw: Building Extraordinary Brands through the Power of Archetypes"de Margaret Mark, Carol S. Pearson January 2001, The McGraw-Hill Companies,

http://www.bluebus.com.br/show.php?p=1\&id=38983consulta em 31/03/2006.

8 -Imagen Ilustrativa da casa de Oak Park, Frank Lloyd Wright, Chicago 1889. http://www.cbe.org.uk/ Chicago\%20visit/Photographs\%20...(foto)6

9 - Imagem Ilustrativa da Muralha de Drubrovinik http://www.croatia.net/html/gallery6.html

10-Desenho ilustrativo da Place Royale. maio 2006.

http://marais.evous.fr/marais/patrimoine/place-des-vosges/place-des-vosges.htm

11- Imagem Ilustrativa Place Royale.maio/2005

http://www.bluffton.edu/ sullivanm/vosges/vosges.html

12-Imagem Ilustrativa Convent Garden 05/05/2006

http://intranet.arc.miami.edu/riohn/Spring2000/New\%20slides/Jones\%20and\%20 Wren\%20slides/Convent\%20Garden.jpg

13- -Imagem Ilustrativa de Quen's Square east side 05/2006.

http://www.bathmuseum.co.uk/buildings.htm

14 - Imagem llustrativa King's Cecos 05/2006

http://www.bathmuseum.co.uk/images/gallery/Roofline\%20of\%20King\%27s\%20

Circus.jpg $/$.

15- Imagem empreendimento T2 e T3 Eco Vitta_29/08/2006.

http://planeta.terra.com.br/educacao/supertomcat/f14tomcat/cabine/fotopf14d2. http://www.ecovittasabara.com.br/ -

16- Imagens T2 e T3 Nova Mooca 12/12/2006

http://www.cyrela.com.br/Web/ficha/novamooca/ 


\section{ANEXOS}

1. Composição de Mobiliário Equipamentos e Componentes

2. Levantamento de Ambientes- Inventário FAPESP

3. Folhas -Manual Técnico da CEF.

4. Tabela dos Ambientes mais encontrados - Trabalho programado autor

5. Conjunto de Função e Uso.

6. Plantas Utilizadas para a Aplicação do Método.

7. Desenhos Utilizados - Espaços de Atividade

8. Tabelas de Síntese Global, do Valor de Desempenho

9. Trabalho de Aplicação do Método de Alexandre Klein.

10. Tabela do Jornal o estado de São Paulo. 


\section{Análise da Composição do Mobiliário e Equipamento | Ambiente Dormitórios \\ Fonte: Mercado Imobiliário SP}

\begin{tabular}{|c|c|c|c|c|c|c|c|c|c|c|}
\hline \multirow[t]{2}{*}{ Ambientes } & \multicolumn{8}{|c|}{ Tipologia de Projeto } & \multirow[b]{2}{*}{$\begin{array}{l}\overrightarrow{\widetilde{z}} \\
\underset{\sim}{0}\end{array}$} & \multirow[b]{2}{*}{ do } \\
\hline & 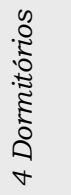 & do & 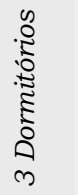 & do & 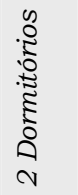 & do & 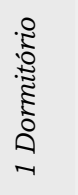 & do & & \\
\hline Dormitórios & 242 & & 255 & & 110 & & 17 & & 624 & \\
\hline Guarda - Roupa & 229 & 94.6 & 240 & 94.1 & 110 & 100.0 & 17 & 100.0 & 596 & 95.5 \\
\hline Criado - Mudo & 189 & 78.1 & 180 & 70.6 & 84 & 76.4 & 15 & 88.2 & 456 & 73.1 \\
\hline Cadeira & 184 & 76.0 & 131 & 51.4 & 48 & 43.6 & 16 & 94.1 & 372 & 59.6 \\
\hline Cama de Solteiro & 150 & 62.0 & 154 & 60.4 & 55 & 50.0 & 1 & 5.9 & 360 & 57.7 \\
\hline Bancada | Mesa de Trabalho & 109 & 45 & 137 & 53.7 & 44 & 40 & 13 & 76.4 & 298 & 47.8 \\
\hline Cama de Casal & 67 & 27.7 & 85 & 33.3 & 55 & 50.0 & 12 & 70.6 & 219 & 35.1 \\
\hline Estante de TV | Rack & 112 & 46.3 & 50 & 19.6 & 28 & 25.5 & 8 & 47.1 & 193 & 30.9 \\
\hline Mesa Lateral & 13 & 5.4 & 65 & 25.5 & 25 & 22.7 & 9 & 52.9 & 112 & 17.9 \\
\hline Sofá - Cama & 24 & 9.9 & 16 & 6.3 & & & & & 40 & 6.4 \\
\hline Cômoda & 18 & 7.4 & 5 & 2.0 & 3 & 2.7 & & & 26 & 4.2 \\
\hline Luminária de Pé & 19 & 7.9 & 6 & 2.4 & & & & & 25 & 4.0 \\
\hline Puff & 6 & 2.5 & 14 & 5.5 & 2 & 1.8 & & & 22 & 3.5 \\
\hline Roupeiro & 16 & 6.6 & 1 & 0.4 & 2 & 1.8 & 1 & 5.9 & 21 & 3.4 \\
\hline Poltrona & 7 & 2.9 & 6 & 2.4 & 1 & 0.9 & 3 & 17.6 & 14 & 2.2 \\
\hline Mesa de Centro & 6 & 2.5 & & & & & 2 & 11.8 & 8 & 1.3 \\
\hline Baú & 4 & 1.7 & 2 & 0.8 & & & 1 & 5.9 & 7 & 1.1 \\
\hline Mesa de 2 Lugares & 4 & 1.7 & & & & & 1 & 5.9 & 5 & 0.8 \\
\hline Sofá de 2 Lugares & & & & & & & 4 & 23.5 & 4 & 0.6 \\
\hline Sapateira & & & 1 & 0.4 & 3 & 2.7 & & & 4 & 0.6 \\
\hline Pia & & & & & & & 3 & 17.6 & 3 & 0.5 \\
\hline Mesa & 2 & 0.8 & & & & & 1 & 5.9 & 3 & 0.5 \\
\hline Sofá de 5 Lugares & 1 & 0.4 & & & & & & & 1 & 0.2 \\
\hline Geladeira & & & & & & & 3 & 17.6 & 3 & 0.5 \\
\hline Fogão & & & & & & & 3 & 17.6 & 3 & 0.5 \\
\hline Banco & & & & & & & 3 & 17.6 & 3 & 0.5 \\
\hline Microondas & & & & & & & 1 & 5.9 & 1 & 0.2 \\
\hline Mesa de 3 Lugares & & & & & & & 1 & 5.9 & 1 & 0.2 \\
\hline Telefone & 99 & 40.9 & 4 & 1.6 & 1 & 0.9 & 2 & 11.8 & 106 & 17.0 \\
\hline Computador & 69 & 28.5 & 52 & 20.4 & 13 & 11.8 & 5 & 29.4 & 139 & 22.3 \\
\hline TV & 112 & 46.3 & 68 & 26.7 & 27 & 24.5 & 10 & 58.8 & 214 & 34.3 \\
\hline Abajur & 242 & 100.0 & 255 & 100.0 & 102 & 92.7 & 16 & 94.1 & 615 & 98.6 \\
\hline
\end{tabular}




\section{Composição de Mobiliário | Equipamentos Cozinha \\ Fonte: Pesquisa Mercado Imobiliário SP}

\section{Ambiente}

\begin{tabular}{|c|c|c|c|c|c|c|c|c|c|c|}
\hline & 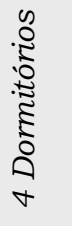 & do & 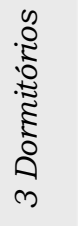 & do & 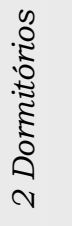 & de & 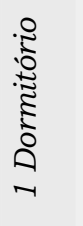 & de & 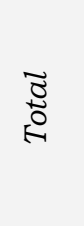 & do \\
\hline Amostra & 62 & 28,3 & 85 & 38,8 & 55 & 25,1 & 17 & 7,8 & 219 & 100 \\
\hline Copa | Cozinha & 26 & & 51 & & 35 & & 12 & & 124 & \\
\hline Pia de 1 e 2 Cubas & 26 & 100.0 & 51 & 100.0 & 35 & 100.0 & 12 & 100.0 & 124 & 100.0 \\
\hline Geladeira & 26 & 100.0 & 51 & 100.0 & 35 & 100.0 & 12 & 100.0 & 124 & 100.0 \\
\hline Fogão & 26 & 100.0 & 51 & 100.0 & 35 & 100.0 & 12 & 100.0 & 124 & 100.0 \\
\hline Cadeira & 26 & 100.0 & 51 & 100.0 & 19 & 54.3 & 12 & 100.0 & 108 & 87.1 \\
\hline Pia de 1 Cuba & 12 & 46.2 & 34 & 66.7 & 35 & 100.0 & 12 & 100.0 & 93 & 75.0 \\
\hline Armário & 12 & 46.2 & 30 & 58.8 & 4 & 11.4 & 12 & 100.0 & 58 & 46.8 \\
\hline Freezer & 17 & 65.4 & 36 & 70.6 & 4 & 11.4 & & & 57 & 46.0 \\
\hline Mesa de $2 \mathrm{P}$ & 5 & 19.2 & 25 & 49.0 & 11 & 31.4 & 9 & 75.0 & 50 & 40.3 \\
\hline Máquina de Lavar Louça & 10 & 38.5 & 28 & 54.9 & 11 & 31.4 & & & 49 & 39.5 \\
\hline Banco & 4 & 15.4 & 36 & 70.6 & 7 & 20.0 & & & 47 & 37.9 \\
\hline Mesa de $4 \mathrm{P}$ & 23 & 88.5 & 14 & 27.5 & 5 & 14.3 & 3 & 25.0 & 45 & 36.3 \\
\hline Pia de 2 Cubas & 14 & 53.8 & 17 & 33.3 & & & & & 31 & 25.0 \\
\hline Microondas & 10 & 38.5 & 9 & 17.6 & 3 & 8.6 & & & 22 & 17.7 \\
\hline Mesa de $3 \mathrm{P}$ & 5 & 19.2 & 11 & 21.6 & 3 & 8.6 & & & 19 & 15.3 \\
\hline Bancada & 12 & 46.2 & 1 & 2.0 & & & & & 13 & 10.5 \\
\hline Telefone & 4 & 15.4 & & & & & & & 4 & 3.2 \\
\hline TV & 3 & 11.5 & & & & & & & 3 & 2.4 \\
\hline Estante de TV & 2 & 7.7 & & & & & & & 2 & 1.6 \\
\hline Sofá de 4 Lugares & 1 & 3.8 & & & & & & & 1 & 0.8 \\
\hline Mesa de $6 \mathrm{P}$ & 1 & 3.8 & & & & & & & 1 & 0.8 \\
\hline Despensa de Cozinha & 24 & & 4 & & & & & & 28 & \\
\hline Armário & 24 & 100.0 & 100 & & & & & & 28 & 100.0 \\
\hline Closet de Utensílios & 3 & & & & & & & & 3 & \\
\hline Armário & 3 & 100.0 & & & & & & & 3 & 100.0 \\
\hline Adega & 1 & & & & & & & & 1 & \\
\hline Armário & 1 & 100.0 & & & & & & & 1 & 100.0 \\
\hline
\end{tabular}


Composição de Mobiliário, Equipamentos e Componentes.

Banheiros

Fonte: Pesquisa Mercado Imobiliário SP

\begin{tabular}{|c|c|c|c|c|c|c|c|c|c|c|}
\hline \multirow[t]{2}{*}{ Ambiente } & \multicolumn{8}{|c|}{ Tipologia de Projeto } & \multirow[b]{2}{*}{$\underset{\underset{\sim}{0}}{\widetilde{\Xi}}$} & \multirow[b]{2}{*}{ de } \\
\hline & 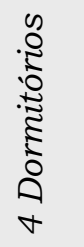 & de & 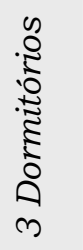 & de & 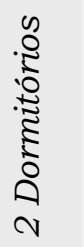 & de & 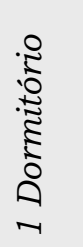 & de & & \\
\hline Amostra & 62 & 28,3 & 85 & 38,8 & 55 & 25,1 & 17 & 7,8 & 219 & 100 \\
\hline Banheiro Dormitório Casal & 60 & 96,7 & 73 & 85,9 & 33 & 60,0 & 6 & 35,3 & 172 & 100.0 \\
\hline Vaso Sanitário & 60 & 100.0 & 73 & 100.0 & 33 & 100.0 & 6 & 100.0 & 172 & 100.0 \\
\hline Lavatório Cuba Simples & 36 & 60.0 & 71 & 97.3 & 33 & 100.0 & 5 & 83.3 & 145 & 84.3 \\
\hline Box c Chuveiro & 34 & 56.7 & 64 & 87.7 & 32 & 97.0 & 6 & 100.0 & 136 & 79.1 \\
\hline Bidê & 41 & 68.3 & 10 & 13.7 & 2 & 6.1 & 1 & 16.7 & 54 & 31.4 \\
\hline Banheira c Chuveiro & 28 & 46.7 & 8 & 11.0 & 1 & 3.0 & & & 37 & 21.5 \\
\hline Lavatório Cuba Dupla & 24 & 40.0 & 2 & 2.7 & & & 1 & 20.0 & 27 & 18.6 \\
\hline Banheira & 14 & 23.3 & & & & & 1 & 16.7 & 15 & 8.7 \\
\hline Banheiro Dormitório & 51 & 82,2 & 7 & 8,2 & 3 & 5,4 & & & 61 & 100.0 \\
\hline Lavatório Cuba Simples & 51 & 100.0 & 7 & 100.0 & 3 & 100.0 & & & 61 & 100.0 \\
\hline Vaso Sanitário & 51 & 100.0 & 7 & 100.0 & 3 & 100.0 & & & 61 & 100.0 \\
\hline Box c Chuveiro & 51 & 100.0 & 7 & 100.0 & 3 & 100.0 & & & 61 & 100.0 \\
\hline Bidê & 9 & 17.6 & & & & & & & 9 & 17.6 \\
\hline Banheiro Social & 49 & 79,0 & 78 & 91,7 & 52 & 94,5 & 11 & 64,7 & 190 & 100.0 \\
\hline Lavatório Cuba Simples & 49 & 100.0 & 78 & 100.0 & 52 & 100.0 & 11 & 100.0 & 190 & 100.0 \\
\hline Vaso Sanitário & 49 & 100.0 & 78 & 100.0 & 52 & 100.0 & 11 & 100.0 & 190 & 100.0 \\
\hline Box c Chuveiro & 49 & 100.0 & 78 & 100.0 & 52 & 100.0 & 8 & 72.7 & 187 & 100.0 \\
\hline Bidê & 3 & 6.1 & & & & & 1 & 9.1 & 4 & 2.1 \\
\hline Banheira c Chuveiro & & & & & & & 3 & 27.3 & 3 & 1.6 \\
\hline Lavabo & 54 & 87,1 & 25 & 29,4 & 3 & 5,4 & 1 & 5,9 & 83 & 100.0 \\
\hline Lavatório Cuba Simples & 54 & 100.0 & 25 & 100.0 & 3 & 100.0 & 1 & 100.0 & 83 & 100.0 \\
\hline Vaso Sanitário & 54 & 100.0 & 25 & 100.0 & 3 & 100.0 & 1 & 100.0 & 83 & 100.0 \\
\hline Banheiro de Serviço & 58 & 93,5 & 55 & 64,7 & 9 & 16,3 & & & 122 & 55,7 \\
\hline Lavatório Cuba Simples & & & & & & & & & & \\
\hline Vaso Sanitário & & & & & & & & & & \\
\hline Chuveiro & & & & & & & & & & \\
\hline
\end{tabular}


Composição de Mobiliário, Equipamentos e Componentes.

Salas

Fonte: Pesquisa Mercado Imobiliário SP

Ambiente

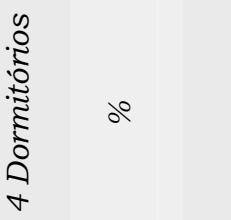

Amostra

$62 \quad 28,3$
Tipologia de Projeto

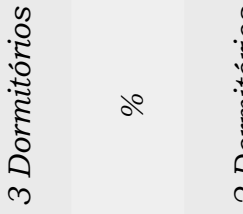

de

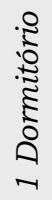

$\underset{\substack{\tilde{\sigma} \\ \sim}}{\mathbb{Z}}$

de

100

\section{Escritório Biblioteca}

Cadeira

Bancada (medida variável)

Mesa de Trabalho

85

38,8

55

25,1

17

7,8

219

Mesa Lateral

Poltrona

Sofá de 2 Lugares

Estante de TV

Armário

Computador

Telefone

Luminária de Pé

TV

$\begin{array}{rrrrr} & 4 & & 1 & \\ 100.0 & 4 & 100.0 & 1 & 100.0 \\ 66.7 & 4 & 100.0 & 1 & 100.0 \\ 83.3 & & & & \\ 50.0 & & & & \\ 33.3 & & & & \\ 16.7 & 1 & 25.0 & & \\ 16.7 & & & & \\ & 1 & 25.0 & & \\ 66.7 & 4 & 100.0 & & \\ 66.7 & & & & 1 \\ 16.7 & & & 1 & 100.0 \\ & & & 1 & 100.0\end{array}$

100.0

81.8

45.5

27.3

18.2

18.2

9.1

9.1

72.7

36.4

18.2

9.1

\section{Terraço Social}

Cadeira

Mesa Lateral

Churrasqueira

Mesa de 4 Lugares

Espreguiçadeira

Mesa de 2 Lugares

Mesa de Centro

Poltrona

Mesa de 3 Lugares

Banco de 2 Lugares

Aparador

Banco

Sofá de 2 Lugares

Mesa de 6 Lugares

Bancada

$\begin{array}{rr}62 & \\ 60 & 96.8 \\ 41 & 66.1 \\ 47 & 75.8 \\ 30 & 48.4 \\ 26 & 41.9 \\ 4 & 6.5 \\ 12 & 19.4 \\ 3 & 4.8 \\ 5 & 8.1 \\ 8 & 12.9 \\ 4 & 6.5 \\ & \\ 1 & 1.6 \\ 1 & 1.6 \\ 1 & 1.6\end{array}$

84
60
45

$\begin{array}{rrrrrr}71.4 & 48 & & 7 & & 201 \\ 53.6 & 27 & 56.3 & 4 & 57.1 & 117 \\ 2.4 & & & & \\ 10.7 & 2 & 4.2 & & \\ 8.3 & & & 2 & 28.6 \\ 20.2 & & & & \\ 6.0 & 4 & 8.3 & & \\ 10.7 & 7 & 14.6 & 1 & 14.3 \\ 1.2 & 3 & 6.3 & & \\ 0.0 & & & & \\ 0.0 & & 0.0 & & \\ 0.0 & 2 & 4.2 & & \\ 0.0 & & 0.0 & & \\ 0.0 & & 0.0 & & \end{array}$


Composição de Mobiliário, Equipamentos e Componentes.

\section{Salas}

Fonte: Pesquisa Mercado Imobiliário SP

\section{Ambiente}

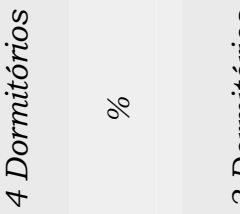

\section{Amostra}

\section{Salas}

Cadeira

Mesa Lateral

Poltrona

Mesa de Centro

Sofá de 3 Lugares

Aparador

Estante de TV

Mesa de Jantar de $6 \mathrm{P}$

Sofá de 2 Lugares

Banco

Mesa de Jantar de $4 \mathrm{P}$

Mesa de Jantar de $8 \mathrm{P}$

Bancada

Churrasqueira

Puff

Espreguiçadeira

Luminária de Pé

Mesa de Jantar de $2 \mathrm{P}$

Bar

Armário

Sofá de 4 Lugares

Mesa de Jantar $3 \mathrm{P}$

Mesa de Jantar de 5 P

Mesa de Trabalho

Pia

Microondas

Mesa de Jantar de 10 P

Piano

Sofá de 5 Lugares

Mesa de Jantar de 12 P

Sofá de 6 Lugares

Tanque

Abajur

TV

Telefone

Computador

Fogão

Geladeira

Máquina de Lavar Roupa

6228,3

14987.

$\begin{array}{ll}37 & 80.1 \\ 52 & 30.4\end{array}$

28.7

6.4

27.5

9.4

15.8

9.4

4.7

5.3

3.5

6.4

2.9

$\begin{array}{ll}8 & 4.7\end{array}$

21.2

$\begin{array}{ll}2 & 1.2 \\ 3 & 1.8\end{array}$

21.2

21.2

$\begin{array}{ll}171 & 100.0\end{array}$

$40 \quad 23.4$

4.7

\section{Tipologia de Projeto}
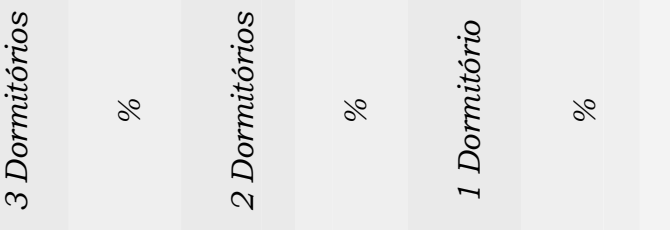

$\underset{\sim}{\tilde{\sigma}}$

do

8538

55
107
102

25,1

17

7,8

219

100

$\begin{array}{lll}176 & & 107 \\ 151 & 85.8 & 102\end{array}$

$130 \quad 73.9$

$81 \quad 75.7$

$\begin{array}{ll}72 & 67.3\end{array}$

$53 \quad 49.5$

$\begin{array}{ll}58 & 49.5 \\ 4 & 49.9\end{array}$

$49 \quad 45.8$

$49 \quad 45.8$

$34 \quad 31.8$

$\begin{array}{ll}34 & 31.8 \\ 19 & 13.1\end{array}$

$19 \quad 17.8$

$\begin{array}{ll}19 & 17.8\end{array}$

$15 \quad 14.0$

33
18

18

\section{5}

54.5
45.5

45.5

21.2

27.3

42.4

18.2

39.4

33.3

18.2

$7 \quad 6.5$

0.0

$10 \quad 9.3$

4.5

10.8

9.1

2.8

2.3

0.6

1.7

0.6

0.6

0.6

0.6

0.6

$\begin{array}{ll}39 & 22.8\end{array}$ 


\section{Composição de Mobiliário Equipamento e Componentes. Área de Serviço Fonte: Pesquisa Mercado Imobiliário SP}

\begin{tabular}{|c|c|c|c|c|c|c|c|c|c|c|}
\hline \multirow[t]{2}{*}{ Ambiente } & \multicolumn{8}{|c|}{ Tipologia de Projeto } & \multirow[b]{2}{*}{ 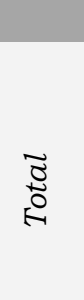 } & \multirow[b]{2}{*}{ de } \\
\hline & 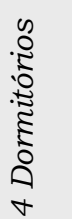 & de & 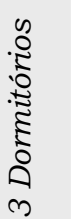 & de & 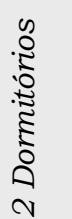 & de & 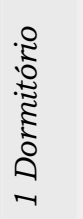 & de & & \\
\hline Amostra & 62 & 28,3 & 85 & 38,8 & 55 & 25,1 & 17 & 7,8 & 219 & 100 \\
\hline Área de Serviço & 62 & 100.0 & 85 & 100.0 & 55 & 100.0 & 6 & 35.3 & 202 & 92.2 \\
\hline MLR & 62 & 100.0 & 85 & 100.0 & 55 & 100.0 & 6 & 100.0 & 202 & 100.0 \\
\hline Tanque 1 Cuba & 53 & 85.5 & 85 & 100.0 & 55 & 100.0 & 6 & 35.3 & 193 & 95.5 \\
\hline Armário & 45 & 72.6 & 32 & 37.6 & 21 & 38.2 & 3 & 50.0 & 98 & 48.5 \\
\hline Máquina de Secar Roupa & 55 & 88.7 & 33 & 38.8 & 3 & 5.5 & & & 91 & 45.0 \\
\hline Bancada & 34 & 54.8 & 33 & 38.8 & & & 4 & 23.5 & 67 & 33.2 \\
\hline Aquecedor de Acumulação & 24 & 38.7 & 7 & 8.2 & & & & & 31 & 15.3 \\
\hline Aquecedor de Passagem & 9 & 14.5 & 2 & 2.4 & 2 & 3.6 & & & 13 & 6.4 \\
\hline Tanque 2 Cubas & 9 & 14.5 & & & & & & & 9 & 4.5 \\
\hline Cadeira & 2 & 3.2 & & & & & & & 2 & 1.0 \\
\hline Mesa de 2 Lugares & 1 & 1.6 & & & & & & & 1 & 0.5 \\
\hline $\begin{array}{l}\text { TV } \\
\text { Tabua de Passar Roupa }\end{array}$ & 1 & 1.6 & & & & & & & 1 & 0.5 \\
\hline Depósito de Serviço & 62 & 100.0 & 1 & 1.2 & & & & & 63 & 28.8 \\
\hline Armário & & & 1 & 100.0 & & & & & 1 & 1.6 \\
\hline 10. Dormitório de Serviço & 58 & 93.5 & 33 & 38.8 & 2 & 3.6 & & & 93 & 42.5 \\
\hline Cama & 53 & 91.4 & 29 & 87.9 & 2 & 100.0 & & & 84 & 90.3 \\
\hline Guarda - Roupa & 41 & 70.7 & 25 & 75.8 & 1 & 50.0 & & & 67 & 72.0 \\
\hline Abajur & 9 & 15.5 & 6 & 18.2 & & & & & 15 & 16.1 \\
\hline Criado-mudo & 1 & 1.7 & 8 & 24.2 & & & & & 9 & 9.7 \\
\hline Sofá - Cama & 2 & 3.4 & 4 & 12.1 & & & & & 6 & 6.5 \\
\hline TV & 3 & 5.2 & 2 & 6.1 & & & & & 5 & 5.4 \\
\hline Estante de TV & 2 & 3.4 & & & & & & & 2 & 2.2 \\
\hline Cômoda & 1 & 1.7 & & & & & & & 1 & 1.1 \\
\hline Mesa de Trabalho & 1 & 1.7 & & & & & & & 1 & 1.1 \\
\hline $2^{2}$. Dormitório de Serviço & 7 & 11.3 & & & & & & & 7 & 3.2 \\
\hline Cama & 7 & 100.0 & & & & & & & 7 & 100.0 \\
\hline Guarda - Roupa & 7 & 100.0 & & & & & & & 7 & 100.0 \\
\hline TV & 2 & 28.6 & & & & & & & 2 & 28.6 \\
\hline Estante de TV & 1 & 14.3 & & & & & & & 1 & 14.3 \\
\hline Mesa de Trabalho & 1 & 14.3 & & & & & & & 1 & 14.3 \\
\hline Criado - Mudo & 1 & 14.3 & & & & & & & 1 & 14.3 \\
\hline Banheiro de Serviço & 58 & 93.5 & 55 & 64.7 & 9 & 16.4 & & & 122 & 55.7 \\
\hline Vaso Sanitário & 58 & 100.0 & 55 & 100.0 & 9 & 100.0 & & & 122 & 100.0 \\
\hline Chuveiro & 58 & 100.0 & 50 & 90.9 & 6 & 66.7 & & & 114 & 93.4 \\
\hline Lavatório Cuba Simples & 58 & 100.0 & 49 & 89.1 & 5 & 55.6 & & & 112 & 91.8 \\
\hline
\end{tabular}




\section{Composição de Ambiente Projetos}

\begin{tabular}{|c|c|c|c|c|c|c|c|c|c|c|}
\hline \multirow[t]{2}{*}{ Ambientes } & \multicolumn{8}{|c|}{ Tipologia de Projeto } & \multirow[b]{2}{*}{$\begin{array}{l}\text { I } \\
\stackrel{0}{\circ}\end{array}$} & \multirow[b]{2}{*}{ de } \\
\hline & 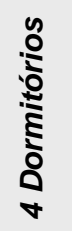 & de & 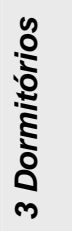 & do & 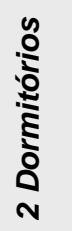 & de & 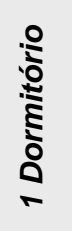 & do & & \\
\hline Amostra & 62 & 28,3 & 85 & 38,8 & 55 & 25,1 & 17 & 7,8 & 219 & 100 \\
\hline Dormitório Casal Principal & 62 & 100 & 85 & 100 & 55 & 100 & 12 & 70,6 & 214 & 97,7 \\
\hline Dormitório Casal Extra & 5 & 8,0 & & & & & & & & \\
\hline $1^{0}$. Dormitório Duplo & 57 & 91,9 & 82 & 96,4 & 49 & 89,0 & 2 & 11,7 & 190 & 86,7 \\
\hline $2^{0}$. Dormitório Duplo & 27 & 43,5 & 19 & 22,3 & & & & & 46 & 21,0 \\
\hline $3^{0}$. Dormitório Duplo & 3 & 4,8 & & & & & & & & \\
\hline $1^{0}$. Dormitório Simples & 49 & 79,0 & 50 & 58,8 & 6 & 10,9 & & & 105 & 47,9 \\
\hline $2^{0}$. Dormitório Simples & 14 & 22,5 & 3 & 3,5 & & & & & 17 & 7,7 \\
\hline $3^{0}$. Dormitório Simples & 1 & 1,6 & & & & & & & 1 & 0,4 \\
\hline Dormitório Reversível & 24 & 38,7 & 16 & 18,8 & & & & & 40 & 18,3 \\
\hline Closet do Dormitório & 51 & 82,2 & 25 & 29,4 & 4 & 7,3 & 2 & 11,7 & 82 & 37,4 \\
\hline Terraço do Dormitório & 48 & 77,4 & 11 & 12,9 & 4 & 7,3 & 7 & 41,2 & 70 & 31,9 \\
\hline Rouparia & 11 & 17,7 & 1 & 1,2 & & & 1 & 5,9 & 13 & 5,9 \\
\hline I Dormitório, Sala e Cozinha. & & & & & & & 3 & 17,6 & 3 & 1,3 \\
\hline
\end{tabular}

\section{Composição de Ambiente Projetos}

\section{Ambientes}

\begin{tabular}{|c|c|c|c|c|c|c|c|c|c|c|}
\hline \multirow[t]{2}{*}{ Ambientes } & \multicolumn{8}{|c|}{ Tipologia de Projeto } & \multirow[b]{2}{*}{$\begin{array}{l}\text { ত̃ } \\
\text { চ }\end{array}$} & \multirow[b]{2}{*}{ de } \\
\hline & 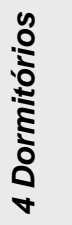 & de & 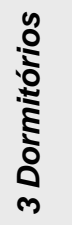 & de & 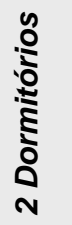 & de & 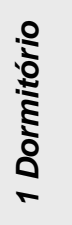 & de & & \\
\hline Amostra & 62 & 28,3 & 85 & 38,8 & 55 & 25,1 & 17 & 7,8 & 219 & 100 \\
\hline Sala de Estar & 16 & 25,8 & & & & & & & 16 & 7,3 \\
\hline Sala de Jantar & 14 & 22,6 & & & & & & & 14 & 6,4 \\
\hline Sala de Estar e Jantar & 45 & 72,5 & 82 & 96,5 & 55 & 100 & 5 & 29,4 & 187 & 85,4 \\
\hline Sala de Televisão & 9 & 14,5 & 3 & 3,5 & 2 & 3,6 & & & 14 & 6,4 \\
\hline I Sala de Estar, Jantar e TV & & & 2 & 2,3 & & & & & 2 & 0,9 \\
\hline Home Theater & 3 & 4,8 & & & & & & & 3 & 1,3 \\
\hline Sala Íntima Familiar & 17 & 27,4 & & & & & & & 17 & 7,7 \\
\hline Escritório / Biblioteca & 5 & 8,0 & 4 & 4,7 & 1 & 1,8 & & & 10 & 4,5 \\
\hline Terraço Social & 62 & 100 & 84 & 98,8 & 48 & 87,2 & 7 & 41,1 & 201 & 91,8 \\
\hline Área Social e de Serviço & & & 1 & 1.1 & 1 & 1,8 & 9 & 52,9 & 11 & 5,0 \\
\hline
\end{tabular}




\section{Composição de Ambiente Projetos}

\begin{tabular}{|c|c|c|c|c|c|c|c|c|c|c|}
\hline \multirow[t]{2}{*}{ Ambientes } & \multicolumn{8}{|c|}{ Tipologia de Projeto } & \multirow[b]{2}{*}{ 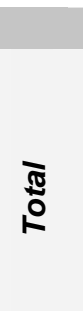 } & \multirow[b]{2}{*}{ de } \\
\hline & 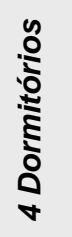 & do & 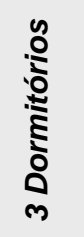 & de & 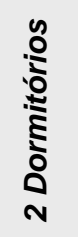 & do & 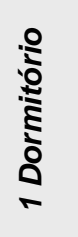 & do & & \\
\hline Amostra & 62 & 28,3 & 85 & 38,8 & 55 & 25,1 & 17 & 7,8 & 219 & 100 \\
\hline Cozinha & 36 & 58 & 34 & 40,0 & 35 & 63,6 & 5 & 29,4 & 110 & 50,2 \\
\hline Conjugado Copa e Cozinha & 26 & 41,9 & 50 & 58,8 & 19 & 34,5 & & & 95 & 43,3 \\
\hline Sala de Almoço / Copa & 22 & 35,5 & 1 & 1,17 & & & & & 23 & 10,5 \\
\hline Despensa de Cozinha & 24 & 38,7 & 4 & 4,7 & & & & & 28 & 12,8 \\
\hline Closet de Utensílios & 3 & 4,83 & & & & & & & 3 & 1,4 \\
\hline Adega & 1 & 1,61 & & & & & & & 1 & 0,5 \\
\hline
\end{tabular}

\section{Composição de Ambiente Projetos}

\section{Ambientes}

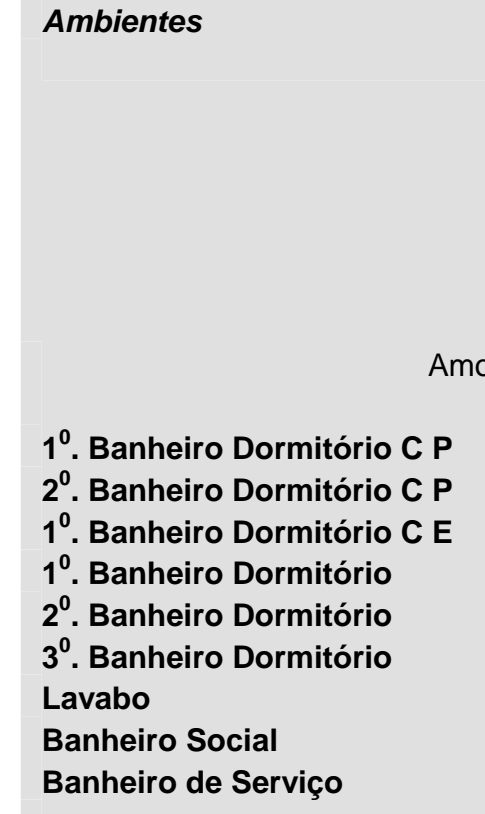

\section{Tipologia de Projeto}

\begin{tabular}{|c|c|c|c|c|c|c|c|c|c|}
\hline & & & Dloggla & Pros & & & & & \\
\hline 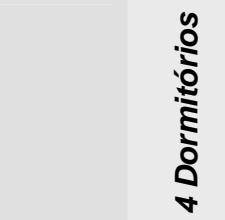 & do & 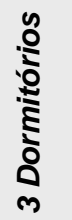 & de & 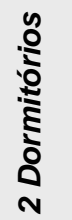 & de & 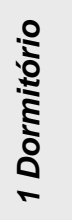 & de & $\begin{array}{l}\text { đ̊ } \\
\text { م }\end{array}$ & do \\
\hline nostra & 28,3 & 85 & 38,8 & 55 & 25,1 & 17 & 7,8 & 219 & 100 \\
\hline 60 & 96,7 & 73 & 85,9 & 33 & 60,0 & 6 & 35,3 & 172 & 78,5 \\
\hline 3 & 4,8 & & & & & & & 3 & 1,3 \\
\hline 4 & 6,4 & & & & & & & 4 & 1,8 \\
\hline 51 & 82,2 & 7 & 8,2 & 3 & 5,4 & & & 61 & 27,8 \\
\hline 15 & 24,2 & 7 & 8,2 & & & & & 22 & 10,0 \\
\hline 9 & 14,5 & & & & & & & 9 & 4,1 \\
\hline 54 & 87,1 & 25 & 29,4 & 3 & 5,4 & 1 & 5,9 & 83 & 37,9 \\
\hline 49 & 79,0 & 78 & 91,7 & 52 & 94,5 & 11 & 64,7 & 190 & 86,7 \\
\hline 58 & 93,5 & 55 & 64,7 & 9 & 16,3 & & & 122 & 55,7 \\
\hline
\end{tabular}




\section{Composição de Ambiente Projetos}

\begin{tabular}{|c|c|c|c|c|c|c|c|c|c|c|}
\hline \multirow[t]{2}{*}{ Ambientes } & \multicolumn{8}{|c|}{ Tipologia de Projeto } & \multirow[b]{2}{*}{ 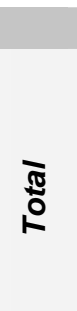 } & \multirow[b]{2}{*}{ de } \\
\hline & 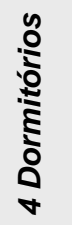 & de & 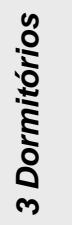 & de & 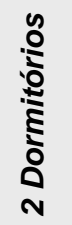 & de & 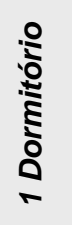 & de & & \\
\hline Amostra & 62 & 28,3 & 85 & 38,8 & 55 & 25,1 & 17 & 7,8 & 219 & 100 \\
\hline Área de Serviço & 62 & 100 & 85 & 100 & 55 & 100 & 6 & 35,3 & 208 & 95,0 \\
\hline Depósito de Serviço & 62 & 100 & 1 & 1,1 & & & & & 63 & 28,7 \\
\hline $1^{0}$. Dormitório de Serviço & 58 & 93,5 & 33 & 3,8 & 2 & 3,6 & & & 93 & 42,4 \\
\hline $2^{0}$. Dormitório de Serviço & 7 & 11,3 & & & & & & & 7 & 3,2 \\
\hline Banheiro de Serviço & 62 & 100 & 54 & 63,5 & 7 & 12,7 & & & 123 & 56,2 \\
\hline
\end{tabular}

\section{Composição de Ambiente Projetos}

\begin{tabular}{|c|c|c|c|c|c|c|c|c|c|c|}
\hline \multirow[t]{2}{*}{ Ambientes } & \multicolumn{8}{|c|}{ Tipologia de Projeto } & \multirow[b]{2}{*}{ 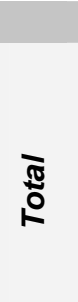 } & \multirow[b]{2}{*}{ de } \\
\hline & 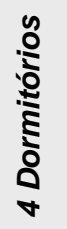 & do & 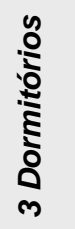 & do & 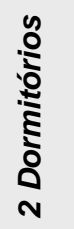 & do & 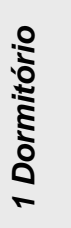 & do & & \\
\hline Amostra & 62 & 28,3 & 85 & 38,8 & 55 & 25,1 & 17 & 7,8 & 219 & 100 \\
\hline Hall de Distribuição & 57 & 91,9 & 82 & 96,5 & 49 & 89,1 & 1 & 5,9 & 189 & 86,3 \\
\hline Galeria & 10 & 16,1 & 50 & 58,8 & 31 & 56,3 & 3 & 17,6 & 94 & 42,9 \\
\hline 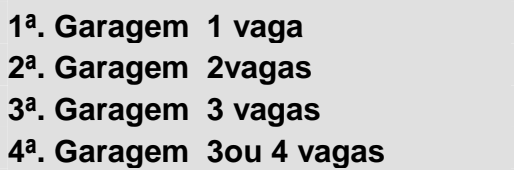 & & & & & & & & & & \\
\hline $\begin{array}{l}\text { Depósito de Garagem } \\
\text { Armário de garagem }\end{array}$ & 14 & & $\begin{array}{r}16 \\
1\end{array}$ & & & & & & 30 & 13,7 \\
\hline
\end{tabular}

Considerações:

3D e 2D -19 empreendimentos não informaram sobre número de vagas. 
FOLHAS 24 E 27 DA CAIXA ECONOMICA FEDERAL

O Manual Técnico da CEF poderá ser encontrado na íntegra no site da instituição financeira, consta desta pesquisa como anexo as folhas 24 e 27 , pois foram referenciadas no texto. 


\section{Em Condomínios Verticais}

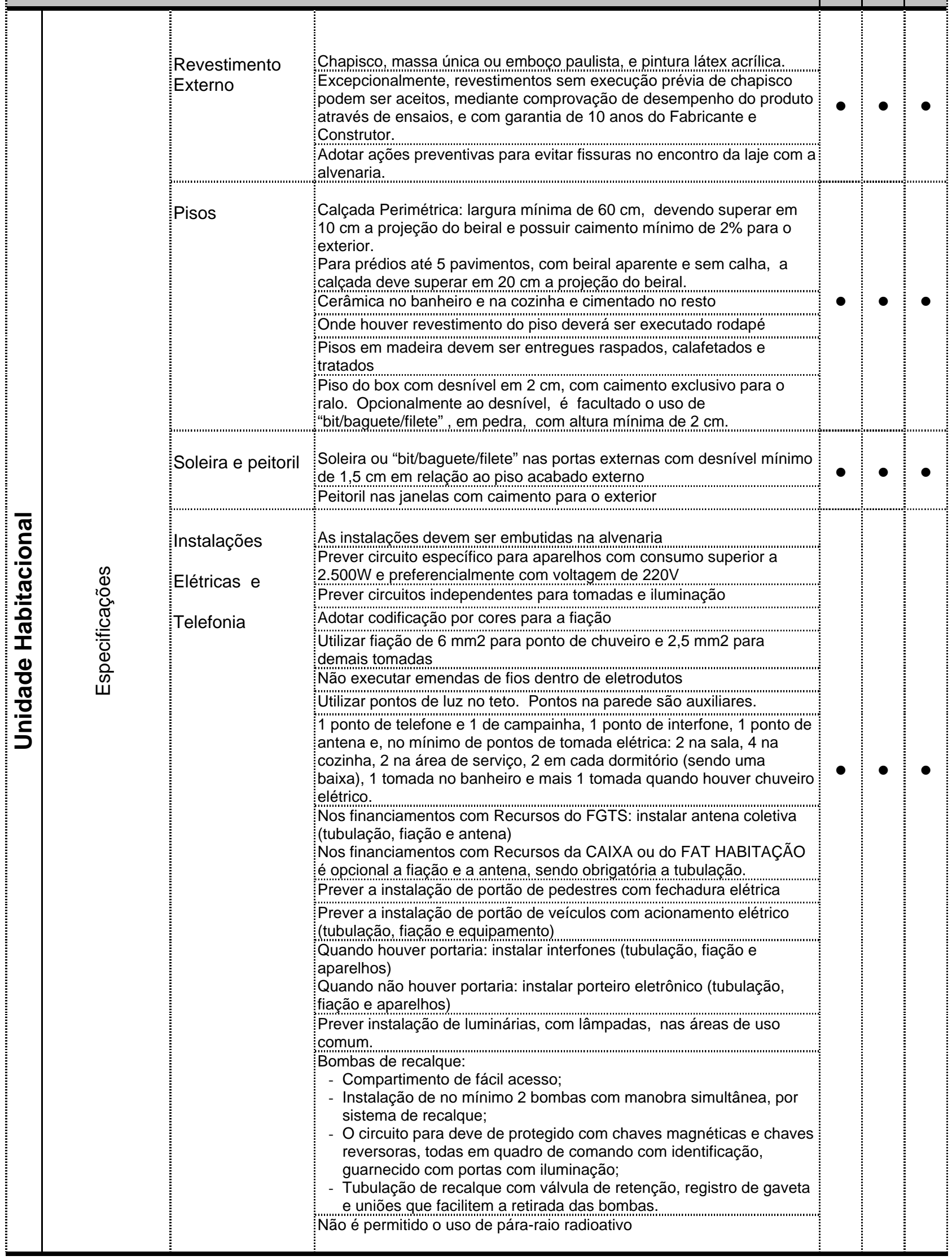




\begin{tabular}{|c|c|c|c|c|c|}
\hline \multirow{3}{*}{ AMBIENTE } & \multicolumn{3}{|c|}{ MOBILIÁRIO } & \multirow{3}{*}{$\underset{(\mathrm{m})}{\text { CIRCULAÇÃO }}$} & \multirow{3}{*}{ OBSERVAÇÕES } \\
\hline & \multirow{2}{*}{$\begin{array}{c}\text { MÓVEL OU } \\
\text { EQUIPAMENTO }\end{array}$} & \multicolumn{2}{|c|}{ DIMENSÕES $(m)$} & & \\
\hline & & Largura & Profund & & \\
\hline \multirow{8}{*}{ Sala de Estar } & Sofá de 3 lugares com braço & 1,70 & 0,70 & \multirow{6}{*}{$\begin{array}{l}\text { Capital: prever espaço de } \\
0,50 \mathrm{~m} \text { na frente do assento } \\
\text { para sentar, levantar e } \\
\text { circular. } \\
\text { CP e BU: prever } 0,60 \mathrm{~m} \text {. }\end{array}$} & \multirow{6}{*}{$\begin{array}{l}\text { Largura mínima sala de estar : } \\
2,40 \mathrm{~m} . \\
\text { Quantidade mínima de móveis } \\
\text { determinada pelo número de } \\
\text { habitantes da unidade. Os sofás } \\
\text { devem prever número de assentos } \\
\text { no mínimo igual ao número de } \\
\text { leitos. }\end{array}$} \\
\hline & Sofá de 2 lugares com braço & 1,20 & 0,70 & & \\
\hline & Poltrona com braço & 0,80 & 0,70 & & \\
\hline & Sofá de 3 lugares sem braço & 1,50 & 0,70 & & \\
\hline & Sofá de 2 lugares sem braço & 1,00 & 0,70 & & \\
\hline & Poltrona sem braço & 0,50 & 0,70 & & \\
\hline & Estante/armário para TV & 0,80 & 0,50 & Capital: $0,50 \mathrm{~m}$ & Espaço para o móvel obrigatório. \\
\hline & Mesinha centro ou cadeira apoio & - & 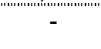 & - - - & Espaço para os móveis opcional." \\
\hline \multirow{6}{*}{$\begin{array}{l}\text { Sala Estar/Jantar } \\
\text { Sala de Jantar } \\
\text { Copa } \\
\text { Copa/Cozinha }\end{array}$} & Mesa redonda para 4 pessoas & $\varnothing 1,00$ & $\overline{-}$ & \multirow{6}{*}{$\begin{array}{l}\text { Circulação mínima de } 0,75 \mathrm{~m} \\
\text { a partir da borda da mesa } \\
\text { (espaço para afastar a } \\
\text { cadeira e levantar) }\end{array}$} & \multirow{6}{*}{$\begin{array}{l}\text { Largura mínima da sala de } \\
\text { estar/jantar e da sala de jantar } \\
\text { (isolada): } 2,40 \text { m. } \\
\text { Quantidade mínima: } 1 \text { mesa de } 4 \\
\text { pessoas. } \\
\text { Admite-se layout com cabeceira } \\
\text { de mesa encostada na parede, } \\
\text { desde que haja espaço suficiente } \\
\text { para seu afastamento, quando da } \\
\text { utilização }\end{array}$} \\
\hline & Mesa redonda para 6 pessoas & $\varnothing 1,20$ & 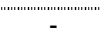 & & \\
\hline & Mesa quadrada para 4 pessoas & 1,00 & 1,00 & & \\
\hline & Mesa quadrada para 6 pessoas & 1,20 & 1,20 & & \\
\hline & Mesa retangular para 4 pessoas & 1,20 & 0,80 & & \\
\hline & Mesa retangular para 6 pessoas & 1,50 & 0,80 & & \\
\hline \multirow{5}{*}{ Cozinha } & Pia & 1,20 & 0,60 & \multirow{3}{*}{$\begin{array}{l}\text { Circulação mínima de } 0,90 \text { m } \\
\text { frontal à pia, fogão e } \\
\text { geladeira. }\end{array}$} & \multirow{3}{*}{$\begin{array}{l}\text { Largura mínima da cozinha: } \\
\text { 1,60 m. } \\
\text { Quantidade mínima: pia, fogão e } \\
\text { geladeira. }\end{array}$} \\
\hline & Fogão & 0,60 & 0,60 & & \\
\hline & Geladeira & 0,70 & 0,70 & & \\
\hline & Armário sobre a pia e gabinete & -" & 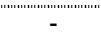 & (n) & Espaço para o móvel obrigatório. \\
\hline & Apoio para refeição ( 2 pessoas) & - & - & 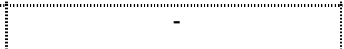 & Espaço para o móvel opcional." \\
\hline \multirow{3}{*}{$\begin{array}{l}\text { Dormitório Casal } \\
\text { (dormitório principal) }\end{array}$} & Cama de casal & 1,40 & 2,00 & \multirow{3}{*}{$\begin{array}{l}\text { Capital: circulação mínima } \\
\text { entre o mobiliário de } 0,50 \mathrm{~m} \text {. } \\
\text { CP e BU: mínimo } 0,60 \mathrm{~m} \text {. }\end{array}$} & \multirow{3}{*}{$\begin{array}{l}\text { Quantidade mínima: } 1 \text { cama, } 2 \\
\text { criados e } 1 \text { guarda-roupa. } \\
\text { Admite-se apenas } 1 \text { criado-mudo, } \\
\text { quando o segundo interferir na } \\
\text { abertura de portas do guarda- } \\
\text { roupa. }\end{array}$} \\
\hline & Criado-mudo & 0,50 & 0,50 & & \\
\hline & Guarda-roupa & 1,60 & " 0,55 & & \\
\hline \multirow{4}{*}{$\begin{array}{l}\text { Dormitório para } 2 \\
\text { Pessoas } \\
\left(2^{\circ} \text { dormitório }\right)\end{array}$} & Duas camas de solteiro & 0,80 & 2,00 & \multirow{3}{*}{$\begin{array}{l}\text { Circulação mínima entre as } \\
\text { camas: } 0,80 \mathrm{~m} \text {. } \\
\text { Demais circulações: } 0,50 \mathrm{~m} \\
\text { na Capital e } 0,60 \mathrm{~m} \text { em CP e } \\
\text { BU. }\end{array}$} & \multirow{3}{*}{$\begin{array}{l}\text { Quantidade mínima: } 2 \text { camas, } 1 \\
\text { criado e } 1 \text { guarda-roupa. } \\
\text { Admite-se a substituição do criado- } \\
\text { mudo por mesa de estudo. }\end{array}$} \\
\hline & Criado-mudo & 0,50 & 0,50 & & \\
\hline & Guarda-roupa & 1,60 & 0,55 & & \\
\hline & Mesa de estudo & 0,80 & 0,60 & - & Espaço para o móvel opcional. \\
\hline \multirow{4}{*}{$\begin{array}{l}\text { Dormitório para } 1 \\
\text { Pessoa } \\
\text { ( } 3^{\circ} \text { dormitório) }\end{array}$} & Cama de solteiro & 0,80 & 2,00 & \multirow{3}{*}{$\begin{array}{l}\text { Capital: circulação mínima } \\
\text { entre o mobiliário de } 0,50 \mathrm{~m} \text {. } \\
\text { CP e BU: mínimo } 0,60 \mathrm{~m} \text {. }\end{array}$} & \multirow{3}{*}{$\begin{array}{l}\text { Dimensão mínima: a que permita } \\
\text { inscrever um círculo de } \varnothing 2,10 \mathrm{~m} \text {. } \\
\text { Quantidade mínima: } 1 \text { cama, } 1 \\
\text { criado e } 1 \text { guarda-roupa. }\end{array}$} \\
\hline & Criado-mudo & 0,50 & 0,50 & & \\
\hline & Armário & 1,20 & 0,55 & & \\
\hline & Mesa de estudo & 0,80 & 0,60 & "'"'"' & Espaço para o móvel opcional. \\
\hline \multirow{7}{*}{ Banheiro } & Lavatório & tamant & médio & & \\
\hline & Lavatório com bancada & 0,80 & 0,55 & frontal ao lavatório, vaso e & $1,20 \mathrm{~m}$. \\
\hline & Vaso sanitário (caixa acoplada) & 0,60 & 0,70 & $\begin{array}{l}\text { bidê. Admite-se circulação } \\
\text { de } 0,45 \mathrm{~m} \text {, quando vaso }\end{array}$ & Quantidade mínima: 1 lavatório, 1 \\
\hline & Vaso sanitário & 0,60 & 0,60 & sanitário de $0,70 \mathrm{~m}$. & vaso e 1 box. \\
\hline & Box quadrado & 0,80 & 0,80 & & \\
\hline & Box retangular & 0,70 & 0,90 & & \\
\hline & Bidê & 0,60 & 0,60 & & Peça opcional." \\
\hline & Tanque & 0,60 & 0,55 & Circulação mínima de $0,50 \mathrm{~m}$ & Quantidade mínima: 1 tanque e 1 \\
\hline Area de serviço & Máquina de lavar roupa & 0,60 & 0,65 & $\begin{array}{l}\text { trontal ao tanque e máquina } \\
\text { de lavar. }\end{array}$ & $\begin{array}{l}\text { máquina, (tanque de no mínimo } 20 \\
\text { litros). }\end{array}$ \\
\hline Corredor/Escada & & 0,80 & - & - & \\
\hline
\end{tabular}


Trabalho Programado

Pesquisa de Composição de Ambientes, Mobiliário e Equipamentos da Habitação
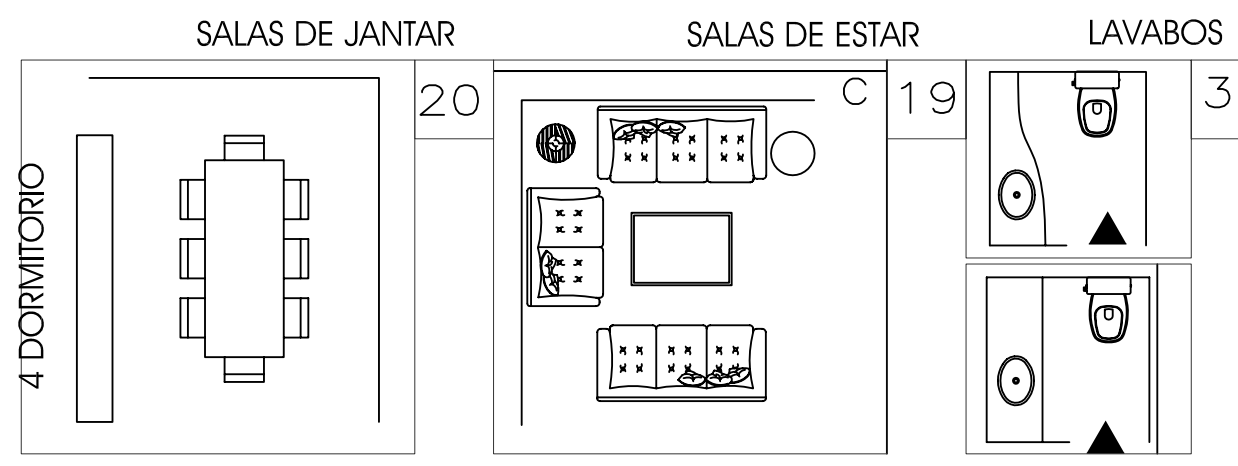

D. CASAL
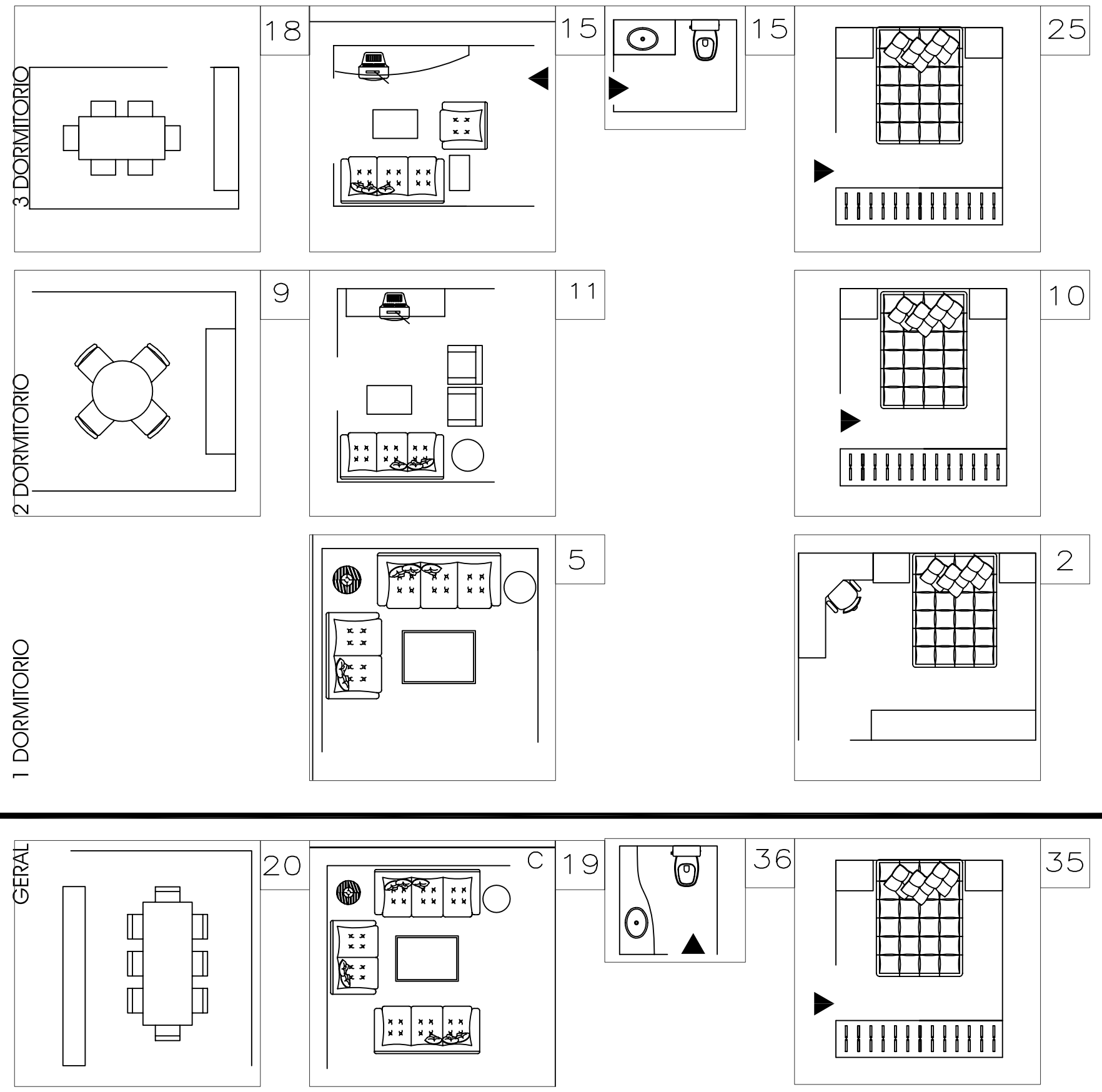
Trabalho Programado

Pesquisa de Composição de Ambientes, Mobiliário e Equipamentos da Habitação
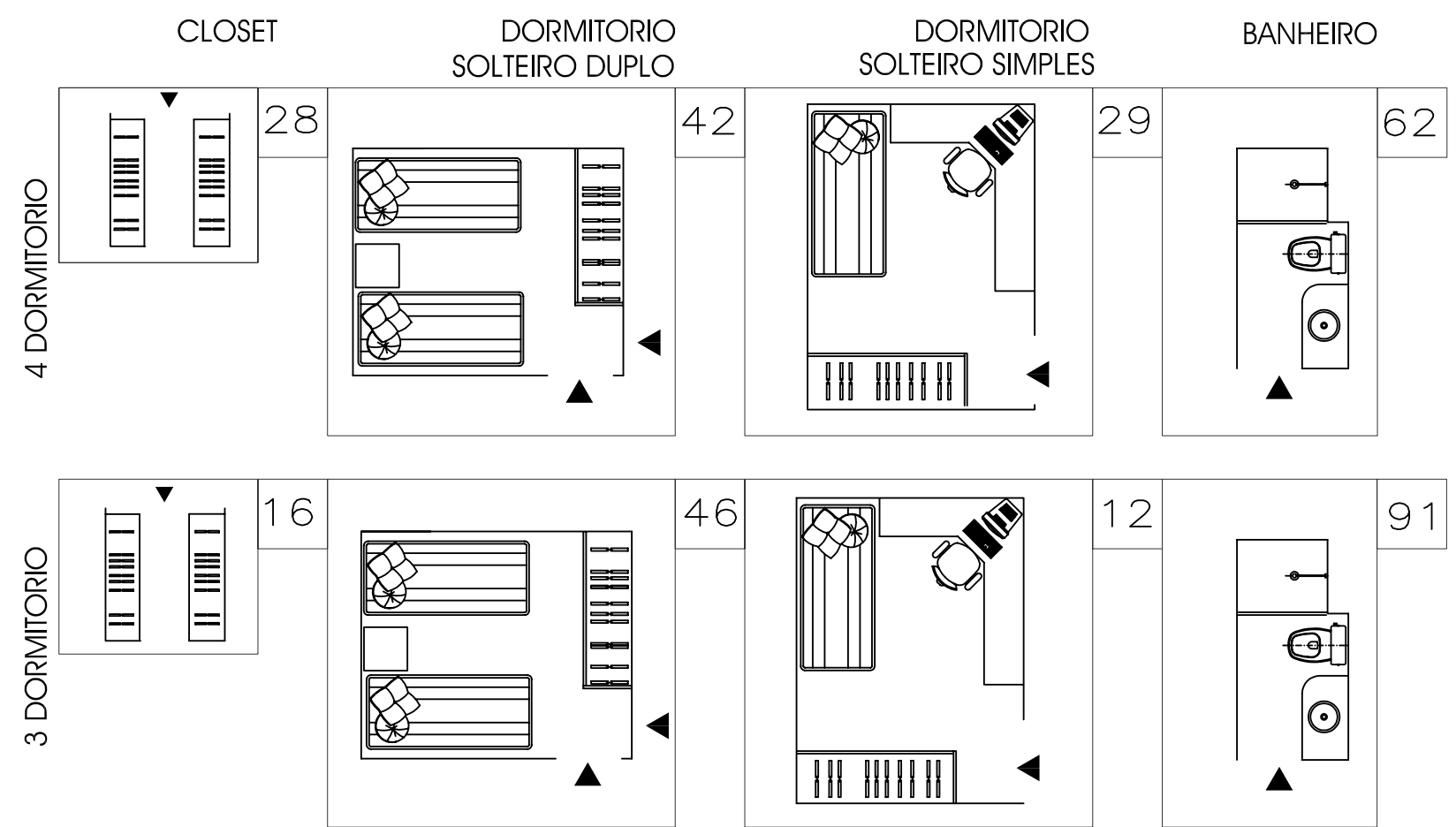

91
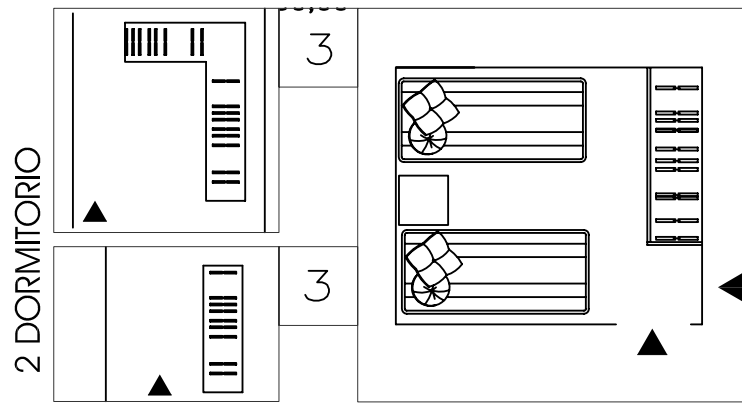

16
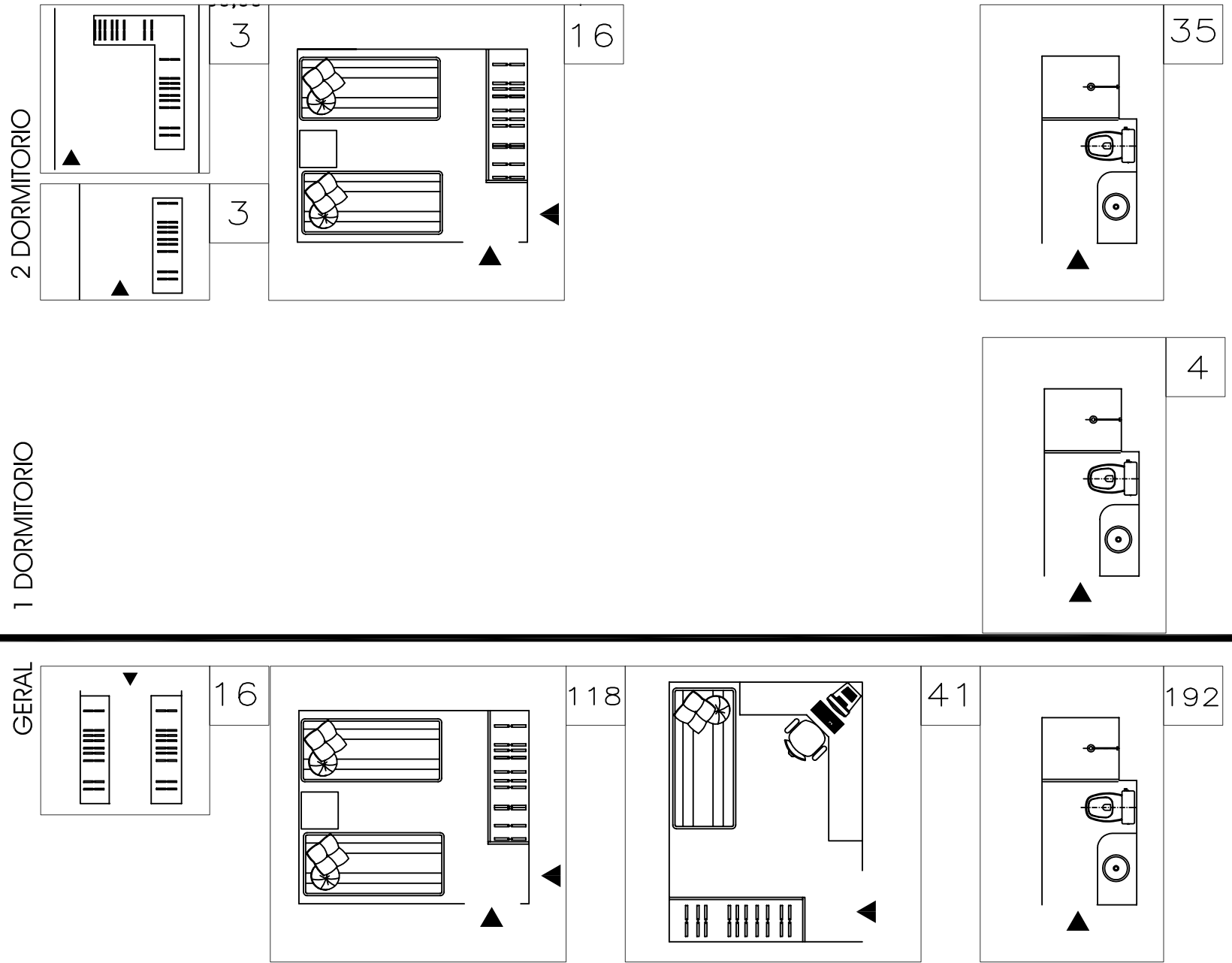

41 


\section{Trabalho Programado}

Pesquisa de Composição de Ambientes, Mobiliário e Equipamentos da Habitação
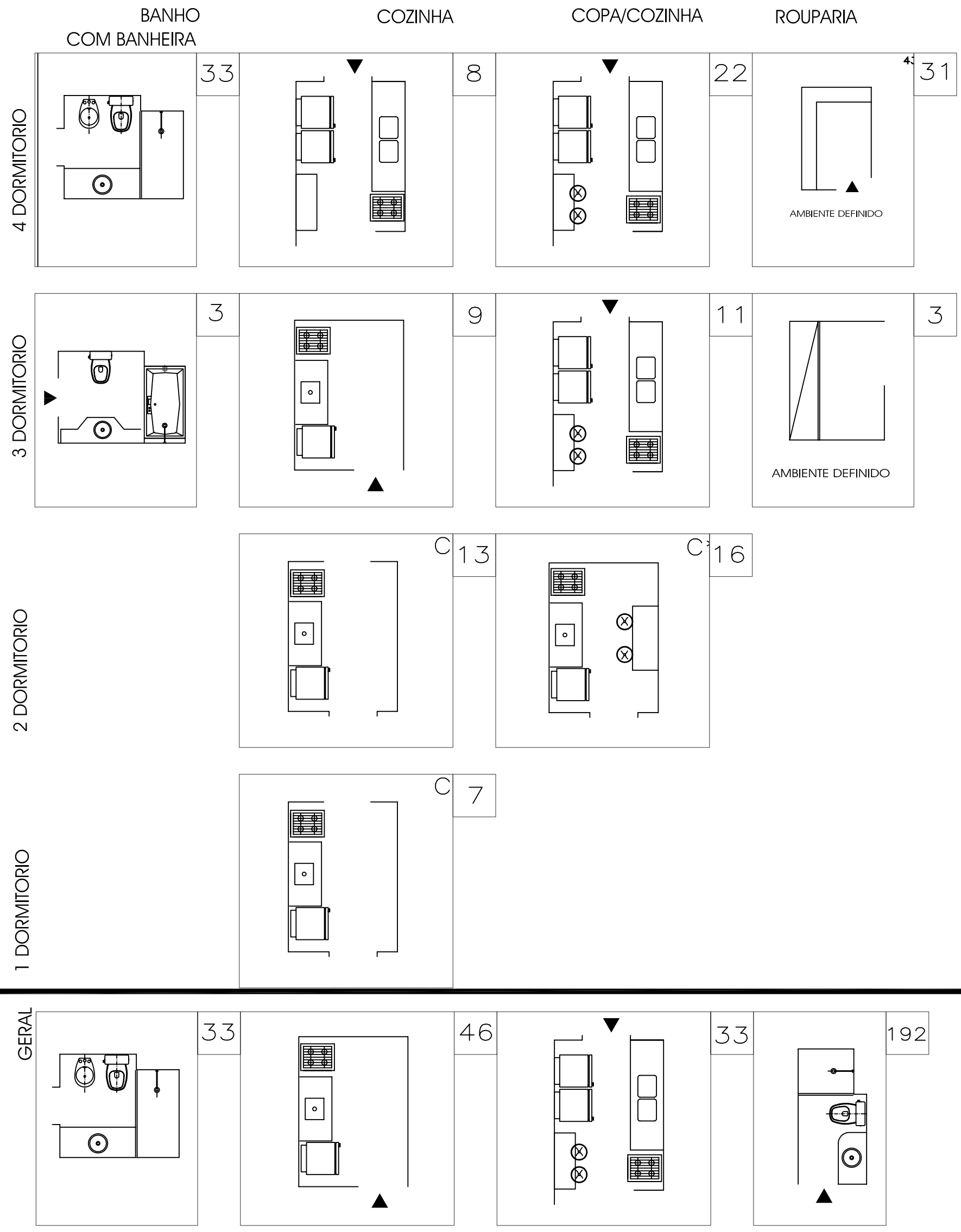

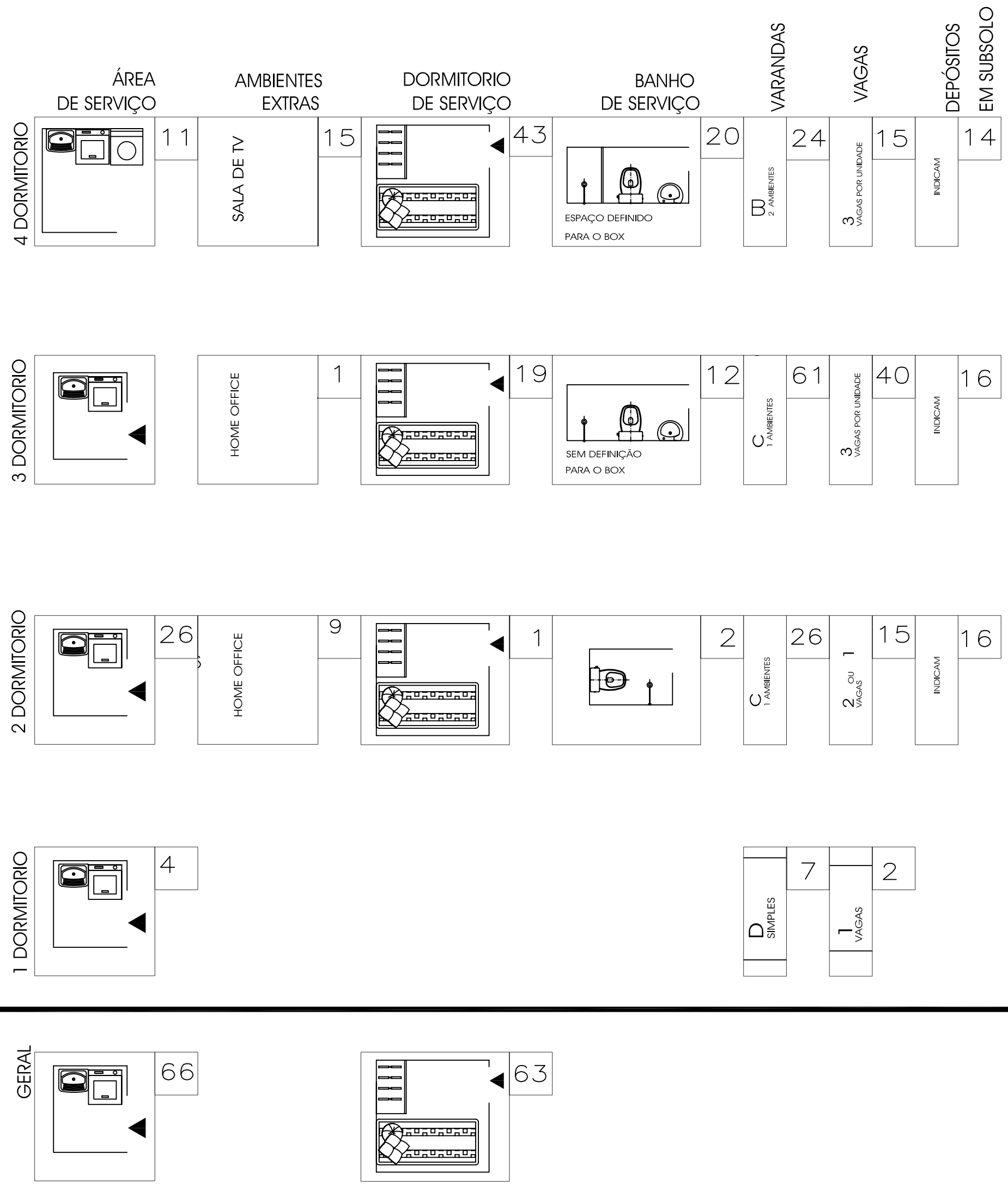


\section{Função | Sistema de Atividades | Atividades}

\begin{tabular}{|c|c|}
\hline Função & Sistema de Atividades \\
\hline 1. Repouso Pessoal & $\begin{array}{l}\text { a) Dormir | descanso de casal } \\
\text { b) Dormir | descanso individual/duplo } \\
\text { c) Dormir | descanso de crianças } \\
\text { d) Convalescer } \\
\text { e) Permanência em reservado }\end{array}$ \\
\hline 2. Preparo de Refeições & $\begin{array}{l}\text { a) Preparação de alimentos } \\
\text { b) Arrumação de louças e utensílios } \\
\text { c) Tratamento de resíduos }\end{array}$ \\
\hline 3. Refeições & $\begin{array}{l}\text { a) Refeições correntes } \\
\text { b) Refeições formais } \\
\text { c) Estar à mesa }\end{array}$ \\
\hline 4. Estar | Lazer & $\begin{array}{l}\text { a) Estar passivo } \\
\text { b) Receber visitas } \\
\text { c) Recreio de crianças } \\
\text { d) Diversão de jovens e adultos } \\
\text { e) Lazer em família } \\
\text { f) Eventos sociais em grupo } \\
\text { g) Estar em ambiente externo privado } \\
\text { h) Receber em ambiente externo privado } \\
\text { i) Lazer em ambiente externo privado }\end{array}$ \\
\hline 5. Estudo | Trabalho & $\begin{array}{l}\text { a) Estudo de jovens } \\
\text { b) Estudo de adultos } \\
\text { c) Trabalho de adultos }\end{array}$ \\
\hline 6. Higiene Pessoal & $\begin{array}{l}\text { a) Lavagens corporais } \\
\text { b) Funções vitais } \\
\text { c) Cuidados pessoais }\end{array}$ \\
\hline $\begin{array}{l}\text { 7. Manutenção e Arrumação } \\
\text { (Gestão Doméstica) }\end{array}$ & $\begin{array}{l}\text { a) Limpeza } \\
\text { b) Arrumação geral } \\
\text { c) Manutenção geral } \\
\text { d) Controle ambiental } \\
\text { e) Vigilância e segurança } \\
\text { f) Tratamento de resíduos domésticos } \\
\text { g) Cuidado de animais domésticos }\end{array}$ \\
\hline 8. Tratamento de Roupa & $\begin{array}{l}\text { a) Lavar roupa } \\
\text { b) Secar roupa } \\
\text { c) Passar roupa } \\
\text { d) Costurar roupa } \\
\text { e) Cuidar de calçados }\end{array}$ \\
\hline 9. Circulação & $\begin{array}{l}\text { a) Entrada/saída } \\
\text { b) Comunicação/separação }\end{array}$ \\
\hline 10. Estacionamento & $\begin{array}{l}\text { a) Uso do veículo } \\
\text { b) Manutenção do veículo }\end{array}$ \\
\hline
\end{tabular}


ANEXO 6 - FOLHA 1

T2 APARTAMENTOS DE 2 DORMITÓRIOS

PLANTAS UTILIZADAS PARA A APLICAÇÃO DOS MÉTODOS DE AVALIAÇÕES

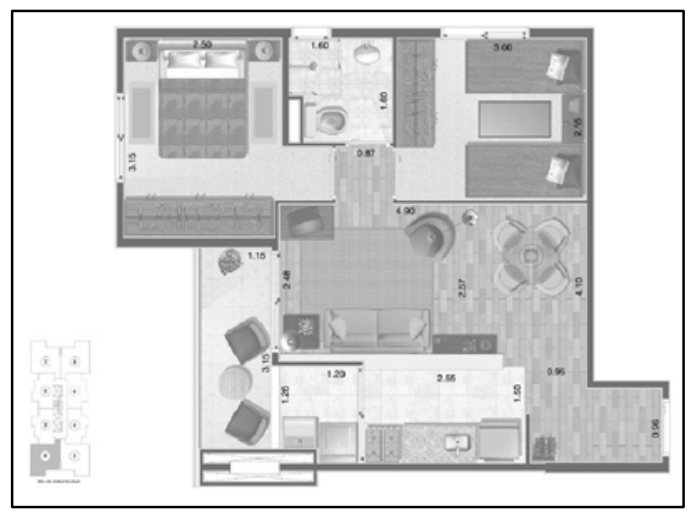

O1 HOME FLEX ITAIM

Area Privativa $=51,17 \mathrm{~m}^{2}$

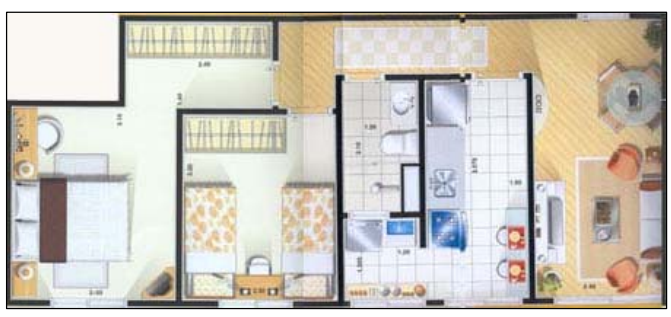

O2 SPAZIO NORTE FINAIS 5 E 6 Area Privativa $=51,96 \mathrm{~m}^{2}$

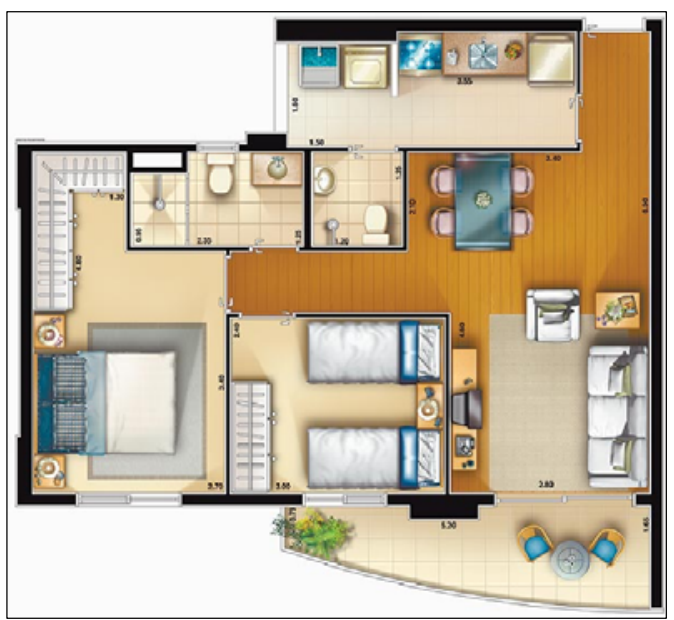

O4 NOVA MOOCA T2 Area Privativa $=61,66 \mathrm{~m}^{2}$

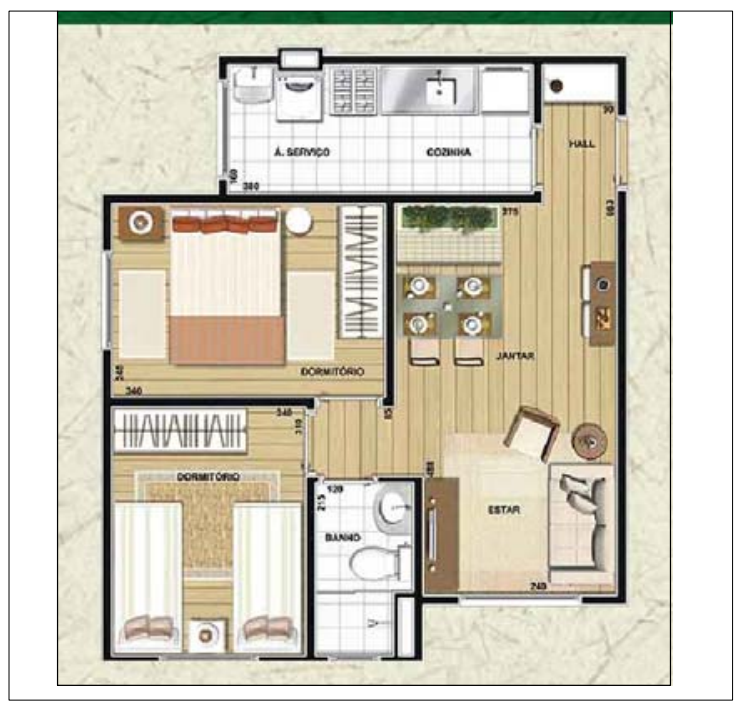

03 ECOVITA FINAIS 3E6

Area Privativa $=47,02 \mathrm{~m}^{2}$

05 ECOVITTA FINAIS 1,2,3 E4 Area Privativa $=45,54 \mathrm{~m}^{2}$ 
ANEXO 6 - FOLHA 2

T3 APARTAMENTOS DE 3 DORMITÓRIOS

PLANTAS UTILIZADAS PARA A APLICAÇÃO DOS MÉTODOS DE AVALIAÇÕES

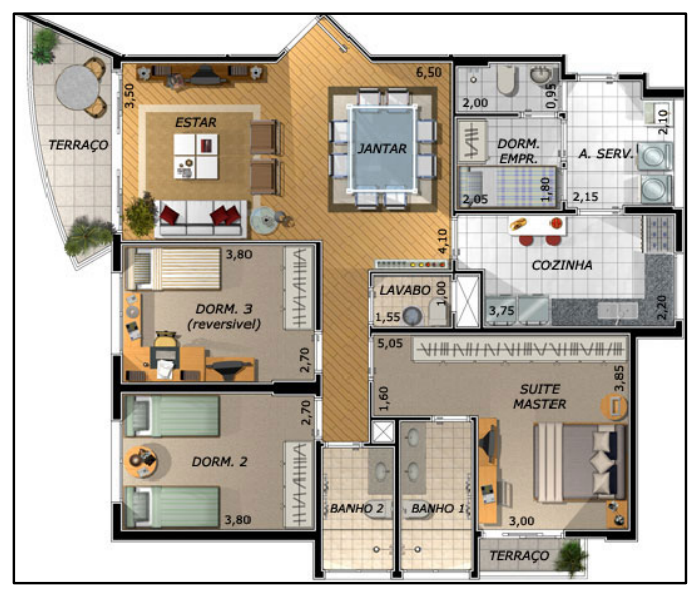

01 EDIFICIO DIANA

Area Privativa $=108,97 \mathrm{~m}^{2}$

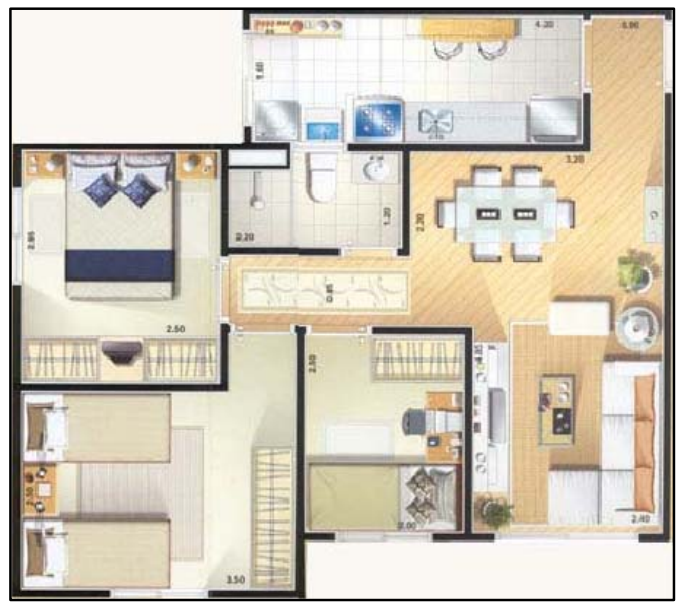

O2 SPAZIO NORTE

Area Privativa $=56,09 \mathrm{~m}^{2}$

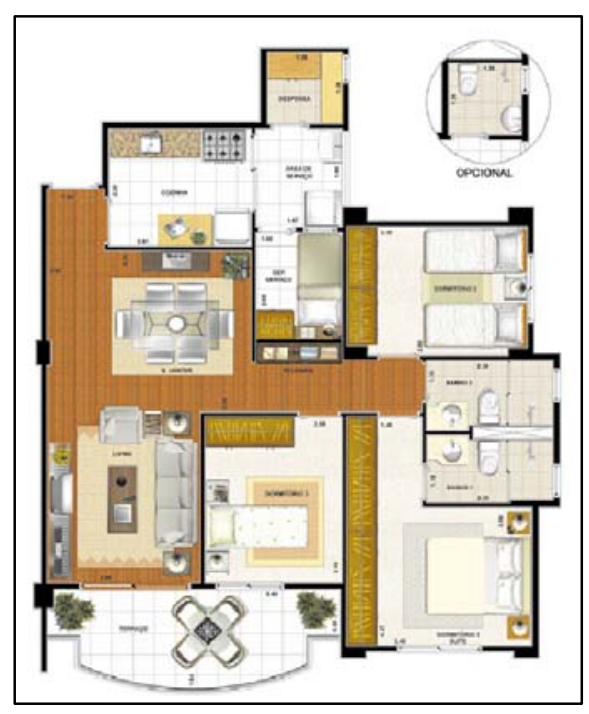

O3 BOSQUES DE SÃO FRANCISCO Area Privativa $=90,00 \mathrm{~m}^{2}$

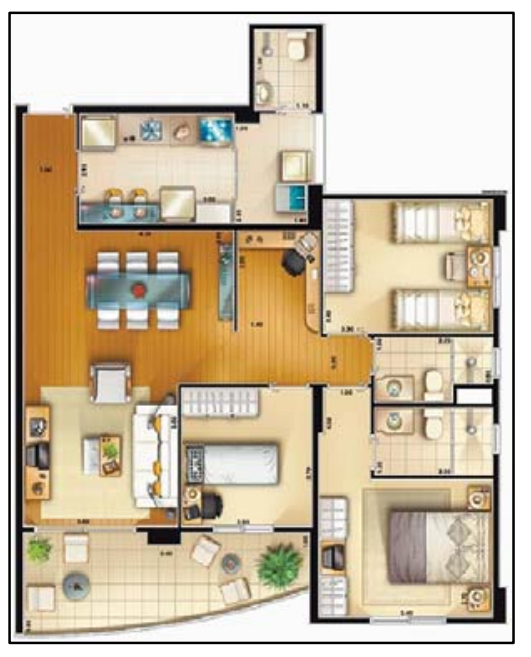

01 NOVA MOOCA 3D Area Privativa $=92,00 \mathrm{~m}^{2}$

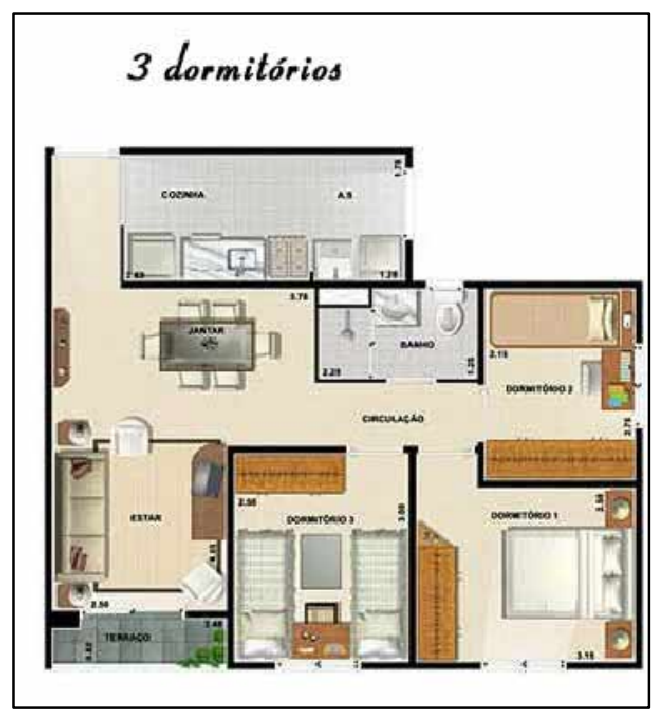

05 CITY PARK

Area Privativa $=61,20 \mathrm{~m}^{2}$ 
ANEXO 6 - FOLHA 4

T4 APARTAMENTOS DE 4 DORMITÓRIOS

PLANTAS UTILIZADAS PARA A APLICAÇÃO DOS MÉTODOS DE AVALIAÇÕES

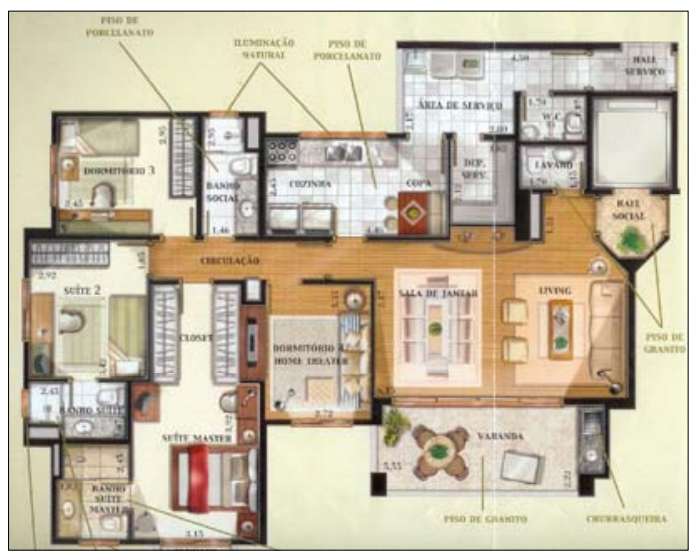

n० 113 CLASSIC CONDOMINIUM CLUB Area Privativa $=137,00 \mathrm{~m}^{2}$

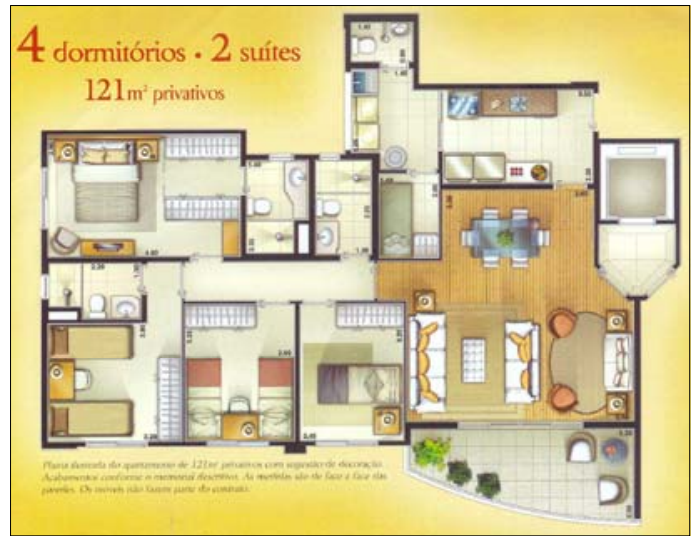

n० 165 PREMIERE

Area Privativa $=121,00 \mathrm{~m}^{2}$

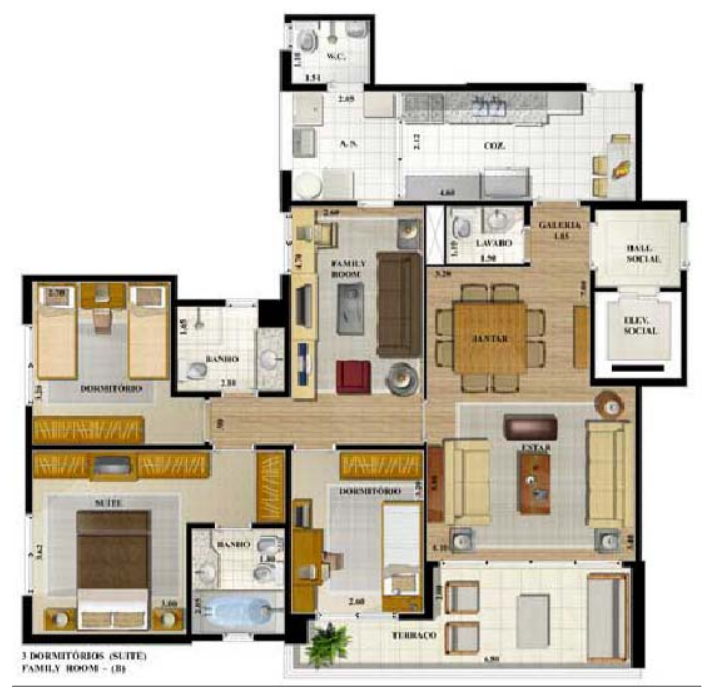

$n^{\circ} 166$ VILLAGIO ARANDU

Area Privativa $=116,00 \mathrm{~m}^{2}$

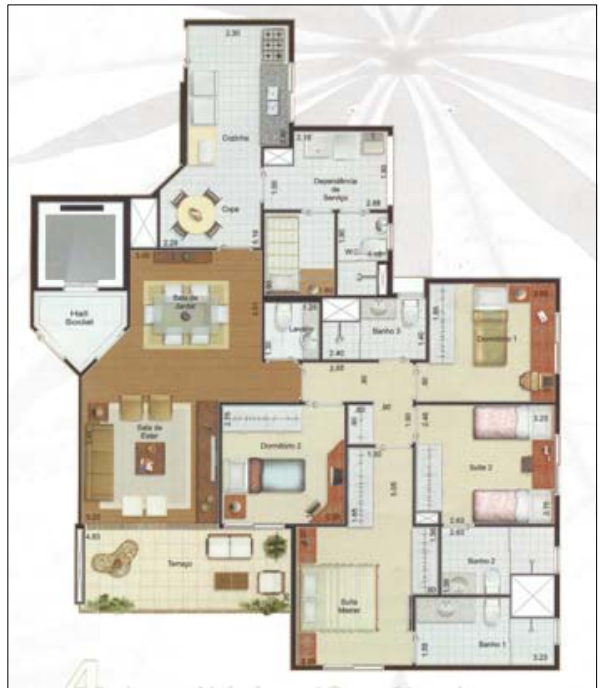

n० 167 ILE ECOLIFE Area Privativa $=118,00 \mathrm{~m}^{2}$

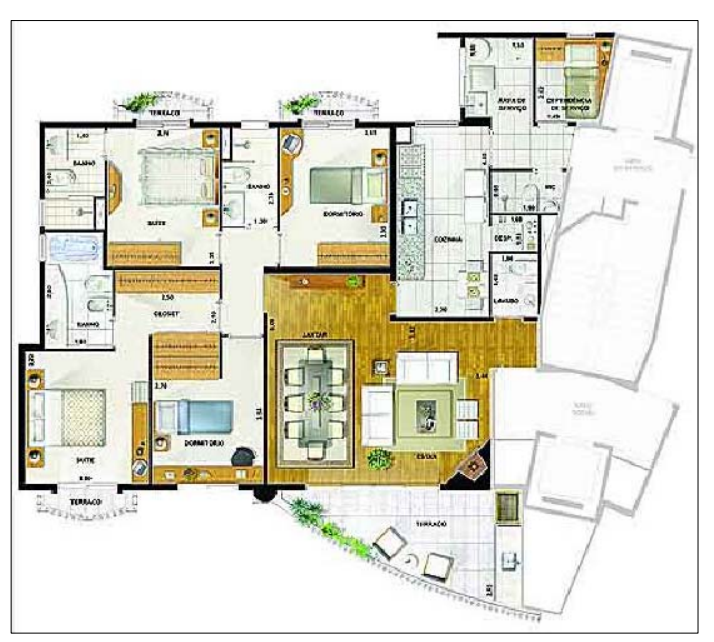

Planta - Arandu -n 166 Area Privativa $=116,00 \mathrm{~m}^{2}$ 


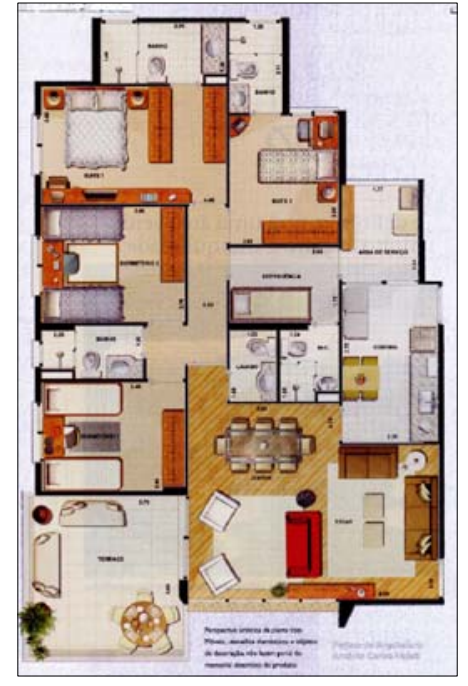

n० 07 THE DREAM

Area Privativa $=133,10 \mathrm{~m}^{2}$

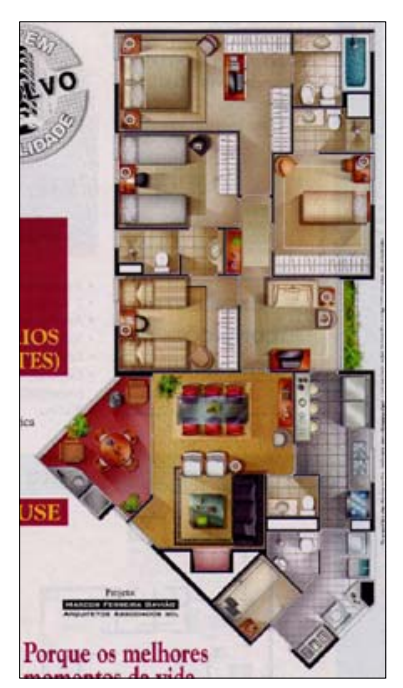

NO 12 BALTIMORE

Area Privativa $=125,00 \mathrm{~m}^{2}$

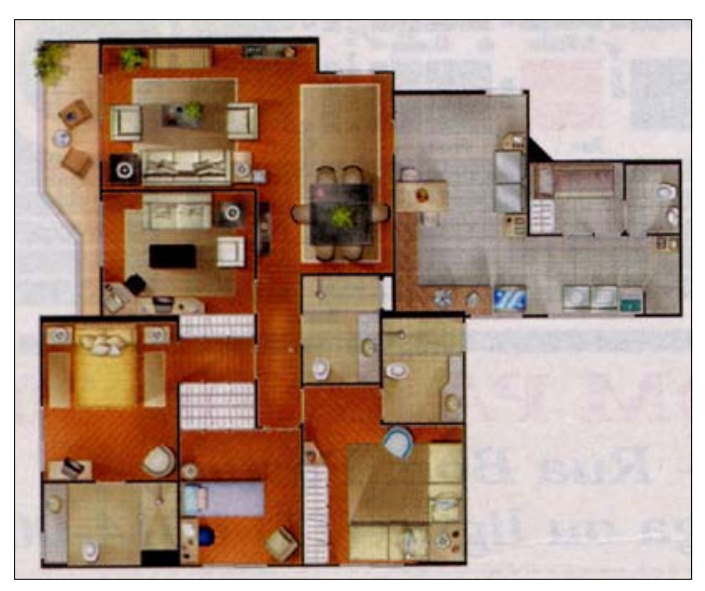

NO 18 PALÁCIO DA INDEPENDENCIA Area Privativa $=135,00 \mathrm{~m}^{2}$

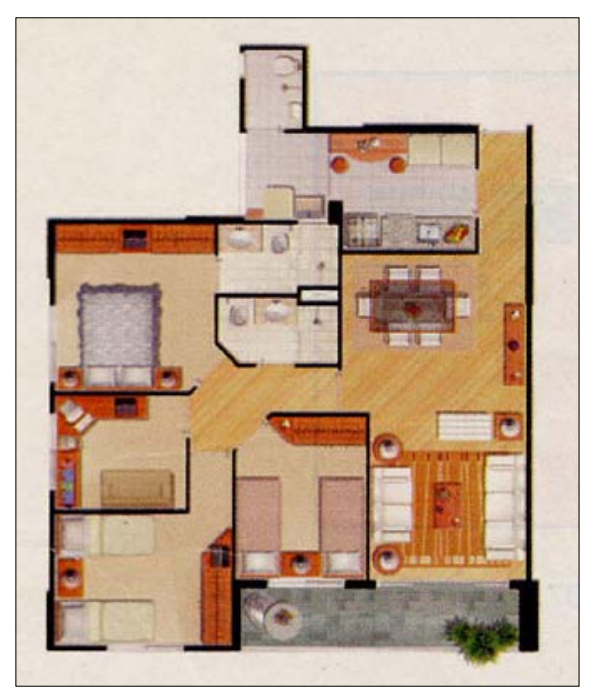

NO 19 JARDINS DE LUXEMBURGO Area Privativa $=90,00 \mathrm{~m}^{2}$

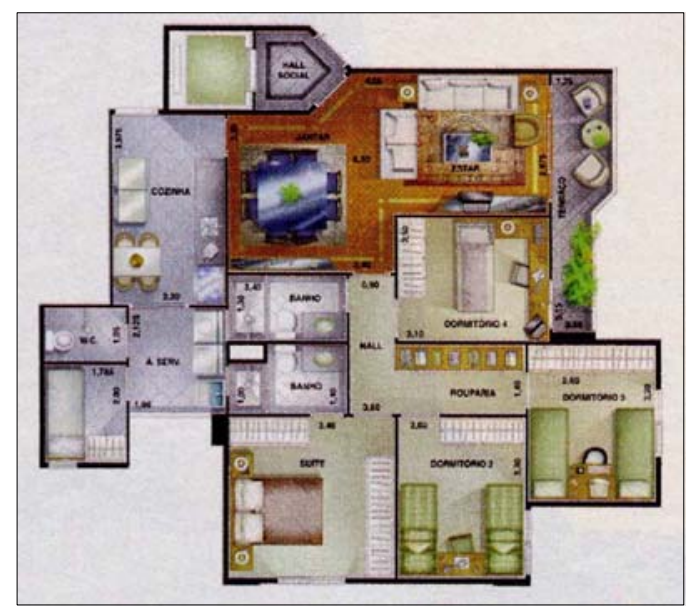

n० 49 EDIFICIO GENEVE Area Privativa $=104,61 \mathrm{~m}^{2}$ 


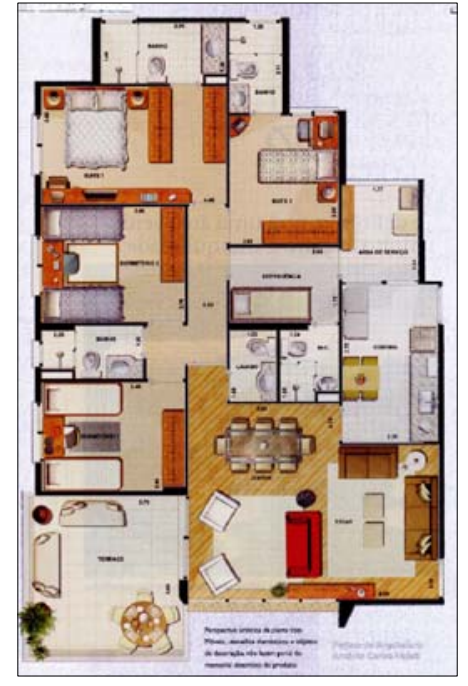

n० 07 THE DREAM

Area Privativa $=133,10 \mathrm{~m}^{2}$

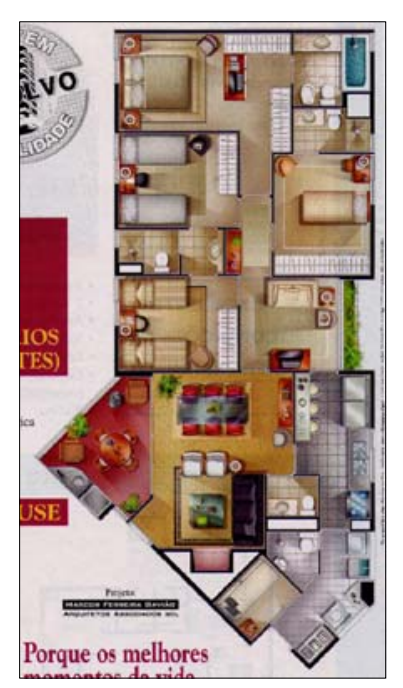

NO 12 BALTIMORE

Area Privativa $=125,00 \mathrm{~m}^{2}$

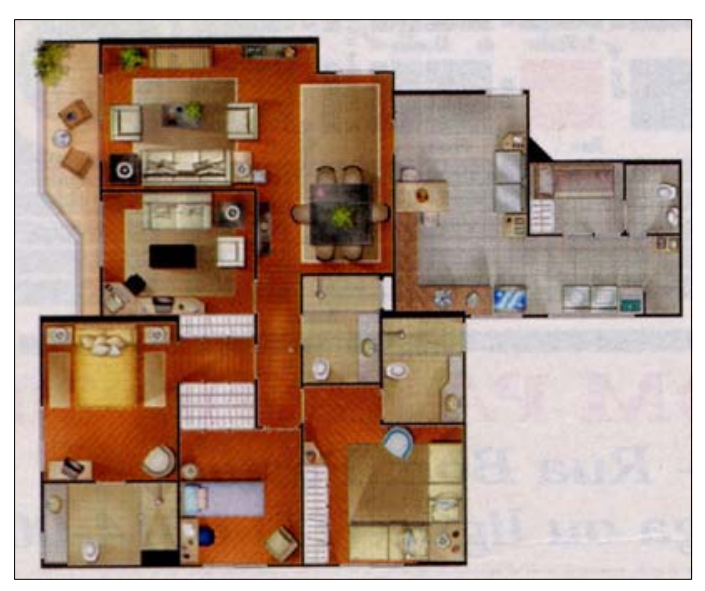

NO 18 PALÁCIO DA INDEPENDENCIA Area Privativa $=135,00 \mathrm{~m}^{2}$

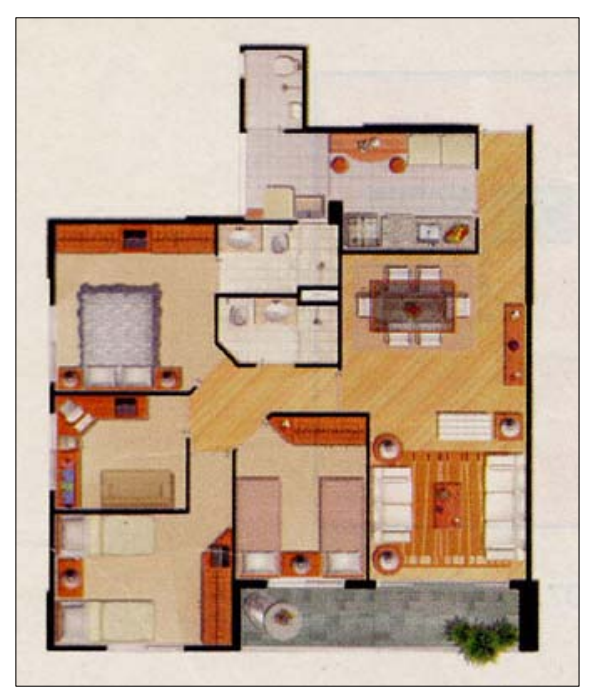

NO 19 JARDINS DE LUXEMBURGO Area Privativa $=90,00 \mathrm{~m}^{2}$

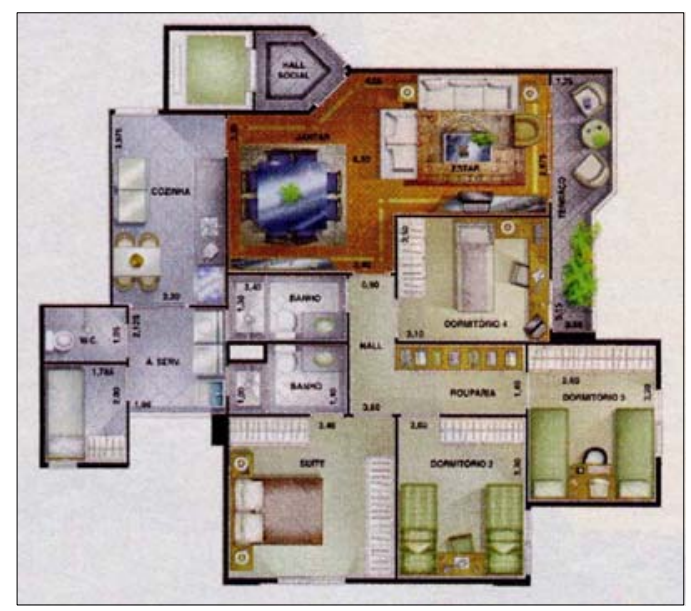

n० 49 EDIFICIO GENEVE Area Privativa $=104,61 \mathrm{~m}^{2}$ 
ANEXO 6 - FOLHA 5

T4 APARTAMENTOS DE 4 DORMITÓRIOS

PLANTAS UTILIZADAS PARA A APLICAÇÃO DOS MÉTODOS DE AVALIAÇÕES

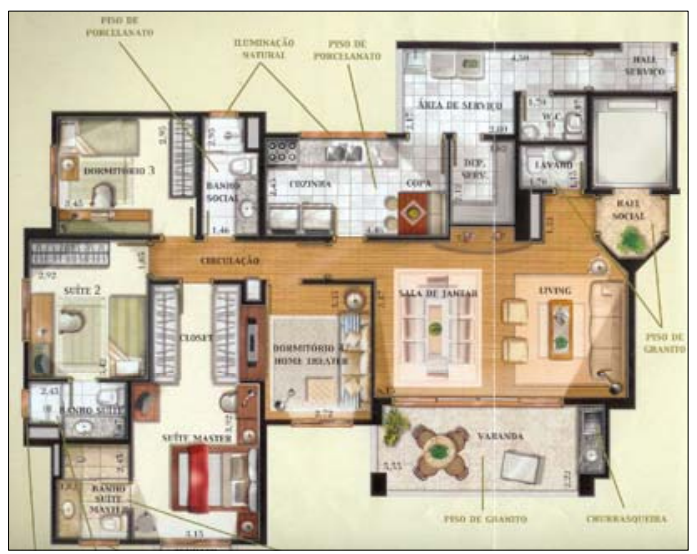

n० 113 CLASSIC CONDOMINIUM CLUB Area Privativa $=137,00 \mathrm{~m}^{2}$

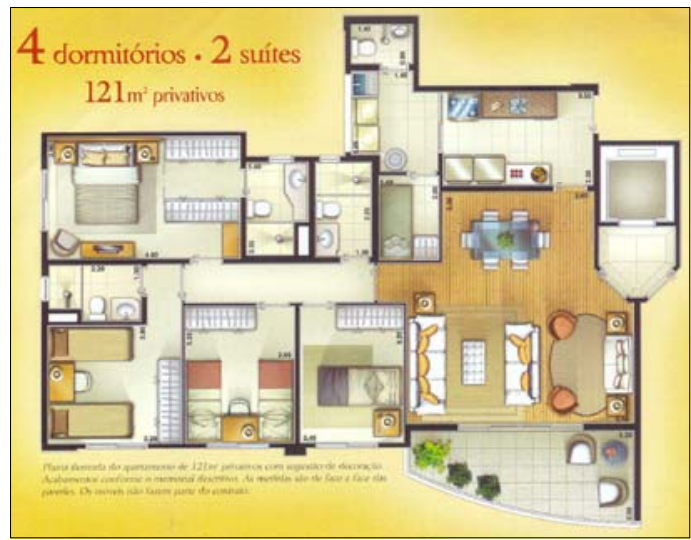

n० 165 PREMIERE

Area Privativa $=121,00 \mathrm{~m}^{2}$

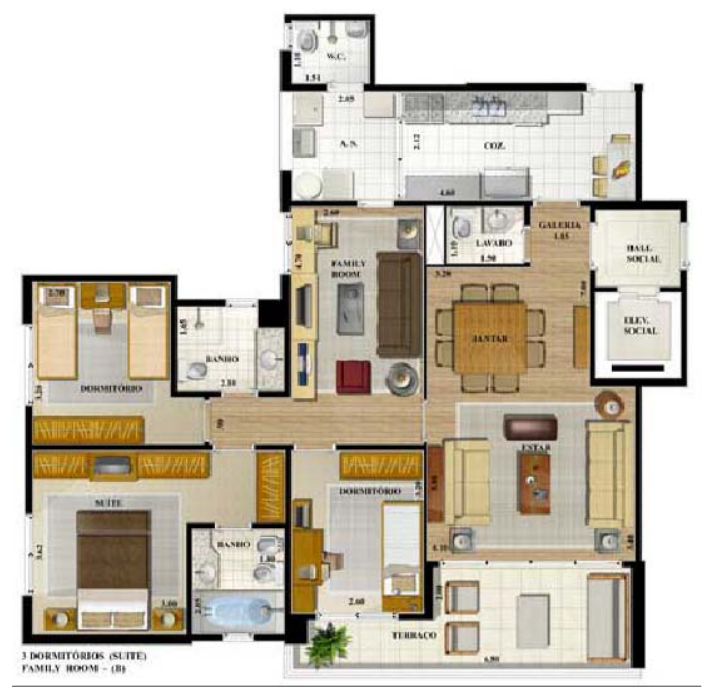

$n^{\circ} 166$ VILLAGIO ARANDU

Area Privativa $=116,00 \mathrm{~m}^{2}$

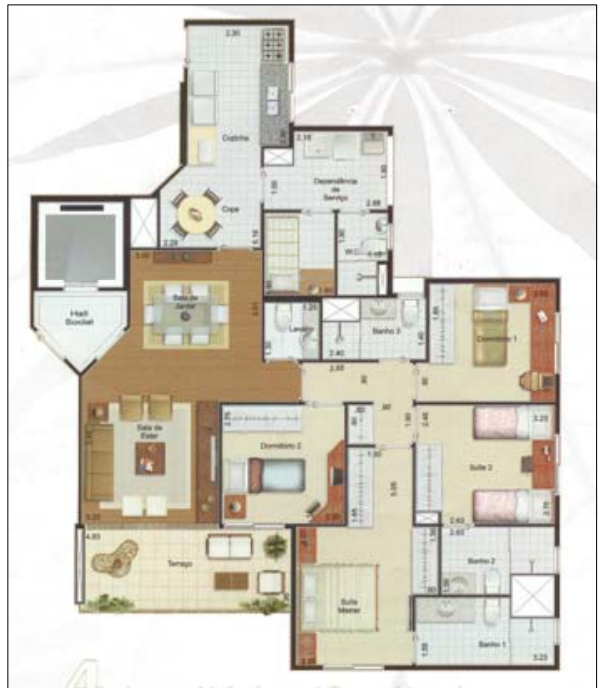

$n^{\circ} 167$ ILE ECOLIFE Area Privativa $=118,00 \mathrm{~m}^{2}$

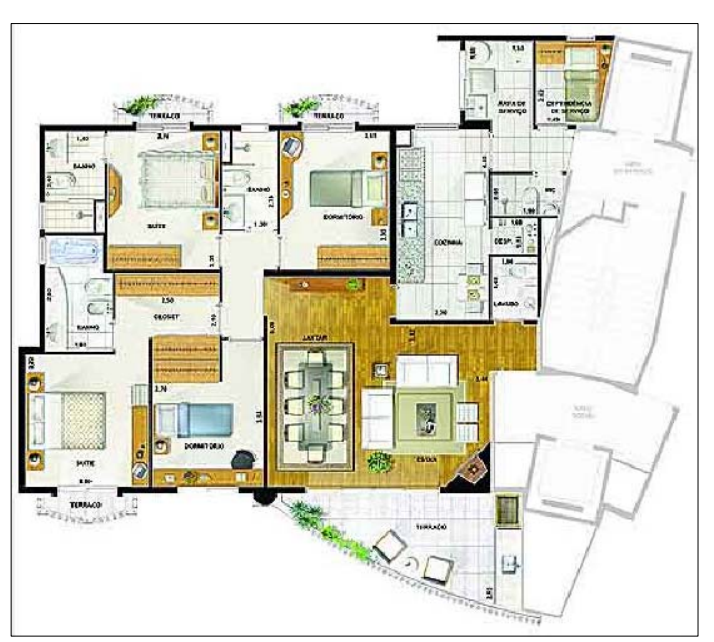

Planta - Arandu -n 166 Area Privativa $=116,00 \mathrm{~m}^{2}$ 
ANEXO 7- DESENHOS UTILIZADOS - ESPAÇOS

DE ATIVIDADES

FONTE BOUERI -2004

TRATAMENTO

DE ROUPA

\begin{tabular}{|c|c|}
\hline$(1 ;)$ & TANQUE PEQUENO \\
\hline & TANQUE GRANDE \\
\hline & $\begin{array}{l}\text { MAQUINA DE LAVAR } \\
\text { ROUPA }\end{array}$ \\
\hline & $\begin{array}{l}\text { MAQUINA DE SECAR } \\
\text { ROUPA }\end{array}$ \\
\hline & $\begin{array}{l}\text { TABUA DE PASSAR } \\
\text { A FERRO }\end{array}$ \\
\hline & $\begin{array}{l}\text { MODULO ARMARIO / } \\
\text { MANUTENCCAO E } \\
\text { ARRUMAÇAO }\end{array}$ \\
\hline
\end{tabular}

HIGIENE

PESSOAL

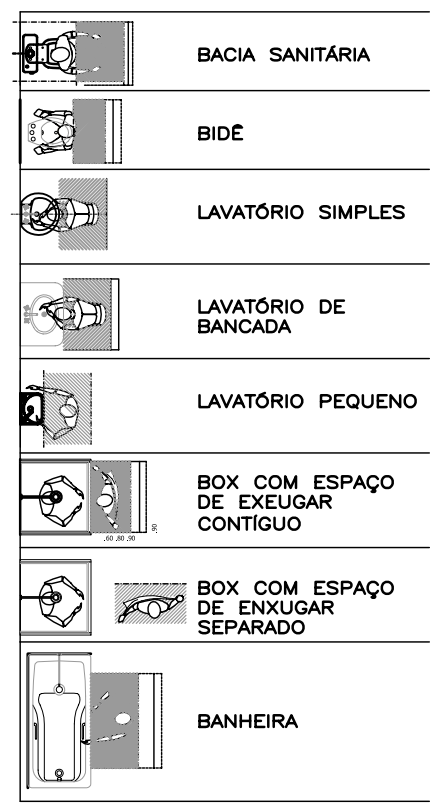

PREPARO DE

REFEIÇÕES

\begin{tabular}{|ll|}
\hline S) DID & $\begin{array}{l}1 \text { MODULO DE } \\
\text { ARMARIO DE } \\
\text { COZINHA }\end{array}$ \\
\hline & $\begin{array}{l}\text { MAQUINA DE LAVAR } \\
\text { LOUÇA }\end{array}$ \\
\hline FALÇAO DE \\
\hline TRABALHO SENTADO
\end{tabular}

ESTAR E

LAZER

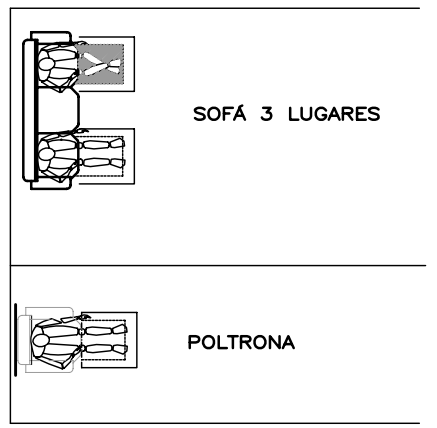

REPOUSO

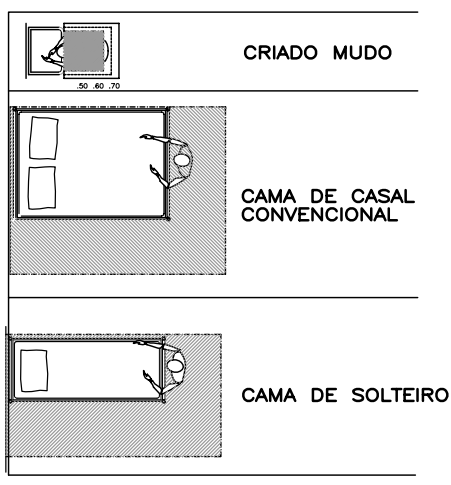

MANUTENÇÃO E

ARRUMAÇÃO

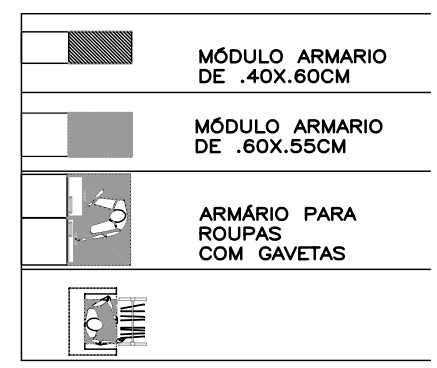

REFEIÇÕES

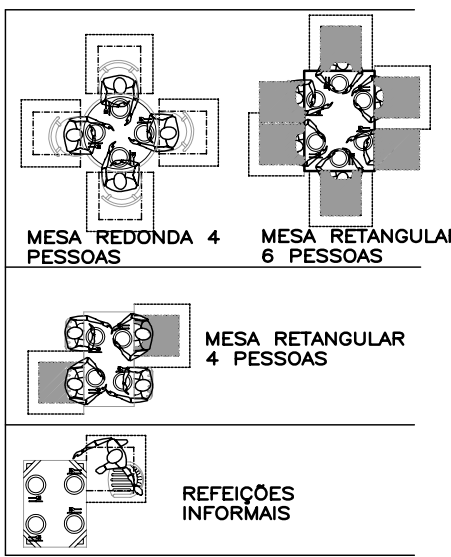


Anexo 8 Resumo Valor de Desempenho Global T2 folha 1 ( PEDRO 1)

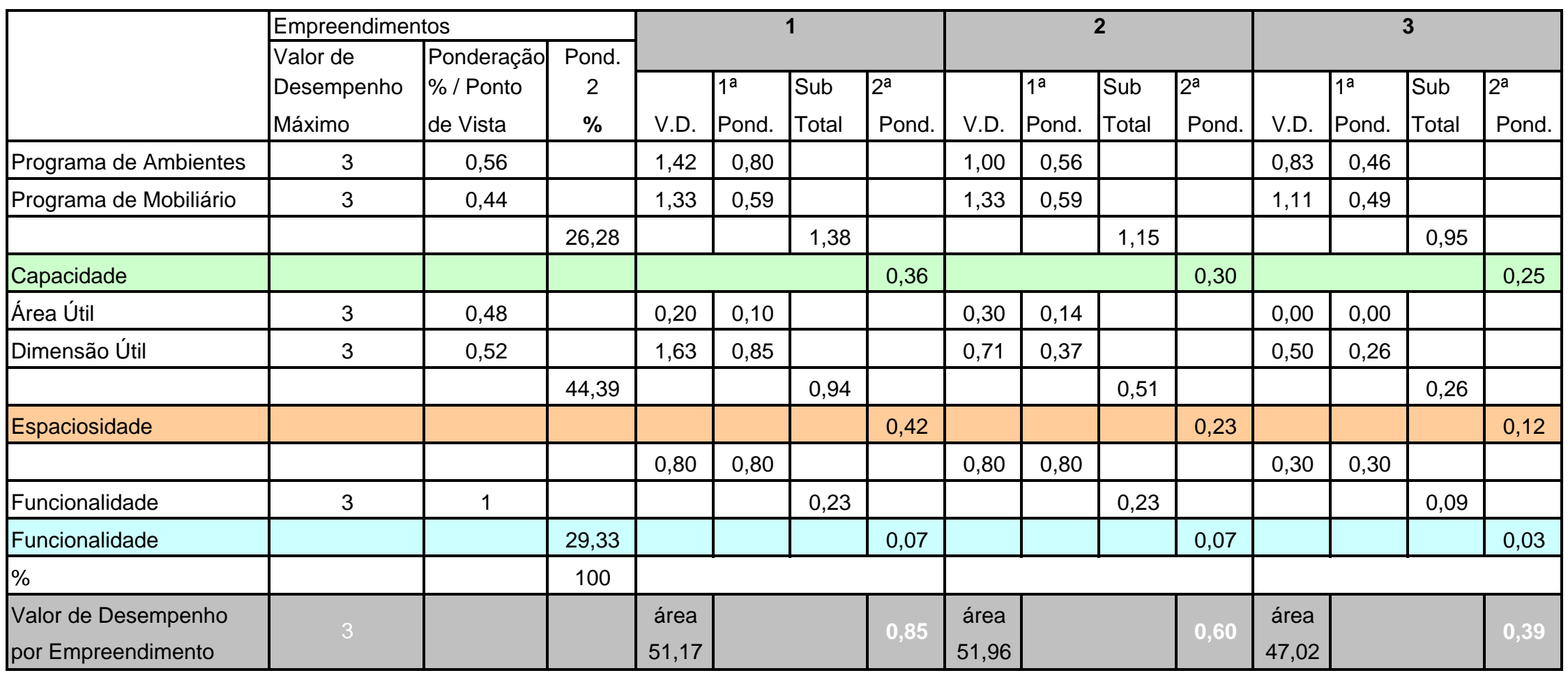

os empreendimentos 4 e 5 estão na folha 47 do capitulo III 
Anexo 8 Resumo Valor de Desempenho Global T3 folha 2 ( PEDRO )

fonte autor

\begin{tabular}{|c|c|c|c|c|c|c|c|c|c|c|c|c|c|c|c|}
\hline & \multicolumn{3}{|c|}{ Empreendimentos } & \multirow{2}{*}{\multicolumn{4}{|c|}{1}} & \multirow{2}{*}{\multicolumn{4}{|c|}{2}} & \multirow{2}{*}{\multicolumn{4}{|c|}{3}} \\
\hline & \multirow{2}{*}{\begin{tabular}{|l} 
Valor de \\
Desempenho \\
Máximo \\
\end{tabular}} & \multirow{2}{*}{\begin{tabular}{|l|} 
Ponderação \\
$\%$ / Ponto \\
de Vista \\
\end{tabular}} & \multirow{2}{*}{$\begin{array}{c}\text { Pond. } \\
2 \\
\% \\
\end{array}$} & & & & & & & & & & & & \\
\hline & & & & V.D. & $\begin{array}{l}1^{\mathrm{a}} \\
\text { Pond. }\end{array}$ & $\begin{array}{l}\text { Sub } \\
\text { Total }\end{array}$ & $\begin{array}{ll}2^{\mathrm{a}} \\
\text { Pond. }\end{array}$ & V.D. & $\begin{array}{l}1^{\mathrm{a}} \\
\text { Pond. }\end{array}$ & $\begin{array}{l}\text { Sub } \\
\text { Total }\end{array}$ & $\begin{array}{l}2^{\mathrm{a}} \\
\text { Pond. }\end{array}$ & V.D. & $\begin{array}{l}1^{\mathrm{a}} \\
\text { Pond. }\end{array}$ & $\begin{array}{l}\text { Sub } \\
\text { Total }\end{array}$ & $\begin{array}{l}2^{\mathrm{a}} \\
\text { Pond. }\end{array}$ \\
\hline Programa de Ambientes & 3 & 0,56 & & 2,25 & 1,26 & & & 1,17 & 0,66 & & & 2,08 & 1,16 & & \\
\hline \multirow[t]{2}{*}{ Programa de Mobiliário } & 3 & 0,44 & & 2,33 & 1,03 & & & 1,44 & 0,63 & & & 1,78 & 0,78 & & \\
\hline & & & 26,28 & & & 2,29 & & & & 1,29 & & & & 1,95 & \\
\hline Capacidade & & & & & & & 0,60 & & & & 0,34 & & & & 0,51 \\
\hline Área Útil & 3 & 0,48 & & 2,00 & 0,96 & & & 0,00 & 0,00 & & & 0,90 & 0,43 & & \\
\hline \multirow[t]{2}{*}{ Dimensão Útil } & 3 & 0,52 & & 3,00 & 1,56 & & & 0,87 & 0,45 & & & 3,00 & 1,56 & & \\
\hline & & & 44,39 & & & 2,52 & & & & 0,45 & & & & 1,99 & \\
\hline \multirow[t]{2}{*}{ Espaciosidade } & & & & & & & 1,12 & & & & 0,20 & & & & 0,88 \\
\hline & & & & 1,00 & 0,00 & & & 0,70 & 0,00 & & & 1,40 & 0,00 & & \\
\hline Funcionalidade & 3 & 1 & & & & 0,29 & & & & 0,21 & & & & 0,41 & \\
\hline Funcionalidade & & & 29,33 & & & & 0,09 & & & & 0,06 & & & & 0,12 \\
\hline$\%$ & & & 100 & & & & & & & & & & & & \\
\hline \multirow{2}{*}{$\begin{array}{l}\text { Valor de Desempenho } \\
\text { por Empreendimento }\end{array}$} & \multirow{2}{*}{3} & & & área & \multirow{2}{*}{\multicolumn{2}{|c|}{$\mathrm{m}^{2}$}} & \multirow{2}{*}{1,81} & área & \multirow{2}{*}{\multicolumn{2}{|c|}{$\mathrm{m}^{2}$}} & \multirow{2}{*}{0,60} & área & \multirow{2}{*}{\multicolumn{2}{|c|}{$\mathrm{m}^{2}$}} & \multirow{2}{*}{1,52} \\
\hline & & & & 108,97 & & & & 56,00 & & & & 90,00 & & & \\
\hline
\end{tabular}


Anexo 8 Resumo Valor de Desempenho Global T3- continuação- folha 3 ( PEDRO )

\begin{tabular}{|c|c|c|c|c|c|c|c|c|c|c|c|}
\hline & \multicolumn{3}{|c|}{ Empreendimentos } & \multirow{2}{*}{\multicolumn{4}{|c|}{4}} & \multirow{2}{*}{\multicolumn{4}{|c|}{5}} \\
\hline & \multirow{2}{*}{$\begin{array}{l}\text { Valor de } \\
\text { Desemp. } \\
\text { Máximo }\end{array}$} & \multirow{2}{*}{\begin{tabular}{|l|} 
Ponderação \\
$\%$ / Ponto \\
de Vista
\end{tabular}} & \multirow{2}{*}{$\begin{array}{l}\text { Pond. } \\
2 \\
\%\end{array}$} & & & & & & & & \\
\hline & & & & V.D. & \begin{tabular}{|l|}
$1^{\mathrm{a}}$ \\
Pond.
\end{tabular} & \begin{tabular}{|l|} 
Sub \\
Total
\end{tabular} & $2^{2^{\mathrm{a}}}$ Pond. & V.D. & $\begin{array}{l}1^{\mathrm{a}} \\
\text { Pond. }\end{array}$ & \begin{tabular}{|l|} 
Sub \\
Total
\end{tabular} & $\begin{array}{l}2^{\mathrm{a}} \\
\text { Pond }\end{array}$ \\
\hline Programa de Ambientes & 3 & \begin{tabular}{|l|}
0,56 \\
\end{tabular} & & 1,42 & 0,80 & & & 1,25 & 0,70 & & \\
\hline \multirow[t]{2}{*}{ Programa de Mobiliário } & 3 & 0,44 & & 1,89 & 0,83 & & & 1,44 & 0,63 & & \\
\hline & & & 26,28 & & & 1,63 & & & & 1,33 & \\
\hline Capacidade & & & & & & & 0,43 & & & & 0,35 \\
\hline Área Útil & 3 & 0,48 & & 0,75 & 0,36 & & & 0,00 & 0,00 & & \\
\hline \multirow[t]{2}{*}{ Dimensão Útil } & 3 & 0,52 & & 2,88 & 1,50 & & & 1,48 & 0,00 & & \\
\hline & & & 44,39 & & & 1,86 & & & & 0,00 & \\
\hline \multirow[t]{2}{*}{ Espaciosidade } & & & & & & & 0,82 & & & & 0,00 \\
\hline & & & & 1,40 & 0,00 & & & 0,50 & 0,00 & & \\
\hline Funcionalidade & 3 & 1 & & & & 0,41 & & & & 0,15 & \\
\hline Funcionalidade & & & 29,33 & & & & 0,12 & & & & 0,04 \\
\hline$\%$ & & & 100 & & & & & & & & \\
\hline \multirow{2}{*}{$\begin{array}{l}\text { Valor de Desempenho } \\
\text { por Empreendimento }\end{array}$} & \multirow{2}{*}{3} & & & área & \multirow{2}{*}{\multicolumn{2}{|c|}{$\mathrm{m}^{2}$}} & \multirow{2}{*}{1,37} & área & \multirow{2}{*}{\multicolumn{2}{|c|}{$\mathrm{m}^{2}$}} & \multirow{2}{*}{0,39} \\
\hline & & & & 92,00 & & & & 61,20 & & & \\
\hline
\end{tabular}


Anexo 8 Resumo Valor de Desempenho Global T4 folha 4 ( PEDRO )

\begin{tabular}{|c|c|c|c|c|c|c|c|c|c|c|c|c|c|c|c|}
\hline & \multicolumn{3}{|c|}{ Empreendimentos } & \multirow{2}{*}{\multicolumn{4}{|c|}{7}} & \multicolumn{4}{|c|}{12} & \multicolumn{4}{|c|}{18} \\
\hline & \multirow{3}{*}{\begin{tabular}{|l} 
Valor de \\
Desemp. \\
Máximo
\end{tabular}} & \multirow{3}{*}{$\begin{array}{l}\text { Pond. } \\
\% \text { /Ponto } \\
\text { de Vista }\end{array}$} & \multirow{3}{*}{$\begin{array}{c}\text { Pond. } \\
2 \\
\%\end{array}$} & & & & & & & & & & & & \\
\hline & & & & & $1^{\mathrm{a}}$ & Sub & $2^{\mathrm{a}}$ & & $1^{\mathrm{a}}$ & Sub & $2^{a}$ & & $1^{a}$ & Sub & $2^{\mathrm{a}}$ \\
\hline & & & & V.D. & Pond. & Total & Pond & V.D. & Pond. & Total & Pond. & V.D. & Pond. & Total & Pond. \\
\hline Programa de Ambientes & 3 & 0,56 & & 2,67 & 1,50 & & & 2,50 & 1,40 & & & 2,25 & 1,26 & & \\
\hline Programa de Mobiliário & 3 & 0,44 & & 2,56 & 1,13 & & & 2,67 & 1,17 & & & 2,67 & 1,17 & & \\
\hline \multicolumn{16}{|l|}{ Capacidade } \\
\hline & & & 26,28 & & & 2,62 & 0,69 & & & 2,57 & 0,68 & & & 2,43 & 0,64 \\
\hline Área Útil & 3 & 0,48 & & 1,85 & 0,89 & & & 1,83 & 0,88 & & & 1,33 & 0,64 & & \\
\hline Dimensão Útil & 3 & 0,52 & & 3,57 & 1,86 & & & 2,72 & 1,41 & & & 3,17 & 1,65 & & \\
\hline \multicolumn{16}{|l|}{ Espaciosidade } \\
\hline & & & 44,39 & & & 2,74 & 1,22 & & & 2,29 & 1,02 & & & 2,29 & 1,02 \\
\hline Funcionalidade & 3 & 1 & & 1,40 & 1,40 & & & 1,60 & & & & 1,50 & & & \\
\hline Funcionalidade & & & 29,33 & & & 1,40 & 0,41 & & & 0,47 & 0,14 & & & 0,44 & 0,13 \\
\hline & & & & & & & & & & & & & & & \\
\hline Valor de Desempenho. & 3 & & 100 & & & & 2,32 & & & & 1,83 & & & & 1,7 \\
\hline
\end{tabular}


Anexo 8 Resumo Valor de Desempenho Global T4 folha 5 ( PEDRO )

\begin{tabular}{|c|c|c|c|c|c|c|c|c|c|c|c|c|c|c|c|}
\hline & \multicolumn{3}{|c|}{ Empreendimentos } & \multirow{2}{*}{\multicolumn{4}{|c|}{19}} & \multirow{2}{*}{\multicolumn{4}{|c|}{49}} & \multirow{2}{*}{\multicolumn{4}{|c|}{113}} \\
\hline & \multirow{2}{*}{$\begin{array}{l}\text { Valor de } \\
\text { Desemp. } \\
\text { Máximo }\end{array}$} & \multirow{2}{*}{\begin{tabular}{|l|} 
Pond. \\
\% / Ponto \\
de Vista
\end{tabular}} & \multirow{2}{*}{$\begin{array}{c}\text { Pond. } \\
2 \\
\% \\
\end{array}$} & & & & & & & & & & & & \\
\hline & & & & V.D. & $\begin{array}{l}1^{\mathrm{a}} \\
\text { Pond. }\end{array}$ & $\begin{array}{l}\text { Sub } \\
\text { Total }\end{array}$ & $\begin{array}{l}2^{\mathrm{a}} \\
\text { Pond. }\end{array}$ & V.D. & $\begin{array}{l}1^{\mathrm{a}} \\
\text { Pond. }\end{array}$ & $\begin{array}{l}\text { Sub } \\
\text { Total }\end{array}$ & $\begin{array}{l}2^{\mathrm{a}} \\
\text { Pond. }\end{array}$ & V.D. & $\begin{array}{l}1^{\mathrm{a}} \\
\text { Pond. }\end{array}$ & \begin{tabular}{|l|} 
Sub \\
Total
\end{tabular} & $\begin{array}{l}2^{\mathrm{a}} \\
\text { Pond. }\end{array}$ \\
\hline Programa de Ambientes & 3 & 0,56 & & 1,50 & 0,84 & & & 1,83 & 1,02 & & & 2,58 & 1,44 & & \\
\hline Programa de Mobiliário & 3 & 0,44 & & 1,78 & 0,78 & & & 2,22 & 0,98 & & & 2,89 & 1,27 & & \\
\hline \multicolumn{16}{|l|}{ Capacidade } \\
\hline & & & 26,28 & & & 1,62 & 0,43 & & & 2,00 & 0,53 & & & 2,72 & 0,71 \\
\hline Área Útil & 3 & 0,48 & & 0,51 & 0,24 & & & 1,42 & 0,68 & & & 1,84 & 0,88 & & \\
\hline Dimensão Útil & 3 & 0,52 & & 2,30 & 1,20 & & & 2,40 & 1,25 & & & 2,74 & 1,42 & & \\
\hline \multicolumn{16}{|l|}{ Espaciosidade } \\
\hline & & & 44,39 & & & 1,44 & 0,64 & & & 1,93 & 0,86 & & & 2,31 & 1,02 \\
\hline Funcionalidade & 3 & 1 & & 0,70 & & & & 1,00 & & & & 1,20 & & & \\
\hline Funcionalidade & & & 29,33 & & & 0,21 & 0,06 & & & 0,29 & 0,09 & & & 0,35 & 0,10 \\
\hline & & & & & & & & & & & & & & & \\
\hline & & & & & & & & & & & & & & & \\
\hline Valor de Desempenho & 3 & & 100 & & & & 1,13 & & & & 1,47 & & & & 1,84 \\
\hline
\end{tabular}


Anexo 8 Resumo Valor de Desempenho Global T4 folha 6 ( PEDRO )

\begin{tabular}{|c|c|c|c|c|c|c|c|c|c|c|c|c|c|c|c|c|c|c|c|}
\hline & \multicolumn{3}{|c|}{ Empreendimentos } & \multirow{2}{*}{\multicolumn{4}{|c|}{165}} & \multirow{2}{*}{\multicolumn{4}{|c|}{166}} & \multirow{2}{*}{\multicolumn{4}{|c|}{167}} & \multicolumn{4}{|c|}{168} \\
\hline & \multirow{3}{*}{$\begin{array}{l}\text { Valor de } \\
\text { Desemp. } \\
\text { Máximo }\end{array}$} & \multirow{3}{*}{\begin{tabular}{|l|} 
Pond. \\
$\%$ / Ponto \\
de Vista
\end{tabular}} & \multirow{3}{*}{$\begin{array}{l}\text { Pond. } \\
2 \\
\%\end{array}$} & & & & & & & & & & & & & & & & \\
\hline & & & & & $1^{a}$ & Sub & $2^{a}$ & & $1^{a}$ & Sub & $2^{\mathrm{a}}$ & & $1^{a}$ & Sub & $2^{\mathrm{a}}$ & & $1^{a}$ & Sub & $2^{\mathrm{a}}$ \\
\hline & & & & V.D. & Pond. & Total & Pond. & V.D. & Pond. & Total & Pond. & V.D. & Pond. & Total & Pond. & V.D. & Pond. & Total & Pond. \\
\hline Programa de Ambientes & 3 & 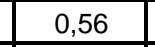 & & 1,83 & 1,02 & & & 1,75 & 0,98 & & & 2,17 & 1,22 & & & 2,25 & 1,26 & & \\
\hline Programa de Mobiliário & 3 & 0,44 & & 2,33 & 1,03 & & & 2,44 & 1,07 & & & 2,44 & 1,07 & & & 2,22 & 0,98 & & \\
\hline Capacidade & & & & & & & & & & & & & & & & & & & \\
\hline & & & 26,28 & & & 2,05 & 0,54 & & & 2,05 & 0,54 & & & 2,29 & 0,60 & & & 2,24 & 0,59 \\
\hline Área Útil & 3 & 0,48 & & 1,74 & 0,84 & & & 1,83 & 0,88 & & & 1,84 & 0,88 & & & 3,00 & 1,44 & & \\
\hline Dimensão Útil & 3 & 0,52 & & 3,36 & 1,75 & & & 3,41 & 1,77 & & & 2,85 & 1,48 & & & 3,41 & 1,77 & & \\
\hline Espaciosidade & & & & & & & & & & & & & & & & & & & \\
\hline & & & 44,39 & & & 2,58 & 1,15 & & & 2,65 & 1,18 & & & 2,37 & 1,05 & & & 3,21 & 1,43 \\
\hline Funcionalidade & 3 & 1 & & 0,90 & & & & 0,90 & & & & 1,60 & & & & 1,00 & & & \\
\hline Funcionalidade & & & 29,33 & & & 0,26 & 0,08 & & & 0,26 & 0,08 & & & 0,47 & 0,14 & & & 0,29 & 0,09 \\
\hline & & & & & & & & & & & & & & & & & & & \\
\hline & & & & & & & & & & & & & & & & & & & \\
\hline Valor de Desemp. & 3 & & 100 & & & & 1,76 & & & & 1,79 & & & & 1,79 & & & & 2,10 \\
\hline
\end{tabular}




\title{
Empreendimento 19 T4 \\ ANÁLISE DE PLANTA \\ Método Gráfico de A. Klein e Ciclo Familiar de H. Deilmann e outros
}

\begin{abstract}
Alexandre Kenchian, ak.arq@cmg.com.br
Pablo Arturo Céspedes Jimenez, parturo69@hotmail.com

FAUUSP - Curso de Pós Graduação em Arquitetura
\end{abstract}

\section{INTRODUÇÃO}

Com base em um determinado jogo de plantas de um estudo para projeto de edifício residencial, com duas propostas de organização espacial ( $1^{\circ}$ estudo e planta definitiva), foram feitas análises, como Aplicação dos Métodos e Técnicas de Dimensionamento e Avaliação Dimensional, a partir dos métodos de A. Klein (Método Gráfico), e H. Deilmann e outros (Ciclo Familiar).

\section{APRESENTAÇÃO DAS PLANTAS}

Os estudos de projeto apresentados são de autoria da Arq. Cláudia Lapetina, e referem-se a um edifício residencial, de apartamentos com ambientes de sala de estar e jantar conjugados, varanda, cozinha e área de serviço, w.c. de serviço, e quatro dormitórios, sendo um deles suíte, com banheiro privativo, além de outro banheiro social. São apresentados dois estudos, sendo uma $1^{\circ}$ proposta de área útil de 86,71 m², e outra, definitiva, com área útil de 90,00 m².

A seguir são apresentados figuras com os dois estudos de planta.

\section{FIGURA 1 - Estudos de projeto}
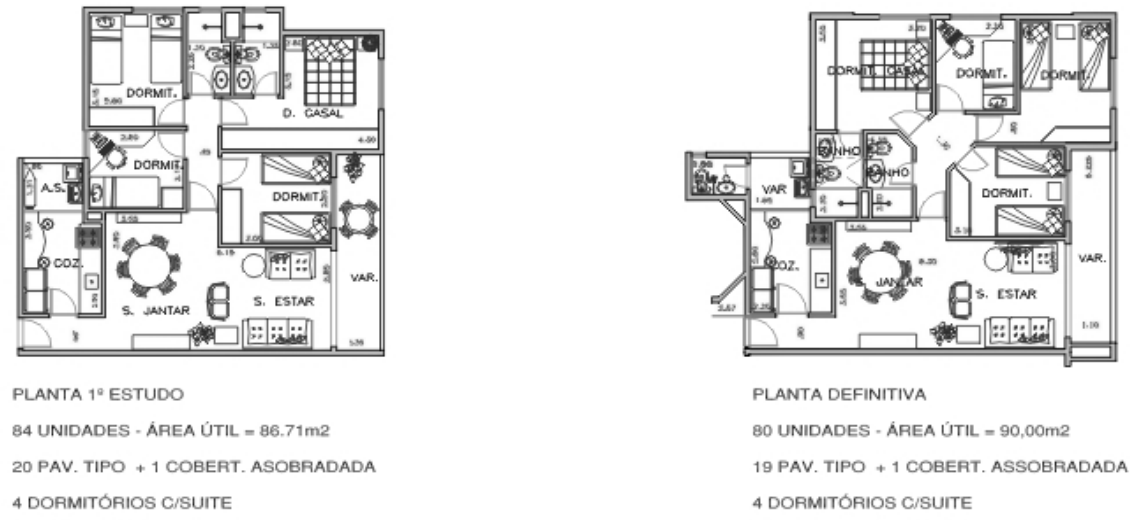

Universidade de São Paulo Faculdade de Arquitetura e Urbanismo Curso de Pós Graduação 


\section{MÉTODO GRÁFICO DE A. KLEIN}

O estudo de projeto apresentado foi analisado, dentro do Método Gráfico de A. Klein, baseandose nos seguintes elementos de análise:

- organização espacial

- circulação

- disposição do mobiliário

- relações entre os elementos de planta

\section{Análise da Organização Espacial}

A partir da Organização Espacial, podemos caracterizar as tipologias apresentadas como sendo ambas de uma habitação usual, com corredor e programa definido já descrito na introdução a este trabalho, que permite até 6 camas para 7 pessoas (1 cama de casal), distribuídos em 4 dormitórios.

\section{FIGURA 2 - Organização Espacial}

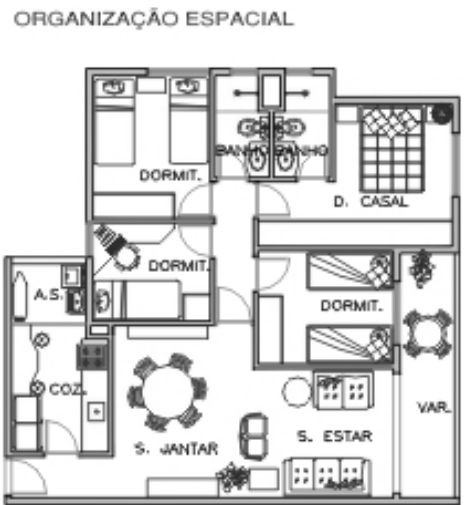

PLANTA $1^{\circ}$ ESTUDO

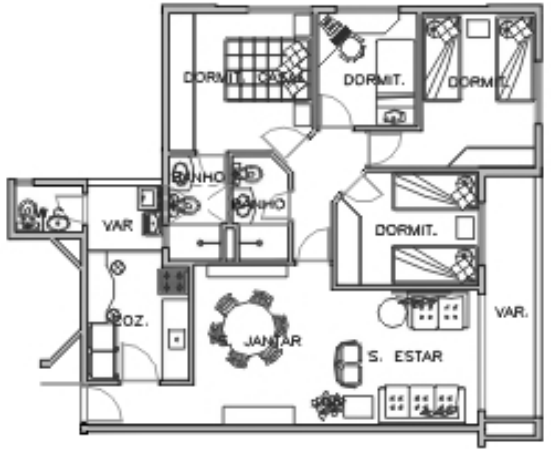

PLANTA DEFINITIVA

Podemos ainda apontar alguns aspectos, para ambos os estudos:

- Zonas de uso bem definidas, com ambientes isolados para as atividades íntima (dormir, estudar, lavar-se), social (estar e comer), e de serviço (cozinhar, limpar).

- Planta elaborada com base na disposição e espacialidade dos cômodos, com sua subdivisão em duas áreas principais: zonas de dia e zona de noite.

- Flexibilização dos espaços, com possibilidade de transformação de um dormitório, contíguo à sala de estar, revertendo-o para um ambiente na zona social (aumento da sala ou escritório); ou do dormitório menor em pequeno escritório ou closet para o dormitório do casal (na planta definitiva).

- Localização e dimensões do terraço, largo e estreito, de maneira a permitir acesso tanto pela sala, como por um dos dormitórios. A amplitude do terraço e da esquadria de acesso a ele permite uma boa iluminação e ventilação para a sala e o dormitório.

Como diferencial entre os estudos, do definitivo em relação ao $1^{\circ}$ estudo, temos um pequeno aumento da área útil, e a inserção de um w.c. de serviço. 
ZONAS DE UTILIZAÇĀ̄O

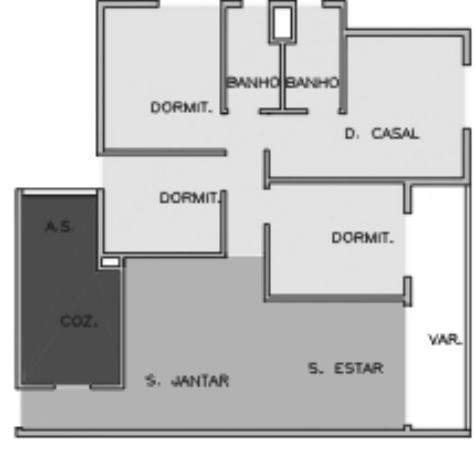

PLANTA $1^{\circ}$ ESTUDO

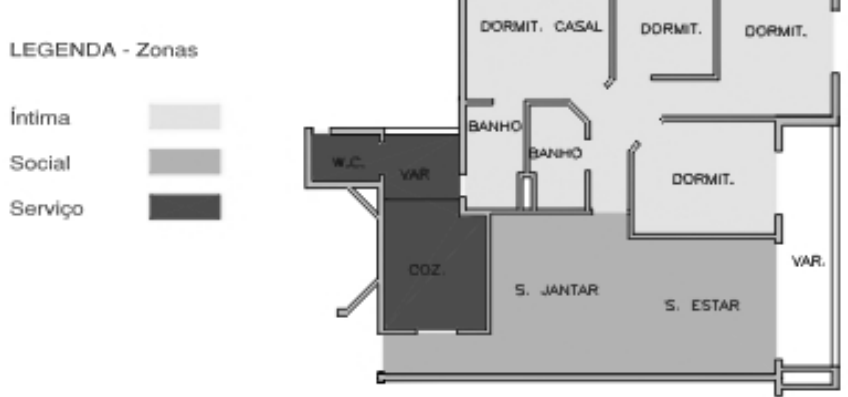

PLANTA DEFINITIVA

\section{Análise da Circulação}

Nas plantas apresentadas podemos verificar que para ambos os casos a circulação entre os ambientes permite que as três zonas de utilização possam se desenvolver sem interferência, sem que haja algum tipo de cruzamento.

As áreas de circulação entre os dormitórios e os banheiros estão bem definidas e concentradas dentro da zona íntima. Ainda, com a solução da suíte, o acesso do dormitório do casal ao banheiro e mais rápido e mais reservado.

FIGURA 4 - Circulação entre os Ambientes

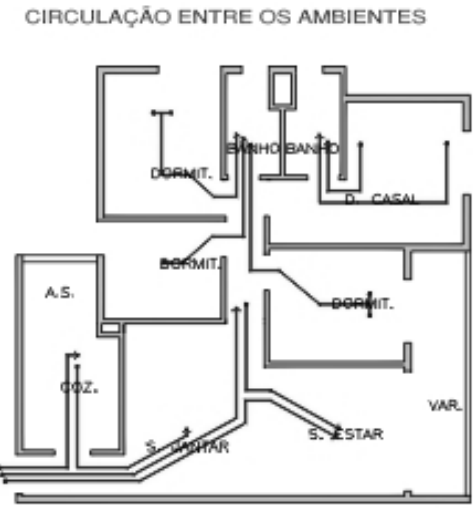

PLANTA $1^{2}$ ESTUDO

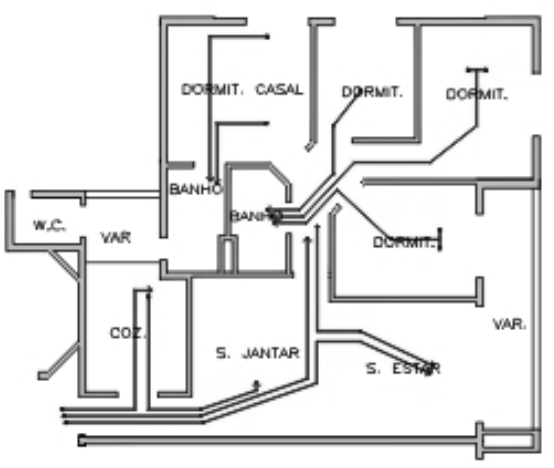

PLANTA DEFINITIVA

Por outro lado, a circulação para a zona íntima e entre as zonas social e de serviço é feita por um vestíbulo de entrada e no meio do ambiente da sala, dividindo-o em área de jantar e estar; esta circulação tem um caminho relativamente sinuoso entre os móveis, o que pode também ser verificado pela área de circulação necessária a este tipo de acesso. 
FIGURA 5 - Áreas de Circulação

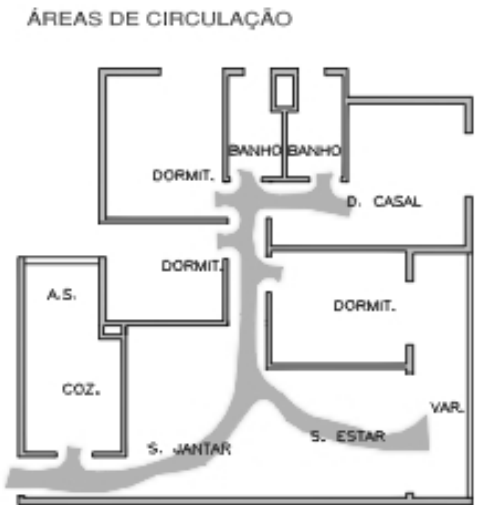

PLANTA $1^{\circ}$ ESTUDO

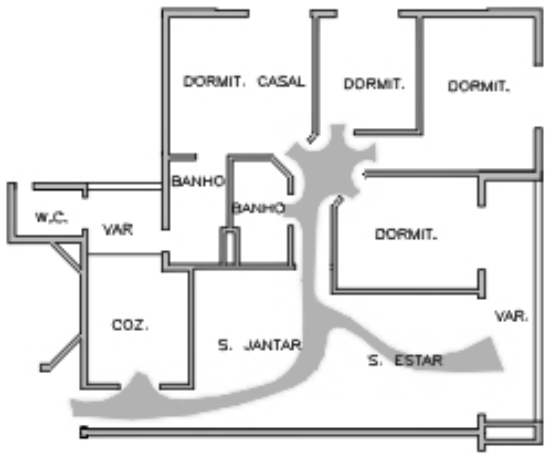

PLANTA DEFINITIVA

Em ambos os estudos, as áreas de circulação nas zonas social e de serviço são similares, apresentando as mesmas características, com trajeto relativamente complicado até o terraço, com uma faixa estreita e sinuosa, incomodando os que estão sentados.

Toda a área de vestíbulo é zona de passagem estreita, sem que se possa dispor nele algum mobiliário.

Na zona íntima, apresenta-se uma diferença entre o $1^{\circ}$ estudo e o definitivo, onde este último tem superfície e organização mais concentrada e menos sinuosa, em comparação ao outro.

\section{Análise da Disposição do Mobiliário}

Nas plantas estudadas, apesar das manchas mostrarem-se diferentes, a disposição do mobiliário apresenta as mesmas características. A diferença visual é justificada pela diferença na disposição dos ambientes e organização espacial.

Dentro de cada ambiente, usa-se dos mesmos critérios, onde a colocação dos mobiliários e equipamentos é concentrada, permitindo o acesso às aberturas dos ambientes, sem interferência de mobiliários, com exceção para alguns dormitórios, com a cama junto à esquadria.

$\mathrm{Na}$ sala, alguns móveis ficam dispostos no meio do ambiente, mas com a clara intenção de formalizar a divisão funcional do espaço, em estar e jantar.

O uso de armários embutidos e a disposição dos móveis altos junto às paredes e afastados das aberturas, evitam o fracionamento dos espaços e da circulação, permitem boa iluminação e evitam cantos escuros e formação de sombras nos ambientes. 
FIGURA 6 - Disposição do Mobiliário

DISPOSIÇĀO DOS MOBILIÁRIOS

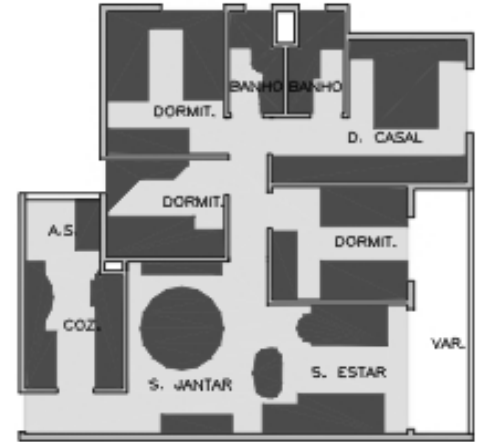

PLANTA $1^{2}$ ESTUDO
LEGENDA - Mobiliário

Móveis

Vazios

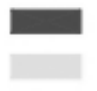

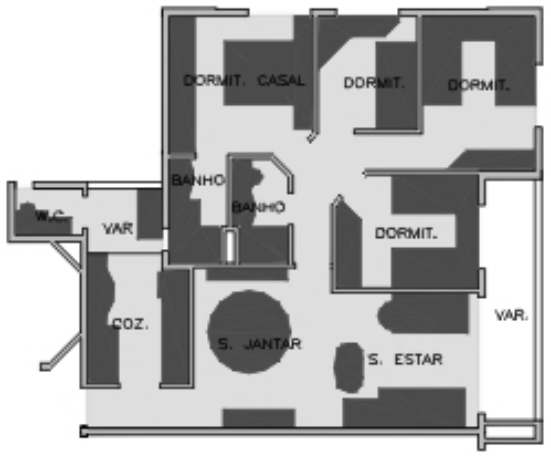

PLANTA DEFINITIVA

\section{Análise das Relações entre os Elementos de Planta}

A partir do estudo da interrelação entre os cômodos, podemos analisar os usos e acessos dos estudos de projeto apresentados.

\section{Interrelação entre o dormitório principal e os outros dormitórios.}

Em ambos os casos a relação entre os dormitórios tem como conexão um hall de distribuição central e de pequena superfície, permitindo uma circulação sem cruzamentos e por caminhos breves e diretos. Ainda assim, o $1^{\circ}$ estudo apresenta caminhos um pouco maiores em relação ao definitivo.

Por outro lado, a disposição da cama de casal no estudo definitivo propõe um caminho maior para um entre o casal, em relação ao $1^{\circ}$ estudo; enquanto que o outro do casal tem trajeto bastante rápido e direto.

\section{FIGURA 7 - Dormitório Principal e os Outros Dormitórios}

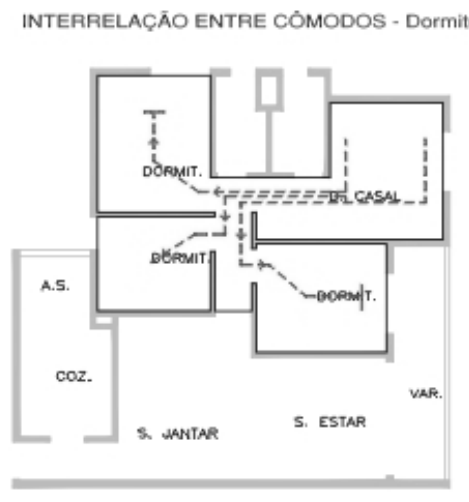

PLANTA $1^{\circ}$ ESTUDO

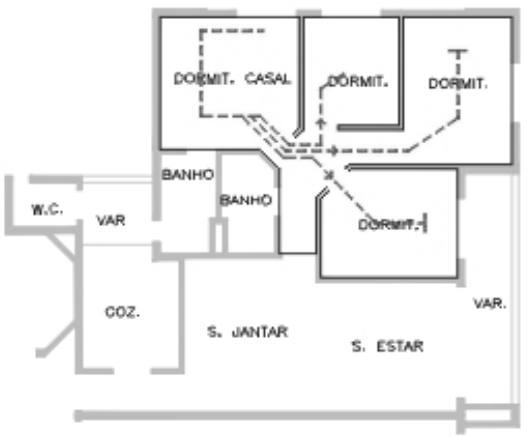

PLANTA DEFINITIVA

\section{Interrelação entre o dormitório principal e o banheiro}

Em ambos os casos, a interrelação entre o dormitório principal e o banheiro tem, com a solução da suíte, conexão e acesso bastante facilitado do dormitório do casal ao banheiro, sendo mais rápido e mais reservado, sem cruzamentos e concentradas dentro da zona íntima. Mesmo a disposição da cama de casal não altera o acesso ao banheiro, sendo rápido e direto. 
No $1^{\circ}$ estudo, a área de acesso ao banheiro, dentro do dormitório, permite a colocação de armário embutido, com melhor aproveitamento de espaços, o que não é possível no definitivo.

\section{FIGURA 8 - Dormitório Principal e Banheiro}

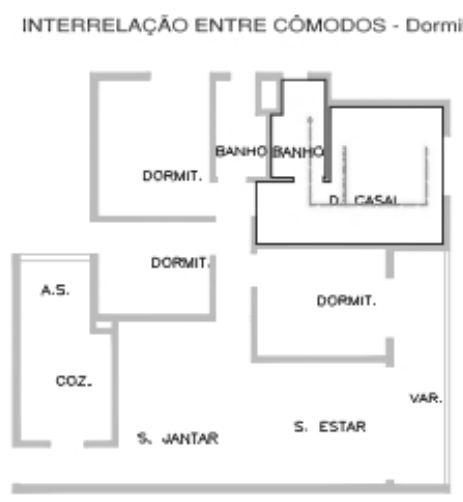

PLANTA $1^{\circ}$ ESTUDO

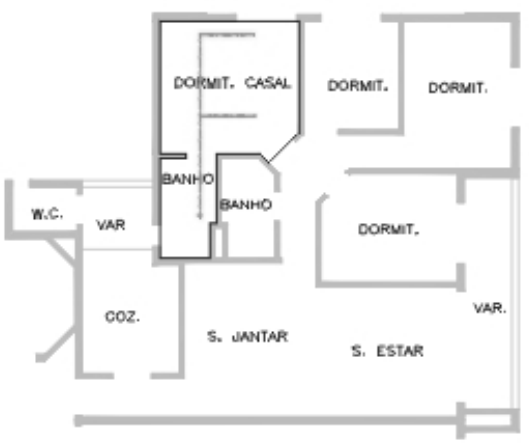

PLANTA DEFINITIVA

\section{Interrelação entre os outros dormitórios e o banheiro}

No estudo definitivo, a localização do banheiro social, mais central, permite uma conexão mais rápida e direta, e de maneira mais equilibrada para todos os outros três dormitórios, em relação ao $1^{\circ}$ estudo. Mesmo assim, os caminhos apresentam certa complexidade. Ainda, o banheiro social está mais próximo ao acesso à zona social, que também pode fazer uso deste.

\section{FIGURA 9 - Outros Dormitórios e Banheiro}

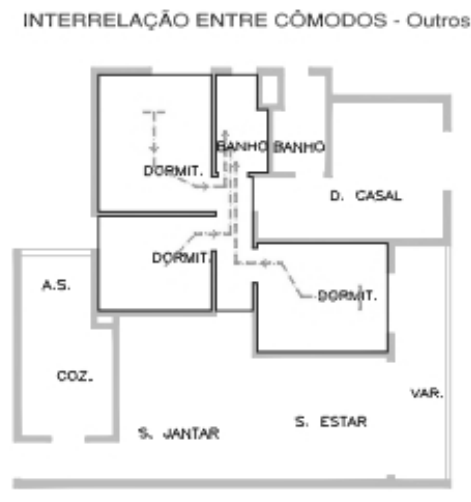

PLANTA $1^{\circ}$ ESTUDO

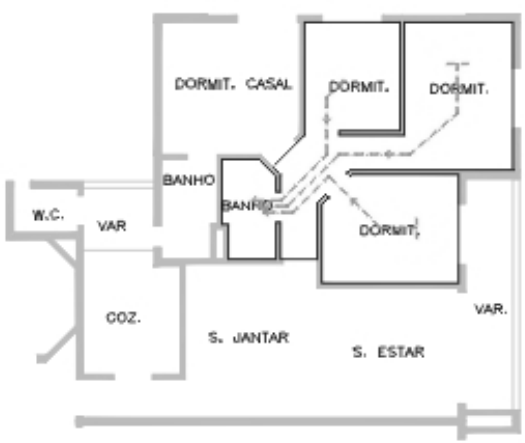

PLANTA DEFINITIVA

\section{Interrelação entre a sala e o dormitório principal}

Em ambos os casos o dormitório do casal apresenta localização bastante isolada em relação à zona social. Assim, o acesso ao dormitório é feito por caminho longo, o que não vem a ser uma desvantagem, já que se privilegia o isolamento da área íntima.

Esse critério pode servir na interrelação entre toda a zona íntima e a zona social. 
FIGURA 10 - Sala e Dormitório Principal

INTERRELAÇÃO ENTRE CÓMODOS - Sala e Dormitório Principal

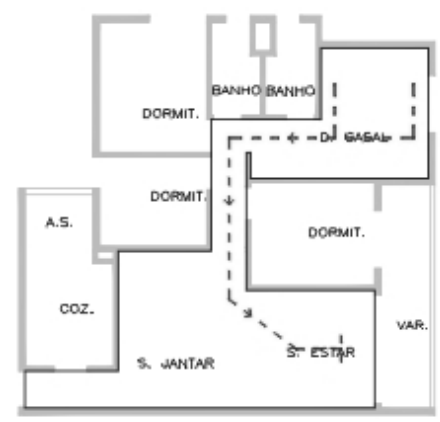

PLANTA $1^{\circ}$ ESTUDO

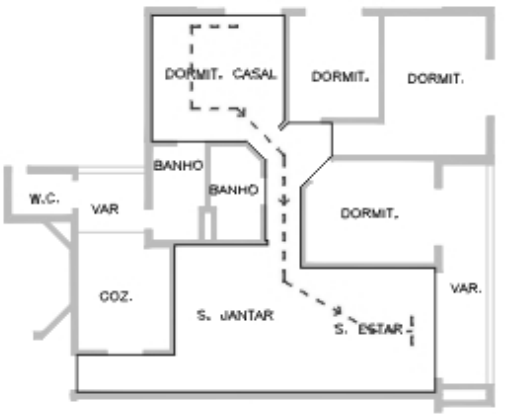

PLANTA DEFINITIVA

\section{Interrelação entre as salas e a cozinha}

Em ambos os casos a disposição desses ambientes é a mesma, cabendo a mesma análise.

O acesso entre a cozinha e a sala de jantar não é ideal, apesar de rápido e direto, onde apresenta giro de $90^{\circ}$, e passa pelo vestíbulo de entrada em penumbra, onde aí pode haver cruzamento com o acesso de entrada à habitação.

Já o acesso até a sala de estar apresenta-se longo e tortuoso, apesar de menos prioritário, devendo-se passar pela sala de jantar e desviar do mobiliário existente.

\section{FIGURA 11 - Salas e Cozinha}

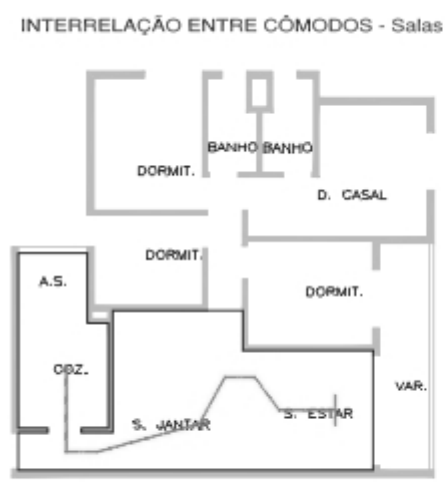

PLANTA $1^{\circ}$ ESTUDO

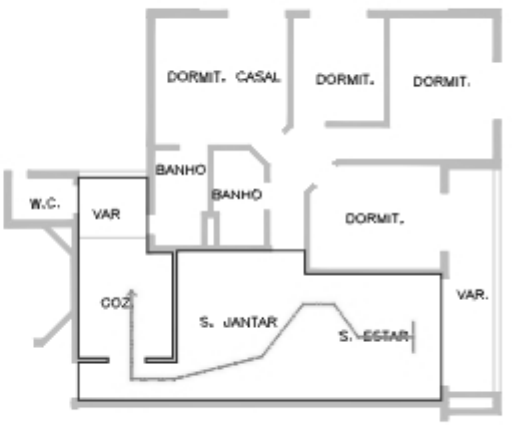

PLANTA DEFINITIVA

\section{Interrelação entre a circulação de entrada e a cozinha}

Em ambos os casos a disposição desses ambientes é a mesma, cabendo a mesma análise.

O acesso entre a entrada da habitação e a cozinha é rápido e direto, apesar do giro de $90^{\circ}$ e da penumbra no vestíbulo de entrada. Também aí pode haver cruzamento com o acesso entre cozinha e salas. 
FIGURA 12 - Circulação de Entrada e Cozinha

INTERRELAÇÃO ENTRE CÓMODOS - Circulação de Entrada e Cozinha

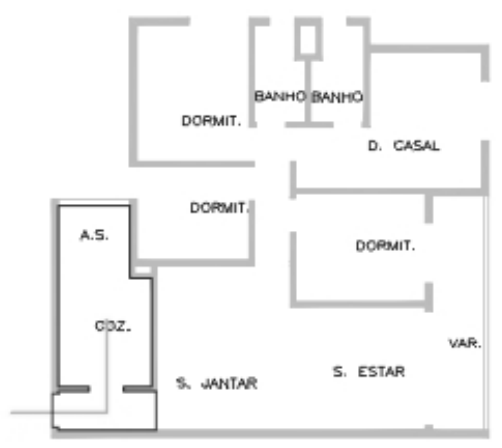

PLANTA $1^{\circ}$ ESTUDO

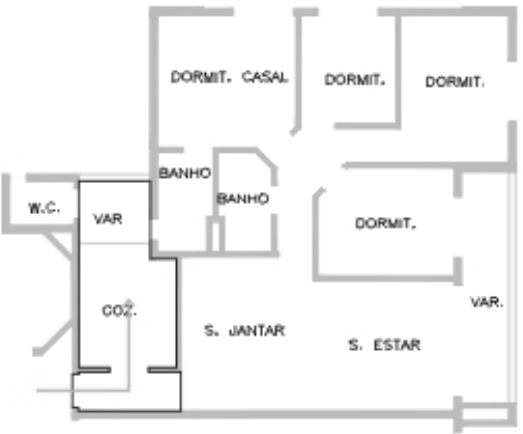

PLANTA DEFINITIVA

Interrelação entre o dormitório principal e a cozinha

Em ambos os casos o dormitório do casal apresenta localização bastante isolada também em relação à zona de serviço. Assim, o acesso aos dormitórios pela cozinha é feito por caminho longo e tortuoso, passando por toda a zona social, tornando-se uma desvantagem quando da perturbação que pode causar às pessoas nas salas.

\section{FIGURA 13 - Dormitório Principal e Cozinha}

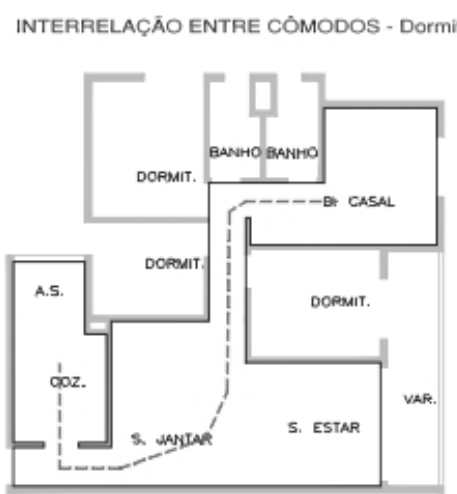

PLANTA $1^{\circ}$ ESTUDO

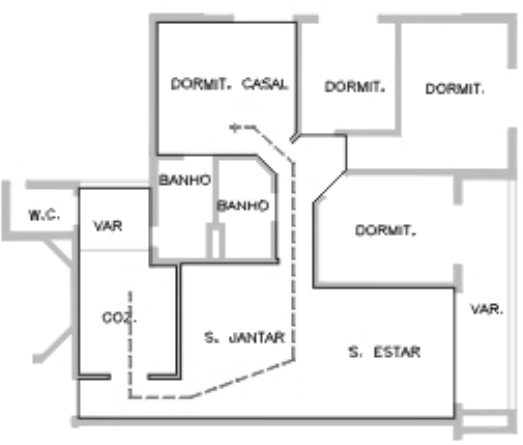

PLANTA DEFINITIVA

\section{Comparação entre as áreas de superfície habitável e construída}

Segundo o Método de Léo Adler, introduzido por Klein em seu estudo, ao comparar-se as áreas de superfície habitada e construída para os estudos de projeto apresentados, podemos analisar e comparar os valores obtidos, conforme tabela que segue: 
TABELA 1

Comparação entre as áreas de superfície habitável e construída, para os tipos apresentados, segundo o método de Leo Adler.

\begin{tabular}{|c|c|c|c|c|c|}
\hline $1^{\circ}$ Estudo $\left(86,710 m^{2}\right)$ & $\bar{m}^{2}$ & $\%$ & Definitivo $\left(90,000 \mathrm{~m}^{2}\right)$ & $\mathrm{m}^{2}$ & $\%$ \\
\hline Total & 77,000 & 88,80 & Total & 79,642 & 88,49 \\
\hline Paredes & 9,710 & 11,20 & Paredes & 10,358 & 11,51 \\
\hline $\begin{array}{l}\text { Dependências secundárias } \\
\text { cozinha, banheiro, } \\
\text { circulação }\end{array}$ & 17,947 & 20,70 & $\begin{array}{l}\text { Dependências secundárias } \\
\text { cozinha, banheiro, circulação }\end{array}$ & 20,967 & 23,30 \\
\hline $\begin{array}{l}\text { Salas de estar e de jantar e } \\
\text { varanda }\end{array}$ & 27,096 & \multirow[t]{2}{*}{68,10} & $\begin{array}{l}\text { Salas de estar e de jantar e } \\
\text { varanda }\end{array}$ & 26,436 & \multirow[t]{2}{*}{65,19} \\
\hline Dormitórios & 31,957 & & Dormitórios & 32,239 & \\
\hline
\end{tabular}

Nos valores apresentados, podemos observar que, apesar de um aumento da área construída para o estudo definitivo em relação ao $1^{\circ}$ estudo, em números percentuais, esses valores não se alteraram para mais.

Pelo contrário, por conta da inserção de um w.c. junto à área de serviço, as dependências secundárias apresentam porcentagens maiores em relação às áreas habitáveis, comparando-se o estudo definitivo em relação ao $1^{\circ}$ estudo.

Quanto às áreas úteis e de parede, os valores percentuais não alteram significativamente nos dois estudos de projeto.

\section{CICLO FAMILIAR DE H. DEILMANN E OUTROS}

\section{Classificação quanto ao Tipo Familiar}

Considerando o mesmo modelo familiar adotada por Deilmann para este estudo de projeto, podemos classificá-lo entre um dos quatro tipos familiares. Deilmann adotou como modelo, uma família média de 4 pessoas: pai, mãe, dois filhos; e apresentou quatro classificações de tipos familiares: o Tipo Familiar I, onde os filhos pequenos têm idades de até 1,3 anos e 6 anos; o Tipo Familiar II, onde os filhos pré-adolescentes têm idades de até 6 e 10 anos; o Tipo Familiar III, onde os filhos adolescentes têm idades entre 10 e 14 anos; e o Tipo Familiar IV, onde os filhos já quase adultos têm idades acima dos 14 anos;

Não podemos classificar estas plantas, de organização espacial bastante semelhante, em atendimento ao Tipo Familiar I, onde as condições que apresentam o grupo de idade correspondente aos filhos pequenos caracterizam-se por uma necessidade grande de auxílio e contato, a serem atendidos pela mãe, onde os dois tipos de atividade infantil, de descanso e lazer, requerem acesso visual, acústico e físico. As plantas apresentam ambientes de descanso e lazer isolados pela circulação dos locais de atividade doméstica da mãe, quer seja na cozinha, ou nas salas de estar e jantar.

Ainda, para o Tipo Familiar II, apesar do processo de individualização dos filhos, o de idade menor necessita de contato maior com a mãe para brincar. Já o filho maior, para estudar e relacionarse com amigos, necessita de espaço próprio, sendo que ele começa a ampliar o círculo de relações pessoais, para além da mãe, como em escolas. Assim, os estudos de projeto atendem parcialmente 
às necessidades do Tipo Familiar II, pelas suas características de isolamento entre as áreas de descanso e lazer infantil com as áreas de atividades domésticas da mãe.

Dentro dessa classificação, em análise às plantas, estas têm características que podem melhor atender aos Tipos Familiar III e IV, onde os filhos, adolescentes e quase adultos não mais necessitam de ajuda vinda do contato dos pais, ao contrário, necessitam de certas condições especiais para realizar boa parte das atividades e modos de comportamento tanto individuais, como comunicativos, dentro dos ambientes da casa.

Assim, as características das plantas, com os ambientes isolados e distintos para cada membro da família, permitem uma indispensável diferenciação espacial das áreas das atividades, com maior capacidade de comunicação e independência, aumentando o número de atividades possíveis.

\section{Classificação quanto ao Tipo de Utilização}

Quanto ao Tipo de Utilização proposto por Deilmann, a partir dos tipos familiares caracterizados, temos uma classificação de três tipos de atividades a serem bem realizadas em: 1). sentido comunicativo, no Tipo de Utilização A, próprio ao Tipo Familiar I; 2). sentido individual, no Tipo de Utilização C, próprio ao Tipo Familiar IV; e 3). intermediariamente, nos Tipo de Utilização AB e BC, correspondentes à demanda dos Tipos Familiares II e III.

Os estudos de projeto apresentados, considerando os tipos familiares nos quais mais são adequados, tendem a serem classificados intermediariamente nos Tipos de Utilização $A B$ e $B C$, porém com características muito próximas do Tipo de Utilização C, de sentido individual.

\section{Classificação quanto ao Tipo de Planta}

Os Tipos de Planta servem para facilitar a análise e classificação de exemplos, determinada por duas características: 1). a disposição dos ambientes e dos acessos; e 2). o uso proposto e possível dos ambientes.

O objetivo desta classificação é descrever sistematicamente as conseqüências destas duas características a fim de comparar exemplos e tipificar as possíveis decisões de projeto.

Por meio de diagramas, utilizando-se dos critérios de coordenação e distribuição do espaço arquitetônico, estes tipos de planta têm funcionalmente seus os espaços/ambientes representados conforme a figura:

\section{FIGURA 14 - Diagrama de Funções}

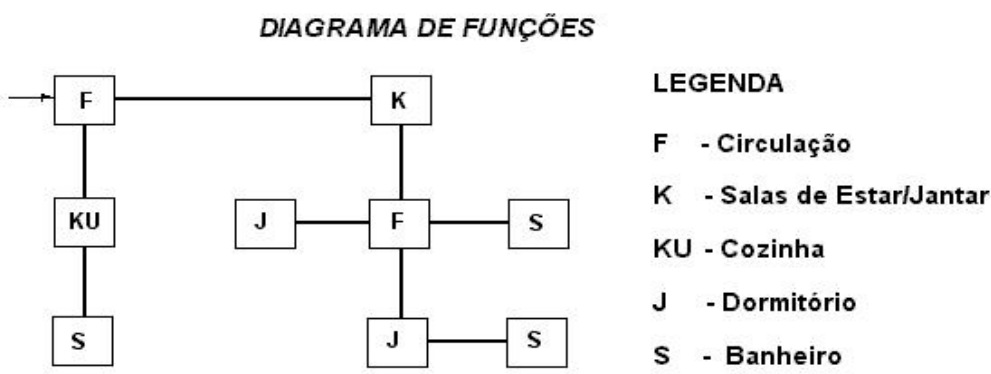

Dentro dos exemplos apresentados por Deilmann para os Tipos de Planta, os que podem ser associados ao estudo de projeto proposto são aqueles indicados nos Grupos 4 e 5 que têm características similares, como:

- Plantas caracterizadas por uma separação quase que absoluta entre as zonas social e íntima.

- O tipo de acesso à zona íntima por passagem neutra, permitindo certo isolamento na utilização dos ambientes.

- Pequena suscetibilidade a perturbações, pois tem dormitório anexo à zona social. 
- O uso dos ambientes é muito rígido e mais específico.

Também tem algumas características do Grupo 8, como por exemplo, na inserção dos banheiros isoladamente para a suíte (ou, o dormitório principal), eliminando possíveis perturbações. Assim como no acesso à zona íntima, que se faz através do ambiente de estar, podendo provocar perturbações. Com isso, a flexibilidade de utilização das áreas é tão limitada que só se justifica pela redução substancial das áreas de acesso. 
